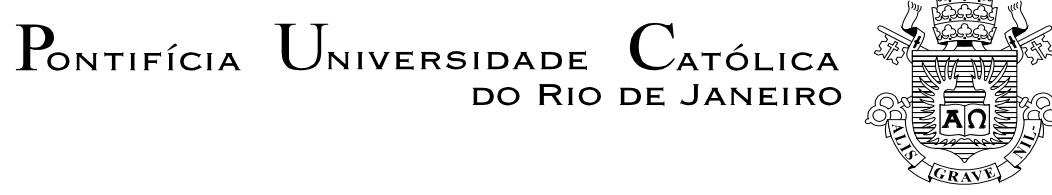

Rosanne Pauzeiro Pousada

\title{
Tradução e internacionalização da literatura brasileira: O papel da Fundação Biblioteca Nacional
}

\begin{abstract}
Dissertação de Mestrado
Dissertação apresentada como requisito parcial para obtenção do grau de Mestre em Letras/Estudos da Linguagem pelo Programa de Pósgraduação em Estudos da Linguagem da PUC-Rio
\end{abstract}

Orientadora: Marcia do Amaral Peixoto Martins

Rio de Janeiro

Abril de 2021 


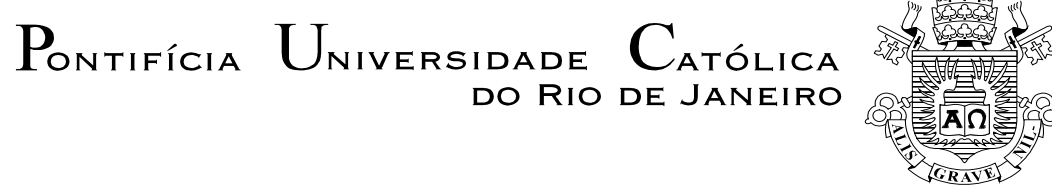

Rosanne Pauzeiro Pousada

Tradução e internacionalização da literatura brasileira: O papel da Fundação Biblioteca Nacional

\begin{abstract}
Dissertação apresentada como requisito parcial para obtenção do título de Mestre pelo Programa de Pós-graduação em Estudos da Linguagem da PUC-Rio. Aprovada pela Comissão Examinadora abaixo assinada
\end{abstract}

Prof. Marcia do Amaral Peixoto Martins

Orientadora

Departamento de Letras - PUC-Rio

Prof. Teresa Dias Carneiro Departamento de Letras - PUC-Rio

Prof. Marta Pragana Dantas

UFPB

Rio de Janeiro, 05 de abril de 2021 
Todos os direitos reservados. É proibida a reprodução total ou parcial do trabalho sem autorização da universidade, da autora e da orientadora.

\section{Rosanne Pauzeiro Pousada}

Graduou-se em Letras pela PUC-Rio em 1984 e especializou-se em Tradução pela Universidade Estácio de Sá em 2016. Iniciou sua vida profissional no magistério, atividade exercida até 1996, quando passou a dedicar-se exclusivamente à tradução. A dedicação exclusiva à tradução durou até 2007, quando passou a acumular a função de servidora da Fundação Biblioteca Nacional (FBN) com a atividade de tradutora. Aposentou-se de sua função na FBN em 2020 e, desde então, vem exercendo unicamente a atividade de tradutora.

Ficha Catalográfica

Pousada, Rosanne Pauzeiro
Tradução e internacionalização da literatura brasileira: O
papel da Fundação Biblioteca Nacional / Rosanne Pauzeiro
Pousada ; orientadora: Marcia do Amaral Peixoto Martins. -
2021.
\[ 268 \text { f. ; } 30 \mathrm{~cm} \]
Dissertação (mestrado)-Pontifícia Universidade
Católica do Rio de Janeiro, Departamento de Letras, 2021.
Inclui bibliografia
1. Letras - Teses. 2. Polissistemas. 3. Patronagem
estatal. 4. Fundação Biblioteca Nacional. 5. Literatura brasileira
em tradução. 6. Internacionalização da literatura brasileira. I.
Martins, Marcia do Amaral Peixoto. II. Pontifícia Universidade
Católica do Rio de Janeiro. Departamento de Letras. III. Título.

CDD: 400 
Ao Marcelo,

Pelo apoio e incentivo. 


\section{Agradecimentos}

À professora Márcia do Amaral Peixoto Martins, minha orientadora.

Ao CNPq e à PUC-Rio, pelos auxílios concedidos, sem os quais este trabalho não poderia ter sido realizado.

Às professoras da banca examinadora.

A todos os professores e funcionários do Departamento de Letras da PUC-Rio pelos ensinamentos e pela ajuda.

A todos os amigos e familiares que de uma forma ou de outra me estimularam ou me ajudaram.

A Fabio Lima, coordenador do Programa de Apoio à Tradução da Fundação

Biblioteca Nacional

O presente trabalho foi realizado com apoio da Coordenação de Aperfeiçoamento de Pessoal de Nível Superior - Brasil (CAPES) - Código de Financiamento 001 


\section{Resumo}

Pousada, Rosanne Pauzeiro. Martins, Marcia do Amaral Peixoto (Orientadora). Tradução e Internacionalização da Literatura Brasileira: O Papel da Fundação Biblioteca Nacional. Rio de Janeiro, 2021. 268 pp. Dissertação de Mestrado - Departamento de Letras, Pontifícia Universidade Católica do Rio de Janeiro.

Esta dissertação tem por objetivo investigar o papel da Fundação Biblioteca Nacional (FBN) na internacionalização da literatura brasileira, diversificando e ampliando a representatividade de nossos autores e obras nos mais diversos centros literários, bem como expandindo os cânones da literatura brasileira no exterior. $\mathrm{O}$ escopo do estudo abrange desde a atuação do órgão no sentido de difundir a literatura brasileira ao redor do mundo até o conjunto de autores favorecidos pelo programa de bolsas de tradução da instituição. O arcabouço teórico contempla a teoria dos polissistemas formulada por Itamar Even-Zohar (1990, 1997 e 2005), os conceitos de reescrita e patronagem de André Lefevere (1992) e a vertente sociológica dos Estudos da Tradução representada por autores como Pascale Casanova (2002 e 2010), Johann Heilbron (2007 e 2010) e Gisèle Sapiro (2007, 2008 e 2014). A análise realizada corrobora a importância da patronagem da literatura brasileira exercida pela Fundação Biblioteca Nacional para reduzir a assimetria das forças existentes no espaço literário internacional, desfavoráveis à literatura produzida no Brasil.

\section{Palavras-chave}

Polissistemas; patronagem estatal; Fundação Biblioteca Nacional; literatura brasileira em tradução; internacionalização da literatura brasileira. 


\section{Abstract}

Pousada, Rosanne Pauzeiro. Martins, Marcia do Amaral Peixoto (Advisor). Translation and internationalization of Brazilian literature: The role of the National Library of Brazil. Rio de Janeiro, 2021. 268 pp. Dissertação de Mestrado - Departamento de Letras, Pontifícia Universidade Católica do Rio de Janeiro.

This thesis aims to investigate the role of the National Library of Brazil (FBN) in the internationalization of the Brazilian literature by diversifying and enlarging the representativeness of our writers and literary works in the various literary centers as well as by expanding the canons of the Brazilian literature abroad. The scope of the study ranges from the FBN's work to disseminate the Brazilian literature around the world to the group of authors favored by the institution's translation grant program. The theoretical framework covers Itamar Even-Zohar's polysystem theory (1990, 1997, 2005), the concepts of rewriting and patronage devised by André Lefevere (1992), and the sociologically-oriented approaches to translation developed by authors such as Pascale Casanova (2002, 2010), Johann Heilbron (2007, 2010) and Gisèle Sapiro (2007, 2008, 2014). The analysis carried out corroborates the importance of the patronage of the Brazilian literature by the National Library of Brazil to reduce the asymmetry of the forces existing in the international literary space, unfavorable to the literature produced in Brazil.

\section{Key words}

Polysystems; state patronage; National Library of Brazil; Brazilian literature in translation; internationalization of Brazilian literature. 


\section{Sumário}

$\begin{array}{ll}\text { Introdução } & 13\end{array}$

1. Fundamentação teórica 21

1.1. A teoria dos polissistemas de Itamar Even-Zohar 22

1.2. O conceito de patronagem de André Lefevere 25

1.3. Reflexões sobre as noções de cânone e o conceito de reescrita 28 de André Lefevere

1.4. As trocas literárias mundiais a partir de uma perspectiva 30 sociológica

1.4.1. Os fluxos tradutórios entre centro e periferia 31

1.4.2. Pascale Casanova e a República Mundial das Letras 34

2. Estratégias da FBN para a promoção da literatura brasileira no 42 exterior

2.1. A participação em feiras literárias internacionais 42

2.2. Programa de Intercâmbio de Autores Brasileiros no Exterior 46

2.3. A publicação de antologias e catálogos especializados 49

2.4. Os prêmios literários $\quad 59$

2.4.1. Prêmio Jabuti 60

2.4.2. Prêmios da Fundação Biblioteca Nacional 64

2.4.3. Prêmio Camões 66

2.5. O programa de bolsas de tradução 67

2.5.1. A história do programa de bolsas de tradução da FBN 68

2.5.2. As regras de concessão das bolsas de tradução 71

2.5.3. Uma análise dos resultados do programa de bolsas 78

3. Os reflexos da patronagem da FBN sobre a circulação dos autores 81 brasileiros no exterior 
3.1. Distribuição das bolsas de tradução por autor e obra 81

3.2. A circulação de Clarice Lispector, Machado de Assis e Jorge 86 Amado no exterior

3.2.1. Machado de Assis na França $\quad 87$

3.2.2. Machado de Assis nos EUA 91

3.2.3. Jorge Amado na França 97

3.2.4. Jorge Amado nos EUA 102

3.2.5. Clarice Lispector na França 107

3.2.6. Clarice Lispector nos EUA 111

3.2.7. Machado de Assis, Jorge Amado, Clarice Lispector e as bolsas 116 de tradução da FBN

3.3. As antologias em língua inglesa e a formação de cânones 117

3.3.1. Granta 121: o apoio a novos autores e a renovação dos 118 cânones

3.3.2. Antologias da revista Litro dedicadas ao Brasil 122

3.3.3. Other Carnivals: New Stories from Brazil 124

3.3.4. Antologias ambientadas no Rio de Janeiro 125

4. A patronagem da FBN: o apoio aos tradutores 130

4.1. Quem traduz as nossas letras: um perfil dos tradutores da 130 literatura brasileira

4.2. O Programa de Residência de Tradutores Estrangeiros no Brasil 138

4.3. Os eventos direcionados aos tradutores 142

4.3.1. As oficinas de tradução 143

4.3.1.1. Oficina de tradução português-alemão e vice-versa 144

4.3.1.2. Entre-Nós-Otros: oficina de tradução português-espanhol e 149 vice-versa

4.3.1.3. Escola de Inverno de Tradução Literária: oficina de tradução 153 português-inglês e vice-versa 
Anexo A - Edital № 1 - 2016 | Programa de Intercâmbio de Autores

Brasileiros no Exterior

Anexo B - Edital № 1 - 2018 | Programa de Apoio à Tradução e à

203 Publicação de Autores Brasileiros no Exterior 2018-2020

Anexo C - Edital N 1 - 2016 | Programa de Residência de

Tradutores Estrangeiros no Brasil

\section{Lista de gráficos}

Gráfico 1: Principais línguas de chegada no espaço literário internacional

Gráfico 2: Principais línguas de partida no espaço literário internacional

Gráfico 3: Número de bolsas de tradução concedidas pelo programa da FBN entre os anos de 1991 e 2018

Gráfico 4: Número de bolsas oferecidas pela FBN aos principais solicitantes

\section{Lista de quadros}

Quadro 1: Feiras literárias internacionais nas quais o Brasil participou como homenageado.

Quadro 2: Países e autores contemplados no Programa de Intercâmbio de Autores Brasileiros no Exterior da FBN, no período de 2012 a 2017.

Quadro 3: Antologias e catálogos publicados pela FBN para divulgar a literatura brasileira no exterior. 
Quadro 4: Membros do conselho editorial da Machado de Assis Magazine.

Quadro 5: Eixos e categorias do Prêmio Jabuti com respectivos anos de lançamento.

Quadro 6: Editoras agraciadas com o Prêmio Jabuti na categoria "Livro Brasileiro Publicado no Exterior", por ano de premiação, obra e autor

Quadro 7: Prêmios literários oferecidos pela FBN e respectivos gêneros contemplados.

Quadro 8: Critérios de avaliação dos prêmios da FBN em 2020.

Quadro 9: Relação de autores contemplados com bolsas da FBN, número de bolsas e países em que foram publicados.

Quadro 10: Obras mais contempladas com bolsas da FBN por autor.

Quadro 11: Obras de Machado de Assis traduzidas para o francês com os respectivos anos de publicação, tradutores, reedições e editoras.

Quadro 12: Obras de Machado de Assis traduzidas para o inglês com os respectivos anos de publicação, tradutores, reedições e editoras.

Quadro 13: Obras de Jorge Amado traduzidas para o francês com respectivos anos de publicação, tradutores, reedições e editoras.

Quadro 14: Obras de Jorge Amado traduzidas para o inglês com respectivos anos de publicação, tradutores, reedições e editoras.

Quadro 15: Obras de Clarice Lispector traduzidas para o francês com os respectivos anos de publicação, tradutores, reedições e editoras.

Quadro 16: Obras de Clarice Lispector traduzidas para o inglês com os respectivos anos de publicação, tradutores, reedições e editoras.

Quadro 17: Autores publicados na Granta com respectivas obras, tradutores e relação de bolsas da FBN concedidas para obras diversas.

Quadro 18: Autores publicados na Litro 114 com respectivos textos e tradutores. e tradutores. 
Quadro 20: Autores publicados na antologia Other Carnivals e respectivos textos.

Quadro 21: Autores publicados na antologia Rio Noir com respectivos textos.

Quadro 22: Autores publicados na antologia The Book of Rio com respectivos textos e tradutores.

Quadro 23: Oficinas de tradução organizadas pela FBN em parceria com outras instituições.

Quadro 24: Tradutores e obras da oficina de tradução portuguêsalemão e vice-versa de Paraty em 2012.

Quadro 25: Tradutores e obras da oficina de tradução portuguêsalemão e vice-versa de Curitiba em 2014.

Quadro 26: Tradutores e obras da oficina de tradução portuguêsespanhol e vice-versa de Porto Alegre em 2012.

Quadro 27: Tradutores e obras da oficina de tradução português156 inglês e vice-versa de Paraty em 2014. 


\section{Introdução}

O presente estudo tem por objetivo investigar o papel desempenhado pela Fundação Biblioteca Nacional (FBN) na internacionalização da literatura brasileira por meio de iniciativas voltadas para a penetração das nossas letras nos mais diversos centros literários mundiais. $\mathrm{O}$ apoio do Estado à literatura produzida no Brasil é essencial para contornar as desvantagens enfrentadas pelos autores ${ }^{1}$ nacionais ao buscar ampliar sua presença no espaço internacional de trocas literárias. Além de analisar a atuação da FBN como incentivadora da presença das letras brasileiras no exterior, o estudo também se propõe a investigar a contribuição do programa de bolsas da instituição para a diversificação da representatividade das nossas letras fora do Brasil e para a formação e a ampliação dos cânones da literatura brasileira para além das nossas fronteiras.

Este estudo foi motivado por artigos de Marcia Martins (2008) e de Lilia Baranski Feres e Valéria Silveira Brisolara $(2015,2018)$, que abordam o incentivo da FBN à internacionalização das letras brasileiras, e por trabalhos de Marta Pragana Dantas (2017, 2019), Lenita Rimoli Esteves (2016) e Maria Lúcia Daflon Gomes (2005), que tratam igualmente de questões relacionadas às trocas literárias na arena internacional. Os estudos empreendidos por essas pesquisadoras abriram diversas possibilidades de exploração do tema do incentivo estatal à circulação da literatura brasileira e suscitaram a necessidade de se elaborar um estudo mais detalhado sobre o desempenho da FBN nesse sentido. Como a iniciativa de promoção das nossas letras empreendida pela instituição já conta trinta anos, o momento parece ser adequado para traçar o percurso das ações levadas a cabo, abordadas até o momento apenas de maneira esparsa e fragmentária, e a uma análise cuidadosa e detalhada das diferentes fases por

\footnotetext{
${ }^{1}$ O Programa de Apoio à Tradução e à Publicação de Autores Brasileiros no Exterior contempla tanto autores/escritores como autoras/escritoras, as quais merecem igualmente destaque nas formas da língua portuguesa. Entretanto, visando não sobrecarregar o texto com a forma "autor(a)/escritor(a)" ou "autores(as)/escritores(as)", o que também implica a necessidade de prever dupla concordância para todos os adjetivos, pronomes e numerais que poderão acompanhar tais vocábulos, optei por usar o genérico masculino, tanto no singular como no plural.
} 
que passou cada uma das atividades desenvolvidas pelo órgão durante esse período, à luz da bibliografia teórica selecionada.

São muitas as literaturas e os autores envolvidos na disputa pelas atenções de editores e outros profissionais do mercado editorial internacional e, para se destacar, a literatura brasileira precisa de uma estratégia muito bem elaborada de divulgação de autores e obras. Foi pensando na inserção dos escritores brasileiros no cenário literário mundial que, em março de 1991, a FBN decidiu criar a Seção de Divulgação Internacional (SDI), dando início a um programa de internacionalização da literatura brasileira com o objetivo de difundir a nossa literatura no exterior de modo que esta alcançasse maior representatividade em um fundo literário mundial, no qual nossa presença é ainda muito discreta, enquanto literaturas de países hegemônicos contam com grande participação. Para atingir essa meta, a FBN baseou-se, a princípio, no seguinte tripé: a divulgação de obras e autores da literatura brasileira em feiras literárias internacionais, a publicação de antologias e catálogos bilíngues especializados em obras e autores nacionais e a concessão de bolsas de tradução das obras da nossa literatura, cujo objetivo é incentivar editoras estrangeiras a publicar no exterior a literatura aqui produzida, criando um público alvo para o autor nacional. A partir da década de 2010, a FBN ampliou sua estratégia de exportação da literatura brasileira, que passou a incluir o Programa de Intercâmbio de Autores Brasileiros no Exterior e o Programa de Residência de Tradutores Estrangeiros no Brasil, além de oficinas de tradução. Todas essas iniciativas fazem parte da atuação da FBN como incentivadora das letras nacionais.

A penetração da literatura brasileira em outros espaços literários enfrenta sérios obstáculos, e o primeiro deles diz respeito à própria língua portuguesa. Por ser uma língua falada apenas em países não hegemônicos, entre eles o Brasil, a língua portuguesa goza de pouco prestígio e visibilidade no cenário internacional. Muitos escritores, por escreverem em língua portuguesa, não conseguem alcançar a notoriedade de autores que produzem suas obras em línguas de maior importância no cenário literário mundial. Mesmo autores que constituem unanimidade em nosso campo literário, como é o caso de Machado de Assis, não conseguiram alcançar grande 
reconhecimento além das fronteiras dos países lusófonos. Como afirma o crítico literário Antonio Candido:

Das línguas do Ocidente, a nossa é a menos conhecida, e se os países onde é falada pouco representam hoje, em 1900 representavam muito menos no jogo político. Por isso ficaram marginais dois romancistas que nela escreveram e que são iguais aos maiores que então escreviam: Eça de Queirós, bem ajustado ao espírito do Naturalismo; Machado de Assis, enigmático e bifronte, olhando para o passado e para o futuro, escondendo um mundo estranho e original sob a neutralidade aparente das suas histórias que todos podiam ler. (Candido, 1995, p. 2)

Da época de Machado de Assis para cá, pouco parece ter mudado. Somos um grupo linguístico importante da perspectiva do número de falantes nativos, no entanto, o número de falantes primários de uma língua não é um fator determinante para caracterizar sua centralidade. $\mathrm{O}$ que realmente define uma língua como central é o número de poliglotas e tradutores que a dominam. Os poliglotas garantem a comunicação entre os falantes das diversas línguas, seja por meio de comunicação direta em uma língua estrangeira, seja pela tradução de uma língua para outra (Casanova, 2010, p. 35).

Para compreender melhor o obstáculo representado pela língua portuguesa como língua de expressão de uma literatura, podemos utilizar os dados do site Index Translationum, um banco de dados dedicado à tradução, cujas informações foram compiladas no período de 1979 a 2009 entre cerca de uma centena de países membros da Unesco e que, no momento, encontra-se em manutenção sem possibilidade de ser consultado. Os dados fornecidos por esse site ilustram bem a situação do Brasil como país não hegemônico no espaço literário internacional ao nos permitir constatar que, embora o português seja a oitava língua de chegada de traduções em todo o mundo, como demonstrado no Gráfico 1, ele sequer aparece entre as dez línguas mais traduzidas em todo o mundo, ocupando uma modesta $18^{\circ}$ posição, atrás até mesmo de línguas com número bem reduzido de falantes, como o dinamarquês e o sueco, como é possível constatar no Gráfico 2. 
Gráfico 1: Principais línguas de chegada no espaço literário internacional.

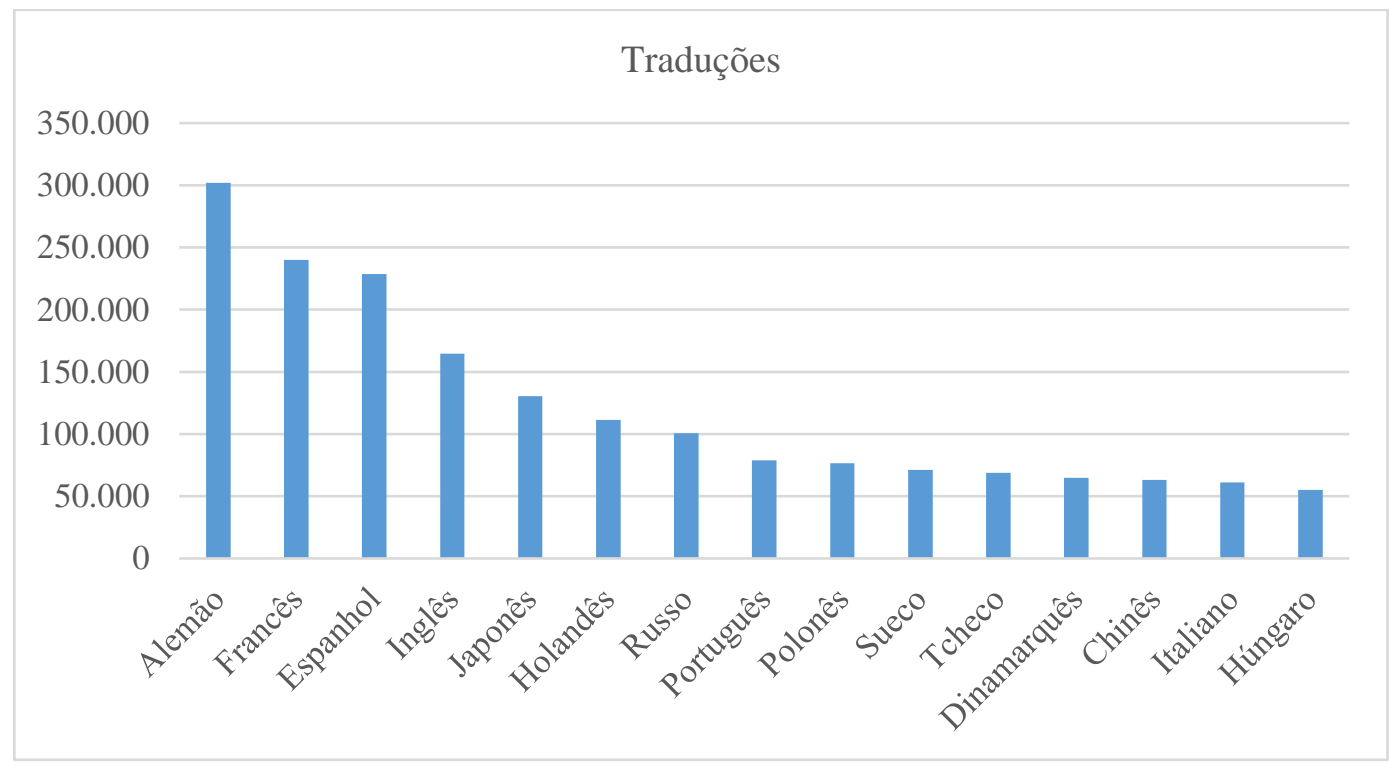

Fonte: Index Translationum

Gráfico 2: Principais línguas de partida no espaço literário internacional

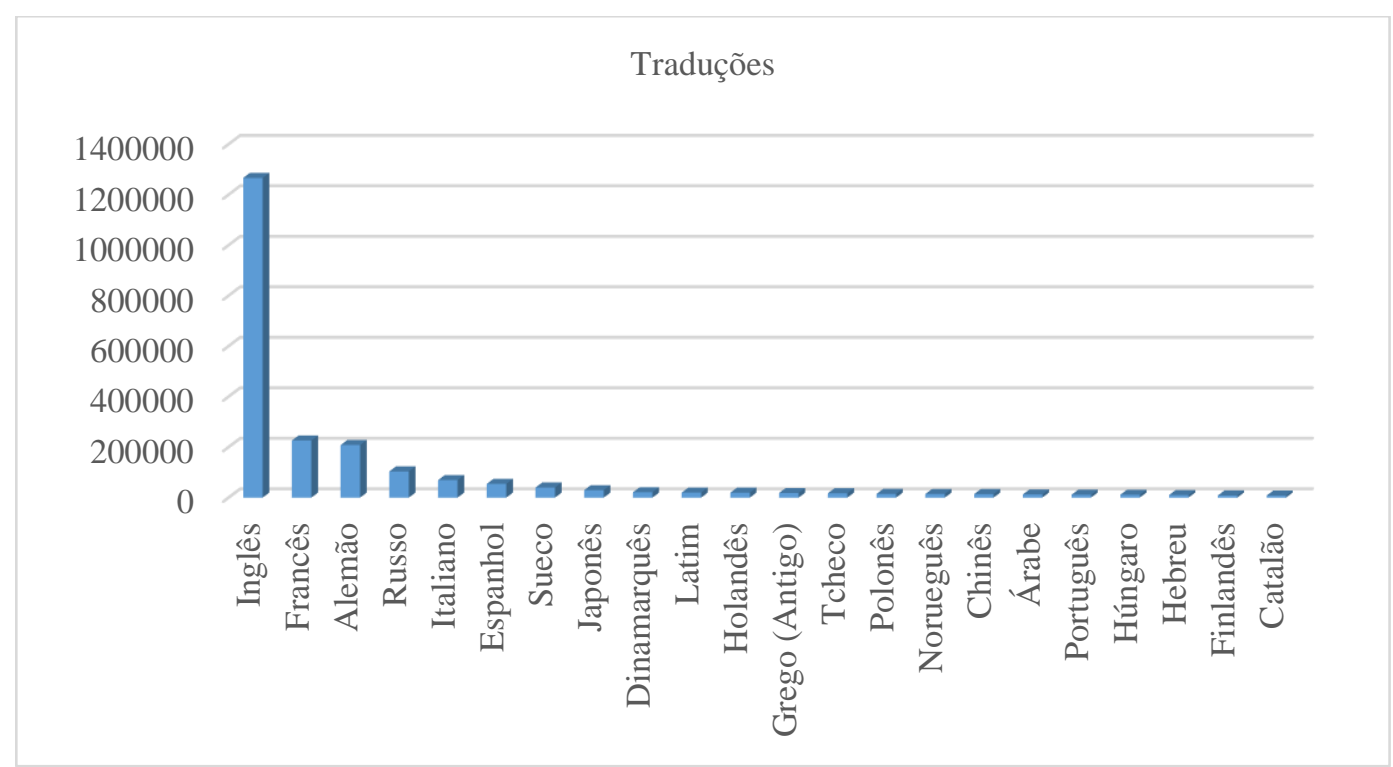

Fonte: Index Translationum

Com base nos dados apresentados acima, concluímos, primeiramente, que os países de língua portuguesa, particularmente o Brasil, traduzem muito, mas são pouco traduzido. Também constatamos que, além de desiguais, os fluxos tradutórios partem de culturas hegemônicas para culturas não hegemônicas, isto é, as línguas que funcionam como principais línguas de partida são, de acordo com a crítica literária 
Pascale Casanova (2002), línguas dominantes, em oposição às línguas dominadas, conceitos que serão discutidos em mais detalhes adiante no capítulo 1. Esse número não se deve apenas a traduções diretas, mas é consequência também de traduções indiretas, já que a comunicação entre línguas dominadas costuma ocorrer por intermédio de uma língua dominante. A consequência da situação descrita nos gráficos 1 e 2 para a penetração da nossa literatura em outras esferas literárias é a dificuldade que os patronos das letras brasileiras encontram para promover e inserir nossas obras e autores em outros sistemas culturais, principalmente nos centros hegemônicos, nos quais uma presença representativa tem como resultado até mesmo a penetração em espaços literários não hegemônicos por meio das traduções indiretas.

Além da desvantagem representada pela língua portuguesa, sofremos também com os clichês relacionados à cultura brasileira. Nossa cultura está associada a um grande número de clichês que, segundo Lenita Esteves (2016, p.11), "proporcionam certa visibilidade, mas, ao mesmo tempo, tornam invisíveis vários de nossos outros traços". Isto é, se por um lado os leitores estrangeiros procuram a nossa literatura quando desejam ler algo associado aos clichês pelos quais somos conhecidos, por outro, somos esquecidos quando esses mesmos leitores estão em busca de leituras sobre temas distantes desses clichês. Nesse sentido, nossa literatura vem contribuindo, juntamente com outras mídias, como o cinema, para criar imagens e representações parciais e estereotipadas da nossa cultura (Martins, 2008, p. 39). É como se, ao estrangeiro, nada mais interessasse sobre o Brasil além de, por um lado, seu exotismo e sensualidade, e, por outro, sua violência e miséria. Como observa o escritor Nelson de Oliveira,

os livros que, depois de saltar todos os obstáculos, conseguem fecundar o mercado europeu e o americano são os que alimentam e realimentam a ideia pré-fabricada que o Primeiro Mundo faz de nós. São os romances entupidos de anedotas exóticas e pitorescas sobre traficantes, favelados, índios, pais-de-santo, bruxos, sambistas e prostitutas. Assim, perpetua-se fora do Brasil o conceito de que aqui não há escritores talentosos, de estilo refinado, em sintonia com outras realidades menos estereotipadas. (2003, p. 29)

Por ser a literatura brasileira ampla e diversa, essa visão restrita de nossa cultura acaba por nos prejudicar. A difusão no exterior de uma imagem mais ampla e abrangente da cultura brasileira contribuiria, sem dúvida, para a eliminação desses 
clichês, libertando a nossa literatura dos estereótipos aos quais ela está relacionada. Diante desse quadro, fugir do lugar-comum e apresentar a nossa cultura e literatura em toda a sua diversidade constituem um grande desafio a ser enfrentado pelos agentes culturais voltados para a promoção das nossas letras fora do Brasil.

Lawrence Venuti (2013, p. 160) reforça a ideia de que a literatura traduzida projeta imagens metonímicas de uma cultura, ao chamar a atenção para a descontextualização radical de uma obra traduzida, já que a tradução promove a alienação entre um texto fonte e tudo o que o torna significativo na cultura em que se originou. Essa situação é agravada ainda mais em virtude da disponibilidade limitada de obras em tradução. Tradições literárias inteiras, até mesmo cânones literários inteiros, nunca são traduzidos para uma língua específica e, como resultado, um leitor estrangeiro raramente dispõe de uma seleção diversificada e substancial de obras coevas em tradução em um dado momento, adquirindo uma visão fragmentária de uma literatura. A fim de mitigar as consequências adversas do número reduzido de obras de uma literatura em tradução, é preciso fomentar a diversidade e o volume do que é traduzido para outros sistemas literários.

Essas são as principais dificuldades enfrentadas pela nossa literatura ao tentar penetrar centros literários internacionais; portanto, é esse o cenário inicial com o qual se deparam os agentes culturais, sejam eles autores, tradutores, agentes literários, editores ou instituições governamentais, ao traçar como objetivo a promoção da literatura brasileira no exterior. Apesar do quadro desalentador, alguns agentes envolvidos na divulgação da nossa literatura no exterior têm conseguido vitórias expressivas nos últimos anos. Como exemplo, menciono o trabalho desempenhado por Benjamin Moser, biógrafo e tradutor de Clarice Lispector que conseguiu divulgar a obra da autora de forma a torná-la conhecida e admirada nos principais centros editoriais do mundo. No entanto, para divulgar a literatura brasileira fora de nossas fronteiras sem que esse esforço fique restrito a alguns casos de sucesso, é bem-vinda a intervenção do governo no sentido de promover obras e autores de forma ampla e irrestrita. Este estudo trata exatamente das diversas estratégias empregadas pela FBN, como agente estatal de fomento da cultura e da literatura brasileiras no cenário mundial, para superar essas e outras adversidades, além de discorrer sobre a forma como o apoio 
da instituição influencia outros envolvidos na promoção da nossa literatura, como autores, tradutores ou editoras.

As teorias, as abordagens e os conceitos que informam esta pesquisa são apresentados no capítulo 1, tendo como eixos principais: (i) a teoria dos polissistemas de Itamar Even-Zohar (1990), muito importante para o presente estudo, que busca posicionar o sistema literário brasileiro em relação aos demais sistemas literários ao redor do mundo, abordando, particularmente, os percalços enfrentados pela literatura brasileira para penetrar diferentes sistemas de literatura traduzida; (ii) as noções de reescrita e patronagem, desenvolvidas por André Lefevere, aplicadas particularmente ao papel da FBN de apoio à difusão da nossa produção literária; (iii) uma vertente da sociologia da tradução, representada pelas concepções dos sociólogos Johann Heilbron e Gisèle Sapiro e da crítica literária Pascale Casanova, que retratam a relação entre literaturas hegemônicas e não hegemônicas no espaço literário mundial como uma arena em que grupos linguísticos de maior ou menor prestígio travam relacionamentos que envolvem competição e rivalidade; e (iv) a concepção de Bourdieu das formas de capital, uma vez que estas muito influenciam, ou até mesmo regem, as atividades dos agentes na esfera editorial e das trocas literárias. O capítulo inclui ainda uma discussão sobre as possíveis definições de cânone, conceito abordado em diversos momentos do trabalho.

O capítulo 2 dá início à análise das estratégias de internacionalização da literatura brasileira colocadas em prática pela $\mathrm{FBN}$, dentre as quais se destacam a participação da instituição em feiras internacionais, a fim de divulgar obras e autores nacionais, o incentivo à participação de autores brasileiros em eventos e feiras literárias fora do território brasileiro, a edição e distribuição no exterior de antologias, catálogos e outras publicações bilíngues de apresentação da literatura produzida no Brasil, a entrega de prêmios literários concedidos pela instituição, mais uma forma de incentivar autores nacionais e, por último, a cessão de bolsas de tradução de obras brasileiras a editoras estrangeiras

O capítulo 3 aborda em detalhes o programa de bolsas de tradução da FBN, incluído no Programa de Apoio à Tradução e à Publicação de Autores Brasileiros no Exterior, e analisa os efeitos suscitados, até o momento, pelo projeto sobre a circulação 
dos nossos autores no exterior. Esse programa, tal como iniciativas semelhantes colocadas em prática por outros países, demonstra a importância do apoio do setor público à exportação da literatura brasileira, mais abrangente do que as iniciativas privadas, e, portanto, capaz de empreender esforços maciços de divulgação de obras e autores brasileiros, em contraponto aos esforços da iniciativa privada, que costumam surtir efeitos pontuais, como a promoção de um único autor ou de uma obra específica por vez. Nesse sentido, as iniciativas do governo têm o poder de ampliar e diversificar a presença de obras e autores brasileiros no exterior. A análise de resultados é empreendida a partir dos dados levantados sobre os escritores brasileiros publicados com o apoio do programa, com vistas a investigar a contribuição dessa iniciativa para a diversificação da representatividade das nossas letras fora das fronteiras nacionais e para a formação e a ampliação de cânones da literatura brasileira em centros literários internacionais.

O capítulo 4 traça um perfil do tradutor da literatura brasileira e aborda as estratégias da FBN voltadas para esses profissionais, dentre elas o Programa de Residência de Tradutores Estrangeiros no Brasil - que atende aos tradutores estrangeiros interessados em realizar uma imersão na nossa cultura a fím de empreender pesquisas relacionadas à tradução de uma obra da literatura brasileira ainda em processo de elaboração - e as oficinas de tradução bilíngues, nas quais os participantes, tradutores nativos de duas línguas distintas, dentre elas o português, apresentam e discutem seus respectivos projetos de tradução, trocando experiências e solucionando dúvidas.

Nas considerações finais, analiso as consequências da atuação da FBN no sentido de ampliar e diversificar a presença de obras e escritores brasileiros fora do território nacional, assim como de reequilibrar as forças existentes no espaço literário internacional, no qual as literaturas de culturas hegemônicas encontram-se em franca vantagem, desfrutando de grande penetração no nosso campo literário, enquanto a literatura brasileira esbarra em sérias restrições de internacionalização por ser o Brasil uma cultura periférica. 


\section{1.}

\section{Fundamentação teórica}

No passado, as reflexões e teorias sobre a tradução tinham um caráter eminentemente prescritivo, visando a ditar regras para o bem traduzir, e os estudos realizados voltavam-se sobretudo para os aspectos linguísticos e para as relações entre o texto de partida e o texto de chegada. No entanto, diante das limitações das abordagens prescritivas e textuais, a partir de meados da década de 1970 desenvolveuse e consolidou-se uma vertente descritiva e sistêmica dos Estudos da Tradução, cujo foco de atenção se voltou para uma série de questões extratextuais relacionadas às funções de uma tradução, ao contexto no qual ela ocorre e às coerções, tanto políticas quanto econômicas, que pesam sobre ela. Essa nova abordagem do fenômeno tradutório era representada por um grupo de teóricos que tinham em comum

[...] uma visão de literatura como um sistema complexo e dinâmico; uma convicção de que deveria haver uma interação contínua entre modelos teóricos e estudos de casos práticos; uma abordagem da tradução literária descritiva, orientada para o texto de chegada, funcional e sistêmica; e um interesse nas normas e coerções que regem a produção e recepção de traduções, na relação entre tradução e outros tipos de processamento de texto, e na posição e no papel das traduções tanto dentro de uma literatura específica quanto na interação entre literaturas. (Hermans, 1985, p. 10-11) ${ }^{2}$

Essa vertente descritiva dos Estudos da Tradução foi desenvolvida por estudiosos vinculados a universidades em Leuven (Bélgica), Amsterdã (Holanda) e Tel-Aviv (Israel), e tem como três de seus principais expoentes Itamar Even-Zohar, Guideon Toury e André Lefevere, teóricos advindos da literatura comparada cujos conceitos serão abordados em detalhes neste capítulo.

Embora as preocupações com o papel social da tradução já marquem a teoria desenvolvida por Even-Zohar, Toury e Lefevere, alguns aspectos do fenômeno

\footnotetext{
${ }^{2}$ a view of literature as a complex and dynamic system; a conviction that there should be a continual interplay between theoretical models and practical case studies; an approach to literary translation which is descriptive, target-oriented, functional and systemic; and an interest in the norms and constraints that govern the production and reception of translations, in the relation between translation and other types of text processing, and in the place and role of translations both within a given literature and in the interaction between literatures. (Todas as traduções de citações extraídas de obras em língua inglesa são de minha autoria.)
} 
tradutório ainda não recebiam a devida atenção, entre eles o papel dos agentes - por exemplo, autores, tradutores, editores, críticos e agentes literários - e das instituições - tais como escolas de tradução, periódicos literários e acadêmicos, editoras e associações profissionais - envolvidos nessa atividade. Esse aspecto da tradução acaba por despertar o interesse de teóricos que dão origem à vertente sociológica dos Estudos da Tradução. Neste estudo lanço mão, particularmente, da linha de pesquisa no âmbito da Sociologia da Tradução que objetiva explicar o papel da tradução nas trocas culturais transnacionais e cujos principais representantes são os sociólogos Gisélè Sapiro e Johan Heilbron bem como a crítica literária Pascale Casanova.

\section{1.}

\section{A teoria dos polissistemas de Itamar Even-Zohar}

Na década de 1970, Itamar Even-Zohar, um sociólogo, linguista e professor de literatura da Universidade de Tel-Aviv, partiu do princípio, introduzido na teoria literária moderna pelos formalistas russos, de que um sistema semiótico - tal como uma cultura, uma linguagem, uma literatura ou uma sociedade - pode ser considerado uma estrutura dinâmica, aberta e heterogênea. Consequentemente, ele raramente constitui um monossistema, tratando-se, na maioria dos casos, de um polissistema, isto é, "um sistema de vários sistemas que se entrecruzam e, em parte, se sobrepõem, que usam opções concorrentemente diferentes, mas que funcionam como um todo estruturado, cujos membros são interdependentes"33 (Even-Zohar, 1997, p. 11). Para o teórico, uma cultura é um polissistema composto por diversos sistemas - como o religioso, o econômico, o político, o literário e outros - que, por sua vez, são formados por subssistemas. Essa ideia constitui a base da teoria dos polissistemas, que EvenZohar desenvolveu e aperfeiçoou até a década de $1990 .^{4}$

Um dos vários sistemas que compõem uma cultura, como foi mencionado, é o sistema literário, principal objeto de estudo de Even-Zohar, formado por diversos sistemas em constante comunicação. Por exemplo, o sistema de literatura para crianças

\footnotetext{
${ }^{3}$ a system of various systems which intersect with each other and partly overlap, using concurrently different options, yet functioning as one structured whole, whose members are interdependent.

${ }^{4}$ Ao longo deste estudo, os termos "sistema" e "polissistema" serão usados intercambiavelmente.
} 
deve ser considerado em sua interação com o sistema de literatura para adultos, assim como o sistema de literatura traduzida, de existência postulada pelo teórico, deve ser estudado em sua relação com o sistema de literatura nativo, e o sistema de literatura de massa - incluindo suspenses, romances policiais e outros gêneros pouco prestigiados deve ser compreendido como complementar ao sistema de alta literatura.

O centro do polissistema literário é ocupado pelos cânones, instituídos pelos grupos que detêm o poder em uma cultura e que tendem a determinar quais são os modelos a serem seguidos pelos integrantes do sistema, os quais, ao se aproximarem das orientações dos grupos dominantes, adquirem prestígio e status. Ao redor do sistema de literatura canônica, encontram-se os demais sistemas que, longe de uma acomodação, vivem uma constante tensão na disputa para ocupar a posição central. Cabe destacar que os cânones não ocupam o centro devido a qualidades supostamente intrínsecas dos textos que deles fazem parte, mas em virtude da influência daqueles que detêm o poder e que impõem seus modelos literários aos demais integrantes do sistema.

A visão da literatura como um polissistema teve como consequência uma valorização dos sistemas periféricos, que passaram a constituir importante tema de estudos, uma vez que ajudam a compreender melhor o sistema que ocupa o centro do polissistema, com seus valores, interesses e estratégias. Além disso, o estudo da literatura, de acordo com a visão sistêmica, exige que o objeto de estudo não se restrinja apenas ao texto em si, uma vez que as interações com os outros integrantes do polissistema literário são igualmente importantes para a compreensão de uma obra literária.

A visão da literatura como um conjunto de sistemas, introduzida por EvenZohar, foi extremamente benéfica para a literatura traduzida, que até então era vista como um conjunto esparso de obras consideradas isoladamente que não mantinham relação nenhuma umas com as outras. A partir da teoria dos polissistemas, a literatura traduzida veio a ser estudada como um sistema que interage com outros sistemas literários e cujos próprios elementos interagem entre si, e passou-se a tentar compreender os princípios que regem a seleção de certos textos para tradução em detrimento de outros. 
Even-Zohar aprofundou bastante o estudo do sistema de literatura traduzida, descrito por ele como um sistema que pode ocupar posição periférica ou central, mas que, de forma geral, assume posição marginal e exerce pouco ou nenhum poder sobre os cânones literários da cultura de recepção, funcionando apenas como um instrumento de conservação dos próprios cânones. Em posição periférica, o sistema de literatura traduzida leva à produção de traduções adaptadas aos modelos existentes na cultura de chegada e distantes dos modelos da cultura de origem, o que impede a introdução de inovações na forma e nos temas abordados pela literatura da cultura de recepção. Nessa configuração, a tradução, que pode ser usada como veículo para a introdução de novas ideias, itens e características, torna-se um meio de preservação do gosto tradicional.

No entanto, quando a tradução ocupa uma posição mais central no polissistema literário, devido a circunstâncias que serão apresentadas a seguir, a literatura traduzida pode exercer um papel inovador, importando repertórios e modelos de outras culturas, não se prendendo aos cânones locais e contribuindo para a transformação e a configuração da cultura de recepção. Entre essas inovações é possível citar novas linguagens poéticas, bem como técnicas e padrões composicionais. Um exemplo representativo de inovação formal pode ser a introdução do soneto italiano na língua portuguesa. Nesse cenário, deixa de haver uma distinção clara entre as obras originais e as obras traduzidas, e os escritores de maior prestígio assumem a tarefa de produzir traduções. A própria seleção dos textos a serem traduzidos reflete a situação vivida pelo sistema-alvo: são escolhidos textos para tradução que possam contribuir para a inovação do sistema.

Even-Zohar aponta três situações em que o sistema literário de recepção está aberto a sofrer influências da literatura traduzida: (a) quando uma literatura jovem ainda não se consolidou; (b) quando uma literatura é periférica em relação a um grupo maior de literaturas correlatas; e (c) quando ocorrem crises ou vácuos em determinada literatura. No primeiro caso, a literatura traduzida supre uma carência de uma literatura mais jovem. Como uma literatura jovem não consegue produzir, de imediato, textos de todos os tipos para preencher suas lacunas literárias, ela lança mão da experiência de outras literaturas por meio da tradução. Esse é o caso das literaturas de países jovens cuja cultura ainda não foi consolidada, como ocorreu com Israel após a sua fundação. 
O mesmo princípio se aplica a literaturas já estabelecidas, mas que ainda contam com repertórios limitados. Essas também se valem de traduções para suprir suas necessidades. É importante observar que essas literaturas têm capacidade limitada de empreender inovações por conta própria sem depender de literaturas maiores e mais centrais, o que pode resultar em uma relação de dependência não apenas de sua literatura periférica, mas também de seu próprio centro. Enquanto as literaturas fortes podem adotar inovações de literaturas periféricas apenas como mais uma opção, aquelas ditas fracas dependem exclusivamente de importações para se renovar. As dinâmicas existentes em um sistema literário também criam pontos de virada, ou seja, momentos em que os modelos estabelecidos já não bastam a uma geração jovem insatisfeita com os itens em inventário na literatura local e em busca de inovação. Essa situação pode ser observada no Romantismo alemão, quando a tradução foi proposta como meio de renovação da língua e da literatura alemãs. Em momentos assim, a literatura traduzida pode assumir um papel central mesmo em literaturas fortes. Nesse caso, como o objetivo maior da tradução não é obter a aceitação do grupo que detém o poder no sistema, mas justamente transformar esse sistema ampliando seu repertório, o texto tende a aderir aos modelos da cultura de origem.

Neste estudo, adoto a abordagem sistêmica para investigar a interação entre o polissistema literário brasileiro e os sistemas de literatura traduzida de outras culturas, analisando as diversas iniciativas da FBN de exportação de itens da literatura brasileira, que incluem desde obras canônicas até textos de sistemas periféricos, contemplando diversos gêneros, como os clássicos do século XIX, os modernistas do século XX e os autores contemporâneos, entre outros.

\section{2.}

\section{O conceito de patronagem de André Lefevere}

Assim como Itamar Even-Zohar, o teórico da literatura e estudioso da tradução André Lefevere pensou a cultura como um grande sistema aberto e interativo, composto por diversos subssistemas, dentre os quais o literário. No entanto, para que o sistema literário não se afaste dos demais, ele é regulado por dois mecanismos de 
controle: um interno e outro externo. O mecanismo interno é representado pelos profissionais do meio literário, como escritores, professores de literatura, críticos, revisores e tradutores; enquanto o mecanismo externo, denominado patronagem, representa os "poderes (pessoas, instituições) capazes de coibir ou incentivar a leitura, a escrita e a reescrita da literatura"5 (Lefevere, 1992, p. 14). A patronagem impõe coerções, principalmente de cunho ideológico, sobre a literatura de uma cultura, enquanto transfere aos profissionais poderes para regular a poética.

A patronagem é exercida por indivíduos, como os mecenas, ou por grupos sociais, como entidades religiosas, partidos políticos e classes sociais. O poder dos patronos costuma ser exercido por meio de instituições, como editoras, órgãos governamentais, departamentos de censura, periódicos de crítica literária e, a mais importante delas, o sistema educacional. Essas instituições têm por objetivo regular, se não a literatura, ao menos sua distribuição. Os patronos mantêm uma relação muito próxima com os profissionais que representam os princípios dominantes em um dado momento no desenvolvimento de uma sociedade e contam com eles para manter a literatura alinhada à ideologia que representam.

Lefevere divide a patronagem em três componentes: ideológico, econômico e de status. O componente ideológico atua sobre a escolha da forma adotada e sobre o desenvolvimento do assunto abordado. Lefevere não usa o termo "ideologia" no sentido político, mas em um sentido amplo, que inclui convenções e crenças. $\mathrm{O}$ componente econômico é representado pela iniciativa do patrono de garantir que escritores e outros agentes do meio literário consigam se sustentar por meio de sua atividade profissional. Em certos casos, o profissional recebe uma pensão ou é indicado para um cargo remunerado, já em outros ele se torna professor ou crítico. O terceiro elemento da patronagem é o status: viver sob a proteção de um patrono implica integrar um círculo e adotar o estilo de vida comum a seus membros, adquirindo em troca o status do qual goza o próprio patrono (Lefevere, 1992, p. 15-16).

Lefevere classifica ainda a patronagem em diferenciada e indiferenciada (Lefevere, 1992, p. 16). A patronagem é indiferenciada quando seus três componentes

\footnotetext{
${ }^{5}$ Powers (persons, institutions) that can further or hinder the reading, writing, and rewriting of literature
} (p. 14) 
- ideológico, econômico e de status - ficam a cargo de um único patrono, o que costumava ocorrer no passado, por exemplo, quando um rei absolutista recebia um escritor em sua corte, garantindo a ele meios de sobrevivência e status em troca de adesão à sua ideologia. No caso da patronagem diferenciada, por outro lado, o sucesso econômico é relativamente independente de fatores ideológicos e não propicia necessariamente status junto à elite literária, como ocorre com muitos autores de bestsellers, que conquistam grande sucesso de vendas, embora nunca contem com o reconhecimento de seu valor literário por parte da crítica especializada.

O governo brasileiro age como patrono das letras nacionais por meio da FBN, uma das instituições que o representa, assegurando para si a prerrogativa de incentivar e financiar a exportação da literatura brasileira, com o objetivo de exercer sobre as demais nações um poder brando, o chamado soft power, o poder da influência sutil, do convencimento. O Brasil não conta com grande poderio militar ou econômico, que caracteriza o hard power, mas seus produtos culturais gozam de certa visibilidade no exterior, conferindo ao país influência sobre outras culturas. Além do componente ideológico, a FBN é também corresponsável pelo componente econômico da patronagem que exerce sobre as letras nacionais, ao subvencionar a tradução de obras e autores brasileiros no exterior. A patronagem da instituição favorece, diretamente, as editoras estrangeiras, cuja tradução de obras produzidas no Brasil é financiada pela instituição, e, indiretamente, tanto os tradutores da língua portuguesa, destinatários imediatos da subvenção do governo brasileiro, quanto os autores da literatura brasileira, beneficiários finais da iniciativa. Por último, a publicação em centros literários estrangeiros garante ao autor status no sistema literário de origem, sendo essa mais uma consequência da patronagem exercida pelo governo do Brasil.

Como é comum na atualidade, a patronagem da FBN é diferenciada, isto é, embora a instituição detenha para si a prerrogativa de orientar a ideologia, ela divide com outros agentes a responsabilidade pelos componentes econômico e de status. $\mathrm{O}$ componente econômico é dividido entre a FBN e as editoras estrangeiras, ambas parcialmente responsáveis pela publicação de uma obra da literatura brasileira no exterior, e o componente de status é conferido por diferentes agentes que atuam no campo literário e editorial e pelos próprios leitores aos autores publicados no exterior. 


\section{3.}

\section{Reflexões sobre as noções de cânone e o conceito de reescrita de André Lefevere}

O conceito de cânone está no centro de um debate travado há bastante tempo sobre o que leva um trabalho de criação literária a fazer parte de um seleto grupo de obras consideradas exemplares, alçadas à categoria de patrimônio da humanidade, e que, portanto, devem ser preservadas para as futuras gerações. De um lado, está uma corrente de teóricos da literatura para os quais a canonização de uma obra decorre de um suposto valor intrínseco a ela atribuído, enquanto de outro estão estudiosos para quem esse valor não existe, estando em jogo, portanto, outros fatores, perspectiva adotada neste estudo. $\mathrm{O}$ primeiro grupo acredita em valores puramente estéticos que, nas palavras de Harold Bloom (2013, p. 14), um dos representantes dessa corrente, levam o leitor a sentir um certo "estranhamento", uma originalidade, ao ler uma obra canônica, característica que bastaria para que uma obra nunca se afastasse do cânone. O segundo grupo, no entanto, acredita que a resposta de um leitor a uma obra é condicionada pelas normas e pelos valores vigentes em sua comunidade em dado momento, e não por valores estéticos atemporais. Os cânones traduzem os valores dos grupos sociais que os produzem, portanto, a noção de valor literário inquestionável teria se desintegrado (Bennett; Royle, 2004, p. 47). Por esse motivo, costuma-se preferir a expressão "obra canonizada" a "obra canônica", como faz Even-Zohar (2005), já que a primeira faz transparecer a ação de terceiros para que um dado produto de criação literária faça parte de uma relação de obras consagradas. Se por um lado, o primeiro grupo acha que uma obra canônica tem algo de novo, de transgressor, que se mantém ao longo do tempo, por outro, o segundo grupo acredita que uma obra não pode permanecer inovadora durante séculos de existência, a menos que seja submetida a constantes releituras que acrescentem a ela um novo frescor, alguma originalidade. A essas releituras, André Lefevere (1992, p. 1) dá o nome de reescritas e considera que somente por meio delas uma obra é capaz de manter sua canonicidade. As reescritas são metatextos de obras literárias, como críticas, traduções e adaptações, que garantem a sobrevivência de um texto literário, isto é, sucessivas gerações reescrevem os textos 
canônicos reafirmando sua atualidade. Os reescritores são profissionais, como tradutores, críticos, editores de antologias literárias e outros, que, por meio do trabalho que realizam, se tornam responsáveis pela sobrevivência das obras literárias entre os leitores leigos e, nesse aspecto, desempenham papel tão ou mais importante do que os próprios escritores. São os reescritores que garantem leitores de sucessivas gerações a uma obra literária e não um suposto valor intrínseco, que, na opinião de uma corrente de estudiosos, determinaria a sobrevida de um texto literário.

Alinhando-me a Lefevere e outros teóricos, considero que a sobrevivência de uma obra é, portanto, resultado do trabalho de instituições ou agentes dos meios acadêmicos, literários e editoriais em condições de determinar quais obras literárias devem ser lidas, relidas e estudadas. Para Lefevere (1992, p. 20), as instituições que regulam os cânones dividem-se entre aquelas que desempenham um papel importante na admissão de novas obras a esse seleto grupo, como a academia ou as editoras de alta literatura, e aquelas que o mantêm vivo por meio da indicação e seleção de textos para leitura, como as universidades, os jornais e suplementos literários, as antologias e os currículos escolares e universitários, as resenhas e críticas literárias, as comendas e prêmios, as adaptações para outras mídias, como o cinema e a televisão, entre outros.

Veremos no capítulo 3 que a FBN, por meio do apoio dado à publicação de uma série de antologias bilíngues de autores brasileiros, desempenha um papel fundamental na admissão de obras literárias em um cânone "oficial" (uma vez que determinado por uma instituição pública) da literatura brasileira nos mais diversos sistemas de literatura traduzida ao redor do mundo. Veremos também que a instituição conta com a colaboração de diretores de bibliotecas públicas, críticos e professores para a seleção dos autores que figurarão em suas antologias, profissionais que, de acordo com Lefevere, são responsáveis pela manutenção dos cânones literários por meio da indicação para leitura de obras e autores específicos. Em virtude de sua contribuição para a formação de cânones nos sistemas de literatura traduzida de outras culturas alcançados por seu programa de bolsas, é importante que a FBN esteja atenta às consequências que podem ser geradas, quando da publicação de suas antologias, pelas escolhas de certos autores e textos em detrimento de outros, uma vez que estas geram 
visões parciais de nossa literatura. Portanto, para não incorrer no risco de apresentar uma visão incompleta da literatura brasileira no exterior, Marcia A. P. Martins sugere

não só intensificar a tradução e a circulação das nossas obras e autores, como também difundir uma produção literária mais diversificada, favorecendo estilos, temáticas e escolas/vertentes variadas - o que implica, em última análise, mudar ou ampliar o(s) cânone(s) de literatura brasileira traduzida que vigora(m) nos sistemas receptores. (2008, p. 40)

Assim, é importante que a FBN contemple as diferentes correntes de nossa literatura em suas antologias de modo a colaborar com a divulgação no exterior, não de um único cânone da literatura brasileira, mas de vários, todos eles bastante diversificados.

Ainda sobre o tema dos cânones e de sua difusão em sistemas de literatura traduzida no exterior, o capítulo 3 traz um estudo sobre a relação entre os autores brasileiros divulgados nas antologias publicadas pela FBN e as solicitações de bolsas de tradução da instituição concedidas a editoras estrangeiras, visando detectar a influência das antologias da instituição sobre a formação ou a ampliação dos cânones da literatura nacional.

\section{4.}

\section{As trocas literárias mundiais a partir de uma perspectiva sociológica}

A Sociologia da Tradução, da qual lanço mão para explicar os fenômenos relacionados à interação entre línguas e literaturas dos diferentes espaços literários nacionais, contesta a explicação para o fenômeno tradutório oferecida tanto pela abordagem interpretativa textual quanto pela análise econômica de trocas transnacionais. Por um lado, a abordagem interpretativa não leva em conta as condições sociais do ato interpretativo, o que equivale a ignorar a pluralidade de agentes envolvidos na atividade tradutória, bem como as funções que a tradução pode desempenhar. Por outro lado, a abordagem econômica inclui as obras traduzidas em uma categoria mais geral de bens, identificando-as como mercadorias produzidas, distribuídas e consumidas de acordo com a lógica dos mercados nacionais e 
internacionais. No entanto, considerar obras traduzidas como mercadorias como outras quaisquer oculta a especificidade tanto da produção quanto da comercialização de bens culturais. O mercado de bens simbólicos constitui um tipo particular de economia que funciona de acordo com seus próprios critérios de valor, merecendo, portanto, análise específica (Heilbron; Sapiro, 2007, p.97).

A partir dessa perspectiva, apresento, a seguir, como aporte teórico para o estudo aqui desenvolvido, os conceitos dos sociólogos Gisélè Sapiro e Johan Heilbron e da crítica literária Pascale Casanova, que tecem reflexões importantes sobre o mercado de bens simbólicos, particularmente sobre as trocas literárias transnacionais, que são analisadas nas relações entre grupos linguísticos, e não entre estados-nação.

\subsection{1.}

\section{Os fluxos tradutórios entre centro e periferia}

Os sociólogos Gisélè Sapiro e Johan Heilbron (2007, p. 96) abordam o fluxo internacional de traduções com base no modelo centro-periferia, que define a centralidade de uma língua no sistema internacional de traduções de acordo com a proporção de obras traduzidas a partir dela. Os autores usam os dados do site Index Translationum, um banco de dados da Unesco dedicado à tradução, para demonstrar que a língua inglesa é o ponto de partida de um número bastante alto de traduções, o que garante a ela o status de língua hipercentral. De acordo com a pesquisa empreendida por eles, na década de 1980, 45\% dos livros traduzidos tinham como ponto de partida a língua inglesa. O alemão, o francês e o russo eram as línguas de origem de $10 \%$ a $12 \%$ das traduções, o que lhes garantia uma posição central. Em seguida, encontramos algumas outras línguas europeias que constituem a língua de partida de $1 \%$ a $3 \%$ do mercado internacional de traduções. São as chamadas línguas semiperiféricas, como o italiano e o espanhol. Todas as outras línguas, inclusive o português, têm uma participação de menos de $1 \%$ no mercado internacional e, portanto, podem ser consideradas periféricas, apesar do fato de algumas representarem grupos linguísticos importantes da perspectiva do número de falantes nativos, como o chinês e o próprio português. Esses dados nos levam à conclusão de que 3/4 do número total de 
obras traduzidas no mundo inteiro à época - anos 1980 - tinha como ponto de partida apenas quatro línguas. Na década de 1990, essa configuração se alterou em relação à língua russa, que perdeu prestígio com a queda da União Soviética e passou a ter uma participação de apenas 2,5\% no mercado internacional, e em relação à língua inglesa, que se tornou ainda mais central e passou a funcionar como a língua de partida de $59 \%$ das traduções. Esse número não se deve apenas a traduções diretas, mas, de acordo com os autores, é consequência também de traduções indiretas, já que a comunicação entre línguas periféricas costuma ocorrer por intermédio do centro, ou seja, quanto mais central for uma língua, maior será a probabilidade de que funcione como língua intermediária entre duas outras. Sendo assim, a tradução de uma obra escrita em uma língua periférica, como, por exemplo, o português, para uma língua central, como o inglês, o francês ou o alemão, tem o poder de provocar grandes expectativas nos agentes culturais, uma vez que ela pode desencadear uma sucessão de traduções para outras línguas.

Ainda de acordo com os autores (Sapiro; Heibron, 2007, p. 96), um dos traços mais característicos do funcionamento do espaço literário internacional diz respeito à relação entre o grau de centralidade da tradução e sua importância para a literatura de um país. Enquanto os países hegemônicos exportam bastante seus produtos culturais e importam poucas traduções para a própria língua, os países periféricos exportam pouco e importam muitos títulos estrangeiros, principalmente por meio de traduções. Essa constatação é reforçada pelos números apresentados pelos autores relativos à década de 1990, quando a proporção de obras traduzidas representava, na Inglaterra e nos Estados Unidos, menos de $4 \%$ da produção nacional (embora, em número absolutos, os Estados Unidos contem com quantidade significativa de obras traduzidas, já que o mercado editorial americano é bastante expressivo). Na Alemanha e na França, essa proporção aumentou para algo em torno de 14\% a 18\%. Na Itália e na Espanha, o percentual atingiu 24\%. O Brasil não foi contemplado na pesquisa dos autores, mas dados colhidos pela Fundação Instituto de Pesquisas Econômicas (Fipe) em 2018 apontavam para uma proporção que chegava a quase $40 \%$ de obras traduzidas em relação ao total de títulos lançados no mercado editorial brasileiro. Esses dados parecem sinalizar uma relação inversa entre o grau de centralidade de uma língua no 
sistema internacional de traduções e a parcela de traduções na produção nacional livreira: quanto mais central for a produção cultural de um país, menor será a proporção de materiais traduzidos para essa língua, enquanto, por outro lado, maior será seu papel como referência para outros países.

Ainda de acordo com Sapiro (2014, p. 86-87), pesam sobre a produção e a circulação de obras literárias no espaço internacional dois tipos de coerções: políticas (ou ideológicas) e econômicas. A tradução pode servir a objetivos políticos e ideológicos e ser um meio de disseminação de uma doutrina ou visão de mundo. Como exemplo, a autora cita a contribuição de organizações e partidos políticos para a divulgação das obras de Marx e Engels em tradução. Entretanto, o apoio de governos à tradução literária nem sempre tem caráter ideológico. Os programas de tradução implementados por estados-nação costumam fazer parte de uma política mais ampla de promoção da cultura nacional no exterior e de fortalecimento da influência exercida por uma nação sobre as outras (soft power). Esses programas são adotados por diversos países, entre eles França, Holanda, Israel e Brasil, cujo programa de bolsas de tradução da FBN tem por objetivo divulgar a literatura brasileira no exterior. Na direção oposta, as políticas de tradução de estados-nação promovem a tradução de obras estrangeiras para a língua nacional a fim de atingir objetivos educacionais e científicos, como ocorre com os países árabes. A tradução também pode desempenhar uma função econômica. Embora o lucro não seja a única motivação dos editores, em casos de extrema liberalização do mercado livreiro, como ocorre nos Estados Unidos, as obras literárias podem constituir nada mais do que produtos comerciais, como bem ilustra a fabricação de best-sellers mundiais.

Além disso, a tradução pode desempenhar uma função cultural. Sapiro e Heilbron (2009, p. 20) identificam dois polos de circulação de textos: um polo de grande produção, representado pelas obras comerciais, como os best-sellers, e um polo de "produção restrita", como identificado por Bourdieu, representado pelas obras da chamada alta literatura, cuja produção tem rotatividade lenta, visa ao longo prazo e tem por objetivo a constituição de um acervo. Ao contrário da literatura comercial, a alta literatura não é lucrativa do ponto de vista econômico, mas tem valor cultural, estético e intelectual, e representa um investimento em obras que podem vir a se tornar 
clássicos. É no polo da alta literatura que atua o programa de bolsas da FBN, procurado para financiar obras de pouco apelo comercial, já que a publicação de autores com boa vendagem dispensa esse tipo de auxílio. Vale a pena destacar que, enquanto na literatura comercial há claro predomínio da língua inglesa, na alta literatura existe uma diversidade linguística acentuada, uma vez que a literatura contribui para a construção de identidades nacionais. Portanto, embora a globalização reforce a produção em larga escala de obras comerciais, os estados-nação, por meio de seus programas governamentais, continuam a desempenhar um papel crucial no mercado mundial de tradução ao financiar a exportação da produção livreira nacional e, em certos casos, como na França, a importação de literatura estrangeira e de obras acadêmicas.

Por fim, ao lado da disseminação de obras literárias, a tradução desempenha um papel importante na circulação internacional de ideias. Embora aparentem circular sem coerções, as ideias são restritas por fatores políticos, econômicos e culturais. A forma mais extrema de restrição é a censura ideológica, mas a decisão de publicar uma obra literária também está sujeita a fatores econômicos, uma vez que há uma preocupação crescente dos editores com o lucro, em detrimento de critérios intelectuais, o que leva a uma forma de censura econômica. Como a tradução representa um custo adicional para a publicação de uma obra, as obras traduzidas estão mais sujeitas à censura econômica do que aquelas escritas na língua nacional de um país; portanto, os programas de bolsas de tradução financiados por diferentes nações têm por objetivo contornar essas restrições econômicas.

\subsection{2.}

\section{Pascale Casanova e a República Mundial das Letras}

Pascale Casanova dedicou grande parte de sua obra à investigação do papel desempenhado pela tradução no universo de trocas literárias internacionais no qual diferentes literaturas e, principalmente, grupos linguísticos disputam prestígio e legitimidade. Considero, portanto, o modelo teórico desenvolvido pela autora adequado para ajudar a explicar as relações de troca entre os vários espaços literários com os quais trabalharei nesta dissertação. 
Casanova desmistifica a visão de que a tradução literária envolveria uma transposição de um texto de uma língua para outra, operando uma troca linguística entre iguais por meio de uma operação simétrica e neutra, entre espaços literários nacionais de mesmo poder. Nesse sentido, os Estudos da Tradução analisariam dois textos ou dois contextos sem nenhuma relação real entre si.

Casanova, ao inverter a perspectiva e situar a prática da tradução no universo das trocas literárias internacionais, percebe que a visão tradicional da tradução impede a avaliação do que está realmente em jogo na circulação internacional de textos literários. A perspectiva transnacional torna aparente as relações hierárquicas e as lutas por poder entre os espaços literários nacionais e revela que "longe de ser uma troca horizontal e uma transferência tranquila, como costuma ser descrita, a tradução deve ser entendida, ao contrário, como uma "troca desigual" que ocorre em um universo altamente hierarquizado" (Casanova, 2010, p. 288). ${ }^{6}$

Para entender as hierarquias linguística e nacional que regem as operações de tradução, antes é preciso descrever a estrutura do espaço literário internacional, que não existiu desde sempre. Esse espaço foi construído a partir do século XVI, quando a literatura, que até então se organizava em grupos regionais fechados em si, sem intercâmbio uns com os outros, viu surgir a luta entre diferentes grupos para assumir uma posição de destaque. O primeiro espaço regional a reivindicar a primazia sobre os demais foi a Itália do Renascimento, em virtude de sua herança latina. No entanto, a França passou a contestar o avanço italiano e a hegemonia latina no intuito de assumir a liderança, o que conseguiu a partir do século XVII. Aos poucos, outros participantes, como a Espanha e a Inglaterra, começaram a desafiar a liderança da França com base em diferentes tradições literárias. Mais tarde, no decorrer do século XIX, os movimentos nacionalistas surgidos na Europa Central, dentre eles o Romantismo alemão, deram origem a novas reivindicações ao direito de existência literária. O século XIX ainda viu a América do Norte e a América Latina entrarem nessa disputa. Por fim, com a descolonização, os países que ainda se encontravam excluídos até mesmo da ideia de uma literatura própria, como ocorria na África, Índia e Ásia, passaram a

6 "far from being the horizontal exchange and peaceful transfer often described, translation must be understood, on the contrary, as an 'unequal exchange' that takes place in a strongly hierarchized universe." 
almejar a legitimidade e a existência literárias (Casanova, 2002, p.25). A interação entre todos esses espaços literários deu origem assim ao espaço literário internacional atual que Casanova chama de República Mundial das Letras.

O espaço literário mundial, formado pela combinação de quase todos os espaços literários nacionais, se estruturou de acordo com o volume de capital literário e com o correlativo grau de autonomia de cada espaço literário nacional. Na República Mundial das Letras, os espaços mais dotados de capital literário também são os mais antigos, ou seja, os que primeiro entraram na concorrência literária e cujos clássicos nacionais são também clássicos universais. Esses espaços são os mais autônomos, ou seja, são aqueles em que a literatura se constrói contra "as reduções ou as instrumentalizações políticas e/ou nacionais" (Casanova, 2002, p. 113). Nesse aspecto, é possível identificar dois polos opostos no espaço literário internacional. De um lado, encontra-se o polo autônomo, constituído pelos espaços literários mais dotados de capital literário, enquanto que, de outro lado, situa-se o polo nacional (ou nacionalista), formado por espaços nacionais emergentes ou privados de capital literário, geralmente dependentes das autoridades políticas nacionais.

Existe uma homologia estrutural entre cada espaço nacional e o espaço literário internacional: os espaços nacionais também são estruturados de acordo com a oposição entre um polo cosmopolita, autônomo e de "vanguarda" literária, e um polo político e nacional voltado para a produção literária local. A posição de cada espaço nacional na estrutura mundial depende do volume de capital por ele acumulado e de sua proximidade de um dos dois polos descritos. O universo literário mundial pode, portanto, ser representado como uma entidade formada pelo grupo inteiro de espaços literários nacionais, que são, por sua vez, bipolares e situados hierarquicamente na estrutura mundial de acordo com o peso relativo que têm o polo internacional e o polo nacional (e nacionalista) de cada espaço (Casanova, 2002, p. 140).

Casanova afirma existir uma distribuição desigual não apenas de capital literário, mas de capital linguístico-literário. Para sustentar sua afirmação, a autora cita o estudo de Abram de Swaan (1993, 2001 apud Casanova, 2010, p. 288-289) que demonstrou a desigualdade política e social das línguas e descreveu o capital linguístico-político. Para o sociólogo holandês, a centralidade de uma língua no 
“sistema linguístico mundial” pode ser medida pelo número de falantes multilíngues que a dominam. Em outras palavras, o número de falantes de uma língua não é suficiente para estabelecer sua centralidade, que só é garantida pelo número de poliglotas capazes de se comunicar por meio dela. Casanova tentou mostrar que esse capital não está associado apenas a uma língua, mas também a um capital literário, ou linguístico-literário. Esse capital está relacionado ao prestígio e ao valor literário atribuídos a uma língua, que, por sua vez, depende de fatores a ela associados como: antiguidade, refinamento de suas formas literárias, tradições, dentre outros.

Ao investigar o capital linguístico-literário, a autora propõe substituir o binômio "centro-periferia" - adotado por Gisélè Sapiro e Johan Heilbron em suas análises, e cujas implicações Casanova considera meramente espaciais ou hierárquicas - pela oposição entre "dominante-dominada", que implica uma estrutura de dominação e luta por poder. Em vez de opor línguas centrais a línguas periféricas, a autora confronta línguas dominantes e dominadas. Casanova propõe medir o volume de capital linguístico-literário de uma língua não pelo número de seus escritores ou leitores, mas pelo número de poliglotas literários que a usam e pelo seu número de tradutores literários, profissionais imprescindíveis para a circulação de textos entre línguas. A distribuição desigual de capital configura o campo linguístico-literário em uma oposição entre línguas literárias dominadas e línguas literárias dominantes. As línguas dominadas são aquelas que foram nacionalizadas (isto é, se tornaram línguas nacionais) há pouco tempo, desfrutam de capital literário limitado, contam com pouco reconhecimento internacional, dispõem de um pequeno número de tradutores nacionais, ou internacionais, ou são pouco, ou nada, conhecidas nos grandes centros literários. Dentre essas línguas podemos citar como exemplo o próprio português, que conta com reconhecimento internacional restrito e número reduzido de tradutores. As línguas dominantes são dotadas de capital literário relativamente grande devido a seu prestígio, antiguidade e volume de textos considerados universais escritos originalmente nessas línguas. Neste grupo, podemos citar o francês, que se tornou uma língua nacional já por volta do século XVI e conta com grande número de obras consideradas universais. 
Ainda de acordo com a autora, as línguas dominadas não constituem um conjunto homogêneo e podem ser divididas em quatro grupos. O primeiro grupo abrange as línguas ágrafas. Por não possuírem um sistema de escrita, essas línguas são privadas de capital literário, não conseguem se beneficiar de traduções e são desconhecidas no espaço literário internacional. Podemos incluir as línguas ameríndias nesse grupo. O segundo grupo inclui as línguas com breve história de uso, por exemplo, aquelas criadas ou recriadas recentemente após a independência política, como o hebraico e o catalão. Essas línguas dependem bastante da tradução para estabelecer um corpus literário e penetrar o mercado internacional. Elas contam com poucos falantes e textos e são usadas por um número reduzido de poliglotas. Ao promover a tradução, essas línguas podem conquistar uma presença internacional. O terceiro grupo é composto por línguas tradicionais usadas em pequenos países com poucos falantes, como, por exemplo, o holandês e o grego. Essas línguas têm prestígio e história considerável, mas contam com número reduzido de falantes e poliglotas e são pouco reconhecidas fora das fronteiras nacionais, isto é, possuem valor literário limitado no mercado internacional. Por último, o quarto grupo consiste em línguas com grande número de falantes e tradições literárias consideráveis que não são valorizados no mercado literário mundial, como o chinês, o árabe e o português.

Casanova identifica quatro cenários possíveis de tradução e afirma que o significado da tradução em cada um deles depende não só da posição das línguas de partida e de chegada, como também do autor e do tradutor. São estes os cenários possíveis: (i) tradução de uma língua dominante para uma língua dominada; (ii) tradução de uma língua dominada para uma língua dominante; (iii) tradução de uma língua dominante para outra língua dominante; e (iv) tradução de uma língua dominada para outra língua dominada. Os cenários nos quais Casanova está interessada são os dois primeiros (2002).

O primeiro cenário é descrito pela autora como uma forma de acumulação de capital literário, que ocorre quando, para competir no espaço literário internacional, escritores de campos literários dominados "nacionalizam", ou seja, traduzem, obras consideradas de valor universal. Assim, a tradução de obras de literaturas dominantes funciona como uma forma de importação de capital literário. Casanova (2010, p. 290- 
1) cita como exemplo dessa estratégia de tradução o período do Romantismo na Alemanha. A Alemanha demorou a constituir uma identidade nacional, se comparada a outras nações europeias, portanto, o alemão foi, durante muito tempo, uma língua dominada. Como consequência dessa situação, no final do século XVIII e durante a primeira metade do século XIX, os alemães instituíram uma estratégia coletiva de apropriação da literatura e da filosofia greco-romanas da Antiguidade por meio da tradução dos clássicos para o alemão. Essa estratégia permitiu aos alemães formar uma tradição que eles não possuíam por acumulação inicial de capital literário e representou uma oportunidade de rivalizar com nações de mais prestígio literário, notadamente a França, cujos clássicos nacionais contavam com o reconhecimento internacional. A conquista de capital literário foi reforçada pelo trabalho de linguistas e filólogos que contribuíram com seu conhecimento especializado na luta contra a dominação da língua francesa. Os estudos comparativos de gramática elevaram a língua germânica ao mesmo nível de nobreza do grego e do latim, ao situá-la em posição central na família de línguas indo-europeias. Essa visão da língua germânica como uma língua nobre e elevada levou ao desenvolvimento de uma teoria da tradução específica dos estudiosos alemães da época. Para reforçar o esforço coletivo no sentido de adquirir capital literário, era necessário declarar as traduções francesas de textos do grego e do latim obsoletas e, portanto, teorizar sobre o que seria a "verdadeira tradução". A teoria e a prática alemãs da tradução foram baseadas em uma oposição firme e precisa à tradição francesa. Portanto, enquanto as traduções francesas, à época, eram realizadas sem a menor preocupação com a "fidelidade" ao texto fonte, as traduções alemãs advogavam o princípio da "fidelidade".

O segundo cenário ao qual Casanova se refere diz respeito à tradução como forma de consagração, que ocorre quando um autor ou uma obra de uma literatura dominada penetra um centro literário dominante. Essa operação depende dos agentes envolvidos no processo, dentre eles o próprio tradutor. A tradução de autores dominados é um ato que concede a eles "visibilidade literária" em um processo no qual obras e autores adquirem, segundo Casanova (2002, p. 37), prestígio e capital linguístico-literário. Como afirma a autora: 
A transmutação mágica operada pelos grandes consagradores é uma mudança de natureza para os textos vindos de regiões literariamente deserdadas: uma passagem da inexistência à existência literária, da invisibilidade ao estado de literatura, transformação aqui chamada literarização. (2002, p. 162)

A desigualdade linguístico-literária implica em que o valor literário de um texto, ou seja, seu valor no mercado de bens literários, dependa, ao menos em parte, da língua em que foi escrito. De acordo com Casanova, essa desigualdade tem efeitos tão fortes que pode impedir, ou pelo menos dificultar, o reconhecimento ou a consagração de escritores de línguas dominadas. É possível observar essa situação, por exemplo, na dificuldade que os escritores de língua portuguesa encontram de penetração no mercado internacional de bens literários. Temos muito poucos autores consagrados internacionalmente e, até o momento, um único autor da língua portuguesa, José Saramago, foi agraciado com a maior honraria literária mundial, o Prêmio Nobel.

Para um escritor de língua dominada, lutar para ser traduzido é, de fato, lutar pela própria existência como um membro legítimo da República Mundial das Letras, é lutar por acesso aos principais centros literários, às autoridades de crítica e consagração, é lutar pelo direito de ser lido por aqueles que decidem o que vale a pena ser lido.

Quando uma obra é traduzida para uma das grandes línguas literárias, ela é legitimada. A tradução, nesse caso, se torna um tipo de direito à existência internacional. Ela permite ao escritor não apenas ser reconhecido como uma figura literária fora das fronteiras de seu país, mas até mesmo conquistar uma posição autônoma no universo nacional no qual se insere.

O tradutor também é um agente essencial no modelo apresentado por Casanova. A posição de um texto traduzido (ou de um autor) e, portanto, seu grau de legitimidade, decorre, muitas vezes, da posição do tradutor (Casanova, 2010, p. 299). Como a tradução é uma das formas de transferência de capital literário, o valor de uma tradução e seu grau de legitimidade dependem do capital do próprio agente consagrador, o tradutor, e do capital linguístico-literário da língua meta (ao qual deve ser acrescentado o capital da editora, o prestígio da série ou do periódico no qual o texto foi publicado etc.). Em outras palavras, é possível deduzir o grau de legitimidade da obra traduzida a partir da posição do tradutor no campo nacional, da posição da língua meta e da 
posição da editora da obra traduzida. Quanto maior for o prestígio do tradutor, mais "nobre" será a tradução e seu poder de consagração.

Essa é, portanto, uma breve descrição do modelo teórico desenvolvido por Pascale Casanova $(2002$, 2010) para dar conta do universo de trocas literárias internacionais composto pelos diferentes espaços literários que interagem por meio, principalmente, da tradução e que aqui será adotado para explicar as forças que atuam nas trocas transnacionais possibilitadas pelo programa de bolsas de tradução da FBN. 


\section{2. \\ Estratégias da FBN para a promoção da literatura brasileira no exterior}

Este capítulo é dedicado à descrição e análise das estratégias adotadas pela FBN para a promoção da literatura brasileira no exterior, como a participação da instituição em feiras internacionais, a fim de divulgar obras e autores nacionais; o incentivo à participação de autores brasileiros em eventos e feiras literárias fora do território nacional; a edição e distribuição no exterior de antologias, catálogos e outras publicações bilíngues de apresentação da literatura produzida no Brasil; a entrega de prêmios literários concedidos pela instituição, mais uma forma de incentivar autores nacionais; e, por último, a cessão de bolsas de tradução de obras brasileiras a editoras estrangeiras.

\section{1.}

\section{A participação em feiras literárias internacionais}

As feiras literárias internacionais representam uma grande oportunidade de exposição da literatura de um país a editoras e profissionais do meio editorial mundial, no intuito de interessá-los na publicação de obras e autores de uma literatura específica em seus respectivos países. Tais feiras funcionam como um espaço de trocas simbólicas (Bourdieu, 2007, p. 14) entre os mais diversos agentes do sistema literário mundial em que os representantes de um país interagem, em uma ponta, com editores e agentes literários do mercado editorial nacional e, em outra ponta, com editores, agentes literários e tradutores estrangeiros, estabelecendo uma rede de contatos com esses agentes de patronagem essencial para a difusão de uma literatura no exterior. No entanto, a presença de um país periférico como o Brasil nas principais feiras literárias em que são negociados títulos de todo o mundo é uma entre centenas, o que exige um grande esforço de divulgação por parte dos representantes brasileiros para que a nossa literatura se destaque. Além da dificuldade imposta pela concorrência com as literaturas dos demais países, o Brasil precisa superar também o obstáculo representado 
pela falta de contato da maioria dos autores brasileiros com editoras estrangeiras e, por vezes, até com um agente literário no exterior. Por esses motivos, é importante que o país conte com o suporte de patronos que apoiem as letras nacionais, papel desempenhado por vários agentes culturais, dentre eles o governo federal brasileiro, representado, principalmente, pela FBN.

Em colaboração com instituições das esferas pública e privada, como a Secretaria Especial da Cultura (anteriormente, Ministério da Cultura), o Ministério das Relações Exteriores, as embaixadas do Brasil no exterior, a Câmara Brasileira do Livro (CBL) e o Sindicato Nacional dos Editores de Livros (SNEL), a FBN vem participando de inúmeras feiras literárias internacionais, prestando um apoio complementar ao trabalho das editoras brasileiras e dos agentes literários interessados em divulgar no exterior as obras dos autores que representam.

Dentre as participações brasileiras em feiras internacionais, cabe destacar aquelas em que o Brasil foi o país homenageado, como a Feira do Livro de Frankfurt, em 1994 e 2013, e o Salão do Livro de Paris, em 1998 e 2015, entre outras. Para Karine Pansa, ex-presidente da Câmara Brasileira do Livro (CBL), ser o país homenageado em uma feira internacional de prestígio, como a Feira do Livro de Frankfurt, que funciona como um grande centro de comercialização de direitos autorais, representa:

1. Oportunidade única de mostrar a cultura do país no exterior; 2. Destaque para produção editorial no mundo; 3. Grande exposição na mídia internacional; 4. Oportunidades de crescimento dos negócios, não apenas com a Alemanha, mas mundialmente (Pansa apud Pardo, 2013).

Quadro 1: Feiras literárias e salões internacionais nos quais o Brasil participou como homenageado.

\begin{tabular}{|l|l|}
\hline Feira & Ano da homenagem ao Brasil \\
\hline Feira do Livro de Frankfurt, Alemanha & 1994 \\
\hline Feira Internacional do Livro de Bogotá, Colômbia & 1995 \\
\hline Feira Internacional do Livro Infantil de Bolonha, Itália & 1995 \\
\hline Salão do Livro de Paris, França & 1998 \\
\hline Feira do Livro de Guadalajara, México & 2001 \\
\hline Feira do Livro de Santiago, Chile & 2007 \\
\hline Feira do Livro de Santo Domingo, República Dominicana & 2008 \\
\hline Feira do Livro de Lima, Peru & 2009 \\
\hline
\end{tabular}




\begin{tabular}{|l|l|}
\hline Feira Internacional do Livro de Bogotá, Colômbia & 2012 \\
\hline Feira do Livro de Frankfurt, Alemanha & 2013 \\
\hline Feira Internacional do Livro Infantil de Bolonha, Itália & 2014 \\
\hline Feira do Livro de Gotemburgo, Suécia & 2014 \\
\hline Salão do Livro de Paris, França & 2015 \\
\hline
\end{tabular}

Fonte: Elaborado pela autora da dissertação com base em dados coletados nos relatórios de gestão da FBN (2021)

A fim de atestar a importância da homenagem em uma feira internacional para a difusão da literatura brasileira no exterior e medir o interesse dos agentes do campo literário e editorial na nossa literatura, podemos tomar como exemplo a relação de obras contempladas com bolsas do programa de tradução da FBN antes e depois da Feira do Livro de Frankfurt de 2013. De acordo com dados de uma planilha cedida pela coordenação do programa de bolsas de tradução, constatamos que, até 2012, as editoras alemãs não demonstravam grande interesse pelo programa. Em 2011, foram requisitadas somente seis bolsas. Já em 2012, como preparação para a Feira do Livro de Frankfurt, esse número saltou para 22 bolsas. Em 2013, ano da homenagem ao Brasil, foram solicitadas 36 bolsas, um aumento de cerca de 84\% em relação a 2011. Já em 2014, após a feira, o número de bolsas concedidas caiu para um total de 10. Esses números demonstram a importância da homenagem ao Brasil em uma feira literária internacional para a circulação da literatura brasileira fora do território nacional e para a exportação de nossos talentos literários. No caso particular da Feira do Livro de Frankfurt de 2013, é importante destacar ainda que o acordo entre o governo brasileiro e os organizadores da feira incluía uma cláusula especificando a necessidade de se criar ou reforçar um programa de apoio à tradução de obras da literatura brasileira. A FBN aproveitou a oportunidade para fortalecer seu programa de bolsas, que já existia desde 1991, mas de forma muito discreta. O resultado do acordo entre o governo brasileiro e a Feira de Frankfurt foi um grande aumento no número de bolsas solicitadas por editoras estrangeiras.

Embora as homenagens em feiras sejam uma ótima oportunidade para que a literatura e os autores de um país conquistem destaque em um universo bastante competitivo, o investimento nessas participações especiais é muito alto, o que leva alguns países a recusarem a homenagem. Além disso, há o entendimento por parte dos 
gestores do programa de internacionalização da literatura da FBN de que as participações em feiras precisam ter continuidade e, mais importante do que ser homenageado em uma feira, é estar presente em todas as suas edições do evento (Lima; Salgado, 2015, s.p.).

As feiras também podem ser percebidas como "espaços de uma nova diplomacia, do tipo cultural, e de ações de soft power ('poder brando') para os diferentes sistemas literários nelas representados, em geral, por países e editoras" (Pardo, 2014, s.p.). O soft power é entendido atualmente como um outro modo de relacionamento entre as nações, baseado no poder de sedução de um país, sua cultura, suas ideias e sua diplomacia (diferentemente do poder militar, ou hard power). Assim, podemos caracterizar a presença do Brasil nas mais diversas feiras internacionais do livro na atualidade como uma ação de política cultural e diplomática, e considerar os autores que integram as comitivas representativas do país como embaixadores capazes de contribuir para construir uma imagem atual da cultura brasileira.

As feiras internacionais do livro funcionam como um espaço de lutas para atingir posições mais centrais no cenário editorial mundial, com ampla repercussão internacional para escritores, editores, tradutores e agentes literários bem como para as instituições que representam um país. A própria distribuição física dos espaços atribuídos pelos organizadores nas feiras, seja por país, editora, setor do mercado editorial, agência literária etc., responde a regras e interesses que denunciam o caráter periférico de certos sistemas literários, como analisou Sorá (2003) no caso da Feira do Livro de Frankfurt. Nesse cenário, a partir da virada do milênio, o Brasil passou a buscar maior protagonismo mundial, o que culminou, por exemplo, com a candidatura do país para sediar eventos internacionais como a Copa do Mundo de Futebol da FIFA, em 2014, e os Jogos Olímpicos do Rio de Janeiro, em 2016. Essa política visava atingir posições de maior centralidade no espaço internacional. Nesse momento, os agentes políticos e econômicos brasileiros - respondendo a uma iniciativa do governo federal à época de implementação de uma política de Estado acima das oscilações de futuros governos- passaram a dar maior importância à literatura brasileira como parte da indústria cultural e, portanto, produto para exportação e, ao mesmo tempo, instrumento para construir a imagem do país no exterior, junto com outros produtos culturais, dentre 
os quais se destacam a música, o cinema, o artesanato e a moda. $\mathrm{O}$ governo brasileiro aproveitou a conjuntura favorável no cenário internacional para mostrar a cultura brasileira no seu conjunto, e investiu pesadamente na divulgação de sua produção literária em feiras do livro por intermédio do programa de internacionalização da literatura da FBN.

Em resumo, as feiras literárias internacionais são espaços em que os países colocam em prática estratégias de diplomacia cultural e de soft power - por meio de homenagens em que figuram como convidados de honra, de programas culturais e literários, de programas de apoio à tradução etc. - no intuito de acumular capital, seja ele literário, cultural ou simbólico, que contribua para melhorar sua posição e seu nível de legitimação/consagração no cenário literário internacional.

\section{2.}

\section{Programa de Intercâmbio de Autores Brasileiros no Exterior}

Em conversas com editores, agentes literários e tradutores estrangeiros, os responsáveis pelo programa de internacionalização da literatura brasileira da FBN, Fabio Lima e Moema Salgado, perceberam que esses agentes sentiam a necessidade de contar com apoio também para convidar autores interessados em participar de palestras, lançamentos de livros e outros eventos organizados no exterior, a fim de promovê-los e, consequentemente, divulgar a própria literatura brasileira (Lima; Salgado, 2015, s.p.). É importante destacar que, desde seu lançamento em 1991, o programa de internacionalização da FBN convidou autores brasileiros para tomar parte na representação brasileira em feiras literárias internacionais diversas vezes. No entanto, essas participações não bastavam para promover um autor brasileiro fora do território nacional. Foi pensando em tornar mais constante a presença de autores brasileiros em eventos literários no exterior, portanto, que a FBN, complementando seu programa de internacionalização da literatura brasileira, lançou o Programa de Intercâmbio de Autores Brasileiros no Exterior. Esse programa contou, até o momento, com três editais, publicados nos anos de 2012, 2014 e 2016, sendo que este último constitui o Anexo A desta dissertação. 
Conforme seu edital, o programa tem por objetivo difundir a cultura e a literatura brasileiras por meio da concessão de recursos financeiros a editoras e instituições culturais estrangeiras a fim de financiar, parcial ou integralmente, o custeio de despesas de transporte, interurbano e/ou internacional, relacionadas à participação de autores brasileiros em eventos literários no exterior. Para participar do programa, a editora precisa ter adquirido para publicação os direitos autorais de uma obra de autor brasileiro, e ter interesse em promover a participação do autor em eventos literários internacionais. Além de editoras, também podem receber o auxílio agentes culturais estrangeiros, como festivais e feiras literárias, interessados em organizar atividades com autores brasileiros ou convidá-los para períodos de residência no exterior. Os autores beneficiados pela bolsa devem ter publicado no Brasil ao menos um livro nas áreas de literatura e humanidades, especialmente nos seguintes gêneros: romance, conto, poesia, crônica, infantil, juvenil, história em quadrinhos, teatro, obra de referência, ensaio literário, ensaio social ou ensaio de vulgarização científica.

De acordo com os editais publicados até o momento, ao ser aprovada pela FBN, a editora ou instituição cultural recebe apoio financeiro de mil e quinhentos dólares americanos e, caso os gastos com transporte sejam inferiores ao valor do apoio concedido, o proponente pode utilizar o saldo em outras despesas necessárias à participação do autor no evento. Os editais determinam ainda que a seleção dos projetos inscritos seja realizada por uma comissão avaliadora constituída por: (i) dois representantes da FBN; (ii) um representante do Ministério da Cultura ou de instituição vinculada; (iii) um representante do Ministério das Relações Exteriores; e (iv) um especialista em literatura e/ou tradução, geralmente selecionado entre os pesquisadores da Fundação Casa de Rui Barbosa. A comissão avaliadora adota como critérios: (i) a contribuição das atividades desenvolvidas para a divulgação da literatura e da cultura brasileiras; (ii) a importância da promoção do autor em eventos literários no exterior para a divulgação da literatura e da cultura brasileiras; e (iii) a consistência e a capacidade de execução da agenda de eventos proposta pela editora ou instituição estrangeira.

De 2012 a 2017, a FBN concedeu 132 bolsas de intercâmbio a autores brasileiros no exterior, conforme mostra o quadro 2. São destaques nessa lista centros 
culturais hegemônicos, como Alemanha e França, além de Portugal e de alguns dos nossos vizinhos latino-americanos, como o México e a Argentina.

Quadro 2: Países e autores contemplados no Programa de Intercâmbio de Autores Brasileiros no Exterior da FBN, no período de 2012 a 2017.

\begin{tabular}{|c|c|c|}
\hline País & $\mathrm{N}^{\circ}$ de bolsas & Autores beneficiados \\
\hline Alemanha & 29 & $\begin{array}{l}\text { André Sant'Anna, Fernando Molica, Ferréz, Lourenço } \\
\text { Mutarelli, Marcelino Freire, Raimundo Carrero, Ana Paula } \\
\text { Maia, João Paulo Cuenca, Mayra Dias Gomes, Beatriz } \\
\text { Bracher, Luiz Ruffato (4x), Ronaldo Wrobel, Adriana } \\
\text { Lisboa, Rogério Duarte, Andréa del Fuego, Paulo Lins, } \\
\text { Flávia Lins e Silva, Luis Krausz, Edney Silvestre, André de } \\
\text { Leones, Antônio Xerxenesky, Olavo Amaral, Paloma } \\
\text { Vidal, Tércia Montenegro, Daniel Galera, Bernardo } \\
\text { Kucinski }\end{array}$ \\
\hline México & 29 & $\begin{array}{l}\text { Ignácio de Loyola Brandão, Paula Parisot, Ana Paula Maia, } \\
\text { André de Leones, Antônio Xerxenesky, Beatriz Bracher, } \\
\text { Bernardo Ajzenberg, Carol Bensimon, Carol Rodrigues, } \\
\text { Claudia Lage, Deonísio da Silva, Emílio Fraia, Flávio } \\
\text { Carneiro, Ivana Arruda Leite, Joca Reiners Terron, José } \\
\text { Luiz Passos, Julián Fuks, Juliano Garcia Pessanha, Luisa } \\
\text { Geisler, Marcelino Freire, Marcelo Ferroni, Noemi Jaffe, } \\
\text { Paulo Scott, Raphael Montes, Rubens Figueiredo, Sérgio } \\
\text { Caparelli, Sérgio Rodrigues, Simone Campos, Joca Reiners } \\
\text { Terron }\end{array}$ \\
\hline França & 17 & $\begin{array}{l}\text { Ana Paula Maia, Bernardo Carvalho, Edyr Augusto, João } \\
\text { Almino, João Paulo Cuenca, Luiz Ruffato, Marcelino } \\
\text { Freire, Patrícia Melo, Paulo Lins, Raimundo Carrero, Ana } \\
\text { Paula Maia, Edney Silvestre, Lourenço Mutarelli, Manoela } \\
\text { Sawitzki, Ferréz, Marçal Aquino, Rodrigo Ciríaco }\end{array}$ \\
\hline Portugal & 13 & $\begin{array}{l}\text { Lélia Parreira Duarte, Luiz Ruffato, Rinaldo Gama, } \\
\text { Daniela Arbex, André Neves, Ângela Lago, Ciça Fittipaldi, } \\
\text { Nelson Motta, Reinaldo Moraes, Ricardo Azevedo, Roger } \\
\text { Mello, Ruy Castro, Sidarta Ribeiro }\end{array}$ \\
\hline Argentina & 10 & $\begin{array}{l}\text { Altair Martins, Ricardo Lísias, Ronald Augusto, Regina } \\
\text { Dalcastagnè, Andréa del Fuego, Bernardo Carvalho, }\end{array}$ \\
\hline
\end{tabular}




\begin{tabular}{|c|c|c|}
\hline & & $\begin{array}{l}\text { Ronald Augusto, Ana Maria Machado, Rodrigo Savazoni, } \\
\text { Marcelino Freire }\end{array}$ \\
\hline Reino Unido & 7 & $\begin{array}{l}\text { Edney Silvestre, Angélica Freitas, Tatiana Salem Levy, } \\
\text { Ricardo Lísias, Michel Laub, Antônio Moura, Bernardo } \\
\text { Kucinski }\end{array}$ \\
\hline Croácia & 5 & $\begin{array}{l}\text { Ferréz, João Anzanello Carrascoza, Ana Paula Maia, João } \\
\text { Anzanello Carrascoza, João Paulo Cuenca }\end{array}$ \\
\hline Espanha & 4 & $\begin{array}{l}\text { Santiago Nazarian, Ilan Brenman, Frei Betto, Rubens } \\
\text { Figueiredo }\end{array}$ \\
\hline Itália & 4 & $\begin{array}{l}\text { Betty Mindlin, Ronaldo Wrobel, José Castello, José } \\
\text { Custódio Rosa Filho }\end{array}$ \\
\hline Estados Unidos & 2 & Adélia Prado, Ana Maria Gonçalves \\
\hline Uruguai & 2 & Daniel Munduruku, Maurício Negro \\
\hline Áustria & 1 & Daniel Munduruku \\
\hline Finlândia & 1 & Paulo Lins \\
\hline Grécia & 1 & Vassiliki Thomas Constantinidou \\
\hline Hungria & 1 & André Sant'Anna \\
\hline Irlanda & 1 & Ana Maria Machado \\
\hline Israel & 1 & João Gilberto Noll \\
\hline Peru & 1 & Paulo Franchetti \\
\hline Romênia & 1 & Wladimir Queiroz \\
\hline Sérvia & 1 & Adriana Lisboa \\
\hline Suécia & 1 & Guilherme Mallon \\
\hline
\end{tabular}

Fonte: Elaborado pela autora da dissertação com base em dados disponibilizados pela FBN (2021)

A julgar pelo número de bolsas concedidas, conclui-se que o programa obteve grande aceitação. O último edital do programa foi publicado em 2016 e ainda não há previsão de um novo edital, mas, de acordo com informações do coordenador, Fabio Lima, obtidas em troca de e-mails, a meta é restabelecer o programa assim que possível.

\section{3.}

\section{A publicação de antologias e catálogos especializados}

Os catálogos e as antologias de obras e autores também são imprescindíveis para a promoção da literatura brasileira no exterior. Como são muitos os países que 
fazem parte do espaço literário internacional, editores, agentes literários, tradutores e outros profissionais do livro nem sempre conhecem muito bem a literatura de um país, principalmente de um país periférico, como é o caso do Brasil, portanto, além da exposição em feiras literárias internacionais, é necessário editar catálogos ou outras publicações de apresentação dos autores e das obras. Como veremos a seguir, ao longo dos quase trinta anos do projeto de divulgação da nossa literatura no exterior, a FBN publicou inúmeros catálogos de obras nacionais e verdadeiras antologias de autores brasileiros, contribuindo para a formação de cânones da literatura brasileira que influenciaram as escolhas de editores e outros profissionais do mercado editorial em todo o mundo, já que, juntamente com as instituições acadêmicas e o mercado editorial, a FBN é capaz de influenciar fortemente a valorização de determinadas obras (e seus autores), alçando-os a uma categoria de grandeza que as torna dignas de serem estudadas por sucessivas gerações. Isso porque, como abordado no capítulo 1, endosso o posicionamento de que as obras não se tornam canônicas por um certo valor intrínseco que possuam, mas por terem sido alçadas a essa categoria por instituições ou agentes dos meios acadêmicos, literários e editoriais em condições de determinar quais obras literárias devem ser lidas, relidas e estudadas. Essa introdução deve servir como alerta para o fato de que os catálogos e as antologias da FBN não abrigam todos os possíveis talentos das nossas letras. Na verdade, essas publicações encerram escolhas fundamentadas em critérios que refletem as posições da FBN. Ao ser publicada em um dos catálogos ou antologias da FBN, é como se uma obra recebesse o aval da instituição, um status que influenciará a escolha das editoras estrangeiras que decidirem publicar um autor nacional. É no sentido de esclarecer que tipo de cânone (ou cânones) a FBN tentou reforçar no exterior que o presente trabalho apresentará - e, quando possível e adequado, comentará - uma relação das publicações voltadas para o mercado externo que foram lançadas pela instituição durante todo o período de existência do projeto de divulgação da literatura brasileira no exterior, ou seja, de 1991 até os dias de hoje.

Logo no primeiro ano do projeto, a FBN lançou, na Feira do Livro de Frankfurt de 1991, a Brazilian Book Magazine, uma revista bilíngue sobre a literatura brasileira, editada em português e inglês, com tiragem de cinco mil exemplares, publicada pela 
própria instituição, com ampla distribuição a consulados e embaixadas do Brasil bem como a agentes literários, editores e livreiros estrangeiros, enfim, todos aqueles que poderiam exercer um papel relevante para a internacionalização da nossa literatura. Esse periódico teve vida longa, sendo publicado de 1991 a 2001. As publicações bilíngues, principalmente no par português-inglês, são uma maneira de superar as barreiras derivadas da escrita em português, uma língua não hegemônica da qual partem menos de $1 \%$ de todas as traduções que compõem o mercado internacional, no qual o inglês, que responde por uma participação de cerca de $60 \%$ do total de traduções como língua de origem, ocupa uma posição hipercentral (Sapiro, 2014, p. 85).

Em 1992, o segundo ano do projeto, a instituição ampliou sua atuação. Além da participação nas feiras internacionais, a FBN esteve presente no II Encontro Internacional de Agentes Literários, realizado durante a Bienal do Livro de São Paulo, que reuniu 11 agentes estrangeiros e três brasileiros. A relevância do encontro deveuse à importância dos agentes literários na promoção de uma literatura ou de um autor junto a editoras estrangeiras, colaborando para que estas se interessem pela publicação de uma obra ou de um autor específico. A partir de uma sugestão ouvida no Encontro, a FBN passou a veicular, quinzenalmente, um clipping de notícias sobre a literatura brasileira publicadas na imprensa nacional com os principais lançamentos editoriais, a fim de manter informados os interessados em nossa literatura no exterior. Essa publicação era distribuída entre agentes literários, departamentos de literatura brasileira em universidades europeias e americanas, centros de estudos brasileiros, livreiros, tradutores e setores afins.

Em 1994, o Brasil viria a ser o país homenageado na Feira do Livro de Frankfurt, o evento mais importante do gênero. Portanto, como preparação para esse acontecimento, em 1993, a FBN participou do I Encontro Internacional de Jornalismo Literário, em Manaus, que reuniu editores de suplementos literários de vários países, com o objetivo de aproximá-los da literatura brasileira. Nesse encontro, foi distribuído o catálogo Brazilian Authors Translated Abroad, um levantamento das obras de ficção (adulta e infantojuvenil) e de teoria literária de autores brasileiros traduzidos no exterior. Esse catálogo foi organizado em cinco colunas com títulos em inglês contendo as seguintes informações: $1^{\mathrm{a}}$ coluna: Original title; $2^{\mathrm{a}}$ coluna: New title (título atribuído 
à obra traduzida); $3^{\mathrm{a}}$ coluna: Translator; $4^{\mathrm{a}}$ coluna: Language (língua de chegada da tradução); 5a coluna: Locality, publishing house, year. Como os demais catálogos publicados nesse período pela FBN, esse não tinha o propósito de apresentar obras ou autores, mas apenas oferecer uma relação de tudo o que já havia sido traduzido da literatura brasileira até então nos mais diversos países, talvez para facilitar o acesso a informações sobre as obras brasileiras disponíveis em língua estrangeira. No mesmo ano, foram elaborados também o Catálogo de ciências sociais e o Catálogo do romance brasileiro, ambos preparados para serem lançados, em edição bilíngue (portuguêsinglês), na Feira do Livro de Frankfurt. Cabe destacar ainda a publicação da Agenda permanente da literatura brasileira, em inglês e português. A pedido de personalidades ligadas à Feira do Livro de Frankfurt, foi preparada ainda a Biobibliografia de autores brasileiros. Contando com cerca de cem autores brasileiros, essa obra, ao contrário dos catálogos, tinha o objetivo de apresentar os autores brasileiros aos profissionais do mercado editorial internacional. Em uma época em que não se contava com a internet, toda a informação sobre autores e obras da literatura produzida no Brasil que circulava nos meios editoriais internacionais era dependente de publicações como as lançadas pela FBN, daí a importância das iniciativas da instituição para a divulgação da nossa literatura no exterior. Pelo número de publicações lançadas pela FBN em 1993, podese medir a importância que representa ser o país homenageado na Feira do Livro de Frankfurt em termos de prestígio e visibilidade que essa homenagem acarreta. Complementando os catálogos já lançados, a FBN publicou em 1994, em coedição com a Universidade Federal Fluminense, Ouvrages brésiliens traduits en France, mais um catálogo de obras e autores brasileiros, dessa vez em francês, de autoria de Estela dos Santos Abreu. Essa obra teve uma atualização publicada em 2008 pela Academia Brasileira de Letras, mas nunca foi reeditada pela FBN.

Não há registro de que a FBN tenha atualizado seus catálogos até 2002, quando a instituição lançou o Guia conciso de autores brasileiros, compilado por Alberto Pucheu e Caio Meira, obra que, por sua natureza, merece uma análise mais minuciosa. Esse guia parece ter o objetivo de conjugar as funções de catálogo e antologia, não se resumindo meramente a listar obras e autores, como ocorria com os catálogos anteriores publicados pela FBN. O Guia conciso destina duas páginas a cada um dos 
182 autores relacionados. A uma página em português, segue-se uma página traduzida para o inglês de mesmo conteúdo. Cada uma dessas páginas inclui a apresentação de um autor, uma crítica especializada, um fragmento de uma de suas obras, uma relação de obras publicadas por ele e informações de contato com o editor que o representa. Dessa publicação constam os mais diversos autores: de escritores do século XVI, como o padre Manuel da Nóbrega e José de Anchieta, aos clássicos do século XIX, como Machado de Assis; dos modernistas do século XX, como Oswald de Andrade, aos ficcionistas contemporâneos, como Milton Hatoum, em uma seleção que inclui romancistas, poetas, críticos literários, dramaturgos, filósofos, historiadores, sociólogos e antropólogos, oferecendo em suas páginas um vasto painel da nossa literatura e ciências sociais. Essa antologia contribuiu para a formação de cânones da literatura brasileira no exterior ao influenciar as escolhas de editores estrangeiros por ela orientados. Para compor essa publicação, a FBN contou com a contribuição de diretores de bibliotecas públicas, críticos e professores que indicaram os autores imprescindíveis para a formação de uma biblioteca básica da literatura brasileira. Além das mais de 300 páginas dedicadas aos autores brasileiros e respectivas obras, o Guia oferece um catálogo de editoras brasileiras e outro de agentes literários de autores brasileiros. Embora o objetivo dos organizadores tenha sido ampliar continuamente a publicação, não há registros de que ele tenha contado com alguma outra edição além da inicial de 2002.

Em 2004, dois anos depois da edição do Guia conciso, o Conselho de Pesquisa em Literatura da FBN selecionou 20 obras, de autores diferentes, cujos primeiros capítulos foram traduzidos para o inglês, o francês e o espanhol, formando três volumes que foram distribuídos em eventos literários internacionais. Essas coletâneas foram publicadas, nos anos de 2004 e 2005, com o título de Seletas de textos. Delas constavam autores clássicos, como Lima Barreto; modernistas, como Graciliano Ramos e José Lins do Rego; e contemporâneos, como Adriana Lisboa, Marçal Aquino e Paulo Henriques Britto.

Seguiu-se a essas publicações um intervalo que durou até 2011, quando a FBN voltou a publicar uma antologia voltada para os agentes do mercado editorial estrangeiro: a obra Clássicos brasileiros: uma seleção de autores com obras em 
domínio público. Esse guia, elaborado já visando a Feira do Livro de Frankfurt de 2013, quando o Brasil viria a ser homenageado mais uma vez, incluiu 50 autores com obras em domínio público e, nas palavras do presidente da FBN à época, Galeno Amorim, foi um "convite para uma viagem histórica pela nossa literatura, em sentido amplo, desde suas origens, no século XVI, até as primeiras décadas do século XX" (Amorim, 2011, p 7). A organização da obra segue o mesmo formato estabelecido para o Guia conciso, ou seja, uma breve apresentação do autor, um fragmento de uma de suas obras, uma crítica especializada e uma relação de suas principais obras. Esse guia também foi lançado em edição única e nunca relançado.

Quadro 3: Antologias e catálogos publicados pela FBN para divulgar a literatura brasileira no exterior.

\begin{tabular}{|l|l|}
\hline Título da publicação & Data da publicação \\
\hline Brazilian Book Magazine & $1991-2001$ \\
\hline Notícias de literatura brasileira (clipping) & $1992-1997$ \\
\hline Catálogo de ciências sociais / Social sciences catalog & 1993 \\
\hline Catálogo do romance brasileiro / Brazilian novel catalog & 1993 \\
\hline Agenda permanente da literatura brasileira & $1993-1994$ \\
\hline Biobibliografia de autores brasileiros & 1993 \\
\hline Brazilian Authors Translated Abroad & $1993-1994$ \\
\hline Ouvrages brésiliens traduits en France & 1994 \\
\hline Guia conciso de autores brasileiro / Brazilian authors concise guide & 2002 \\
\hline Seleta de textos / Selected texts & $2004-2005$ \\
\hline Clássicos brasileiros: uma seleção de autores com obras em domínio público / & 2011 \\
\hline Brazilian classics: a selection of authors with works in public domain & \\
\hline Revista Machado de Assis / Machado de Assis Magazine & $2012-2015$ \\
\hline
\end{tabular}

Fonte: Elaborado pela autora da dissertação com base em dados coletados nos relatórios de gestão da FBN. (2021)

No ano seguinte, no primeiro dia da Feira do Livro de Frankfurt de 2012, a FBN lançou, em parceria com o Itaú Cultural, a Imprensa Oficial de São Paulo e o Itamaraty, o primeiro número de um novo periódico voltado para o mercado editorial externo, com o propósito de apresentar autores e obras aos editores estrangeiros, denominado Machado de Assis Magazine: Brazilian Literature in Translation. A publicação incluía 
fragmentos de obras de autores brasileiros em inglês, espanhol e, por vezes, alemão ou francês (dependendo da língua do país-sede, Alemanha ou França, em cuja feira literária o Brasil seria homenageado), e, de 2012 a 2015, quando sua publicação foi descontinuada, contou com edições impressas semestrais e edições virtuais trimestrais. De modo a compor um panorama abrangente de nossa literatura, os textos publicados no periódico representavam uma ampla gama de épocas, estilos e assuntos, apresentando ao mercado editorial internacional escritores clássicos, autores contemporâneos experientes e novos talentos que vinham se destacando no país tanto na prosa, quanto na poesia. Cada número da revista incluía cerca de 20 textos literários em prosa e verso, bem como: (i) dados sobre a obra em que o texto fora originalmente publicado; (ii) referências sobre publicações da obra no exterior (se aplicáveis); (iii) informações sobre o autor e sua obra; (iv) breve biografia do tradutor; e (v) status dos direitos autorais da obra.

Uma análise dos números da revista nos leva às seguintes constatações: (i) os autores clássicos contam com várias traduções para outros idiomas sem o apoio das bolsas da FBN, mas as editoras estrangeiras ainda parecem depender bastante das bolsas da FBN para publicar autores contemporâneos; (ii) a revista publicou predominantemente textos em língua inglesa (provavelmente por ser o inglês a língua hipercentral por excelência), embora também tenha incluído textos em espanhol em todos os números e, eventualmente, alemão e francês; (iii) a prosa recebeu bem mais atenção do que a poesia, que se restringiu à publicação de alguns nomes, como Eucanaã Ferraz, Geraldo Carneiro, Rodrigo Garcia Lopes e Cecília Meirelles; (iv) Portugal é o país que mais publica autores da língua portuguesa, confirmando o intenso intercâmbio cultural entre as duas nações, facilitado pelo fato de os dois países adotarem a mesma língua oficial.

Editores, agentes literários e os próprios autores reconheceram a Machado de Assis Magazine como uma oportunidade única de conquistar visibilidade no exterior por meio de uma publicação internacional de qualidade disponível gratuitamente para o público em geral. O interesse por parte dos autores brasileiros de constar da publicação ficou evidente na seleção para a inclusão nos números da revista. Por exemplo, de acordo com a própria revista, no segundo número, houve a inscrição de 
147 textos em inglês, espanhol e alemão, dos quais foram selecionados apenas 20, pouco mais de $13 \%$ do total. A seleção dos textos ficou a cargo do conselho editorial da revista, indicado pelo presidente da FBN e formado por professores universitários, editores e representantes das instituições envolvidas no projeto, como mostrado no quadro 4. Em um balanço da fase inicial do projeto, empreendido em 2013, os editores observaram que o periódico "se tornou uma importante plataforma de apoio à negociação de direitos autorais no exterior" (Machado de Assis Magazine, 2013, s. p.). ${ }^{7}$ Prova do êxito alcançado pela revista foi o tráfego registrado em seu portal durante o primeiro ano de existência: cem mil visitantes e 12,3 mil downloads de textos.

Quadro 4: Membros do conselho editorial da Machado de Assis Magazine.

\begin{tabular}{|c|c|c|}
\hline Conselheiro & $\begin{array}{l}\mathrm{N}^{0} \text { da revista em } \\
\text { que atuou }\end{array}$ & Perfil profissional \\
\hline Aníbal Bragança $(1,2)$ & $1,2,3$ & $\begin{array}{l}\text { Representando a FBN, o editor e professor } \\
\text { aposentado da UFF lançou as seguintes obras } \\
\text { Francisco Alves: o rei do livro (EdUSP), Livraria } \\
\text { Ideal: do cordel à bibliofilia (EdUFF) e Impresso no } \\
\text { Brasil: dois séculos de livros brasileiros (Editora da } \\
\text { Unesp). }\end{array}$ \\
\hline Berthold Zilly & $1,2,3,4,5$ & $\begin{array}{l}\text { Professor de instituições como Freie Universitat } \\
\text { Berlin, Universitat Bremen, Universidade Federal do } \\
\text { Ceará e Universidade Federal de Santa Catarina, } \\
\text { traduziu clássicos latino-americanos e portugueses } \\
\text { como Civilización y barbárie, de Domingo F. } \\
\text { Sarmiento, Os sertões, de Euclides da Cunha, } \\
\text { Memorial de Aires, de Machado de Assis e Confissão } \\
\text { de Lúcio, de Mário de Sá Carneiro. No momento, } \\
\text { dedica-se à tradução comentada de Grande sertão: } \\
\text { veredas, de Guimarães Rosa. }\end{array}$ \\
\hline $\begin{array}{l}\text { Carlos Roberto de } \\
\text { Abreu Sodré }\end{array}$ & $1,2,3,4,5$ & $\begin{array}{l}\text { Foi chefe de gabinete da Imprensa Oficial do Estado } \\
\text { de São Paulo (Imesp) }\end{array}$ \\
\hline Charles Perrone & $1,2,3,4,5$ & $\begin{array}{l}\text { Tradutor e professor de português e de literatura e } \\
\text { cultura luso-brasileira na Universidade da Flórida, } \\
\text { EUA. Pesquisa a obra de poetas brasileiros modernos } \\
\text { e contemporâneos como Paulo Leminski, Waly } \\
\text { Salomão, Carlito Azevedo, Cláudia Roquette-Pinto e } \\
\text { Antônio Cícero, dos quais é também tradutor. }\end{array}$ \\
\hline Claudiney Ferreira & $1,2,3,4,5,6,7$ & $\begin{array}{l}\text { Jornalista, radialista, produtor e gestor cultural, com } \\
\text { passagens por revistas do Grupo Abril, Fundação } \\
\text { Roberto Marinho, TV Cultura, BBC de Londres e } \\
\text { CBN e atuação destacada no Instituto Itaú Cultural. }\end{array}$ \\
\hline
\end{tabular}

\footnotetext{
7 "has become an important platform providing support for the negotiation of translation rights
} abroad". 


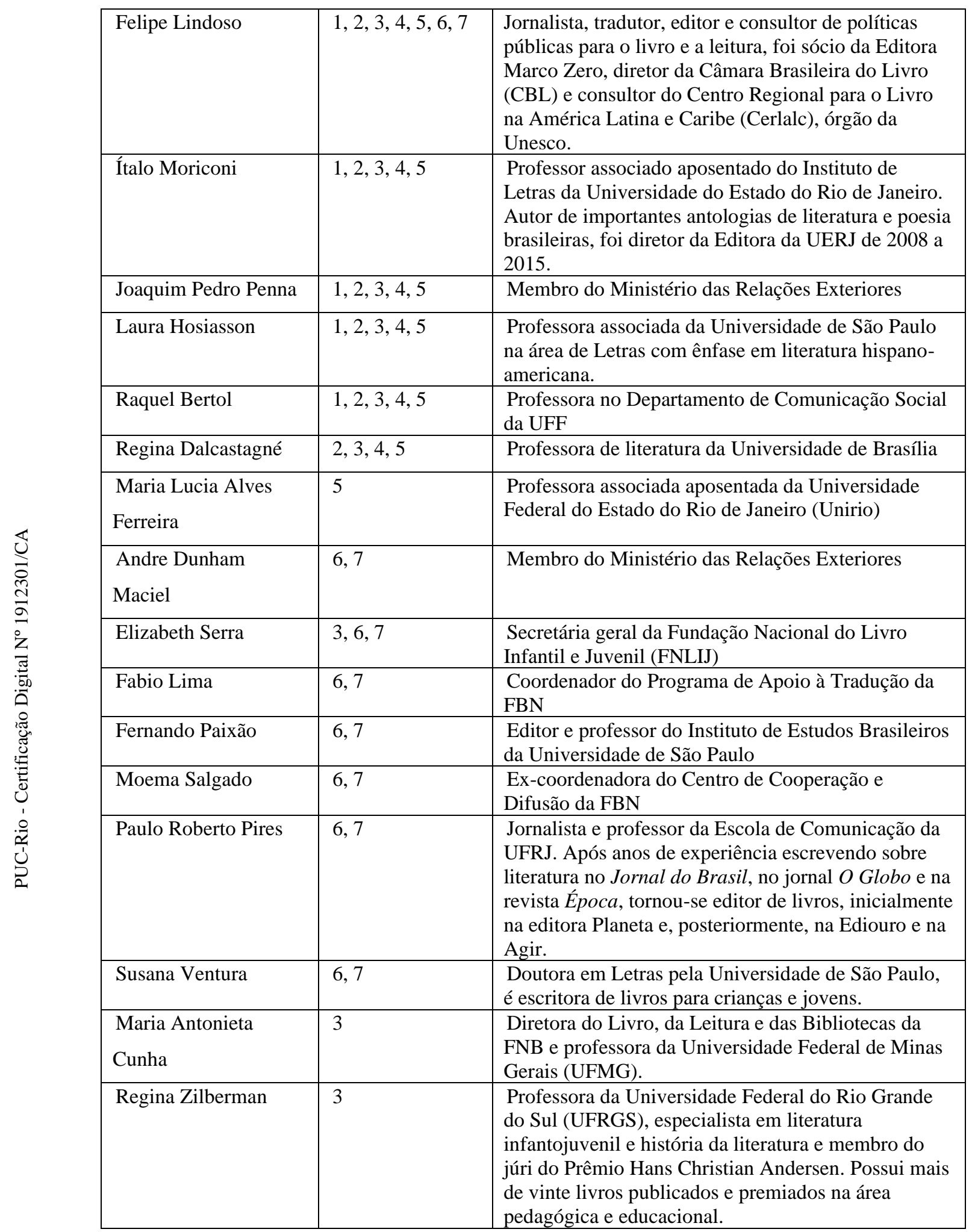

Fonte: Elaborado pela autora da dissertação com base na Machado de Assis Magazine (2021) 
A publicação contou com um número dedicado a um gênero específico: a literatura infantojuvenil. O número 3, lançado em 2013, foi divulgado na Feira do Livro Infantil e Juvenil de Bolonha, a mais importante no seu gênero, como preparação para a homenagem ao Brasil, na própria feira, que ocorreria no ano seguinte, 2014. Esse segmento do mercado é particularmente significativo para o país, uma vez que duas autoras brasileiras já receberam o prêmio Hans Christian Andersen, considerado o Nobel do gênero: em 1982, o prêmio foi concedido a Lygia Bojunga, enquanto em 2000, Ana Maria Machado foi a vencedora. Apesar da importância e da qualidade dos trabalhos dos autores brasileiros de literatura infantil e juvenil, poucos textos foram traduzidos. O objetivo do número 3 da Machado de Assis Magazine foi, portanto, tentar preencher essa lacuna, proporcionando aos leitores nativos de outras línguas a possibilidade de se familiarizar com a nossa rica literatura infantojuvenil. O conselho editorial desse número contou com profissionais especificamente voltados para a produção editorial desse segmento em particular, como Elizabeth Serra, secretária geral da Fundação Nacional do Livro Infantil e Juvenil (FNLIJ), e Regina Zilberman, membro do júri de uma das edições do Prêmio Hans Christian Andersen, como já mencionado. Esse número também destaca os ilustradores, importantes colaboradores dos escritores de literatura infantojuvenil.

A partir do quarto número, além de abrigar ficção, a revista passou a contar com textos de não ficção, uma vez que a participação do Brasil em questões internacionais à época (2013) justificava o interesse pela realidade de nosso país. Foram incluídos nas diversas edições textos como um trecho de Rim por rim, livro reportagem do jornalista Julio Ludemir sobre a venda de órgãos humanos; de Elite da tropa, obra ficcional escrita em parceria entre o antropólogo Luiz Eduardo Soares e os ex-policiais André Batista e Rodrigo Pimentel, baseada nas experiências acumuladas na polícia desses últimos; de Repressão e resistência: censura a livros na ditadura militar, da professora e pesquisadora Sandra Reimão; ou de A longa viagem da biblioteca dos reis, de Lilia Moritz Schwarcz, Angela Marques da Costa e Paulo Cesar de Azevedo, obra sobre a biblioteca real de Portugal, transladada para o Brasil por ocasião do estabelecimento da corte portuguesa em terras brasileiras, dando origem à Biblioteca Nacional. 
Em 2015, a publicação de novos números foi interrompida, de acordo com Fabio Lima, subeditor da revista e coordenador do programa de traduções, em função de dificuldades operacionais após o término da parceria com o Itaú Cultural. No entanto, todos os números da revista encontram-se disponíveis no portal da $\mathrm{FBN}^{8}$. A edição online permite a editores, agentes literários e scouts fazer o download dos textos e das informações sobre os respectivos autores e detentores dos direitos autorais.

As publicações abordadas nesta seção constituem a relação completa de obras da FBN voltadas para a promoção da literatura brasileira junto a editores estrangeiros, agentes literários, tradutores e outros profissionais da academia e do meio editorial envolvidos na patronagem das nossas letras. Embora seja importante reconhecer o esforço que a instituição vem empreendendo com o objetivo de internacionalizar nossa literatura, cabe chamar a atenção para a falta de continuidade de muitas das publicações que deveriam ser periódicas, mas que acabam sendo publicadas apenas por um breve período de tempo, quando não em edição única.

\section{4.}

\section{Os prêmios literários}

Os prêmios literários podem contribuir enormemente para o desenvolvimento de uma literatura nacional, tendo reflexos positivos sobre os autores premiados, as obras consagradas, as editoras que apostam nos projetos laureados e sobre o próprio público leitor. Um prêmio literário favorece o autor ao: (i) concorrer para que este acumule capital literário; (ii) divulgar sua obra entre o grande público; (iii) colaborar para a sua autonomia financeira em decorrência do valor do prêmio, caso este seja pago em dinheiro; e (iv) provocar o aumento das vendas das obras, o que gera o pagamento de direitos autorais ao escritor. Além disso, o prêmio confere prestígio e visibilidade, ou seja, capital simbólico, à editora que publica o livro vencedor, e serve como guia aos leitores ao orientá-los para obras e autores bem avaliados por um corpo de jurados

\footnotetext{
${ }^{8}$ https://www.bn.gov.br
} 
qualificado, que costuma ser formado por críticos, professores, acadêmicos e profissionais do mercado editorial.

Entre os prêmios internacionais mais importantes, merecem destaque o Nobel de Literatura (Suécia, desde 1901), o mais prestigioso de todos, o Goncourt (França, desde 1896), o Pulitzer (Estados Unidos, desde 1917), o Man Booker (Inglaterra, desde 1968), o Cervantes (Espanha, desde 1976) e o Camões (Portugal e Brasil, desde 1988). O Brasil conta com 35 prêmios literários, de acordo com a Wikipédia, dentre os quais o mais prestigioso é, sem dúvida, o Prêmio Jabuti, que abordarei em seguida por sua representatividade e repercussão no meio editorial brasileiro. Tratarei também dos prêmios relacionados à FBN, que, além de conceder um conjunto de prêmios literários da própria instituição, representa o Brasil no Prêmio Camões.

\subsection{1.}

\section{Prêmio Jabuti}

Os primeiros Prêmios Jabuti foram entregues no final do ano de 1959, em solenidade simples e despretensiosa, que laureou o autor Jorge Amado na categoria "Romance", pela obra Gabriela, cravo e canela, e a Saraiva na categoria "Editora do Ano". Nos anos subsequentes, passaram a ser distribuídos sete prêmios nas seguintes categorias: "Literatura", “Capa", "Ilustração", "Editor do Ano", "Gráfico do Ano", "Livreiro do Ano" e "Personalidade Literária". De lá para cá, ao longo de seus 62 anos de existência, o Jabuti passou por profundas transformações e, com o tempo, o número de categorias aumentou. Atualmente, o Jabuti é concedido a 20 categorias distribuídas em quatro eixos distintos, além do prêmio de "Livro do Ano", conforme mostrado no quadro 5. 
Quadro 5: Eixos e categorias do Prêmio Jabuti com respectivos anos de lançamento.

\begin{tabular}{|c|c|}
\hline Eixo & Categorias \\
\hline Literatura & $\begin{array}{l}\text { "Conto" (1997), "Crônica" (2018), "História em Quadrinhos" (2017), "Literatura } \\
\text { Infantil" (1959), "Literatura Juvenil" (1959), "Poesia" (1959), "Romance Literário" } \\
\text { (1959), "Romance de Entretenimento" (2020) }\end{array}$ \\
\hline Ensaio & $\begin{array}{l}\text { "Artes" (2011), "Biografia, Documentário e Reportagem" (2019), "Ciências" (2018), } \\
\text { "Ciências Humanas" (1964), "Ciências Sociais" (2020), "Economia Criativa" (2018) }\end{array}$ \\
\hline Livro & "Capa" (1960), "Ilustração" (1959), "Projeto Gráfico" (2007), "Tradução" (1962) \\
\hline Inovação & "Fomento à Leitura" (2018), "Livro Brasileiro Publicado no Exterior" (2017) \\
\hline
\end{tabular}

Fonte: Elaborado pela autora da dissertação com base em dados disponibilizados pela organização do Prêmio Jabuti (2021)

De acordo com o mais recente edital, podem concorrer ao Prêmio Jabuti: (i) obras publicadas no ano anterior à premiação, no caso do eixo "Literatura", ou publicadas a qualquer tempo, no caso do eixo "Livro"; (ii) somente obras publicadas em língua portuguesa no Brasil; (iii) autores brasileiros natos, ou estrangeiros com residência permanente no país; (iv) obras inscritas por editora, autor, ilustrador, tradutor, capista, produtor gráfico, gráfica ou agente literário; salvo na categoria "Livro Brasileiro Publicado no Exterior", cujas obras devem ser inscritas por editora brasileira, editora estrangeira ou agente literário, não sendo aceitas obras inscritas por autores.

As obras inscritas são analisadas em uma única fase por um corpo de três jurados especialistas nas áreas em questão. Os nomes para a composição do corpo de jurados podem ser indicados pelo mercado editorial, por leitores e por interessados, mediante consulta pública realizada ao longo do ano da premiação. As indicações ao júri são avaliadas pelo curador do prêmio e pelo conselho curador, composto atualmente por quatro integrantes, que verificam a veracidade das informações e selecionam os componentes. Para participar do júri, o jurado: (i) não pode possuir vínculo exclusivo com editora ou autor, obra ou iniciativa inscrita em qualquer categoria; (ii) não pode ter nenhum grau de parentesco com inscritos; (iii) não deve conhecer a identidade dos outros jurados, que só é divulgada publicamente pela Câmara Brasileira do Livro (CBL) após a verificação e a validação das notas. 
Os jurados são responsáveis por selecionar treze livros dentre os inscritos na categoria que julgam e atribuir a eles notas necessariamente diferentes. Os dez livros que obtêm a melhor pontuação passam a constituir os dez pré-finalistas e, dentre estes, são escolhidos, também de acordo com a pontuação, os cinco finalistas. A obra vencedora do prêmio é aquela que conquista a melhor pontuação dentre todas.

Os autores e as editoras envolvidas com a obra vencedora recebem o troféu Jabuti. Além do troféu, o autor recebe um prêmio em dinheiro no valor de cinco mil reais. Caso a obra seja uma coautoria, o prêmio em dinheiro é dividido entre os autores. Cabe ressaltar que não há prêmio em dinheiro para a categoria "Livro Brasileiro Publicado no Exterior".

O prêmio "Livro do Ano", considerado o mais importante, é concedido à obra que obtém a maior nota entre as categorias dos eixos "Literatura" e "Ensaios". Os autores vencedores da premiação são contemplados com um prêmio em dinheiro, cujo valor atual é de cem mil reais, e com uma estatueta especial do Jabuti. As editoras da publicação também recebem uma estatueta especial do Jabuti. Esse prêmio já suscitou uma grande polêmica no ano de 2010, uma vez que o diretor do Grupo Editorial Record, Sergio Machado, criticou a escolha de Leite derramado, romance de Chico Buarque, lançado pela Companhia das Letras, como "Livro do Ano", por acreditar que a premiação seguiu "critérios políticos" (Maia, 2010, s.p.). O executivo argumentou que a obra Se eu fechar os olhos agora, do jornalista Edney Silvestre, publicada pela Record, venceu a categoria "Romance", batendo Leite derramado, segundo colocado, portanto, não faria sentido a obra de Buarque vencê-la em outra disputa com a participação dos dois romances. Essa, no entanto, não é a primeira vez em que o "Livro do Ano" foi entregue a uma obra não vencedora em sua categoria de origem. Em 2004, por exemplo, o próprio Chico Buarque havia levado o maior troféu do Jabuti com Budapeste, que foi apenas o terceiro colocado na categoria "Romance". Isso ocorre porque o júri das duas fases não é o mesmo: quando analisa as categorias específicas, o júri é formado por especialistas na categoria que julgam; na votação do "Livro do Ano", além de participarem da eleição todos os jurados do Jabuti, também são convidados a votar editores e livreiros ligados à CBL (Sereza, 2020, s.p.). 
Vale destacar a categoria "Livro Brasileiro Publicado no Exterior", criada em 2017, de particular interesse a todos que desejam mapear os agentes de patronagem envolvidos na circulação da literatura brasileira fora de nossas fronteiras, uma vez que premia livros de autores brasileiros publicados no exterior em primeira edição no ano anterior à concessão do prêmio. Essa categoria não tem por objetivo premiar o autor, mas sim a editora brasileira que vendeu os direitos autorais de uma obra e a editora estrangeira que comprou e publicou em primeira edição, com tiragem mínima de mil exemplares, o livro brasileiro. Essa categoria, torna-se, assim, um incentivo a mais ao editor estrangeiro interessado em publicar literatura brasileira. Tal categoria tenciona também tornar o Prêmio Jabuti mais conhecido no exterior, agregando prestígio à iniciativa e relevância à literatura brasileira no exterior. A categoria conta com o apoio do Brazilian Publishers - projeto de fomento às exportações de conteúdo editorial brasileiro, resultante da parceria firmada entre a CBL e a Agência Brasileira de Promoção de Exportações e Investimentos (Apex-Brasil), subordinada ao Ministério das Relações Exteriores. A análise das obras concorrentes é focada nas estratégias de lançamento, promoção, comercialização e divulgação da obra, sendo utilizados no julgamento dos candidatos os seguintes critérios: (i) estratégias de promoção e divulgação no exterior; (ii) contribuição para a disseminação da cultura ou literatura do país; e (iii) estratégia de distribuição.

Quadro 6: Editoras agraciadas com o Prêmio Jabuti na categoria "Livro Brasileiro Publicado no Exterior", por ano de premiação, obra e autor

\begin{tabular}{|c|c|c|c|}
\hline Ano de premiação & Editoras & Obra & Autor \\
\hline 2017 & $\begin{array}{l}\text { Penguin Random House (RU) / } \\
\text { Companhia das Letras }\end{array}$ & Um copo de cólera & Raduan Nassar \\
\hline 2018 & $\begin{array}{l}\text { Restless Books (EUA) / } \\
\text { Companhia das Letras }\end{array}$ & Fim & Fernanda Torres \\
\hline 2019 & $\begin{array}{l}\text { Charco Press (RU) / Companhia } \\
\text { das Letras }\end{array}$ & A resistência & Julián Fuks \\
\hline 2020 & $\begin{array}{l}\text { Two Lines Press (EUA) / Grupo } \\
\text { Editorial Record }\end{array}$ & Lorde & João Gilberto Noll \\
\hline
\end{tabular}

Fonte: Elaborado pela autora da dissertação com base em dados disponibilizados pela organização do Prêmio Jabuti (2021) 


\subsection{2.}

\section{Prêmios da Fundação Biblioteca Nacional}

A FBN promove a literatura brasileira por meio do fomento a processos de criação, edição, difusão, circulação, intercâmbio e residência literária, utilizando instrumentos como bolsas e prêmios. Em mais uma iniciativa de valorização do autor brasileiro, a instituição criou, em 2005, um conjunto de prêmios literários. Os prêmios literários da FBN, concedidos anualmente, costumam contemplar obras de nove gêneros diferentes, como mostrado no quadro 7. Os prêmios, que homenageiam intelectuais destacados na cultura brasileira, contemplam obras em primeira edição, publicadas no ano anterior à premiação. A FBN exige que todas as obras concorrentes tenham sido publicadas em língua portuguesa por uma editora brasileira, estejam em conformidade com a Lei do Depósito Legal e possuam um ISBN (International Standard Book Number). Em 2020, o vencedor em cada categoria recebeu, em espécie, o valor de trinta mil reais, que, no caso de obra com mais de um autor, foi dividido entre todos os envolvidos.

Quadro 7: Prêmios literários oferecidos pela FBN e respectivos gêneros contemplados

\begin{tabular}{|l|l|}
\hline Prêmio & Gênero \\
\hline Prêmio Alphonsus de Guimaraens & Poesia \\
\hline Prêmio Machado de Assis & Romance \\
\hline Prêmio Clarice Lispector & Conto \\
\hline Prêmio Paulo Rónai & Tradução \\
\hline Prêmio Sérgio Buarque de Holanda & Ensaio social \\
\hline Prêmio Mario de Andrade & Ensaio literário \\
\hline Prêmio Sylvia Orthof & Literatura infantil \\
\hline Prêmio Glória Pondé & Literatura juvenil \\
\hline Prêmio Aloísio Magalhães & Projeto gráfico \\
\hline
\end{tabular}

Fonte: Elaborado pela autora da dissertação com dados disponibilizados pela FBN (2021)

Para avaliar os concorrentes aos prêmios, é constituída uma Comissão Julgadora, formada por três membros escolhidos entre especialistas da área em questão, para cada uma das nove categorias de premiação. Os especialistas podem ser críticos literários com mais de três anos de experiência, professores universitários ou 
profissionais de destaque no meio literário, tradutório ou editorial. Além disso, o profissional precisa ter participado anteriormente de comissão julgadora e possuir notório saber na categoria que julga. A seleção dos jurados leva em conta: (i) formação acadêmica na área da categoria do prêmio; (ii) experiência profissional comprovada na categoria do prêmio; e (iii) atuação semelhante em outros júris literários no Brasil. No ano de 2020, as obras concorrentes foram julgadas de acordo com os critérios exibidos no quadro 8.

Quadro 8: Critérios de avaliação dos prêmios da FBN em 2020.

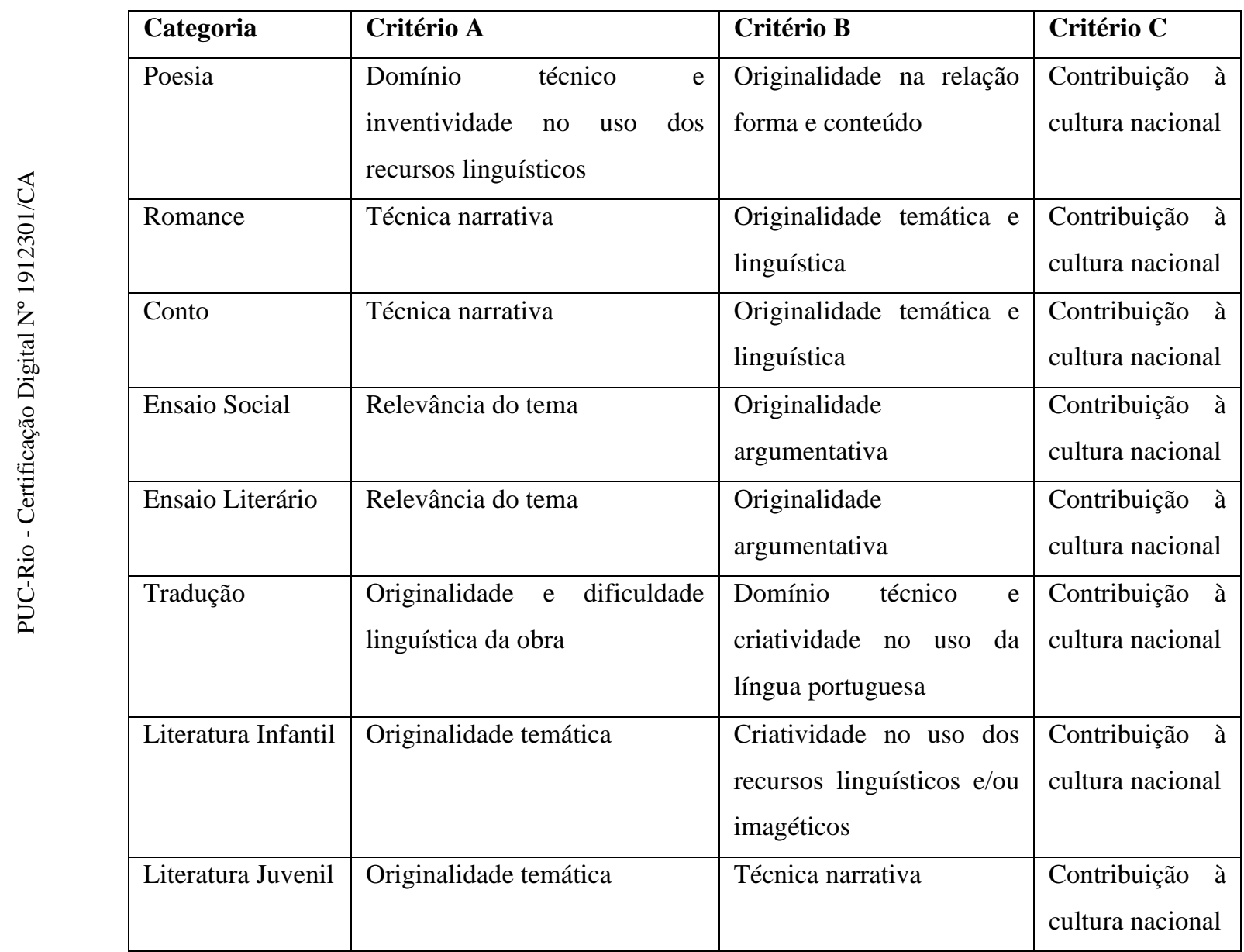

Fonte: Elaborado pela autora da dissertação com base em dados disponibilizados pela FBN (2021)

Excepcionalmente, na edição de 2020, por questões logísticas, o Prêmio Aloísio Magalhães não foi oferecido, uma vez que o recebimento e o encaminhamento dos exemplares à comissão julgadora mostraram-se inviáveis diante do fechamento da FBN 
e da instituição do regime de trabalho remoto de seus funcionários em virtude da pandemia do coronavírus.

\subsection{3.}

\section{Prêmio Camões}

O Prêmio Camões, considerado o mais importante da literatura de língua portuguesa, é concedido pelos governos de Portugal e do Brasil, que se faz representar pela FBN. O Camões é conferido a autores da Comunidade dos Países de Língua Portuguesa (CPLP) que tenham contribuído para o engrandecimento do patrimônio literário e cultural da nossa língua. Instituído em 1988, ele tem como objetivo estabelecer uma conexão intercultural entre os sete países de língua portuguesa. Os autores laureados adquirem grande visibilidade e se tornam conhecidos do público leitor de toda a comunidade lusófona, além disso, o prêmio desperta o interesse de editoras da CPLP que costumam publicá-los no país em que estão estabelecidas. Além disso, com a instituição do Camões, os países da comunidade lusófona passaram a ombrear com as literaturas hispano-americanas que há muito contavam com o Prêmio Cervantes.

Assim como outros prêmios literários, o Camões também já suscitou polêmicas ao longo de sua trajetória. Uma delas diz respeito à nacionalidade dos agraciados com

o prêmio. Embora ele possa ser concedido a qualquer autor da língua portuguesa, é inegável a preponderância dos autores portugueses e brasileiros, uma vez que, até o momento, apenas seis autores africanos foram premiados, contra treze brasileiros e quatorze portugueses, em um total de 32 agraciados, sendo, portanto, notável o desequilíbrio. Como destacou o escritor Jorge Henrique Bastos, essa situação talvez se deva ao "facto destas literaturas serem ainda jovens, e muitas das obras estão ainda em curso para se inserir nos pressupostos que norteiam a atribuição do prémio" (Bastos, 2000, s.p.).

O gênero dos autores premiados também já motivou controvérsias por parte da crítica, uma vez que dos 32 agraciados apenas seis são mulheres, e ainda assim o prêmio atribuído à escritora Raquel de Queiroz, a primeira mulher a receber o galardão, 
gerou polêmica por si só. Isso porque os jurados brasileiros naquele ano, Arnaldo Niskier, Oscar Dias Correia e João de Scantimburgo, foram acusados de terem chegado a Portugal já com a decisão tomada de premiar a escritora, embora os portugueses insistissem em atribuir o prêmio a Jorge Amado. Como cabia aos brasileiros a primazia sobre a decisão naquela edição, Raquel de Queiroz foi a escolhida, o que suscitou entre os portugueses a impressão de um jogo de cartas marcadas. Chegou-se a acusar os jurados brasileiros de terem selecionado a escritora apenas por terem contado com sua boa vontade na eleição para a Academia Brasileira de Letras, da qual ela já era membro, e por estarem unidos a ela por também serem membros da Academia. O escritor português José Carlos Pires chegou a declarar sobre a vencedora: "A sua obra não avaliza a exigência que caracteriza o prêmio" (Jornal do Brasil, 1993, p. 7).

A última controvérsia ocorreu na edição de 2019, quando o presidente Jair Bolsonaro sugeriu que não assinaria o diploma de entrega do Prêmio Camões atribuído ao escritor Chico Buarque, em uma atitude a que o escritor reagiu com a seguinte declaração: "A não assinatura do Bolsonaro no diploma é para mim um segundo prêmio Camões" (G1, 2019, s.p.).

\section{5.}

\section{O programa de bolsas de tradução}

O programa de bolsas de tradução da FBN existe desde 1991, mas em 2011 ele foi expandido e se transformou em um projeto mais amplo denominado Programa de Apoio à Tradução e à Publicação de Autores Brasileiros no Exterior, que contempla não apenas a tradução de obras da literatura brasileira para qualquer língua, mas também a publicação de textos de nossos escritores nos demais países lusófonos. Abordarei neste trabalho apenas as bolsas de tradução uma vez que tenho como um dos meus objetivos observar as disputas por hegemonia entre as diferentes culturas, literaturas e línguas na República Mundial das Letras.

As bolsas constituem um importante instrumento do governo no sentido de difundir a literatura e a cultura brasileiras para além de nossas fronteiras. Essa iniciativa confronta a questão imposta a um editor estrangeiro que, ao optar por publicar uma obra de um autor estrangeiro em vez de uma obra nacional, vê-se diante de uma despesa 
extra: os custos da tradução. O programa de bolsas de tradução da FBN foi desenvolvido justamente para incentivar os editores a publicarem obras brasileiras sem precisar arcar com os custos da tradução, assumidos pela instituição brasileira. Isso significa que uma obra publicada no exterior com o incentivo de uma bolsa de tradução da FBN conta, a princípio, com dupla patronagem (Lefevere, 1992, p. 14): da própria instituição, que arca com os custos da tradução, e da editora estrangeira, que se encarrega das demais despesas relativas à publicação da obra. Além disso, as bolsas de tradução da FBN ajudam a visibilizar a profissão de tradutor da língua portuguesa, oferecendo oportunidades de trabalho e promovendo o intercâmbio entre tradutores e destes com os autores.

\subsection{1.}

\section{A história do programa de bolsas de tradução da FBN}

Após trinta anos de existência, já é possível traçar uma história do programa de bolsas da FBN, que compreende dois momentos: o primeiro abrange os anos de 1991 a 2009, enquanto o segundo engloba o período iniciado em 2010 e segue até 2018, quando os dados relativos a esta pesquisa deixaram de ser coletados. A diferença entre os dois momentos analisados, ou seja, de 1991 a 2009 e de 2010 a 2018, não pode ser desprezada, uma vez que, no primeiro momento, o programa concedeu uma média de 9,4 bolsas por ano; já no segundo momento, a média anual foi de 101,4 bolsas, como constatamos no gráfico exibido um pouco mais adiante. Quanto ao período eleito para a coleta de dados, é preciso esclarecer que muitas das análises elaboradas aqui foram baseadas em uma planilha compilada pela FBN e entregue a mim em 2018, daí a decisão de embasar a pesquisa no período entre 1991 e 2018, sem incluir o biênio 20192020. Essa decisão não me pareceu prejudicar as descobertas da pesquisa, já que 2019 não foi marcado por nenhuma mudança de rumo ou de objetivos do projeto, enquanto 2020 foi um ano em que a instituição pouco avançou com o projeto devido à pandemia, interrompendo, inclusive, as reuniões de avaliação das editoras interessadas em receber o apoio das bolsas de tradução e, como consequência, paralisando a concessão das 
próprias bolsas. De qualquer forma, minha pesquisa inclui 27 anos de projeto, período que já permite fazer um balanço da iniciativa.

O programa começou em 1991, de forma bastante tímida, em função de um convite recebido para ser o Brasil o país homenageado na edição de 1994 da Feira do Livro de Frankfurt - o maior evento literário da atualidade e o principal centro de negociação de direitos autorais do mundo. A princípio, o programa se resumia à concessão de um número bem modesto de bolsas de tradução a editoras estrangeiras interessadas em publicar obras brasileiras, um mecanismo eficaz, que, a exemplo de iniciativas semelhantes de outros países, estimula a difusão da literatura brasileira e ataca as desigualdades do espaço literário internacional, no qual autores das mais diversas nacionalidades disputam as atenções das editoras. O programa veio suprir a necessidade da literatura brasileira de contar com um patrono, de forma a enfrentar as desvantagens observadas na relação com literaturas de culturas hegemônicas. No entanto, foi só a partir de 2010 que a preocupação com a internacionalização da literatura brasileira foi, de fato, incorporada de forma sensível aos esforços da FBN no sentido de projetar a imagem do país no exterior. Em outubro de 2010, o governo brasileiro aceitou participar mais uma vez como convidado de honra da edição de 2013 da Feira do Livro de Frankfurt. Entre as cláusulas do acordo assinado com a organização da feira, estava a recomendação de se estabelecer um fundo de apoio à tradução de obras brasileiras para outras línguas. Esse foi o ponto de partida para expandir e fortalecer as políticas públicas, ainda muito incipientes, de incentivo à difusão da literatura brasileira no exterior. Além do aumento do aporte financeiro, que ampliou consideravelmente o número de iniciativas apoiadas, uma das principais conquistas alcançadas desde então tem sido a manutenção ininterrupta dos editais que regem e viabilizam a concessão de incentivos, garantindo ao programa continuidade, fator decisivo para o sucesso das políticas culturais do Brasil. 
Gráfico 3: Número de bolsas de tradução concedidas pelo programa da FBN entre os anos de 1991 e 2018

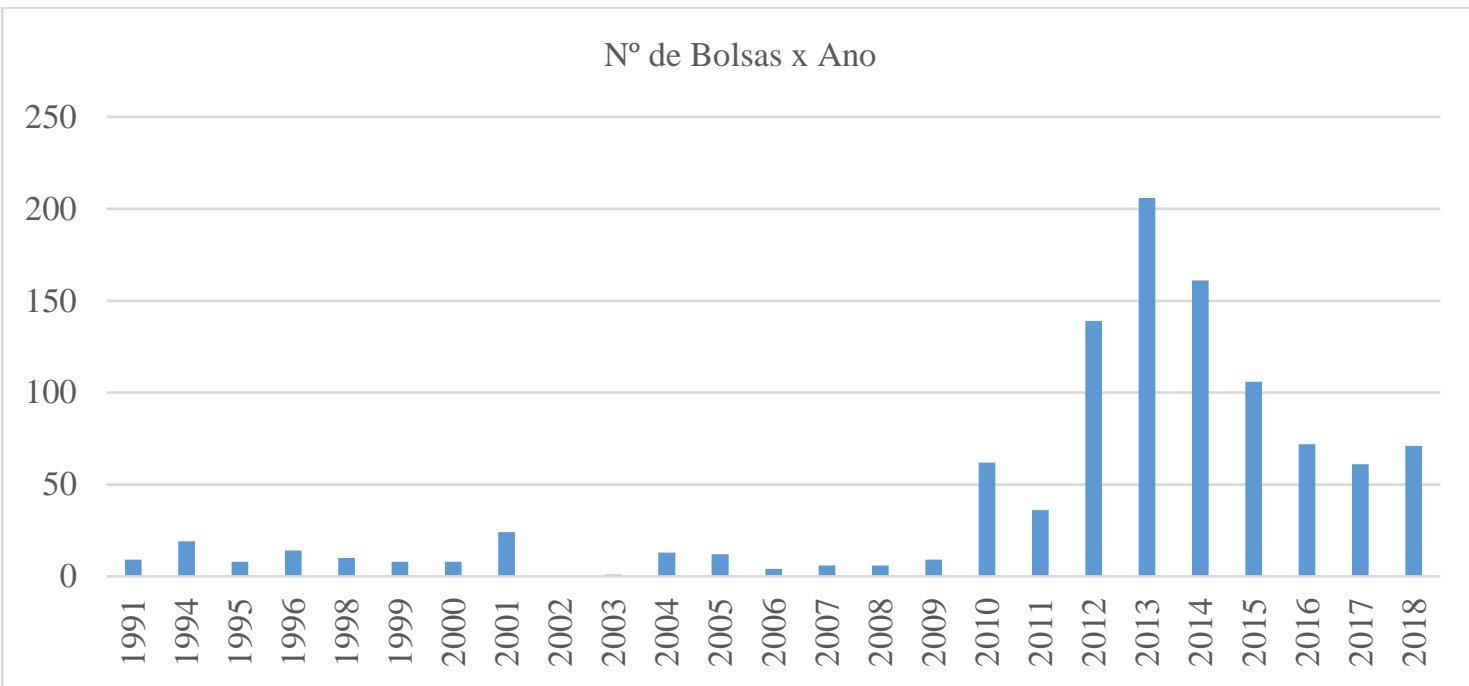

Fonte: Elaborado pela autora da dissertação com base em dados disponibilizados pela FBN (2021)

O programa de bolsas da FBN não é o único em seu gênero, como nos permite inferir Gisèle Sapiro (2014, p. 87) ao destacar casos como o dos Estados Unidos que, na década de 1990, por meio de seu Departamento de Estado, financiou a tradução de obras de pensadores neoliberais em países comunistas. Sapiro cita também exemplos de países em que o apoio à tradução de obras literárias não tem fins ideológicos específicos, mas visa apenas à promoção da cultura nacional no exterior, como ocorre na França, nos Países Baixos e em Israel. Há ainda casos de incentivos na direção oposta, isto é, países que investem em uma política estatal de tradução de obras estrangeiras educacionais ou científicas para a língua nacional a fim de evitar a defasagem no desenvolvimento da ciência doméstica em relação a outras nações e manter a competitividade, como é o caso dos países árabes. O programa da FBN, à semelhança de programas de outros países, não tem fins ideológicos específicos, o que pode ser atestado pela diversidade de obras apoiadas por ele, que financia a tradução de obras tanto de autores pouco conhecidos como de autores já consagrados, como Chico Buarque ou Paulo Coelho, sem impor qualquer restrição de cunho ideológico aos contemplados. 
Cabe destacar a importância que representa para um autor brasileiro ser traduzido, principalmente para a língua de uma cultura hegemônica, caso em que a tradução representa uma forma de consagração, já que um autor de um espaço literário dominado, isto é, de um país cuja literatura conta com pouco reconhecimento internacional, como é o caso do Brasil, é traduzido para a língua de um espaço literário dominante, ou seja, um país cuja literatura desfruta de muito prestígio, como é o caso da França, da Espanha ou da Alemanha. Ao ser consagrado em um grande centro literário por meio da tradução, além da relevância internacional que conquista, um autor passa a contar com maior reconhecimento e conquista mais visibilidade até mesmo em seu próprio país (Casanova, 2002).

\subsection{2.}

\section{As regras de concessão das bolsas de tradução}

As bolsas de tradução são divulgadas por meio de editais bilíngues. Inicialmente, os editais ficavam abertos durante cerca de dois meses, mas, com o tempo, a FBN concluiu que esse formato não atendia adequadamente às editoras estrangeiras, já que os projetos editoriais nem sempre podiam aguardar a abertura de um novo edital. A fim de contornar esse problema, a partir de 2011, o edital passou a ser bienal e permanecer aberto por dois anos sem interrupções. Dessa forma, a editora interessada passou a poder inscrever um projeto editorial no programa e aguardar sua avaliação em uma das reuniões da comissão avaliadora, que ocorrem regularmente ao longo do ano. Esse formato obteve boa aceitação do mercado editorial internacional, tanto que o programa que, a princípio, contava com pouca procura, em 2015 já contabilizava 180 inscrições e 160 bolsas aprovadas (Lima; Salgado, 2015, s.p.).

Foi também a partir de 2011 que a coordenação do programa de bolsas, vinculada ao Centro de Cooperação e Difusão da FBN, começou a tentar entender melhor quais eram as questões a serem resolvidas para que o programa contasse com a adesão das editoras estrangeiras. Problemas aparentemente triviais desencorajavam certos candidatos. Por exemplo, preencher uma ficha de inscrição ou escrever uma carta, em português, exigências do edital, limitavam o interesse das editoras em se 
inscrever, por isso a FBN passou a receber inscrições em inglês, e o edital passou a ser bilíngue. Por outro lado, percebeu-se que a instituição necessitava de certas garantias que não eram cobradas no edital, entre elas, um plano de distribuição da obra traduzida, bem como o contrato e o currículo do tradutor. Houve também um alerta dos órgãos de controle interno, ou seja, a procuradoria e a auditoria, quanto à necessidade de garantir a idoneidade da editora, que passou a ser verificada, se necessário até mesmo pela embaixada local, acionada por meio do Ministério das Relações Exteriores. Por esse motivo, a inscrição passou a ser realizada em duas etapas. A primeira é constituída por uma verificação da documentação exigida e da idoneidade da editora, já a segunda, realizada pela comissão avaliadora, é o julgamento do projeto em si.

$\mathrm{O}$ edital mais recente de oferta de bolsas, que constitui o anexo B desta dissertação, foi publicado em 27 de junho de 2018 e compreendeu o biênio 2018-2020, mas foi estendido por mais 12 meses em virtude da pandemia do coronavírus. De acordo com o edital, o programa destina-se a editoras estrangeiras que desejam traduzir para qualquer idioma, publicar e distribuir, no exterior, em forma de livro impresso ou digital, obras, anteriormente publicadas em português no Brasil, de autores aqui nascidos ou naturalizados brasileiros. Embora as bolsas se destinem a obras já publicadas anteriormente no Brasil, estão previstas exceções para textos inéditos no país, desde que sejam incluídos em projetos de coletâneas de ensaios, contos e poemas, e contem com a aprovação da comissão avaliadora.

O programa de tradução visa a apoiar as editoras estrangeiras interessadas em traduzir e publicar literatura e humanidades, não cabendo ao projeto apoiar trabalhos técnico-científicos. São aceitas obras nos seguintes gêneros: romance, conto, poesia, crônica, literatura infantil, literatura juvenil, história em quadrinhos, teatro, obra de referência, ensaio literário, ensaio social, ensaio de vulgarização científica e antologias de poemas e contos, integrais ou em parte. O programa apoia ainda a tradução de dossiês sobre a literatura brasileira publicados em periódicos literários internacionais.

O programa se propõe a apoiar traduções inéditas, retraduções ou ainda reedições de obras já traduzidas que estejam esgotadas e fora de mercado há pelo menos três anos no país de destino. O apoio visa a financiar, parcial ou totalmente, as despesas de editoras estrangeiras com a tradução de obras de autores brasileiros no exterior e, 
no caso de projetos de tradução de histórias em quadrinhos e de obras da literatura infantil e juvenil, o apoio se estende aos custos de edição e impressão. Nos demais casos, as despesas de edição e impressão também poderão ser custeadas a depender de análise da comissão avaliadora.

De acordo com o último edital do programa, a instituição concede apoio financeiro no valor total de mil a seis mil dólares americanos a projetos de tradução e retradução. No caso de reedições de traduções fora de catálogo, o apoio máximo atinge três mil dólares norte-americanos. Apenas a título de comparação, em 2004, uma pesquisa com tradutores de língua inglesa revelou que a tradução de uma obra de 300 páginas era orçada em cerca de 9 mil dólares norte-americanos (Venuti, 2008, p. 10). Os países de língua inglesa, no entanto, são apenas parte do mercado de tradução atingido pelas bolsas, que pretendem alcançar as mais diversas regiões do mundo, e os valores pagos a tradutores podem variar enormemente de um país para o outro. De qualquer forma, vale lembrar que as bolsas são destinadas ao custeio total ou parcial das despesas das editoras estrangeiras com a tradução. Isso significa que, em certas situações, como no caso do mercado de língua inglesa, presume-se que as bolsas cubram apenas parte dos custos da tradução.

A editora recebe o incentivo da FBN em duas parcelas: a primeira parcela, de $50 \%$ do valor total do apoio, é paga após a assinatura de um termo de compromisso entre a editora e a instituição, portanto, antes da prestação do serviço de tradução; a segunda parcela, os 50\% restantes, é paga após o fornecimento à instituição de cinco exemplares impressos da obra ou mediante a disponibilização do texto em formato digital, ou seja, após o final do projeto.

A FBN exige uma série de documentos visando a garantir que os objetivos propostos no edital sejam alcançados, sem que se desrespeitem os direitos de todos os envolvidos no processo. De acordo com o edital de 2018, é obrigatória a apresentação dos seguintes documentos: (i) carta de apresentação do projeto, justificando a solicitação do apoio; (ii) formulários de inscrição preenchidos $;^{9}$ (iii) cópia do contrato de cessão de direitos autorais firmado entre a editora e o autor; (vi) comprovação da anuência do autor quanto à solicitação da bolsa; (v) cópia do contrato de tradução da

\footnotetext{
${ }^{9}$ Ver Anexo B
} 
obra firmado entre a editora e o tradutor, mencionando o custo da tradução; (vi) currículo do tradutor; (vii) contrato social da editora ou documento equivalente; (viii) catálogo recente de publicações da editora; (ix) tiragem prevista; (x) projeto de distribuição e venda, que inclua as formas de divulgação e os principais canais e pontos de venda, físicos e/ou virtuais, a fim de garantir visibilidade mínima à obra. Esses documentos, em sua maioria, podem ser fornecidos em português, espanhol, francês ou inglês, em mais uma medida que visa a facilitar a inscrição das editoras no programa. Essas exigências garantem a transparência do relacionamento entre a editora, o tradutor, os autores das obras contempladas e a FBN, que aprova não apenas o projeto da editora, mas também o tradutor por ela escolhido, bem como as relações comerciais mantidas entre o autor, a editora e o tradutor.

Ainda de acordo com o edital, o processo seletivo dos projetos é realizado por uma comissão avaliadora constituída por: (i) dois representantes da própria FBN, sendo um deles o presidente da comissão, encarregado de coordenar os trabalhos, presidir as reuniões e emitir voto de qualidade, quando necessário; (ii) dois representantes da Secretaria Especial da Cultura ou de entidades vinculadas; (iii) um representante do Departamento Cultural do Ministério das Relações Exteriores; e (iv) um profissional da área de literatura ou tradução, posição que costumava ser preenchida por um membro da Fundação Casa de Rui Barbosa, instituição de pesquisa, ensino e preservação da memória de personalidades brasileiras. Na composição da comissão avaliadora, observamos a divisão de responsabilidades entre, de um lado, o patrono no caso, o governo federal do Brasil, representado por membros de instituições a ele subordinadas, a quem interessa determinar a ideologia a ser reforçada pelo programa, cujo interesse é divulgar a cultura e a literatura brasileiras ao redor do mundo e, nesse sentido, conquistar para si maior influência nas relações internacionais por meio de soft power - e, de outro lado, um profissional do meio literário, encarregado de julgar o valor estético das obras contempladas (Bassnett; Lefevere, 1992, p. vii). Esse profissional, ao selecionar os projetos a serem beneficiados com a bolsa, decide quais são as obras e os autores merecedores de publicação no exterior e, dessa forma, se torna um dos responsáveis por definir os cânones da literatura brasileira que vigorarão nos 
diferentes sistemas de literatura traduzida ao redor do mundo (Even-Zohar, 1997 [1990], p. 45).

De acordo com o edital do programa de bolsas de tradução, que constitui o Anexo B, a comissão avaliadora adota os seguintes critérios para a seleção de um projeto:

(i) "Importância da publicação da obra para a promoção e a divulgação da cultura e da literatura brasileiras no exterior": entre os fatores a serem considerados na avaliação deste critério, o edital do programa de bolsas cita a "representatividade da obra no campo da literatura e da produção intelectual brasileiras". Esse fator poderia levar à seleção apenas de obras consagradas que já tenham alcançado reconhecimento dentro e fora do país. No entanto, a comissão considera igualmente importante a contribuição da obra contemplada para a diversidade da representação de nossa literatura no exterior, o que permitirá uma maior variedade de obras contempladas e à escolha de autores ainda inéditos fora do Brasil. A comissão deve considerar ainda a contribuição que a obra pode dar à diversidade de gêneros literários representados no quadro geral de projetos apoiados pelo programa de bolsas.

(ii) "Importância estratégica do idioma e do país em que a obra será publicada para a promoção e divulgação da cultura e da literatura brasileiras no exterior": de acordo com este critério, a comissão deve avaliar o "nível de circulação global que a publicação da obra em determinado idioma é capaz de proporcionar". Aqui, vemos uma tendência a contemplar traduções para as línguas de culturas hegemônicas, uma vez que a tradução de uma obra do português para uma língua central, como o inglês, o francês, o espanhol ou o alemão, pode desencadear uma sucessão de traduções para outras línguas, elevando o nível de circulação global da obra (Heilbron; Sapiro, 2007). Por outro lado, o critério também considera a "diversidade que a tradução da obra é capaz de agregar ao quadro geral das línguas e países em que a literatura e a produção intelectual brasileiras já se encontram representadas”. Assim, a instituição parece priorizar países e línguas nos quais nossa literatura está sub-representada ou, até mesmo, não está presente. Para 
atender a esse critério, os avaliadores precisam encontrar um ponto de equilíbrio entre os dois fatores.

(iii) "Relevância da editora proponente no que diz respeito ao catálogo, projeto e meios de promoção e distribuição da obra publicada": para atender a esse critério, é importante analisar o histórico e as condições da editora de arcar com a responsabilidade de levar a cabo o projeto de publicação da obra, incluindo sua promoção e distribuição no mercado alvo. Esse critério tende a priorizar editoras grandes e renomadas, com sólida reputação e maior infraestrutura de divulgação e comercialização de projetos editoriais, garantindo que as obras contempladas com a bolsa atinjam o público leitor. No entanto, os grandes grupos editoriais não são os únicos interessados em traduzir a literatura brasileira. Há pequenas editoras, voltadas para a chamada alta literatura e interessadas no que aqui se produz em termos de literatura, que também têm sua contribuição a dar.

(iv) "Currículo do tradutor": a FBN, por um lado, valoriza a "experiência do profissional na tradução direta de literatura em língua portuguesa para o idioma em questão" e, por outro, admite a participação de tradutores iniciantes. A experiência profissional costuma funcionar como uma garantia de qualidade, mas não há dúvida de que uma língua adquire importância na medida em que conta com grande número de poliglotas capazes não só de se expressar por meio dela, mas também de traduzi-la (Casanova, 2002, p.35). Nesse sentido, é compreensível que a FBN tenha uma certa preocupação com a formação de novos tradutores da língua portuguesa. Para atingir esse objetivo, a instituição vem oferecendo oficinas de tradução, que serão tratadas em detalhes no capítulo 4, e que têm entre seus objetivos formar novos profissionais. Além disso, ao priorizar a tradução direta, a instituição parece estar reforçando sua preocupação em formar tradutores da língua portuguesa para outras línguas além daquelas que detêm maior prestígio mundial. Para atender a esse critério, os avaliadores precisam contemplar tanto profissionais experientes quanto tradutores em início de carreira que serão expostos a um aprendizado formal. 
Caso dois ou mais projetos conquistem o mesmo número de pontos na avaliação dos membros da comissão, a prioridade será concedida ao projeto que apresentar a melhor pontuação no critério (i), seguido dos critérios (ii), (iii) e (iv), nessa ordem.

A FBN exige certas garantias das editoras contempladas. A primeira diz respeito à tiragem mínima, que, no caso de edições apenas em forma de livro impresso, deve ser de, no mínimo, mil exemplares da obra, em primeira edição, e 500 exemplares no caso de reedição. Essas metas estão longe de serem ambiciosas, uma vez que, de acordo com Lawrence Venuti (2013, p. 159), no mercado anglófono, os editores definem como objetivo vender em torno de 5 mil exemplares de uma obra traduzida, e o editor Christopher MacLehose observou certa vez que "a maioria até das melhores obras traduzidas vende entre 1,5 mil e 6 mil cópias"10 (MacLehose, 2004-05, p. 113 apud Venuti, 2013, p. 159). Além disso, a FBN não fecha as portas totalmente a tiragens inferiores a mil exemplares em primeira edição, mas essas situações são examinadas caso a caso pela comissão de avaliação. A fim de atestar que a exigência de tiragem mínima foi cumprida, a editora deve fornecer à instituição comprovante de impressão do número de exemplares definido na proposta apresentada. Além disso, a instituição também exige da editora apoiada um recibo de pagamento de serviços prestados assinado pelo tradutor contratado, confirmando a utilização do apoio recebido para o fim ao qual ele se destina. Ainda como garantia, a editora deve informar, durante o período contratual, dados do cronograma de tradução, das etapas da produção e da previsão de lançamento, de modo que a FBN possa acompanhar o desenvolvimento do projeto editorial da obra.

Cabe também destacar que todos os projetos inscritos no programa, selecionados ou não, passam a fazer parte de um cadastro da FBN que vem a constituir um fundo documental a ser utilizado para fins de pesquisa e mapeamento da produção cultural brasileira.

\footnotetext{
10 "the majority of even the finest books that are translated find their way to sales between 1,500 and 6,000 "
} 
A editora deve cumprir todos os prazos e condições previstos no edital do programa e no termo de compromisso firmado com a instituição, caso contrário estará sujeita às seguintes sanções:

(i) Se a editora descumprir o prazo para entrega da obra depois de esgotadas todas as possibilidades de readequação do cronograma ou se desistir do projeto após o pagamento da primeira parcela, ela deverá devolver o valor concedido com acréscimo de juros e correção monetária, além de ficar impossibilitada de apresentar projetos ao programa por um prazo de até três anos, de acordo com a avaliação da Coordenadoria-Geral do Centro de Cooperação e Difusão;

(ii) Se a editora não honrar o pagamento dos serviços de tradução contratados para o projeto, ela será excluída em definitivo de novos projetos financiados pela FBN.

\subsection{3.}

\section{Uma análise dos resultados do programa de bolsas}

Em uma análise inicial dos dados do programa de bolsas originários do cruzamento do número de bolsas concedidas por país solicitante no período de 1991 a 2018, descobrimos o percentual de bolsas conferidas aos dez principais países requerentes, conforme mostrado no Gráfico 4. A França e a Alemanha - países cujas línguas detêm entre $10 \%$ e $12 \%$ do mercado mundial de traduções e são consideradas centrais - são responsáveis pela solicitação de um grande número de bolsas (125 e 103 bolsas, respectivamente), ao lado de Espanha e Itália (122 e 101 bolsas, respectivamente) - países que assumem uma posição semiperiférica na arena literária mundial, com uma participação que varia entre $1 \%$ e $3 \%$ do mercado internacional (Heilbron; Sapiro, 2007, p. 96). De acordo com o Index Translationum, o site da Unesco dedicado à tradução, a Alemanha, a Espanha e a França, nessa ordem, são os países que mais traduzem textos produzidos por outras culturas e que, portanto, confirmam sua tradição ao aparecerem em destaque entre os países que mais solicitam bolsas de tradução. Na sexta e na oitava posições encontramos, respectivamente, os 
Estados Unidos e o Reino Unido, países nos quais se fala o inglês, língua de partida de mais da metade de todas as traduções no mundo, o que a torna hipercentral. No entanto, apesar da posição de destaque entre as línguas de partida no mundo, o inglês assume uma posição bem mais discreta como língua de chegada. Ainda de acordo com o Index Translationum, os EUA são apenas o $15^{\circ}$ país em uma lista dos que mais traduzem, enquanto o Reino Unido aparece na $19^{\circ}$ posição. Com base nesses dados, fica comprovado que os países de língua inglesa são muito mais traduzidos do que tradutores.

A nossa vizinha Argentina (77 bolsas) assume a quinta posição entre os países que mais requisitaram bolsas. Embora a cultura argentina seja periférica, o espanhol é a quarta língua mais falada no mundo, com a vantagem de ter uma comunidade de falantes muito mais dispersa ao redor do mundo do que a segunda (mandarim) e a terceira (hindi) línguas, concentradas em regiões específicas do globo.

Gráfico 4: Número de bolsas oferecidas pela FBN aos principais solicitantes

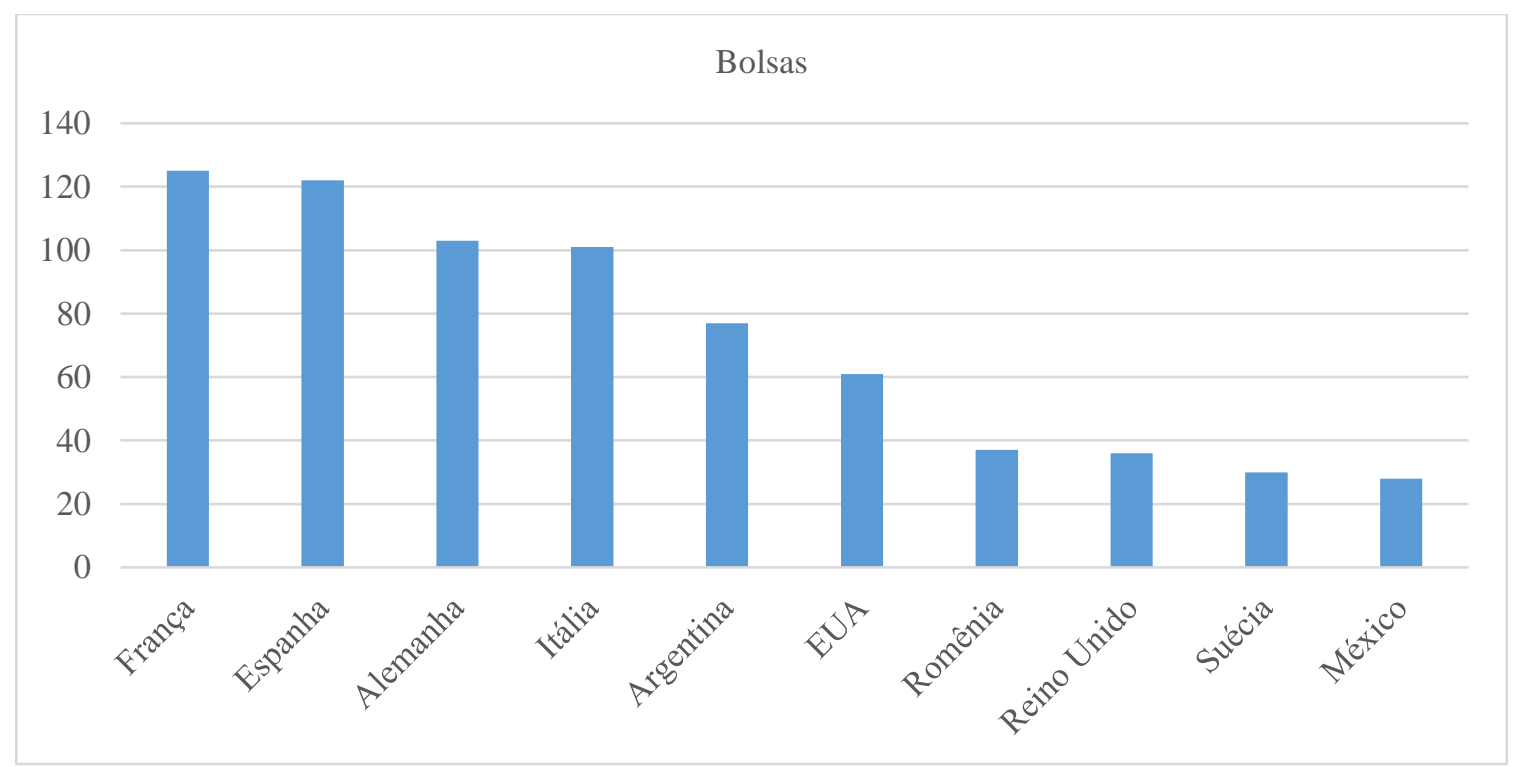

Fonte: Elaborado pela autora da dissertação com base em dados disponibilizados pela FBN (2021)

Essas são as principais estratégias do projeto de internacionalização da literatura brasileira colocadas em prática pela FBN nas últimas três décadas. Além das iniciativas abordadas neste capítulo, a instituição também oferece o Programa de Residência de Tradutores Estrangeiros no Brasil, do qual tratarei no capítulo 4, 
dedicado especificamente ao tradutor de língua portuguesa e aos projetos voltados para ele. 
3.

\section{Os reflexos da patronagem da FBN sobre a circulação dos autores brasileiros no exterior}

Este capítulo tem por objetivo analisar os efeitos - observados até o momento - do projeto da FBN de internacionalização da literatura brasileira sobre a circulação dos nossos autores no exterior, no intuito de (i) compreender, por meio de uma análise do quadro de editoras, autores e obras contempladas com as bolsas de tradução, como as iniciativas da instituição influem na exportação dos textos de nossos escritores para os diversos centros literários internacionais; (ii) examinar a circulação em dois dos principais centros literários mundiais, França e Estados Unidos, das obras literárias dos autores mais beneficiados com as bolsas de tradução a fim de investigar como se desenvolveram alguns dos casos de maior êxito de penetração da literatura produzida no Brasil nos principais centros literários mundiais; e (iii) investigar a inserção dos novos autores da nossa literatura nos cânones que vigoram nos diferentes sistemas de literatura traduzida por meio da participação em antologias financiadas por bolsas de tradução da FBN.

\section{1.}

\section{Distribuição das bolsas de tradução por autor e obra}

Um primeiro recorte no quadro de distribuição de bolsas da FBN por autor revela os escritores cujas obras mais contaram com o incentivo da instituição, como mostrado no quadro 9. As obras dos autores exibidos nesse quadro foram agraciadas com um total de, no mínimo, nove bolsas de tradução, o que os torna os campeões de incentivos governamentais. Vale lembrar, no entanto, que há um número bem maior de escritores cujas obras mereceram de uma a oito bolsas, em um total de 365 autores cujas obras foram contempladas com bolsas da instituição de 1991 até 2018, o que atesta a diversidade de beneficiados pela iniciativa. 
Quadro 9: Relação de autores mais contemplados com bolsas da FBN, número de bolsas e países em que foram publicados.

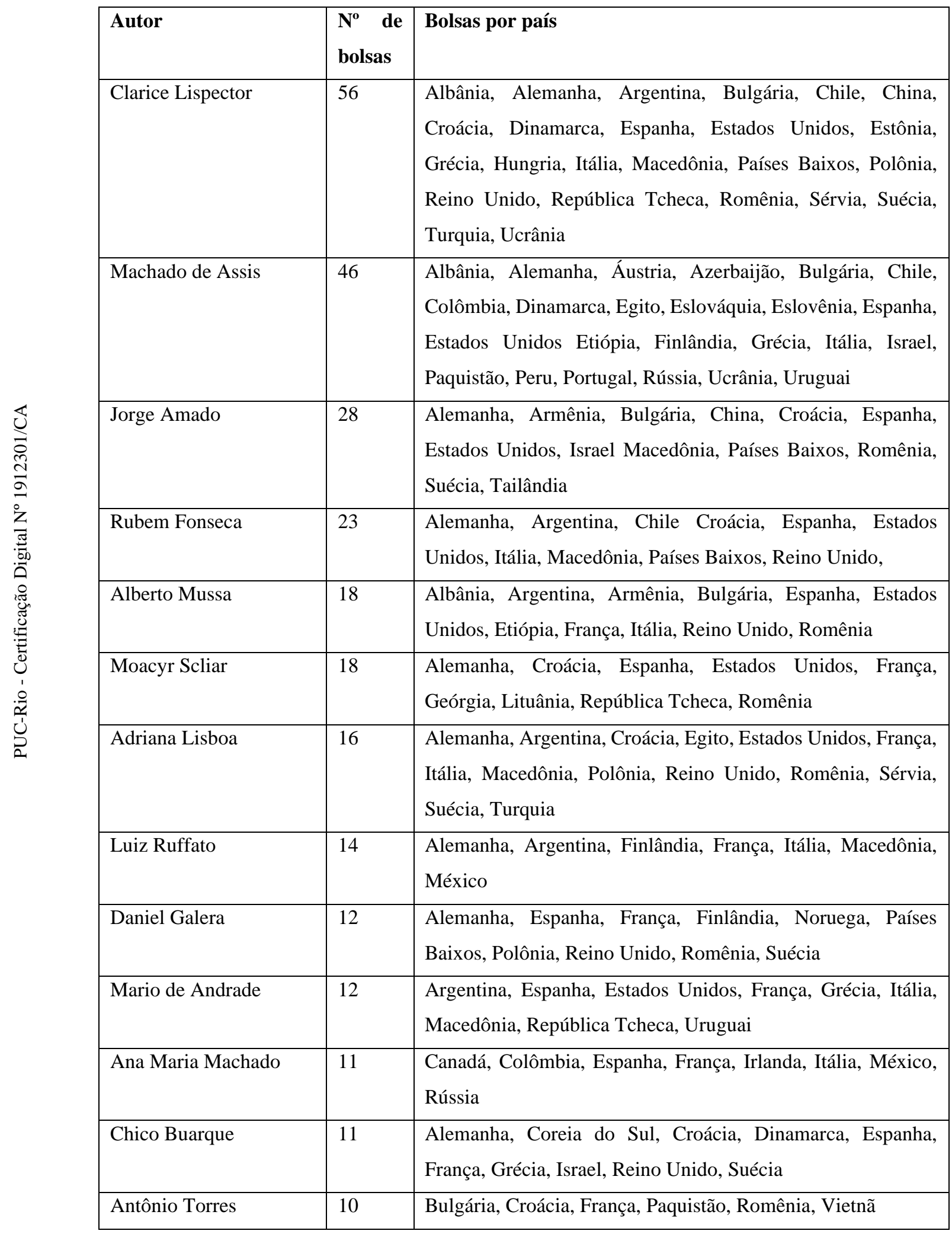




\begin{tabular}{|c|c|c|}
\hline Guimarães Rosa & 10 & $\begin{array}{l}\text { Alemanha, Dinamarca, França, Israel, Noruega, Países Baixos, } \\
\text { Suécia }\end{array}$ \\
\hline Lima Barreto & 10 & $\begin{array}{l}\text { Bulgária, Espanha, França, Itália, México, República Tcheca, } \\
\text { Rússia, Suíça }\end{array}$ \\
\hline Michel Laub & 10 & $\begin{array}{l}\text { Alemanha, Espanha, França, Israel, Itália, Noruega, Países } \\
\text { Baixos, Reino Unido, Suécia }\end{array}$ \\
\hline Andréa del Fuego & 9 & Alemanha, Argentina, França, Israel, Itália, Romênia, Suécia \\
\hline Bernardo Kucinski & 9 & Alemanha, Espanha, Japão, Israel, Itália, Polônia, Reino Unido \\
\hline Ferreira Gullar & 9 & Argentina, Equador, Espanha, Itália, Suécia \\
\hline João Almino & 9 & $\begin{array}{l}\text { Argentina, Espanha, Estados Unidos, França, Itália, } \\
\text { Macedônia, Países Baixos, Sérvia }\end{array}$ \\
\hline $\begin{array}{l}\text { Luis } \\
\text { Veríssimo }\end{array}$ & 9 & $\begin{array}{l}\text { França, Itália, Países Baixos, Reino Unido, Romênia, Sérvia, } \\
\text { Tailândia }\end{array}$ \\
\hline Patrícia Melo & 9 & $\begin{array}{l}\text { Alemanha, Dinamarca, Egito, Espanha, França, México, Reino } \\
\text { Unido, Romênia }\end{array}$ \\
\hline
\end{tabular}

Fonte: Elaborado pela autora da dissertação com base em dados disponibilizados pela FBN (2021)

O quadro 9 se presta a uma reflexão sobre os polos literários atendidos pelo projeto da FBN. Heilbron e Sapiro (2009, p. 19) identificam dois polos literários distintos: o comercial, representado por obras de grande vendagem, e o estético, caracterizado por obras da "alta literatura". Ao contrário da literatura comercial, a literatura de elite não costuma render grandes lucros financeiros a editores e autores. Seu valor é medido pela importância cultural e intelectual atribuída às obras pertencentes a esse campo, que têm potencial para se tornar grandes clássicos. A julgar pelas obras e autores contemplados com bolsas, o programa da FBN atua principalmente no polo estético, procurando financiar obras de pouco apelo comercial, talvez porque a publicação de autores com boa vendagem dispense incentivos. No entanto, a instituição não deixa de contemplar o polo comercial, representado por obras de autores de romances policiais, como Patrícia Melo, agraciada nove vezes, e Luiz Alfredo Garcia-Roza, traduzido duas vezes com o incentivo da instituição, ou até mesmo o sucesso de vendas Paulo Coelho, cuja obra recebeu o apoio da instituição para publicação no exterior apenas em quatro ocasiões: duas vezes na China e outras duas vezes na Armênia, ou seja, bem longe dos grandes centros culturais mundiais, 
atendendo a um dos principais critérios para a concessão das bolsas que é a busca da diversidade de autores, épocas, línguas e regiões atendidas.

Os resultados obtidos no quadro também não diferem daqueles apontados pelo "Mapeamento da Literatura Brasileira no Exterior", iniciativa desenvolvida pelo projeto Itaú Cultural, em 2009, que procurou saber de profissionais relacionados à literatura brasileira, entre eles tradutores, pesquisadores e professores, quais os autores brasileiros que já haviam lido ou traduzido. Os doze autores mais citados, por ordem, foram: Machado de Assis, Clarice Lispector, Guimarães Rosa, Jorge Amado, Carlos Drummond de Andrade, Graciliano Ramos, Chico Buarque, Mario de Andrade, Rubem Fonseca, Milton Hatoum, Oswald de Andrade e João Cabral de Melo Neto, todos eles nomes consagrados de nossa literatura, dentro e fora do país. Sem surpresas, a maioria desses autores aparece no quadro 9 entre os mais procurados pelas editoras, com exceção de Graciliano Ramos, agraciado com quatro bolsas, Carlos Drummond de Andrade, contemplado com cinco, e Milton Hatoum, beneficiado com sete bolsas. Apenas Oswald de Andrade e João Cabral de Melo Neto receberam menos atenção das editoras estrangeiras, tendo as respectivas obras recebido o incentivo da FBN apenas em uma ocasião.

Cabe destacar a diversidade de gêneros e épocas observada entre os agraciados: encontramos desde clássicos do século XIX, como Machado de Assis e Lima Barreto, até modernistas, como Mario de Andrade e Oswald de Andrade; de romancistas, como Autran Dourado ou Moacyr Scliar, a poetas, como Carlos Drummond de Andrade e João Cabral de Melo Neto; de autores contemporâneos consagrados, como Rubem Fonseca e Milton Hatoum, a novos nomes, como Santiago Nazarian e Antônio Xerxenesky, ou mesmo expoentes da chamada literatura marginal, como Paulo Lins e Ferréz, o que parece expressar um desejo de expansão da representatividade da literatura brasileira por parte de editores e leitores estrangeiros. Embora o apoio aos autores seja bastante diversificado, a FBN ainda precisa encontrar meios de incentivar a tradução dos pensadores brasileiros, como Antonio Candido ou Paulo Freire, as escritoras, tradicionalmente menos lembradas do que os escritores, e os representantes de outras minorias, todos com presença restrita no quadro geral de autores. 
O quadro 10 permite tecer comentários sobre as obras mais procuradas pelos editores estrangeiros. Destacam-se obras de autores com boa penetração nos mercados culturais do exterior, como Machado de Assis e Clarice Lispector, mas também obras de autores contemporâneos, como Daniel Galera e Michel Laub. Essa relação de autores que já conquistaram seu espaço em sistemas de literatura traduzida hegemônicos e outros que apenas despontam no exterior se explica pelo fato de que os autores contemporâneos foram beneficiados pela homenagem ao Brasil na Feira do Livro de Frankfurt em 2013, que suscitou o interesse dos leitores e do mercado editorial como um todo pelos escritores brasileiros, traduzindo-se em um grande número de solicitações de bolsas para tradução de obras de novos autores da literatura brasileira. Isso não significa que eles tenham alcançado o status de clássicos da literatura mundial, mas apenas que representem novas apostas do mercado.

Quadro 10: Obras mais contempladas com bolsas da FBN por autor.

\begin{tabular}{|c|c|c|}
\hline Autor & Título & $\mathrm{N}^{0}$ de bolsas \\
\hline $\begin{array}{l}\text { Antologias (vários } \\
\text { autores) }\end{array}$ & - & 37 \\
\hline Machado de Assis & Dom Casmurro & 10 \\
\hline Clarice Lispector & A hora da estrela & 10 \\
\hline Machado de Assis & Memórias póstumas de Brás Cubas & 9 \\
\hline Daniel Galera & Barba ensopada de sangue & 9 \\
\hline Michel Laub & Diário da queda & 9 \\
\hline Bernardo Kucinski & $\mathrm{K}$ & 8 \\
\hline Alberto Mussa & O senhor do lado esquerdo & 8 \\
\hline Clarice Lispector & A paixão segundo G.H. & 7 \\
\hline Moacyr Scliar & Os leopardos de Kafka & 7 \\
\hline Raduan Nassar & Lavoura arcaica & 7 \\
\hline Jorge Amado & Gabriela, cravo e canela & 6 \\
\hline Adriana Lisboa & Sinfonia em branco & 6 \\
\hline Chico Buarque & Budapeste & 6 \\
\hline Andréa del Fuego & Os Malaquias & 6 \\
\hline João Paulo Cuenca & $\begin{array}{l}\text { O único final feliz para uma história de amor é um } \\
\text { acidente }\end{array}$ & 6 \\
\hline
\end{tabular}




\begin{tabular}{|l|l|l|}
\hline Paulo Lins & Cidade de Deus & 6 \\
\hline Diogo Mainardi & A queda & 6 \\
\hline Clarice Lispector & Um sopro de vida & 5 \\
\hline Alberto Mussa & O enigma de Qaf & 5 \\
\hline Adriana Lisboa & Azul-corvo & 5 \\
\hline Mário de Andrade & Amar, verbo intransitivo & 5 \\
\hline Chico Buarque & Leite derramado & 5 \\
\hline Antônio Torres & Essa terra & 5 \\
\hline Luis Fernando Veríssimo & Os espiões & 5 \\
\hline Patrícia Melo & Ladrão de cadáveres & 5 \\
\hline Tatiana Salem Levy & A chave de casa & 5 \\
\hline
\end{tabular}

Fonte: Elaborado pela autora da dissertação com base em dados disponibilizados pela FBN (2021)

\section{2.}

\section{A circulação de Clarice Lispector, Machado de Assis e Jorge Amado no exterior}

Vale refletir sobre o caso dos autores mais procurados pelas editoras, entre os quais se destacam Clarice Lispector, Machado de Assis e Jorge Amado, que, ao lado de Paulo Coelho, José Mauro de Vasconcelos e Leonardo Boff, compõem a lista dos 6 brasileiros entre os 10 autores mais traduzidos da língua portuguesa, de acordo com o site Index Translationum. A obra de Clarice Lispector foi agraciada com 56 bolsas, enquanto os textos de Machado de Assis foram traduzidos 46 vezes com o auxílio das bolsas da instituição, e a obra de Jorge Amado contou com o incentivo de um total de 28 bolsas. Como já mencionado, a obra de Paulo Coelho recebeu apenas quatro vezes o incentivo da instituição, enquanto o trabalho de José Mauro de Vasconcelos foi agraciado cinco vezes com bolsas e os textos de Leonardo Boff nunca contaram com bolsas da instituição. A análise dos três autores mais premiados com as bolsas da FBN se concentrará na circulação de suas obras na França e nos EUA. A França foi escolhida por ser Paris a capital da denominada República Mundial das Letras, na qual, segundo Pascale Casanova, todos os autores precisam se consagrar a fim de conquistar fama mundial. Os Estados Unidos foram selecionados por dois motivos. Primeiro, o país é o maior mercado editorial do mundo, embora seja bastante fechado para obras escritas 
em qualquer língua que não a inglesa, como nos informa Flora Thomson-Deveaux (2020), tradutora de Machado de Assis, que cita 3\% como o percentual de obras traduzidas no mercado estadunidense. No entanto, esse percentual, embora pequeno, se traduz em um grande número de obras em virtude do tamanho do mercado norteamericano. Segundo, o inglês é considerado atualmente a mais importante língua franca global, aquela para a qual todos os autores em busca de projeção internacional desejam ser traduzidos, uma vez que, por se tratar de uma língua hipercentral, uma tradução para o inglês pode suscitar traduções diretas ou até mesmo indiretas para várias outras línguas, além de atingir um grande universo de leitores que têm o inglês como segunda língua.

\subsection{1.}

\section{Machado de Assis na França}

Embora as editoras francesas nunca tenham buscado o apoio da FBN para publicar Machado de Assis, não podemos nos esquecer de que o autor viveu e escreveu no século XIX, época em que um escritor só conquistava a consagração mundial quando celebrado na França. Portanto, não é possível falar da circulação de Machado de Assis no exterior sem analisar sua recepção na França.

O leitor francês demorou quase um século para se interessar por Machado de Assis, situação para a qual contribuíram o status da língua portuguesa e a postura do editor de Machado, além da falta de tradutores e críticos literários que dominassem o português, bem como de editores que conhecessem a obra do autor. Machado de Assis buscava a fama mundial, portanto, queria ver suas obras traduzidas. No entanto, o autor vendeu a seu editor, Hippolyte Garnier, os direitos autorais de todas as suas obras, muitas vezes por preço insignificante (Guimarães, 2004, p. 120 apud Penjon, 2019, p. 190), sendo obrigado, posteriormente, a solicitar a ele autorização para publicar um de seus textos em alemão, com tradução de Alexandrina Highland, o que lhe foi negado (Rouanet, 2008, p. 378 apud Penjon, 2019, p. 189-190). A situação dos direitos autorais do autor impediu, durante muito tempo, a tradução de suas obras e, consequentemente, a consagração no exterior. 
Foi só a partir de 1910 que Hippolyte Garnier e seus sucessores promoveram as obras de Machado de Assis em francês. Nessa época, vigorava a ideia de latinidade, isto é, da busca de aproximação entre a França e as nações latinas do velho e do novo mundos, de modo a contrabalançar as influências culturais e econômicas de outras nações que vinham se destacando no cenário internacional, como Inglaterra, Alemanha, Itália e Estados Unidos. Foi nesse cenário que ocorreram as duas primeiras traduções de obras inteiras de Machado de Assis para o francês: Várias histórias, transposta em 1910 com o título Quelques contes, e, no ano seguinte, Memórias póstumas de Brás Cubas. O tradutor dessas obras foi o belga, radicado no Rio de Janeiro, Adrien Delpech, professor de francês, sociologia e literatura brasileira e latina do Colégio Pedro II e da Escola Normal, entre outras instituições (Sales; Torres, 2018). Sua tradução é objeto de várias críticas em virtude de decisões questionáveis tomadas por ele, como, por exemplo, a de eliminar o capítulo CXXX da obra, além de omitir a dedicatória ao verme e o prólogo assinado pelo autor, presente desde a quarta edição de 1899. Em uma crítica contundente dirigida ao trabalho de Delpech, Raimundo Magalhães Júnior se expressa da seguinte forma: "Foi assim que, três anos após a morte de Machado de Assis, os irmãos Garnier lhe ‘honraram' a memória, com a divulgação, em mau francês, do maior dos seus romances..." (Correio da Manhã, 26 out. 1957, p. 9 apud Pejon, 2019, p. 193). Além dessas obras, alguns contos de Machado de Assis também foram traduzidos para o francês e publicados em forma de folhetim no semanário Courrier du Brésil no período de dezembro de 1910 a novembro de 1911, mas sem grande repercussão. A indiferença do público a Machado de Assis talvez se deva ao momento em que sua obra foi apresentada aos franceses. Na época, embora o autor recebesse muitos elogios de Anatole France e fosse comparado a Prosper Mérimée, muito se censurava em suas obras a ausência do pitoresco, de descrições de paisagens (Penjon, 2019, p. 194), muito apreciadas pelos franceses e identificadas com nosso país, uma vez que, a partir de 1896, passaram a ser oferecidas aos leitores obras de autores como José de Alencar e Visconde de Taunay, que valorizavam a natureza tropical e um certo caráter aventureiro relacionado aos trópicos.

Em 1936, o Instituto Internacional de Cooperação Intelectual lançou Dom Casmurro, em tradução do crítico literário e escritor Francis de Miomandre. A obra foi 
apresentada em diversas revistas literárias e, pela primeira vez na França, um crítico identificou o humor de Machado de Assis com o de Laurence Sterne. No entanto, mesmo entre seus admiradores, muitos ainda se ressentiam da ausência de descrições de paisagens pitorescas na obra do autor (Penjon, 2019, p. 195). Só quando Roger Bastide, professor da recém-criada Universidade de São Paulo (USP), atacou a questão do tratamento dispensado à natureza na obra do autor, os críticos passaram a ver as descrições paisagísticas na obra do autor com outros olhos. Para Bastide, as curtas descrições de paisagens se deviam ao estilo de prosa eleito por Machado de Assis. Diz o sociólogo:

O gênero cultivado por Machado de Assis e seus processos técnicos, eis sem dúvida a principal razão que lhe impedia consagrar na sua obra longos trechos à descrição da natureza. É, com efeito, a lei de todos os gêneros curtos, como o conto, a novela, resumir o drama ao essencial, concentrar o interesse em vez de deixá-lo dispersar-se em pontos secundários, e é evidente que a paisagem só poderia desviar a atenção. (Bastide, 1940 [2005], p. 418)

Portanto, a eliminação de longas descrições paisagísticas foi uma imposição mesma das normas estéticas do gênero praticado pelo autor e dos métodos por ele empregados. Além de abordar a questão das paisagens em Machado de Assis, Bastide elogiou bastante a tradução de Miomandre.

Oito anos depois, foi a vez de Memórias póstumas de Brás Cubas receber uma nova tradução, em 1944, de René Chadebec de Lavalade, último chefe da missão militar que a França mantinha no Brasil desde 1919. Essa tradução não mereceu muita atenção do público ou da crítica por ter sido publicada em período pouco propício, isto é, em meio à Segunda Guerra Mundial.

Só na década de 1950 a América Latina como um todo viria a conquistar visibilidade na França. Nessa década, em que o interesse pelo Brasil cresceu, vários autores brasileiros, como Jorge Amado, Euclides da Cunha, José Lins do Rego, Érico Veríssimo entre outros, foram traduzidos para o francês. Em 1955, a editora Nagel, com o auxílio da Unesco, lançou Quincas Borba, em tradução de Alain de Acevedo com prefácio de Roger Bastide. O leitor francês, no entanto, continuava a apreciar o exotismo, as imagens tropicais, o carnaval e o samba. Com o tempo Machado de Assis conseguiu conquistar o círculo acadêmico francês, mas continuou desconhecido do 
grande público, tanto que uma pesquisa de opinião, realizada entre 1978 e 1980, revelou que só $1 \%$ do público francês conhecia ou ouvira falar de Machado de Assis, contra 8\% para Jorge Amado e 3\% para João Guimarães Rosa (Fresco, 1981 apud Penjon, 2019, p. 198).

Na década de 1980, Machado de Assis passou a contar com mais uma grande admiradora de sua obra não apenas no círculo acadêmico, mas no meio editorial. AnneMarie Métaillié formou-se em Letras na Universidade Sorbonne, onde estudou com Antonio Candido e George Boisvert, que a apresentou a Machado de Assis e sua obra. Em 1979, Métaillié fundou uma editora de mesmo nome que começou publicando obras de Ciências Humanas, mas, com o tempo, começou a se dedicar à publicação também de textos literários. A primeira obra escolhida para publicação foi Dom Casmurro de Machado de Assis, texto que Métaillié estudou com o professor Boisvert, em 1963, mas que, ao ler em francês, notou que faltava à tradução a ironia do texto em português. Empenhou-se então em transpor para o francês o que lia em português. Foi assim que decidiu lançar uma nova tradução de Dom Casmurro, por Anne-Marie Quint. Essa tradução foi bem acolhida e recebeu críticas positivas da imprensa. Aos poucos, a editora Métaillié publicou Esaú e Jacó e Memorial de Aires, em traduções inéditas, e relançou a tradução de Memórias póstumas de Brás Cubas de Lavalade. Os tradutores escolhidos eram quase todos professores universitários, e os prefácios eram escritos por especialistas. Em 1997, Anne-Marie Métailié desenvolveu a coleção "suite brésilienne", em formato mais moderno e barato, e, para o Salão do Livro de Paris de 2015, criou a "suite machadiana", que conta mais de sete volumes. Enfim, a contribuição da editora para a divulgação da obra de Machado de Assis tem sido considerável. Podemos dizer que, graças ao trabalho e ao empenho de Anne-Marie Métailié, o público de Machado de Assis cresceu e se diversificou, e hoje o autor é considerado um dos maiores escritores brasileiros em circulação no universo literário internacional. Apresento, a seguir, um quadro com as obras de Machado traduzidas para o francês. 
Quadro 11: Obras de Machado de Assis traduzidas para o francês com os respectivos anos de publicação, tradutores, reedições e editoras.

\begin{tabular}{|c|c|c|c|c|}
\hline Obra & $\begin{array}{l}\text { Ano de } \\
\text { Publicação }\end{array}$ & Tradutor & Reedições & Editora \\
\hline Várias histórias & 1910 & Adrien Delpech & - & - \\
\hline $\begin{array}{l}\text { Memórias póstumas de } \\
\text { Brás Cubas }\end{array}$ & 1911 & Adrien Delpech & - & Garnier \\
\hline Dom Casmurro & 1936 & $\begin{array}{ll}\text { Francis } & \mathrm{de} \\
\text { Miomandre } & \end{array}$ & $\begin{array}{l}1956, \\
1989,1997\end{array}$ & $\begin{array}{l}\text { Stock / IICI (1936) } \\
\text { Albin Michel (1956, } \\
\text { 1989), Le Livre de } \\
\text { Poche (1997) }\end{array}$ \\
\hline $\begin{array}{l}\text { Memórias póstumas de } \\
\text { Brás Cubas }\end{array}$ & 1944 & $\begin{array}{l}\text { René Chadebec } \\
\text { de Lavalade }\end{array}$ & 1948,1989 & $\begin{array}{l}\text { Atlântica (1944), Emile- } \\
\text { Paul Frères (1948), } \\
\text { Métaillié (1989) }\end{array}$ \\
\hline Quincas Borba & 1955 & $\begin{array}{ll}\text { Alain } & \text { de } \\
\text { Acevedo } & \end{array}$ & - & Nagel \\
\hline Dom Casmurro & 1983 & $\begin{array}{l}\text { Anne-Marie } \\
\text { Quint }\end{array}$ & 2014 & Métailié \\
\hline$O$ alienista & 1984 & $\begin{array}{l}\text { Maryvonne } \\
\text { Lapouge }\end{array}$ & 2014 & Métailié \\
\hline Esaú e Jacó & 1985 & François Duprat & 2014 & Métailié \\
\hline O relógio de ouro & 1987 & $\begin{array}{l}\text { Maryvonne } \\
\text { Lapouge }\end{array}$ & 2014 & Métailié \\
\hline Quincas Borba & 1990 & Jean-Paul Bruyas & $\begin{array}{l}1995, \\
1997,2014\end{array}$ & Métailié \\
\hline Memorial de Aires & 1995 & Jean-Paul Bruyas & 2014 & Métailié \\
\hline Várias histórias & 2015 & Saulo Neiva & 2017 & Garnier \\
\hline
\end{tabular}

Fonte: Elaborado pela autora da dissertação (2021)

\subsection{2.}

\section{Machado de Assis nos EUA}

Em inglês, as primeiras traduções das obras de Machado de Assis só surgiram na década de 1950, quando foram transpostas pela primeira vez aquelas que viriam a ser as obras mais conhecidas do autor no exterior, ou seja: Memórias Póstumas de Brás 
Cubas (1952), Dom Casmurro (1953) e Quincas Borba (1954). A princípio, essas traduções, republicadas sucessivas vezes até os anos 1990, não tiveram grande repercussão. Machado de Assis só passaria a receber atenções do círculo literário estadunidense a partir da década de 1990, quando inclusive mereceu novas traduções dos romances Memórias Póstumas de Brás Cubas (1997) e Quincas Borba (1998), traduzidos por Gregory Rabassa; Dom Casmurro (1997), vertido por John Gledson; e Esaú e Jacó (2000), em tradução de Elizabeth Lowe. Vinte anos depois, em 2020, testemunhamos o lançamento de duas novas traduções de Memórias póstumas de Brás Cubas. A primeira - da tradutora Flora Thomson-Deveaux, lançada pelo selo Penguin Classics, pertencente ao Penguin Random House, o maior grupo editorial do mundo alcançou grande êxito e esgotou nos sites da Amazon e da livraria Barnes \& Noble em um dia (Vaiano, 2020). A segunda - realizada por Margaret Jull Costa para a W. W. Norton \& Company, pequena editora que já contava em seu catálogo com duas antologias de contos de Machado de Assis - recebeu menos atenção da mídia. Após tantas traduções e retraduções, Machado de Assis parece ter conquistado um lugar entre os clássicos universais, mas para tanto ele precisou contar com a patronagem de diversos intelectuais que trabalharam para que suas obras se tornassem conhecidas no mundo anglo-saxão.

Quadro 12: Obras de Machado de Assis traduzidas para o inglês com os respectivos anos de publicação, tradutores, reedições e editoras.

\begin{tabular}{|c|c|c|c|c|}
\hline Obra & $\begin{array}{l}\text { Ano de } \\
\text { Publicação }\end{array}$ & Tradutor & Reedições & Editora \\
\hline $\begin{array}{l}\text { Memórias Póstumas de } \\
\text { Brás Cubas }\end{array}$ & 1952 & $\begin{array}{ll}\text { William } & \text { L. } \\
\text { Grossman } & \end{array}$ & $\begin{array}{l}1953,1956, \\
1959,1968, \\
1973,1978, \\
1984,1985, \\
1990,1991\end{array}$ & 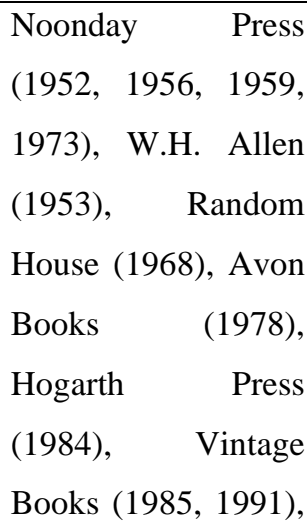 \\
\hline
\end{tabular}




\begin{tabular}{|c|c|c|c|c|}
\hline & & & & $\begin{array}{l}\text { Farrar Straus and } \\
\text { Giroux (1990) }\end{array}$ \\
\hline Dom Casmurro & 1953 & Helen Caldwell & 1993 & $\begin{array}{l}\text { Noonday Press } \\
(1953), \quad \text { Longmans } \\
\text { (1953), Farrar Straus } \\
\text { and Giroux (1953, } \\
\text { 1993), W. H. Allen } \\
\text { (1953), University of } \\
\text { California Press } \\
\text { (1966) }\end{array}$ \\
\hline Quincas Borba & 1954 & Clotilde Wilson & & $\begin{array}{l}\text { Noonday Press } \\
\text { (1954), Farrar Straus } \\
\text { and Giroux (1954), } \\
\text { W. H. Allen (1954) }\end{array}$ \\
\hline $\begin{array}{l}\text { Memórias Póstumas de } \\
\text { Brás Cubas }\end{array}$ & 1955 & E. Percy Ellis & & $\begin{array}{l}\text { Instituto Nacional do } \\
\text { Livro }\end{array}$ \\
\hline$O$ alienista & 1963 & $\begin{array}{l}\text { William } \quad \text { L. } \\
\text { Grossman e Helen } \\
\text { Caldwell }\end{array}$ & 2012,2013 & $\begin{array}{lr}\text { University } & \text { of } \\
\text { California } & \text { Press } \\
(1963), & \text { Melville } \\
\text { House } & \text { (2012), } \\
\text { Hackett (2013) }\end{array}$ \\
\hline Esaú e Jacó & 1965 & Helen Caldwell & 1966,1982 & $\begin{array}{l}\text { University of } \\
\text { California Press } \\
(1965,1966,1982), \\
\text { Peter Owen (1966) }\end{array}$ \\
\hline Dom Casmurro & 1966 & $\begin{array}{ll}\text { Robert } & \text { Scott- } \\
\text { Buccleuch } & \end{array}$ & 1992 & Peter Owen \\
\hline A mão e a luva & 1970 & Albert I. Jr. Babgy & 2014 & $\begin{array}{l}\text { University Press of } \\
\text { Kentucky }\end{array}$ \\
\hline Memorial de Aires & 1972 & Helen Caldwell & 1973 & $\begin{array}{ll}\text { University } & \text { of } \\
\text { California Press }\end{array}$ \\
\hline Iaiá Garcia & 1976 & $\begin{array}{ll}\text { Robert } & \text { Scott- } \\
\text { Buccleuch } & \end{array}$ & & Peter Owen \\
\hline Iaiá Garcia & 1977 & Albert I. Jr. Bagby & 2014 & $\begin{array}{l}\text { University Press of } \\
\text { Kentucky }\end{array}$ \\
\hline Contos & 1977 & $\begin{array}{l}\text { Jack Schmitt \& } \\
\text { Lorie Ishimatsu }\end{array}$ & 1985,1987 & $\begin{array}{l}\text { University of Texas } \\
\text { Press }\end{array}$ \\
\hline
\end{tabular}




\begin{tabular}{|c|c|c|c|c|}
\hline Helena & 1984 & Helen Caldwell & 2012 & $\begin{array}{ll}\text { University } & \text { of } \\
\text { California Press } & \end{array}$ \\
\hline Memorial de Aires & 1990 & $\begin{array}{ll}\text { Robert } & \text { Scott- } \\
\text { Buccleuch } & \end{array}$ & 2005 & Peter Owen \\
\hline Dom Casmurro & 1992 & $\begin{array}{ll}\text { Robert Scott- } \\
\text { Buccleuch }\end{array}$ & & Owen-Dufour \\
\hline $\begin{array}{l}\text { Memórias Póstumas de } \\
\text { Brás Cubas }\end{array}$ & 1997 & Gregory Rabassa & 1998 & $\begin{array}{l}\text { Oxford University } \\
\text { Press }\end{array}$ \\
\hline Dom Casmurro & 1997 & John Gledson & & $\begin{array}{l}\text { Oxford University } \\
\text { Press }\end{array}$ \\
\hline Quincas Borba & 1998 & Gregory Rabassa & & $\begin{array}{l}\text { Oxford University } \\
\text { Press }\end{array}$ \\
\hline Esaú e Jacó & 2000 & Elizabeth Lowe & & Oxford University Pre \\
\hline $\begin{array}{l}\text { Machado de Assis } \\
\text { (contos) }\end{array}$ & 2018 & $\begin{array}{l}\text { Margaret Jull Costa } \\
\text { e Robin Patterson }\end{array}$ & & W. W. Norton \\
\hline $\begin{array}{l}\text { Machado de Assis } \\
\text { (contos) }\end{array}$ & 2019 & $\begin{array}{l}\text { Margaret Jull Costa } \\
\text { e Robin Patterson }\end{array}$ & & W. W. Norton \\
\hline $\begin{array}{l}\text { Memórias Póstumas de } \\
\text { Brás Cubas }\end{array}$ & 2020 & $\begin{array}{l}\text { Flora Thomson- } \\
\text { Deveaux }\end{array}$ & & $\begin{array}{l}\text { Penguin Random } \\
\text { House }\end{array}$ \\
\hline $\begin{array}{l}\text { Memórias Póstumas de } \\
\text { Brás Cubas }\end{array}$ & 2020 & $\begin{array}{l}\text { Margaret Jull Costa } \\
\text { e Robin Patterson }\end{array}$ & & W. W. Norton \\
\hline
\end{tabular}

Fonte: Elaborado pela autora da dissertação (2021)

Machado de Assis encontrou patronos importantes no sistema literário anglófono, dentre os quais Paulo Moreira (2009, p. 96), professor da Universidade Yale, destaca quatro: John Updike, Susan Sontag, Harold Bloom e Michael Wood. Updike, prestigiado romancista contemporâneo norte-americano, é o primeiro a citar Machado de Assis, ainda na década de 1980, em entrevista à imprensa não especializada. O fascínio de Updike pelo Brasil levou-o até mesmo a escrever um romance chamado Brazil, que reconta a história de Tristão e Isolda ambientada no Rio de Janeiro e protagonizada por um rapaz da favela e uma moça da Zona Sul.

Posteriormente, na década de 1990, Susan Sontag dedicou a Machado de Assis um longo artigo (sete páginas, sem ilustrações) na importante revista New Yorker, em que o apresenta como o maior escritor brasileiro de todos os tempos, de acordo com os 
próprios brasileiros, mas um autor desconhecido fora das fronteiras do Brasil. Além de uma apresentação do autor, o texto serve para filiar Machado à tradição literária de Laurence Sterne, seguida por outros grandes nomes da literatura como o italiano Italo Svevo (1861-1928), o irlandês Samuel Beckett (1906-1989) e, mais recentemente, a americana Elizabeth Hardwick (1916-2007) e o britânico V.S. Naipaul (1932), entre outros. O artigo de Sontag divulga ainda o relançamento, pela renomada editora Farrar, Straus \& Giroux, da primeira tradução de Memórias póstumas de Brás Cubas para o inglês, feita por William L. Grossman e publicada, inicialmente, em 1952, cujo texto seria apresentado pela própria Sontag em um prefácio que replicava justamente o artigo da New Yorker com pequenas modificações.

Outro patrono importante da obra de Machado de Assis em língua inglesa é o professor de Yale e crítico literário Harold Bloom. Bloom tornou-se famoso ao escrever, em 1994, O cânone universal, que consiste em uma leitura panorâmica do que o crítico considerava o centro da literatura ocidental. Sua obra gerou muita controvérsia ao entrar em choque com o que preconizavam os estudos culturais e de gênero. Em 2002, Bloom expandiu sua ideia inicial de cânone e publicou Gênio: os 100 autores mais criativos da história da literatura, no qual amplia o quadro de autores já apresentados na obra anterior, incorporando novos nomes que constituiriam os cem "gênios exemplares" da literatura. A expansão do cânone para além dos limites do mundo anglo-saxão, origem de cerca de 50\% dos gênios citados por Bloom, traz, além dos nomes previsíveis, como Dante, Cervantes, Shakespeare e Borges, autores menos conhecidos, que são apresentados ao grande público com a chancela de Bloom. Quatro nomes de língua portuguesa estão entre os cem escolhidos: Camões e Fernando Pessoa, que já apareciam em $O$ cânone universal, e duas novidades: Eça de Queirós e Machado de Assis. Ao tratar da obra de Machado de Assis, Bloom não faz qualquer referência a Sontag ou a outros estudiosos que se debruçaram sobre seus escritos anteriormente, como John Gledson, tradutor de Dom Casmurro e especialista no autor. A obra de Machado é muito elogiada, mas, de novo, seu texto que merece mais destaque é Memórias póstumas de Brás Cubas, e a influência de Sterne é, mais uma vez, apontada. Apesar das críticas feitas a Bloom e seu conceito de cânone ocidental, a contribuição 
do crítico literário para a divulgação da obra de Machado de Assis no mundo anglófono é inegável.

Ainda em 2002, Michael Wood, crítico literário e professor de literatura da Universidade Princeton, resenhou para o The New York Review of Books, jornal quinzenal de resenhas literárias e culturais, que reúne a elite intelectual do mundo anglo-saxão, as traduções então recentes dos romances Memórias Póstumas de Brás Cubas, Quincas Borba, Dom Casmurro e Esaú e Jacó, à luz de dois textos teóricos sobre a obra do autor: Um mestre na periferia do capitalismo, de Roberto Schwarz, e uma coletânea de artigos de vários autores sobre Machado de Assis, mais especificamente sobre o romance Dom Casmurro, organizada por Richard Graham, professor de história da Universidade do Texas em Austin. Ao longo de sua elogiosa resenha, Wood reafirma a posição de Machado de Assis como um dos maiores escritores do mundo e pergunta: "Os romances de Machado têm sido publicados em inglês e em outras línguas há uns 50 anos. Não há quem o leia sem considerá-lo um mestre - mas quem o lê, quem já ouviu falar dele?” (Wood, 2002, s.p.)

Uma vez que os principais romances de Machado de Assis foram traduzidos para o inglês pela última vez no final da década de 1990, com exceção de Memórias póstumas de Brás Cubras, traduzido também em 2020, as editoras norte-americanas buscaram o apoio da FBN apenas em quatro oportunidades, para ampliar a presença do autor no mundo anglófono por meio da tradução de antologias de contos e crônicas. Das quatro bolsas destinadas a editoras estadunidenses, uma foi concedida à Dalkey Archive Press - editora de prosa ficcional, poesia e crítica literária especializada na publicação ou republicação de obras pouco conhecidas, geralmente de vanguarda - e três, à New London Librarium que, em seu site, se define como uma casa editorial dedicada a publicar, em pequenas tiragens, e comercializar ficção, não ficção, poesia, teatro e traduções de qualidade literária, que possam contribuir para o mundo de forma positiva, mas que não gerem os lucros esperados por outros editores. Quando comparamos esse número com o total de 46 bolsas concedidas para tradução de obras do autor em todo o mundo, constatamos que a busca pela patronagem da instituição nos EUA é bastante limitada, talvez porque Machado de Assis já não precise de tanto incentivo para ser publicado em inglês. 
As traduções das obras de Machado de Assis para o francês e o inglês exerceram grande influência mundial e levaram 21 países, entre centros culturais hegemônicos, como a Alemanha, a Espanha e a Itália, e centros periféricos, como Paquistão, Egito e Etiópia, a requisitarem as bolsas da FBN a fim de traduzir principalmente os romances da fase madura do autor, os mesmos já consagrados em traduções para as línguas francesa e inglesa, mas também suas poesias e contos.

\subsection{3.}

\section{Jorge Amado na França}

A primeira obra de Jorge Amado publicada na França foi Jubiabá, no ano de 1938. À época, Amado enfrentava forte repressão política no Brasil, e a publicação de suas obras em território nacional estava proibida. A apresentação de Jorge Amado à França ocorreu graças à patronagem de dois professores e tradutores: Michel Berveiller e Pierre Hourcade. Em uma viagem ao Brasil, os tradutores tiveram contato com o romance e sugeriram a tradução à editora Gallimard. Ao receberem a aprovação da casa editorial, Berveiller e Hourcade enviaram carta ao autor, propondo um contrato de tradução.

Um ano após sua publicação, a obra mereceu uma matéria elogiosa do escritor e filósofo Albert Camus, publicada no jornal Alger Républicain. Essa crítica foi um início promissor na França para um autor que, em casa, apesar de prestigiado pelo público, não gozou do reconhecimento de parte da crítica literária acadêmica brasileira por bastante tempo, sobretudo da crítica do Sul e do Sudeste do país, como comprovamos em matéria assinada pelo crítico literário paulista Wilson Martins, publicada em 1947 no periódico Arte Literatura:

O caso de um Jorge Amado, oferecendo-nos continuamente o espetáculo de sua decadência literária, seja por se ter em definitivo deixado empolgar pela política partidária, seja (o que reputo mais provável) por ter rapidamente esgotado as suas reservas de originalidade criadora, me parece ser dos mais expressivos. (Martins, 1947, p. 1 apud Santos, 2018, p. 33) 
É possível que essas críticas negativas fossem motivadas por um certo ressentimento dos modernistas paulistas para com os escritores "regionalistas", como Rachel de Queiroz, Graciliano Ramos, José Lins do Rego, Érico Veríssimo e o próprio Amado, nomes que compunham um novo panorama literário com características realistas e inclinação sociológica. Esses autores lançaram um olhar atento a cenários e personagens até então pouco explorados por nossos escritores, e trataram temas como a seca, o migrante nordestino, a decadência das oligarquias rurais, a luta de classes, a miséria urbano-industrial e as discussões étnicas (Santos, 2018, p. 39), entrando para a história da literatura brasileira como representantes do romance social da década de 1930. No prefácio de Menino de engenho traduzido para o francês, o poeta francês Blaise Cendrars cita Amado e seu posicionamento diante dessas críticas:

Os escritores modernistas de São Paulo, que o convidaram, não faziam outra coisa, segundo ele, a não ser imitar de longe o que se escrevia na Europa que declaravam detestar, e "tratavam os escritores do Nordeste como regionalistas e pretenciosos ridículos. [para eles] Fora de São Paulo, não há salvação”. (Cendrars, 2005 apud Rivas, 2005, p.113).

Essas críticas não incomodavam Amado que, de acordo com o pesquisador Eduardo de Assis Duarte (Guedes, 2012), “escolheu ficar longe do cânone literário. Ele queria ser canonizado pelo povo".

A segunda obra de Jorge Amado publicada na França foi Terras do sem fim, em 1946, vertida por Claude Plessis e lançada pela editora Nagel. Essa obra, embora publicada em uma importante coleção, não teve muita repercussão no momento de seu lançamento e só adquiriu certa visibilidade no período de exílio do escritor na França (1948-1950) e na Tchecoslováquia (1950-1952). Até a partida para o exílio, em janeiro de 1948, o escritor já havia publicado treze obras no Brasil, de O país do Carnaval (1931) a Seara Vermelha (1946), mas apenas duas haviam sido traduzidas para o francês e publicadas na França. Jorge Amado partiu para o exílio no início da Guerra Fria, quando a repressão política ao comunismo levou vários intelectuais a buscarem refúgio em Paris. Em comum, esses intelectuais tinham o alinhamento com a União Soviética e a identificação com seu líder, Stálin.

Na França, Louis Aragon, escritor, poeta e ativista da causa comunista, foi responsável por abrir portas de periódicos e editoras francesas a companheiros latino- 
americanos, como Pablo Neruda e o próprio Amado. Durante o período de exílio do escritor na Europa, foram publicadas na França traduções de cinco obras do autor, $O$ cavaleiro da esperança (1949), Mar morto (1949), São Jorge dos Ilhéus (1951), Seara vermelha (1951) e Capitães da areia (1952), e sua produção literária foi divulgada em periódicos, sobretudo comunistas, uma vez que o Partido Comunista Francês (PCF) era um grande patrono da literatura de autores engajados em seus ideais. Entretanto, a obra de Amado transcendeu a influência do PCF e passou a despontar também em periódicos fora do contexto do partido. $\mathrm{O}$ exílio na França, porém, não durou muito e terminou com a perseguição ao escritor que, após ser julgado como agente de Moscou, juntamente com a esposa Zélia Gattai e seus companheiros, foi expulso do território francês em 1950 (Santos, 2018, p. 47).

Em 1955, após as denúncias de Nikita Kruschev contra Stálin, no $20^{\circ}$ Congresso do Partido Comunista da União Soviética, Jorge Amado se desligou do Partido Comunista Brasileiro (PCB) e decidiu dedicar-se apenas à literatura. A obra de Amado pode ser dividida em duas fases: na primeira, que abrange o período em que o autor era ativista do PCB, a ênfase recai sobre os aspectos político-sociais; na segunda, o autor se distancia da militância política, introduz o humor e enfatiza temas como a miscigenação e a cultura negra da Bahia, sem, no entanto, abrir mão do caráter de denúncia social. Esse ponto de inflexão na carreira do autor foi marcado, sobretudo, pela produção da obra Gabriela, cravo e canela, publicada no Brasil em 1958, e na França no ano seguinte. A mudança de trajetória da obra de Jorge Amado foi bem recebida pela cultura letrada francesa e, apesar de não poder contar com o PCF, com o qual cortou relações, o autor continuou a receber cada vez mais atenção do mercado editorial da França.

Há, então, um grande hiato na história da publicação de Jorge Amado na França que se estendeu de 1959 até a década de 1970, quando a Décennales Auteurs publicou Os pastores da noite e a Stock editou, em sequência, seis obras de Amado: A morte e a morte de Quincas Berro d'Água (1971), Dona Flor e seus dois maridos (1972), Tereza Batista (1974), Tenda dos milagres (1976), Os velhos marinheiros (1978) e Tieta do Agreste (1979). Jorge Amado foi bastante beneficiado pelo boom da literatura latino-americana ocorrido no período entre as décadas de 1960 e 1980, fenômeno 
literário que levou à popularização da produção de escritores latino-americanos no mundo, quando obras de escritores como Gabriel Garcia Márquez, Alejo Carpentier e o próprio Amado foram amplamente consumidas pelo público. No entanto, o autor se posicionou contra a existência de uma literatura latino-americana. Segundo Amado:

Não existe uma literatura latino-americana. Existem literaturas nacionais dos mais diversos países de América Latina: uma literatura argentina, peruana, brasileira, venezuelana, cubana, colombiana... ou haitiana. Todas completamente diferentes. Falar de cultura ou literatura latino-americana é usar conceito colonialista. É um impulso colonialista dos espanhóis. E quando, um latino-americano a aceita está adotando uma posição colonial. Eu não sou um escritor latino-americano. Sou um escritor brasileiro... Se junto a países como Cuba há países como Bolívia ou Paraguai, ou países da América Central, se não há nem sequer uma unidade econômica, como pode haver uma unidade cultural ou literária? (Infante, 1987, p. 38 apud Maura, 2014, s.p.)

O sucesso de Amado foi duradouro e não se esgotou após o boom da literatura latino-americana. Nos anos 1980 e 1990, foram publicadas, na França, nada menos do que treze obras do autor, que permanece, até os dias de hoje, no catálogo de três editoras francesas: Le Temps de Cerises, Gallimard e Stock. Por se tratar de uma editora de grande prestígio, o simples fato de uma obra ser aceita pela Gallimard costuma ser visto entre os franceses como um atestado de qualidade. A editora é um importante agente na definição dos cânones da literatura traduzida em solo francês, e Jorge Amado se encontra entre esses cânones, ao ser chancelado pela casa editorial. Já a Stock, pertencente ao sólido grupo de mídia Hachette, reeditou nove obras do autor já neste milênio, uma clara aposta no autor como um clássico da literatura mundial.

Quadro 13: Obras de Jorge Amado traduzidas para o francês com respectivos anos de publicação, tradutores, reedições e editoras.

\begin{tabular}{|l|l|l|l|l|}
\hline Obra & $\begin{array}{l}\text { Ano de } \\
\text { Publicação }\end{array}$ & Tradutor & Reedições & Editora \\
\hline Jubiabá & 1938 & Michel Berveiller & 1981 & Gallimard \\
\hline Terras do sem fim & 1946 & Claude Plessis & - & Nagel \\
\hline Mar morto & 1949 & Noel-A. François & 1982 & $\begin{array}{l}\text { Nagel (1949), } \\
\text { Flammarion (1982) }\end{array}$ \\
\hline
\end{tabular}




\begin{tabular}{|c|c|c|c|c|}
\hline $\begin{array}{l}O \quad \text { cavaleiro da } \\
\text { esperança }\end{array}$ & 1949 & $\begin{array}{ll}\text { Julia e Georges } \\
\text { Soria }\end{array}$ & - & Français Réunis \\
\hline São Jorge dos Ilhéus & 1951 & Violante do Canto & - & Nagel \\
\hline Seara vermelha & 1951 & Violante do Canto & 1981,1998 & $\begin{array}{l}\text { Français } \quad \text { Réunis } \\
(1951), \quad \text { Messidor } \\
\text { (1981), Le Temps de } \\
\text { Cerises (1998) }\end{array}$ \\
\hline Capitães de areia & 1952 & Vanina & 1984 & Gallimard \\
\hline Cacau & 1955 & Jean Orecchioni & 1984,2010 & $\begin{array}{l}\text { Nagel (1955), Stock } \\
(1984,2010)\end{array}$ \\
\hline Gabriela, cravo e canela & 1959 & $\begin{array}{l}\text { Violante do Canto e } \\
\text { Maurice Roche }\end{array}$ & & Seghers \\
\hline Os pastores da noite & 1970 & Conrad Detrez & 1998 & $\begin{array}{l}\text { Décennales Auteurs } \\
\text { (1970), LGF (1998) }\end{array}$ \\
\hline Gabriela, cravo e canela & 1971 & Georges Boisvert & $\begin{array}{l}1983, \\
1997,2012\end{array}$ & Stock \\
\hline $\begin{array}{l}\text { A morte e a morte de } \\
\text { Quincas Berro d'Água }\end{array}$ & 1971 & Georges Boisvert & 2008 & Stock \\
\hline $\begin{array}{l}\text { Dona Flor e seus dois } \\
\text { maridos }\end{array}$ & 1972 & $\begin{array}{l}\text { Georgette Tavares } \\
\text { Bastos }\end{array}$ & 1984,2005 & Stock \\
\hline Tereza Batista & 1974 & Alice Raillard & 1991,2011 & Stock \\
\hline Tenda dos milagres & 1976 & Alice Raillard & 1984,2013 & Stock \\
\hline $\begin{array}{l}\text { Os velhos marinheiros } \\
\text { ou O capitão de longo } \\
\text { curso }\end{array}$ & 1978 & Alice Raillard & 1998,2013 & Stock \\
\hline Tieta do Agreste & 1979 & Alice Raillard & 2007 & Stock \\
\hline $\begin{array}{l}\text { Farda, fardão } e \\
\text { camisola de dormir }\end{array}$ & 1980 & Alice Raillard & 1991,2011 & Stock \\
\hline Suor & 1983 & Alice Raillard & 1991,1993 & $\begin{array}{l}\text { Temps Actuelles } \\
\text { (1983), Gallimard } \\
\text { (1991), Le Temps de } \\
\text { Cerises (1993) }\end{array}$ \\
\hline $\begin{array}{l}O \text { gato malhado e a } \\
\text { andorinha sinhá }\end{array}$ & 1983 & Alice Raillard & & Stock \\
\hline $\begin{array}{l}\text { Os subterrâneos da } \\
\text { liberdade }\end{array}$ & 1984 & Isabel Meyrelles & & Temps Actuels \\
\hline
\end{tabular}




\begin{tabular}{|c|c|c|c|c|}
\hline Terras do sem fim & 1985 & Isabel Meyrelles & $\begin{array}{l}\text { 1991, } \\
1994,1998\end{array}$ & $\begin{array}{l}\text { Messidor (1985), } \\
\text { Gallimard }(1991, \\
\text { 1994), Le Temps de } \\
\text { Cerises (1998) }\end{array}$ \\
\hline Tocaia Grande & 1985 & Jean Orecchioni & & Stock \\
\hline A bola e o goleiro & 1986 & $\begin{array}{l}\text { Caroline Claeys- } \\
\text { Desbans }\end{array}$ & & I.L.M. \\
\hline O menino grapiúna & 1986 & Alice Raillard & & Messidor \\
\hline São Jorge dos Ilhéus & 1986 & Isabel Meyrelles & 1995,1998 & $\begin{array}{l}\text { Messidor (1986), } \\
\text { Gallimard (1995), Le } \\
\text { Temps de Cerises } \\
\text { (1998) }\end{array}$ \\
\hline$A B C$ de Castro Alves & 1988 & Isabel Meyrelles & & Messidor \\
\hline O sumiço da santa & 1989 & Jean Orecchioni & & Stock \\
\hline $\begin{array}{l}\text { Bahia de Todos os } \\
\text { Santos }\end{array}$ & 1989 & Isabel Meyrelles & & Messidor \\
\hline O país do Carnaval & 1990 & Alice Raillard & & Gallimard \\
\hline $\begin{array}{l}\text { A descoberta da } \\
\text { América pelos turcos }\end{array}$ & 1992 & Jean Orecchioni & 2012 & Stock \\
\hline
\end{tabular}

Fonte: Elaborado pela autora da dissertação (2021)

\subsection{4.}

Jorge Amado nos EUA

No período entre a década de 1930 e o final da Segunda Guerra Mundial, o Brasil sofreu grande influência da cultura estadunidense, como consequência de uma política praticada pelo governo norte-americano de aproximação entre os Estados Unidos e os países latino-americanos, visando a impedir a influência europeia na região, manter a estabilidade política no continente e assegurar a liderança norteamericana no hemisfério ocidental. A literatura estrangeira traduzida fez parte dessa política do governo dos EUA, que a tratava como um instrumento de fortalecimento de alianças políticas entre os países da América. O projeto do governo norte-americano começou de forma tímida, com a subvenção da tradução de obras literárias da América Latina por universidades e editoras. Com o tempo, o programa cresceu em importância, 
e a tradução passou a contar com um poderoso patrono oficial: o Departamento de Estado dos EUA.

Esse cenário favorável às letras latino-americanas revelou nomes que viriam a desempenhar papel fundamental na circulação de diversos escritores brasileiros em solo norte-americano, como o editor Alfred A. Knopf e sua esposa Blanche Knopf. A Alfred A. Knopf Publishers publicava tanto literatura estadunidense quanto estrangeira, contando em seu catálogo com nomes de peso como Kafka, Jean Paul Sartre, Thomas Mann, Ezra Pound, Simone de Beauvoir, Albert Camus, Pablo Neruda e Gabriel Garcia Marques. Com o incentivo do Departamento de Estado norte-americano, o fundador e dono da Alfred A. Knopf Publishers buscou autores na América Latina para enriquecer seu projeto de tradução de autores estrangeiros. Knopf publicou traduções de obras de autores como Guimarães Rosa, Jorge Amado, Graciliano Ramos, Cecília Meireles, Gilberto Freyre, entre outros.

No entanto, apesar do incentivo do governo norte-americano, traduzir obras da América Latina e lançá-las nos EUA era uma empreitada arriscada e deficitária, uma vez que o sistema literário estadunidense sempre se mostrou muito refratário a trabalhos de novos autores estrangeiros. Além da resistência à literatura estrangeira, o desconhecimento da cultura latino-americana e a falta de tradutores de português experientes também representavam grandes obstáculos (Tooge, 2009, p. 72).

Nesse contexto, a Alfred A. Knopf Publishers publicou, em 1945, Terras do sem fim, primeira obra de Amado lançada nos Estados Unidos. A obra foi vertida para o inglês por Samuel Putnam, brasilianista que escreveu diversos ensaios, artigos e críticas sobre a produção literária brasileira. A repercussão e a vendagem do romance de Jorge Amado nos Estados Unidos foram inexpressivas e, em virtude do desempenho decepcionante no mercado, a editora decidiu não reeditá-lo (Tooge, 2009, p. 78).

Na década de 1950, o interesse dos Estados Unidos pela América Latina esmoreceu, e a América Latina só veio a despertar novamente o interesse dos norteamericanos após a Revolução Cubana, na década de 1960, quando os Estados Unidos buscaram afastar o fantasma do comunismo do continente americano. Foi nesse cenário que se deu o lançamento, nos Estados Unidos, de Gabriela, cravo e canela, segunda obra de Amado publicada em inglês, em 1962. Esse trabalho representara uma virada 
na obra de Jorge Amado. O autor se afastara do partido comunista em 1957, deixara para trás o realismo social e passara a escrever histórias de amor, muito embora ainda com preocupação social. Quando da publicação de Gabriela, cravo e canela nos Estados Unidos, a obra de Amado já era bastante conhecida na Europa, e esse romance, por exemplo, já fora traduzido para 14 idiomas. Os norte-americanos não ficaram indiferentes a esse grande sucesso internacional, e o romance obteve considerável êxito comercial nos Estados Unidos.

Enquanto no Brasil a situação política se agravava e caminhava para a tomada do poder pelos militares em 1964, nos Estados Unidos os romances de Jorge Amado continuavam a ser publicados. Na década de 1960, Knopf lançou, em sequência, $O s$ velhos marinheiros (1964), A morte e a morte de Quincas Berro d'Água (1965), Os pastores da noite (1967) e, por fim, Dona Flor e seus dois maridos, (1969), que, juntamente com Gabriela, cravo e canela, foi uma das obras mais bem recebidas nos Estados Unidos, o que nos leva a crer que as obras em que Amado moderava o tom político tiveram melhor recepção por parte do público norte-americano. Além disso, pode surpreender o fato de que Gabriela, uma obra rica em referências a rituais de magia, tenha conquistado tão boa aceitação por parte do público protestante norteamericano, mas devemos nos lembrar de que nessa época ocorria uma renovação do boom da literatura latino-americana, e a obra foi enquadrada no contexto literário do realismo mágico (Tooge, 2019, p. 107).

Na época, a principal tradutora da Alfred A. Knopf era Harriet de Onís, que dos quatro romances de Amado publicados na década de 1960, traduziu três: Os velhos marinheiros, Os pastores da noite e Dona Flor e seus dois maridos. Onís, cujo interesse pela literatura hispânica foi despertado quando ainda era aluna de literatura inglesa na Universidade Columbia, é lembrada como uma descobridora de talentos na América Latina, cuja história na Alfred A. Knopf é assim descrita:

Em 1930, a Editora Alfred Knopf ofereceu a Mrs. de Onís a tradução do livro de Martín Luís Guzmán, que tanto a impressionara. Iniciava-se uma parceria que se estenderia por quase quarenta anos. De tradutora, Mrs. de Onís passaria a membro do corpo de conselheiros da editora, como consultora especializada para a América Latina. (Verlangiere, 1993, p. 17 apud Tooge, 2019, p. 88) 
Na década de 1970 foram lançadas mais três obras de Amado em inglês: Tenda dos milagres (1971), Tereza Batista cansada de guerra (1974) e Tieta do Agreste (1979), vertidas por Barbara Shelby, tradutora de outras duas histórias de Jorge Amado: A morte e a morte de Quincas Berro d'Água e $O$ gato malhado e a andorinha sinhá. Shelby trabalhava como assistente de Assuntos Culturais em São Paulo, quando o adido cultural, George Boehrer, mencionou que Knopf procurava um novo tradutor para o português. Barbara Shelby se candidatou e iniciou sua colaboração com a Alfred A. Knopf com a tradução de A morte e a morte de Quincas Berro d'Água. Durante quinze anos, Shelby fez parte da equipe de tradutores da editora e, nessa época, traduziu também obras de Gilberto Freyre, Guimarães Rosa e Antônio Callado.

A partir da década de 1980, Amado ganhou um novo tradutor: Gregory Rabassa. Rabassa, especialista em literatura latino-americana, traduziu autores brasileiros, como Machado de Assis e Clarice Lispector, e latino-americanos, como Gabriel García Márquez, Julio Cortázar e Mario Vargas Llosa. Lecionou na Universidade Columbia por mais de duas décadas antes de aceitar uma cátedra no Queens College, em Nova York. Rabassa conquistou diversos prêmios de tradução, entre eles o National Book Award -juntamente com o Neustadt International Prize for Literature e o Prêmio Pulitzer, um dos mais importantes prêmios literários dos Estados Unidos - e o Prêmio de Tradução PEN, o primeiro dos Estados Unidos dedicado exclusivamente a tradutores.

Atualmente, as obras de Jorge Amado são consideradas clássicos da literatura mundial e são publicadas pela Penguin Random House em traduções para o inglês de Samuel Putnam, Barbara Shelby e Gregory Rabassa.

Quanto ao auxílio das bolsas de tradução da FBN, percebemos que ele é concedido a fim de ampliar a penetração da obra de Amado em centros culturais periféricos, como Israel, China e os países da Europa Oriental, com destaque para a Romênia (seis bolsas) e a Bulgária (cinco bolsas), onde o interesse pela obra de Amado é particularmente grande. Não há nenhuma solicitação de bolsa de tradução para o francês, e muito poucas propostas de tradução para o inglês, contemplado em apenas três ocasiões. 
Quadro 14: Obras de Jorge Amado traduzidas para o inglês com respectivos anos de publicação, tradutores, reedições e editoras.

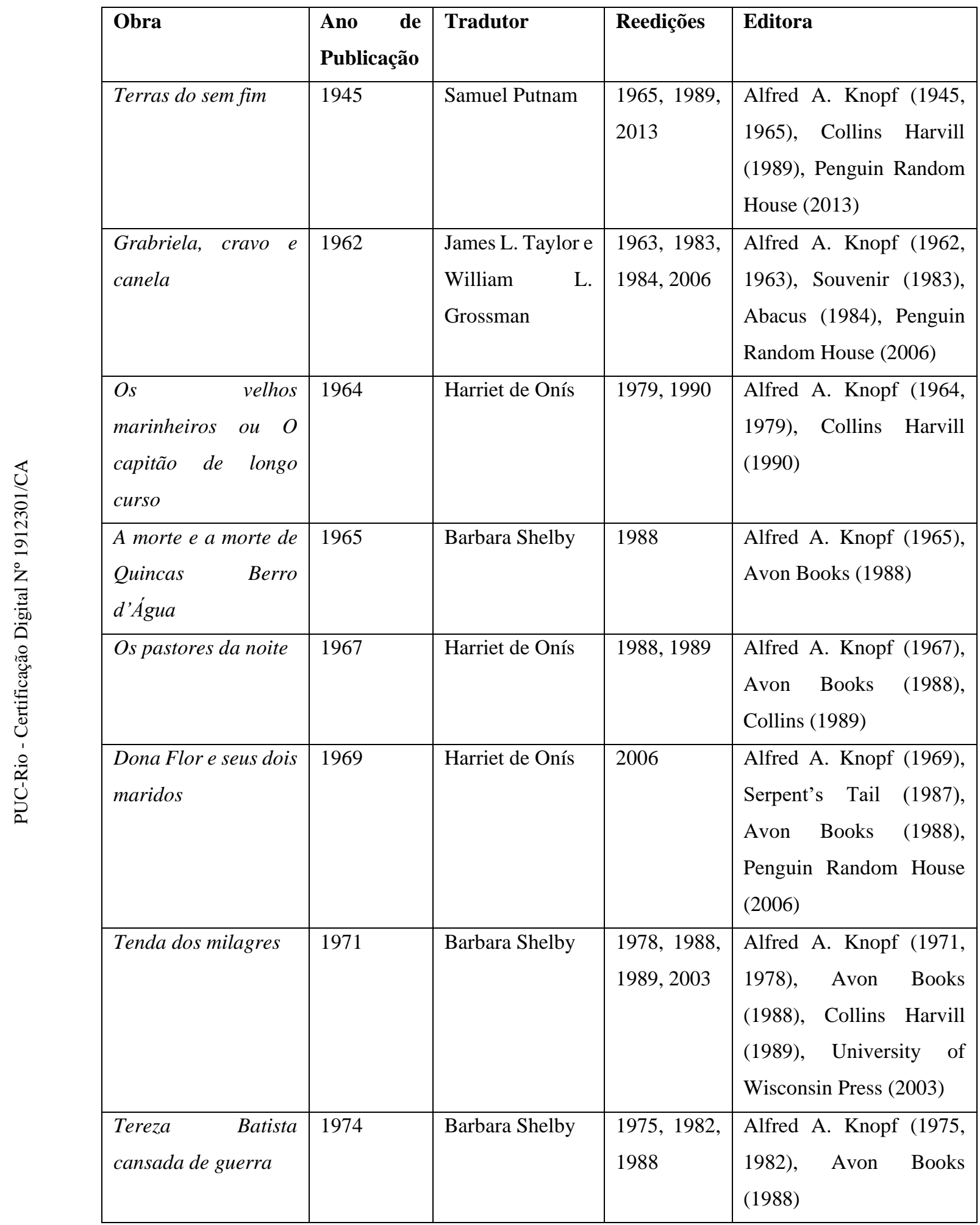




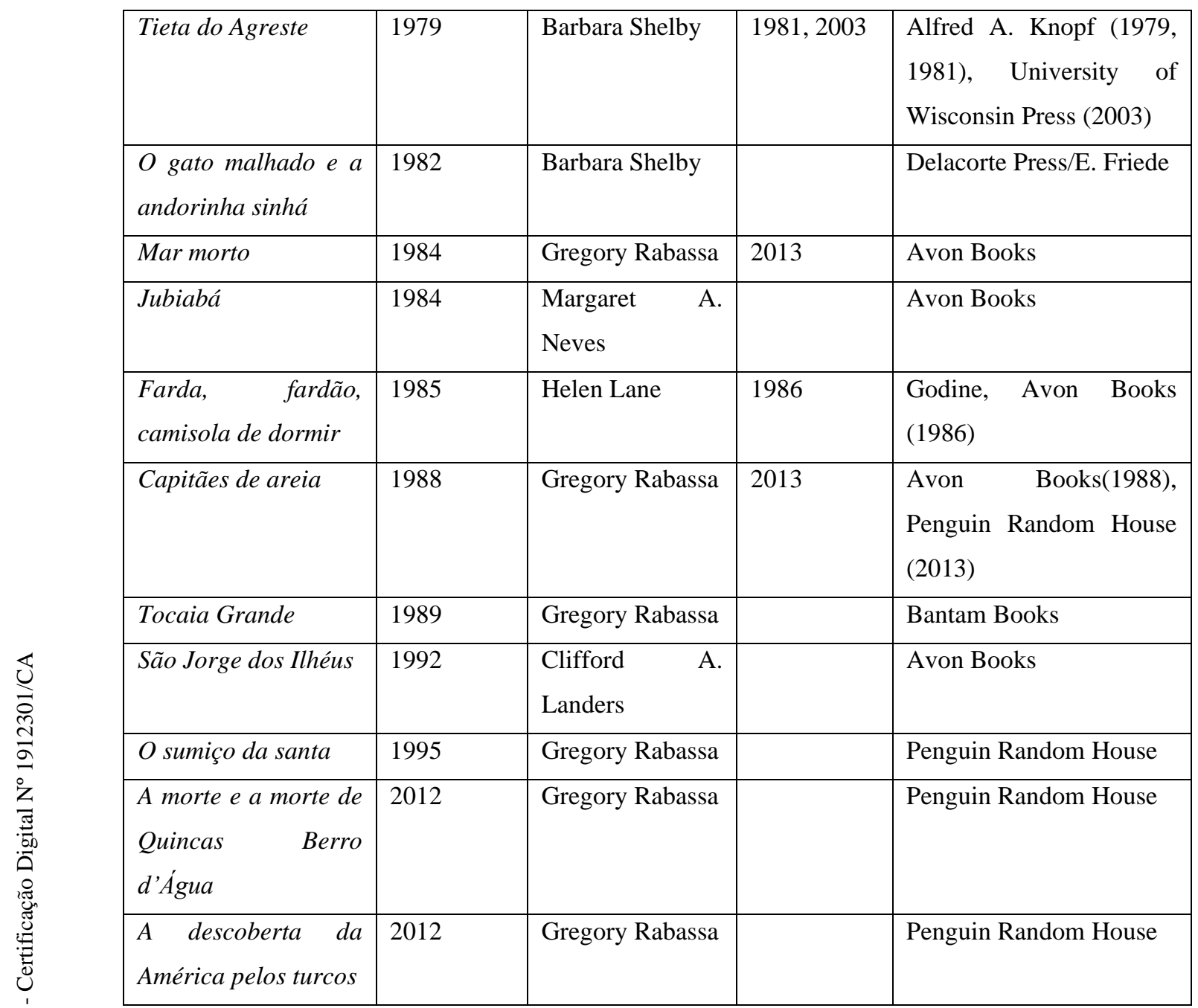

Fonte: Elaborado pela autora da dissertação (2021)

\section{2 .5}

\section{Clarice Lispector na França}

Ivi Fuentealba Villar (2019, p. 198) identifica três momentos distintos no processo de recepção de Clarice Lispector na França. Em um primeiro momento, a autora participou ativamente da inserção de sua obra no país como mediadora e revisora das traduções. Um segundo momento compreendeu o período em que a obra de Lispector foi mediada por Hélène Cixous, organizadora de seminários de estudos literários nos quais analisava a obra da escritora, e autora de artigos e ensaios sobre ela, que repercutiram dentro e fora da França. Um terceiro momento é marcado pelo 
lançamento em francês, no início do século XXI, da biografia da autora brasileira escrita por Benjamin Moser.

O início do primeiro momento é marcado pela publicação, pela editora Plon, em 1954, da obra Perto do coração selvagem, primeira tradução no mundo de uma obra completa de Clarice Lispector. A tradução, de Denise-Teresa Moutonnier, contou com a colaboração da própria autora, que atuou como revisora. Lispector, no entanto, considerou a tradução "escandalosamente" ruim (Pereira, 1995, p. 110) e chegou a solicitar à editora francesa que desistisse de publicá-la. Posteriormente, após verificar que as sugestões feitas por ela durante a revisão haviam sido aceitas, Clarice enviou uma carta à editora desculpando-se e elogiando o trabalho da tradutora (Moser, 2009, p. 209 apud Villar, 2019, p. 199). A obra não obteve boa repercussão e, em 1958, a autora recebeu um comunicado da editora informando que mil exemplares seriam destruídos para liberar espaço no estoque (Hilmmselseher, 2011 apud Villar, 2019, p. 199).

É importante levar em consideração que, após as mobilizações sufragistas do início do século XX, os movimentos feministas começaram a entrar em declínio nos anos de 1930 e, na década de 1950, estavam em pleno refluxo (Dubesset, 2002 apud Villar, 2019, p. 201). Portanto, o momento não era favorável à divulgação de literatura feminina. No entanto, nessa década começavam a se desenvolver o pensamento e os movimentos que se tornariam visíveis em meados dos anos 1960. Foi pouco depois dessa época, no início da década de 1970, que Clarice Lispector começou a despertar o interesse da crítica e da academia, quando foi lançada a obra A maçã no escuro, traduzida por Violante do Canto e publicada pela editora Gallimard. Esse lançamento mereceu as primeiras resenhas da imprensa francesa, publicadas em veículos como Magazine Littéraire e Le Monde (Pereira, 1995, p. 111).

A partir de 1978, após a morte da escritora, a editora Des Femmes-Antoinette Fouque decidiu editar toda a sua obra em francês. A primeira obra a sair pela editora foi A paixão segundo G.H., traduzida por Claude Farny. Esse lançamento marcou o segundo período na recepção de Clarice, quando a publicação de suas obras passou a gerar maior impacto. Não há como falar sobre esse momento da presença de Clarice Lispector na França sem mencionar sua grande patrona: Hélène Cixous. Cixous foi 
professora universitária, crítica literária, ensaísta, dramaturga e poeta. Teve participação decisiva na formação da Universidade Paris VIII, onde criou o Centro de Pesquisas em Estudos Femininos, sendo considerada por muitos uma das articuladoras da teoria feminista pós-estruturalista. Como professora universitária, divulgou a obra de Lispector em seus muitos seminários, que contavam com alunos do mundo inteiro. Antes de tomar conhecimento da obra de Clarice Lispector, Cixous trabalhava a feminilidade em textos escritos por homens, mas marcados pela presença feminina. No entanto, ao travar contato com a obra de Lispector, Cixous enfim encontrou uma escritora que lhe serviu de referência, contribuindo para os estudos do feminino na Universidade de Vincennes, que influenciaram toda uma geração de jovens feministas, como a americana Verena Conley ou a canadense Claire Varin. Os seminários de Hélène Cixous exerceram grande influência sobre a qualidade das obras de Lispector em francês, uma vez que, ao analisar as versões das obras da autora nos mínimos detalhes, Cixous levou a um maior apuro nas traduções, que se tornaram mais cuidadosas (Piza, 1987). A partir do trabalho de Cixous, Clarice Lispector passou a ser conhecida no Primeiro Mundo como uma escritora feminista.

O terceiro e último momento da recepção de Clarice Lispector na França é marcado pelo lançamento, em 2009, de uma biografia da autora brasileira escrita pelo norte-americano Benjamin Moser, o primeiro estrangeiro a escrever uma biografia de um autor brasileiro. Com seu livro, Moser conquistou grande sucesso editorial e impulsionou a divulgação da obra da autora para além do círculo acadêmico. Além da biografia, Moser traduziu para o inglês diversas obras de Lispector e organizou um volume com os 85 contos escritos pela autora que foi considerado um dos 100 melhores livros do ano pelo jornal The New York Times. O biógrafo de Lispector foi o responsável por finalmente aproximar a autora do público, não apenas nos EUA, mas em todo o mundo, inclusive na França. Diante da repercussão do trabalho de Moser na França, a editora Des Femmes-Antoinette Fouque decidiu reeditar as obras da autora entre 2012 e 2018, além de lançar Minhas queridas (2015), coletânea de cartas trocadas entre Clarice e suas irmãs, Todos os contos (2017), organizado por Moser, e Todas as crônicas (2019), organizado por Pedro Karp Vasquez. 
Quadro 15: Obras de Clarice Lispector traduzidas para o francês com os respectivos anos de publicação, tradutores, reedições e editoras.

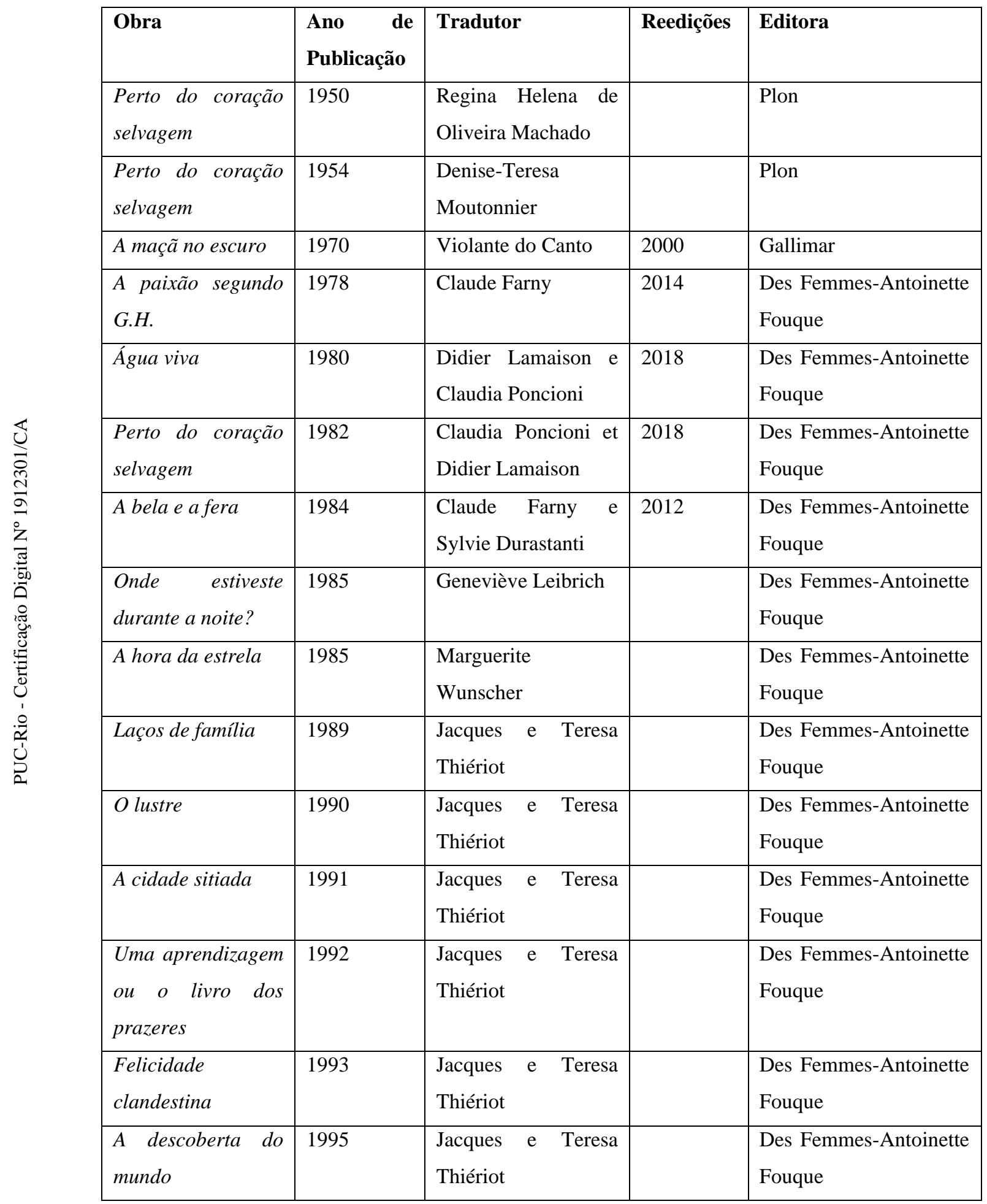




\begin{tabular}{|c|c|c|c|c|}
\hline Um sopro de vida & 1998 & $\begin{array}{lll}\text { Jacques } & \text { e } & \text { Teresa } \\
\text { Thiériot } & & \\
\end{array}$ & 2018 & $\begin{array}{l}\text { Des Femmes-Antoinette } \\
\text { Fouque }\end{array}$ \\
\hline $\begin{array}{l}\text { A vida íntima de } \\
\text { Laura }\end{array}$ & 2004 & $\begin{array}{lll}\text { Jacques e Teresa } \\
\text { Thiériot }\end{array}$ & 2018 & $\begin{array}{l}\text { Des Femmes-Antoinette } \\
\text { Fouque }\end{array}$ \\
\hline $\begin{array}{l}\text { Como nasceram as } \\
\text { estrelas }\end{array}$ & 2005 & $\begin{array}{lll}\text { Jacques } & \text { e } & \text { Teresa } \\
\text { Thiériot } & & \\
\end{array}$ & & $\begin{array}{l}\text { Des Femmes-Antoinette } \\
\text { Fouque }\end{array}$ \\
\hline Aprendendo a viver & 2012 & & & Rivages \\
\hline Minhas queridas & 2015 & $\begin{array}{l}\text { Claudia Poncioni e } \\
\text { Didier Lamaison }\end{array}$ & & $\begin{array}{l}\text { Des Femmes-Antoinette } \\
\text { Fouque }\end{array}$ \\
\hline $\begin{array}{l}\text { Cartas perto do } \\
\text { coração }\end{array}$ & 2016 & $\begin{array}{l}\text { Claudia Poncioni e } \\
\text { Didier Lamaison }\end{array}$ & & $\begin{array}{l}\text { Des Femmes-Antoinette } \\
\text { Fouque }\end{array}$ \\
\hline Todos os contos & 2017 & Oito tradutores & & $\begin{array}{l}\text { Des Femmes-Antoinette } \\
\text { Fouque }\end{array}$ \\
\hline Todas as crônicas & 2019 & 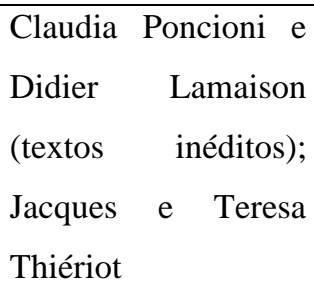 & & $\begin{array}{l}\text { Des Femmes-Antoinette } \\
\text { Fouque }\end{array}$ \\
\hline
\end{tabular}

Fonte: Elaborado pela autora da dissertação (2021)

\subsection{6.}

\section{Clarice Lispector nos EUA}

A década de 1960 marca a estreia em língua inglesa de Clarice Lispector, cuja obra A maçã no escuro foi traduzida por Gregory Rabassa, professor universitário e tradutor entre outros de Jorge Amado e Machado de Assis. Rabassa sentia profunda admiração por Lispector, como constatamos em um artigo publicado no jornal The New York Times, em 11 de março de 2005 (IHU, 2007), em que o tradutor afirmou ser a autora o equivalente a Kafka na literatura latino-americana. A admiração era mútua, uma vez que Lispector descreveu Rabassa como um tradutor "de primeira água ganhou o National Book Award do ano [1967], nos Estados Unidos” (Lispector, 2005, p. 117 apud Miroir, 2016, p. 78). Ainda na década de 1960, a poeta americana Elisabeth Bishop traduziu três contos de Lispector - a saber, "Uma galinha", "A menor mulher 
do mundo" e "Macacos" -, que foram publicados na revista The Kenyon Review em 1964.

Mas só na década de 1970 a autora conquistaria maior projeção no mundo anglo-saxão, com o início da série de traduções de suas obras empreendida pelo respeitado estudioso escocês Giovanni Pontiero. O tradutor se tornou conhecido principalmente por seu trabalho com dois autores de língua portuguesa: Clarice Lispector e José Saramago. As traduções de obras de Saramago renderam a Pontiero diversos prêmios importantes de tradução. De Lispector, Pontiero verteu, ao todo, seis obras em um período de vinte anos. São elas: os contos reunidos em Laços de família (1972); A maçã no escuro (1984), em retradução; A legião estrangeira (1986), outra coletânea de contos; A hora da estrela (1986), considerada por muitos sua obra-prima; Perto do coração selvagem (1990), seu romance de estreia; e, por último, A descoberta do mundo (1992), coleção de crônicas publicadas no Jornal do Brasil de 1967 a 1973. O obituário de Pontiero no jornal Independent afirmou ser ele "o mais competente tradutor da literatura em português do século XX, e um de seus defensores mais ardorosos"11 (Griffin, 1996, s. p.).

O trabalho de Pontiero com a obra de Lispector contou com muitos admiradores, dentre os quais Robyn Marsack (1997 apud Esteves, 2016, p.652), editor de A descoberta do mundo, que destacou a pesquisa meticulosa empreendida por Pontiero para sanar dúvidas, e Hilary Owen, que afirmou ainda a respeito da tradução da mesma obra:

Sempre consciente de que no estilo de prosa de Clarice "menos é mais", Giovanni sabiamente permite que as contradições e as ilogicidades da autora falem por si, resistindo à tentação comum de parafrasear ou explicar em demasia estruturas sintáticas simples que apresentam um paradoxo, como "o ator inglês é o homem mais sério da Inglaterra". (Owen, 1997, p. 612 apud Esteves, 2016, p. 653) 12 $^{2}$

11 "the ablest translator of 20th-century literature in Portuguese and one of its most ardent advocates."

12 Ever conscious that in Clarice's prose style "less is more", Giovanni wisely allows Clarice's contradictions and illogicalities to speak for themselves, resisting the common temptation to paraphrase or overexplain simple syntactical structures which present a paradox, such as "o ator inglês é o homem mais sério da Inglaterra". 
Além de tradutor, Pontiero foi também um grande patrono de autores da língua portuguesa, servindo de intérprete àqueles que visitavam a Grã-Bretanha, ou tentando convencer editores a publicarem autores desconhecidos no mundo anglo-saxão (Esteves, 2016, p. 22-23).

Todo esse empenho, no entanto, não foi capaz de protegê-lo de críticas, principalmente daquelas direcionadas a ele por aquele que se tornou outro grande patrono da obra de Clarice Lispector em língua inglesa: Benjamin Moser. Após a publicação, em 2009, de Why This World, a biografia de Lispector escrita por Moser que se tornaria um grande êxito editorial, o autor convenceu os editores da New Directions a publicarem retraduções de diversas obras da escritora, dentre as quais $A$ hora da estrela, traduzida primeiramente por Pontiero e retraduzida pelo próprio Moser. A rejeição de Moser à tradução de Pontiero para o romance de Lispector foi tamanha, que ele declarou ter sentido "dor de estômago quando as pessoas diziam que estavam lendo a obra. Não conseguia suportar! Portanto me vi na estranha condição de aconselhar as pessoas a não lerem um livro que eu estava desesperado para que lessem"13 (Esposito, 2015, s.p.).

Entre a escrita da biografia, a tradução e a supervisão da tradução de obras da escritora, Moser se debruçou sobre a obra de Lispector durante cerca de dez anos. Em entrevista publicada no site da revista The Paris Review, em agosto de 2015, ele explica por que escolheu Lispector, o que o levou a dedicar tantos anos de sua vida à obra da autora:

As pessoas têm mais com o que se preocupar na vida do que com uma brasileira morta de quem você insiste em falar. E acho importante para as pessoas que trabalham com literatura internacional evitar tratar do tema como uma obrigação desagradável como vejo acontecer em muitas discussões. Porque de fato não há nada em ser brasileiro, sueco ou coreano que torne um livro superior a outro existente no bom e velho inglês. Acho importante se perguntar, antes de começar, por que as pessoas deveriam dedicar seu tempo a esse livro e não a centenas de milhares de livros maravilhosos em inglês que ainda não leram. Eu consegui dedicar todos esses anos a Clarice porque acreditei que ela está entre um punhado de grandes artistas universais que formam, como os monumentos da Unesco, o patrimônio de toda a humanidade. Pensei que ela enriqueceria - e até mesmo salvaria - as vidas daqueles que a encontrassem. E se você

\footnotetext{
${ }^{13}$ my stomach ache when people would say they were reading it. I couldn't stand it! So I found myself in the weird position of telling people not to read a book that I was desperate for them to read.
} 
tem essa crença sobre um autor, então é claro que o trabalho [...] é entusiasmante e recompensador. (Esposito, 2015, s.p.) ${ }^{14}$

Moser, um profissional moderno e ciente da importância da divulgação de uma obra, não foi apenas biógrafo e tradutor de Lispector: ele promoveu a obra da autora e a biografia sobre a escritora que ele próprio escreveu, junto a editores, críticos e o público em geral. O próprio Moser explica sua estratégia de publicação e marketing das obras escritas ou organizadas por ele:

Enviei muitos e-mails sobre Clarice Lispector. E não se pode certamente desprezar ou desdenhar das pessoas que trabalham em publicidade e marketing e vendas — pode-se aprender muito com as pessoas cujo trabalho é dar telefonemas e enviar e-mails. [...] Digo isso porque costumo ficar chocado com a atitude condescendente que muitos escritores e tradutores, principalmente do mundo acadêmico, demonstram para com essas pessoas e o trabalho delas. (Esposito, 2015, s.p.) ${ }^{15}$

Enfim, não faltaram a Moser o desejo e a disposição para promover a obra de Clarice Lispector não apenas nos EUA, mas ao redor do mundo. Na disputa entre os dois tradutores, Pontiero e Moser, quem realmente ganhou foi a escritora, que contou com dois grandes patronos de suas obras no mundo anglo-saxão.

Dentre as obras de Clarice Lispector publicadas no mundo anglófono, três, da editora New Directions, contaram com o financiamento da FBN: A paixão segundo $G$. H. (2012), em tradução de Idra Novey, Um sopro de vida (2012), vertido por Johnny Lorenz e Todos os contos (2015), transposto por Katrina Dodson, todos sob supervisão

\footnotetext{
${ }^{14}$ People have more going on in their lives than the dead Brazilian lady you keep going on and on about. And I think it's important for people who work with international literature to avoid the eat-your-broccoli tone I see in a lot of these discussions. Because in fact there is nothing about being Brazilian or Swedish or Korean that makes a book superior to a book already sitting around in boring old English. I think it's important to ask yourself, before you start, why people should spend their time on this book and not on the hundreds of thousands of wonderful books in English that they haven't yet read. I was able to devote all these years to Clarice because I really believed that she was one of the handful of great universal artists who were, like the UNESCO monuments, the patrimony of all humanity. I thought she would enrich - and indeed save - the lives of those who would encounter her. And if you believe that about an author, then by all means the work of bringing across is tremendously thrilling and rewarding.

${ }^{15}$ Let's just say that I've sent a lot of e-mails on Clarice Lispector's behalf. And you have to enjoy sending them. And you certainly can't despise or look down on people who work in publicity and marketing and sales - you can learn a lot from the people whose job it is to make the phone calls and send the e-mails, professional bringers-across. I say this because I've often been appalled by the condescending attitude a lot of writers and translators, particularly from the academic world, display toward these people and their work.
} 
de Benjamin Moser. Esse apoio constitui uma exceção a uma tendência da instituição de diversificar seu apoio, destinando as bolsas de tradução prioritariamente a autores pouco conhecidos nos centros literários hegemônicos ou a escritores já consagrados nos principais centros, mas ainda sem penetração em centros periféricos.

Quadro 16: Obras de Clarice Lispector traduzidas para o inglês com os respectivos anos de publicação, tradutores, reedições e editoras.

\begin{tabular}{|c|c|c|c|c|}
\hline Obra & $\begin{array}{l}\text { Ano de } \\
\text { Publicação }\end{array}$ & Tradutor & Reedições & Editora \\
\hline A maçã no escuro & 1961 & Gregory Rabassa & 1984 & Alfred A.Knopf \\
\hline Laços de família & 1972 & $\begin{array}{l}\text { Giovanni } \\
\text { Pontiero }\end{array}$ & $\begin{array}{l}1984,1985, \\
1995\end{array}$ & $\begin{array}{lr}\text { University } & \text { of } \\
\text { Texas } & \text { Press } \\
(1972, & 1984, \\
1990), & \text { Carcanet } \\
\text { Press } & (1985, \\
1995) & \end{array}$ \\
\hline $\begin{array}{l}\text { Soulstorm (Via crucis do } \\
\text { corpo, Onde estivestes de } \\
\text { noite) }\end{array}$ & 1976 & Alexis Levitin & 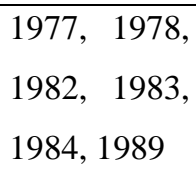 & New Directions \\
\hline A maçã no escuro & 1984 & $\begin{array}{l}\text { Giovanni } \\
\text { Pontiero }\end{array}$ & & $\begin{array}{l}\text { University of } \\
\text { Texas Press }\end{array}$ \\
\hline A legião estrangeira & 1986 & $\begin{array}{l}\text { Giovanni } \\
\text { Pontiero }\end{array}$ & 1987,1992 & $\begin{array}{lr}\text { Carcanet } & \text { Press } \\
(1986, & 1987), \\
\text { New Directions } \\
(1992)\end{array}$ \\
\hline A hora da estrela & 1986 & $\begin{array}{l}\text { Giovanni } \\
\text { Pontiero }\end{array}$ & $\begin{array}{l}1987,1989, \\
1992\end{array}$ & $\begin{array}{lr}\text { Carcanet } & \text { Press } \\
(1986, & 1989, \\
1992), & \text { Paladin } \\
\text { Grafton } & \text { Books } \\
(1987), & \text { New } \\
\text { Directions } & \text { (1992) }\end{array}$ \\
\hline $\begin{array}{l}\text { Uma aprendizagem ou o } \\
\text { livro dos prazeres }\end{array}$ & 1986 & $\begin{array}{l}\text { Richard A. } \\
\text { Mazzara }\end{array}$ & & $\begin{array}{ll}\text { University } & \text { of } \\
\text { Texas Press } & \end{array}$ \\
\hline A paixão segundo G.H. & 1988 & Ronald W. Sousa & & $\begin{array}{l}\text { University of } \\
\text { Minnesota Press }\end{array}$ \\
\hline
\end{tabular}




\begin{tabular}{|c|c|c|c|c|}
\hline Água viva & 1989 & $\begin{array}{l}\text { Elizabeth Lowe e } \\
\text { Earl Fitz }\end{array}$ & & $\begin{array}{l}\text { University of } \\
\text { Minnesota Press }\end{array}$ \\
\hline Via crucis do corpo & 1989 & Alexis Levitin & & New Directions \\
\hline Perto do coração selvagem & 1990 & $\begin{array}{l}\text { Giovanni } \\
\text { Pontiero }\end{array}$ & & Carcanet Press \\
\hline A descoberta do mundo & 1992 & $\begin{array}{l}\text { Giovanni } \\
\text { Pontiero }\end{array}$ & & Carcanet Press \\
\hline A hora da estrela & 2011 & Benjamin Moser & 2014 & New Directions \\
\hline Água viva & 2012 & $\begin{array}{l}\text { Benjamin Moser } \\
\text { e Stefan Tobler }\end{array}$ & 2014 & New Directions \\
\hline $\begin{array}{l}\text { Um sopro de vida: } \\
\text { pulsações }\end{array}$ & 2012 & $\begin{array}{l}\text { Benjamin Moser } \\
\text { e Johnny Lorenz }\end{array}$ & 2014 & New Directions \\
\hline A paixão segundo G.H. & 2012 & $\begin{array}{l}\text { Benjamin Moser } \\
\text { e Idra Novey }\end{array}$ & 2014 & New Directions \\
\hline Perto do coração selvagem & 2012 & $\begin{array}{l}\text { Benjamin Moser } \\
\text { e Elison Entrekin }\end{array}$ & 2014 & New Directions \\
\hline O lustre & 2018 & $\begin{array}{l}\text { Magdalena } \\
\text { Edwards }\end{array}$ & & New Directions \\
\hline
\end{tabular}

Fonte: Elaborado pela autora da dissertação (2021)

\subsection{7.}

\section{Machado de Assis, Jorge Amado, Clarice Lispector e as bolsas de tradução da FBN}

Machado de Assis, Clarice Lispector e Jorge Amado são autores que conquistaram seu espaço entre os cânones da literatura universal e, portanto, a quase totalidade da obra desses autores já foi traduzida na França e nos EUA, o que parece explicar a baixa demanda por bolsas. Toda a ajuda que a obra desses autores canônicos recebe atualmente da FBN é consequência da consagração que obtiveram em grandes centros literários e destina-se à divulgação, principalmente, em centros periféricos. Esses autores, embora não cheguem a ser populares na França ou nos Estados Unidos, alcançaram um espaço entre os clássicos da literatura universal, fato que os diferencia dos demais escritores brasileiros. Para manterem tal status, esses autores precisam do apoio de patronos e reescritores que tornem sua obra atual e conhecida entre as 
sucessivas gerações. Machado de Assis, Clarice Lispector e Jorge Amado despertam o interesse de centros literários periféricos distantes física e culturalmente do Brasil como a China, a Etiópia e Israel, ao contrário de outros autores brasileiros de muito prestígio em território brasileiro, como Rubem Fonseca, Carlos Drummond de Andrade, Cristóvão Tezza e Érico Veríssimo, cuja circulação no exterior fica bastante restrita aos centros culturais hegemônicos e à América Latina.

\section{3.}

\section{As antologias em língua inglesa e a formação de cânones}

A FBN vem subsidiando não apenas obras dos mais diversos autores, mas também antologias organizadas em diversas línguas para a promoção de nossos escritores no exterior. Ao todo, foram financiadas 40 antologias de autores brasileiros para várias línguas. As antologias são uma boa oportunidade para apresentar autores ainda não consagrados fora de nossas fronteiras, portanto, sem uma obra completa em circulação no exterior. No entanto, uma antologia sempre implica uma seleção por parte dos organizadores, que, como reescritores da nossa literatura, participam da formação de cânones em diversos sistemas de literatura traduzida ao redor do mundo. As seleções, porém, costumam gerar polêmicas, uma vez que, mesmo contando com júris diversificados, representam as escolhas apenas de um grupo.

A fim de debater os critérios que norteiam as antologias da literatura brasileira publicadas no exterior, analiso, a seguir, algumas antologias publicadas fora do nosso território. Há antologias editadas em diversas línguas, porém, por não ser possível examinar todas elas, restrinjo-me às antologias publicadas em inglês, uma língua hipercentral, com o apoio de bolsas de tradução da FBN. Em comum, todas as antologias estudadas têm o desejo de romper com os estereótipos e clichês aos quais nossa literatura é associada e promover uma imagem mais abrangente de nossa cultura. 
3.3.1.

\section{Granta 121: o apoio a novos autores e a renovação dos cânones}

Além de apoiar autores já consagrados no Brasil, as bolsas de tradução também contemplam escritores em início de carreira, contribuindo para a renovação e ampliação dos cânones da literatura brasileira traduzida no exterior. Uma das iniciativas mais importantes de promoção de novos autores no exterior foi $o$ financiamento da publicação do número 121 da revista literária britânica Granta. A Granta foi criada por estudantes da Universidade de Cambridge em 1889, e já lançou autores da importância de Michael Frayn, Ted Hughes e Sylvia Plath, todos alunos de Cambridge. Posteriormente, a revista ampliou seu escopo e passou a publicar autores oriundos de fora da universidade, como Martin Amis, Julian Barnes, Saul Bellow, Milan Kundera, Ian McEwan, Gabriel García Márquez e Salman Rushdie, firmando-se como uma prestigiosa revista literária.

A partir de 2009, a revista iniciou um processo de internacionalização, lançando edições em espanhol, búlgaro, português, norueguês, sueco e chinês. Em julho de 2012, a Granta publicou, com o apoio de uma bolsa de tradução concedida pela FBN, uma edição especial com autores de nossa literatura intitulada "Os melhores jovens escritores brasileiros", voltada para os novos talentos das nossas letras. Essa edição foi publicada em um momento em que o Brasil atraía as atenções do mundo inteiro ao sediar eventos como a Copa do Mundo de 2014 e os Jogos Olímpicos de 2016, aproveitando um período de fortalecimento da economia e de uma política externa que alçou o país a uma posição de protagonismo nas relações internacionais.

A antologia da Granta reuniu textos inéditos de 20 autores brasileiros nascidos depois de 1972, selecionados entre 247 trabalhos inscritos. Do total de inscritos, cerca de 70 textos foram pré-selecionados, e só esses foram levados à avaliação de um júri, formado pelos críticos Beatriz Bracher, Benjamin Moser, Cristovão Tezza, Italo Moriconi, Manuel da Costa Pinto, Marcelo Ferroni e Samuel Titan Júnior. A partir da leitura, cada membro do júri elaborou uma lista de vinte autores levada ao corpo de jurados que, em reunião, realizou a seleção final. De acordo com os editores da revista, nove autores receberam cinco, seis ou até sete votos e foram incluídos automaticamente 
na seleção. Alguns receberam quatro votos, o que levou a um debate entre os jurados sobre a relevância desses nomes para a antologia. Apesar dos debates que cercaram as escolhas, ao final da primeira rodada, o corpo de jurados já aprovara 17 nomes (Publishnews, 2012). Todos os 20 jovens escritores selecionados já tinham pelo menos um conto publicado por uma editora brasileira, e alguns até já haviam recebido prêmios literários importantes. Cabe destacar a importância, para a renovação da representatividade da literatura brasileira e dos nossos cânones no exterior, dos membros do júri, encarregados de selecionar os autores que fariam parte da antologia de novos escritores brasileiros.

De acordo com Roberto Feith, diretor geral da editora Objetiva, que publica a Granta no Brasil, "os textos escolhidos foram selecionados exclusivamente com base em sua qualidade literária. Questões como o estado de origem, quais editoras já publicaram os autores, nada disso foi considerado. A única coisa que contou foi a qualidade dos textos" (Publishnews, 2012). A seleção, no entanto, suscitou críticas, em grande parte devido à falta de diversidade dos autores, predominantemente, brancos, heterossexuais e residentes do eixo Rio-São Paulo, definidos por um dos tradutores participantes do projeto, Stefan Tobler, como jovens de classe média viajados, que constituem um universo bastante limitado (Williams, 2017, p. 109).

Quadro 17: Autores publicados na Granta com respectivas obras, tradutores e relação de bolsas da FBN concedidas para obras diversas.

\begin{tabular}{|c|c|c|c|}
\hline Autor & Texto & Tradutor & Bolsas FBN \\
\hline Michel Laub & "Animais" & $\begin{array}{l}\text { Margaret Jull } \\
\text { Costa }\end{array}$ & $\begin{array}{l}\text { Alemanha (2012), Espanha } \\
\text { (2013), França (2014, 2016), } \\
\text { Israel (2014), Itália (2013), } \\
\text { Noruega (2014), Países Baixos } \\
\text { (2013), Reino Unido (2014), } \\
\text { Suécia (2014) }\end{array}$ \\
\hline Miguel del Castillo & "Violeta" & $\begin{array}{l}\text { Amanda } \\
\text { Hopkinson }\end{array}$ & - \\
\hline $\begin{array}{l}\text { Tatiana Salem } \\
\text { Levy }\end{array}$ & "O Rio sua" & Alison Entrekin & $\begin{array}{l}\text { Albânia (2017), Austrália } \\
\text { (2015), Croácia (2016), Egito } \\
\text { (no prelo), Romênia (2013) }\end{array}$ \\
\hline Ricardo Lísias & "Evo Morales" & Nick Caistor & Argentina (2014) \\
\hline
\end{tabular}




\begin{tabular}{|c|c|c|c|}
\hline Carola Saavedra & "Toda terça" & Alison Entrekin & $\begin{array}{l}\text { Alemanha (2012), França } \\
\text { (2013), Costa Rica (2014), Chile } \\
(2015)\end{array}$ \\
\hline Vanessa Barbara & "Noites de alface" & Katrina Dodson & França (2015), Suécia (2014) \\
\hline Cristhiano Aguiar & "Teresa" & Daniel Hahn & - \\
\hline Laura Erber & $\begin{array}{l}\text { "Aquele vento na } \\
\text { praça" }\end{array}$ & Anna Kushner & - \\
\hline Leandro Sarmatz & "O conde" & Peter Bush & - \\
\hline Julián Fuks & "O jantar" & Johhny Lorenz & $\begin{array}{l}\text { Romênia (2012), Egito (no } \\
\text { prelo), França (2018), Itália (no } \\
\text { prelo) }\end{array}$ \\
\hline Emilio Fraia & "Temporada" & Katrina Dodson & - \\
\hline Antonio Prata & $\begin{array}{l}\text { "Valdir Peres, } \\
\text { Juanito e Poloskei" }\end{array}$ & Daniel Hahn & - \\
\hline $\begin{array}{l}\text { Antônio } \\
\text { Xerxenesky }\end{array}$ & $\begin{array}{l}\text { "Amanhã, quando } \\
\text { acordar" }\end{array}$ & Ina Rilke & $\begin{array}{l}\text { Espanha (2014), França }(2014, \\
2016,2018)\end{array}$ \\
\hline $\begin{array}{l}\text { Javier Arancibia } \\
\text { Contreras }\end{array}$ & "A febre do rato" & Jethro Soutar & - \\
\hline Chico Mattoso & "Longe de Ramiro" & $\begin{array}{l}\text { Clifford } \quad \text { E. } \\
\text { Landers }\end{array}$ & - \\
\hline Carol Bensimon & "Faíscas" & Beth Fowler & $\begin{array}{l}\text { Espanha }(2014,2015), \text { Estados } \\
\text { Unidos (2016) }\end{array}$ \\
\hline Luisa Geisler & "Leão" & Ana Fletcher & - \\
\hline J.P. Cuenca & "Antes da queda" & $\begin{array}{l}\text { Clifford } \\
\text { Landers }\end{array}$ & $\begin{array}{l}\text { Alemanha (2012, 2013), } \\
\text { Espanha (2012), Estados Unidos } \\
\text { (2013), Finlândia (2014), } \\
\text { França (2014), Romênia (2015), } \\
\text { Suécia (2015) }\end{array}$ \\
\hline Vinicius Jatobá & "Natureza morta" & Jethro Soutar & - \\
\hline Daniel Galera & "Apneia" & Stefan Tobler & $\begin{array}{l}\text { Alemanha }(2013, \\
\text { Espanha } 2017), \\
\text { França (2013, 2014, 2018), } \\
\text { (2014), Noruega (2014), Países } \\
\text { Baixos (2013), Polônia (2016), } \\
\text { Reino Unido (2013), Romênia } \\
\text { (2014), Suécia (2014) }\end{array}$ \\
\hline
\end{tabular}

Fonte: Elaborado pela autora da dissertação com base na revista Granta (2021) 
De acordo com Roberto Feith e Marcelo Ferroni, editor da revista no país e do selo Alfaguara, as histórias "não transmitem a imagem de uma nação tropical idealizada", ${ }^{16}$ consequência do desejo da nova geração de escritores brasileiros de se afastar dos estereótipos resultantes de uma visão parcial do Brasil, difundida pelas principais culturas receptoras, que vinha caracterizando a literatura brasileira há longo tempo. Na apresentação da revista, os editores descrevem os novos autores de nossa literatura da seguinte forma:

Essa geração está menos interessada do que as anteriores na questão da identidade brasileira. Por muitos anos essa identidade foi definida por meio de um retorno à terra ou ao Brasil "autêntico", onde a busca pelas origens culturais podia ser empreendida sem as influências corruptoras do mundo. Os jovens escritores brasileiros não estão especialmente preocupados em separar o que é interior do que vem de fora. Filhos e filhas de uma nação mais próspera e aberta, eles são cidadãos do mundo, além de brasileiros. (Feith; Ferroni, 2012) ${ }^{17}$

Devido ao prestígio da revista, essa edição exerceu grande influência sobre os patronos das letras brasileiras no exterior, tanto que, após sua publicação, dentre os 20 jovens autores nela incluídos, 10 tiveram obras traduzidas para outra língua mediante a concessão de uma até 13 bolsas de tradução da FBN, distribuídas como podemos observar no quadro 17. Vale ressaltar que, dos 10 autores apoiados pela instituição, sete foram publicados na França, o que comprova o interesse dos franceses pela literatura brasileira contemporânea.

16 [...] do not convey an image of an idealized, tropical nation.

17 This is a generation less interested than those that have preceded it in the question of a Brazilian identity. For many years this identity was often defined through a return to the land or to the 'authentic' Brazil, where the search for cultural origins could be made outside the corrupting influences of the world at large. Young Brazilian writers are not especially concerned with parsing what derives from within and what comes from outside. Sons and daughters of a nation that is more prosperous and open, they are citizens of the world, as well as Brazilians. 
3.3.2.

\section{Antologias da revista Litro dedicadas ao Brasil}

Desde 2005, a revista Litro: Stories Transport You, cuja proposta é oferecer uma oportunidade a novos escritores bem como celebrar autores já consagrados, é distribuída gratuitamente nas ruas de Londres aos usuários de transportes públicos ou em formato online na internet. A Litro publica prosa e poesia em todos os seus números. Além de incluir artigos sobre o Brasil e os escritores brasileiros em várias de suas edições, a revista já publicou, com o apoio da FBN, dois números dedicados exclusivamente ao Brasil: o 114, Rio, e o 129, The Women's Writing Issue.

Lançada em 2012, a edição de número 114 sobre o Rio de Janeiro lembrou a realização de grandes eventos como a Rio +20 e a homenagem ao Brasil na Feira do Livro de Frankfurt, ambos em 2013, a Copa do Mundo em 2014 e os Jogos Olímpicos em 2016. Em virtude da realização de tantos eventos no país, e particularmente no Rio de Janeiro, a cidade e o país estavam na moda, e a iniciativa de ampliação da oferta de bolsas da FBN à época permitiu à literatura aproveitar esse momento em que os olhos do mundo inteiro se voltavam para nós. Dos 10 autores presentes na coletânea, sete nunca haviam sido apresentados ao público anglofalante, o que reforça o caráter inovador da revista ao permitir que os leitores travem um primeiro contato com autores que poderiam vir a interessá-los. Além de microcontos, contos e poesias, a revista traz um artigo de Damian Platt, identificado como especialista em Brasil, sobre um episódio na guerra entre facções de traficantes de drogas ocorrido à época em que o país foi escolhido para sediar as Olimpíadas. A violência no Rio parece ser um tema inescapável quando se fala sobre a cidade, o que já se tornou um clichê.

Quadro 18: Autores publicados na Litro 114 com respectivos textos e tradutores.

\begin{tabular}{|l|l|l|l|}
\hline Autor & Texto & Tradutor & Gênero \\
\hline Nilton Resende & "A fresta" & Alison Entrekin & Prosa \\
\hline Lúcia Bettencourt & "Verão" & Kim Hastings & Prosa \\
\hline $\begin{array}{l}\text { Leonardo Villa- } \\
\text { Forte }\end{array}$ & "Monólogo a dois" & Jaciara Topley Lira & Prosa \\
\hline João Paulo Cuenca & "No hay banda" & Jethro Soutar & Prosa \\
\hline
\end{tabular}




\begin{tabular}{|l|l|l|l|}
\hline Sérgio Rodrigues & $\begin{array}{l}\text { "O relato de Stapfnunsk, um homem } \\
\text { de bem" }\end{array}$ & Sérgio Rodrigues & Prosa \\
\hline $\begin{array}{l}\text { Tatiana Salem } \\
\text { Levy }\end{array}$ & "Deserto" & Jaciara Topley Lira & Prosa \\
\hline Antônio Moura & "A espera" & Stefan Tobler & Poesia \\
\hline Angélica Freitas & "Aos onze anos" & Hilary Kaplan & Poesia \\
\hline Angélica Freitas & $\begin{array}{l}\text { "A mina de ouro de minha mãe e } \\
\text { minha tia" }\end{array}$ & Hilary Kaplan & Poesia \\
\hline Adriana Lisboa & "Altitude" & Diane Grosklaus Whitty & Poesia \\
\hline Adriana Lisboa & "O presente" & Diane Grosklaus Whitty & Poesia \\
\hline Ramon Mello & "Telhas" & $\begin{array}{l}\text { Thereza Rocque da } \\
\text { Motta }\end{array}$ & Poesia \\
\hline Ramon Mello & "Havaianas" & $\begin{array}{l}\text { Thereza Rocque da } \\
\text { Motta }\end{array}$ & Poesia \\
\hline
\end{tabular}

Fonte: Elaborado pela autora desta dissertação com base na revista Litro 114 (2021)

Em 2013, a revista dedicou ainda outro número à literatura produzida no Brasil. À época, o Brasil, um país de cultura machista, contava com representantes do sexo feminino na presidência do país, na chefia do Ministério da Cultura e na presidência da Academia Brasileira de Letras. Essa situação pode ter despertado o interesse da Litro, que decidiu dedicar um número unicamente às escritoras brasileiras. Das nove autoras presentes nessa antologia, apenas duas, Ana Paula Maia e Marília Garcia, já haviam sido publicadas em inglês, confirmando o pioneirismo da publicação.

Essa edição traz ainda uma curiosidade: os textos, em sua maioria, foram traduzidos por alunas de português e respectiva professora da Universidade de Oxford, uma experiência enriquecedora para a formação de novas tradutoras do português. Para muitas dessas alunas, esse trabalho constituiu uma primeira experiência de vivência tradutória profissional.

Quadro 19: Autoras publicadas na Litro 129 com respectivos textos e tradutores.

\begin{tabular}{|l|l|l|l|}
\hline \multicolumn{1}{|c|}{ Autora } & \multicolumn{1}{|c|}{ Texto } & \multicolumn{1}{|c|}{ Tradutor } & Gênero \\
\hline Luisa Geisler & "Coríntios I" & Gitanjali Patel & Prosa \\
\hline Juliana Frank & "Lavie na luz medonha" & Hannah Bowers & Prosa \\
\hline
\end{tabular}




\begin{tabular}{|l|l|l|l|}
\hline Paloma Vidal & "Así es la vida" & Hilary Kaplan & Prosa \\
\hline Miriam Mambrini & "Breu" & Gitanjali Patel & Prosa \\
\hline Ana Paula Maia & "Desmedido Roger" & Claire Williams & Prosa \\
\hline Ana Paula Maia & "Esporo" & Sarah Jacobs & Prosa \\
\hline Carola Saavedra & "Convivência" & Clelia Goodchild & Prosa \\
\hline Ana Rüsche & "O grande plugue" & Jenny Cearns & Poesia \\
\hline Marília Garcia & "Uma equação no Hyde Park" & Eloise Stevens & Poesia \\
\hline Marina Colasanti & "Porta do armário aberta" & Diane Whitty & Poesia \\
\hline Marina Colasanti & "Ao hálito das montanhas & Diane Whitty & Poesia \\
\hline
\end{tabular}

Fonte: Elaborado pela autora da dissertação com base na revista Litro 129 (2021)

\subsection{3.}

\section{Other Carnivals: New Stories from Brazil}

A antologia Other Carnivals foi publicada pela editora Full Circle, de Liz Calder, em 2013, para acompanhar e celebrar a primeira edição da Flipside, festa literária que tem lugar na costa sudeste da Inglaterra e que, assim como a Flip, foi fundada por Calder. A antologia, contendo 12 contos, foi organizada e traduzida por Ángel Gurría-Quintana - escritor, editor e tradutor literário, vinculado à Universidade de Cambridge - para distribuição durante a festa literária entre aqueles que participaram de uma oficina em celebração aos escritores brasileiros.

Quatro dos autores apresentados em Other Carnivals (Adriana Lisboa, Bernardo Carvalho, Ferréz e Milton Hatoum) compareceram à festa e leram trechos de suas histórias, reforçando a tendência de editores estrangeiros de buscarem autores que possam participar de eventos internacionais e promover as próprias obras.

Os contos são uma amostra representativa de várias gerações de escritores brasileiros, das mais diversas regiões e com diferentes estilos. São todos autores conhecidos no Brasil, e alguns até mesmo já publicados no exterior, como Milton 
Hatoum e Adriana Lisboa; alguns começando a carreira e outros já premiados. Como os escritores incluídos não têm muito em comum, além do fato de serem brasileiros, o critério de seleção parece ter sido a diversidade, com o objetivo de formar um conjunto representativo e variado do que se faz no Brasil em termos de literatura.

Quadro 20: Autores publicados na antologia Other Carnivals e respectivos textos.

\begin{tabular}{|l|l|}
\hline Autor & Texto \\
\hline Milton Hatoum & "Um enterro e outros carnavais" \\
\hline Bernardo Carvalho & "A língua do futuro" \\
\hline Tatiana Salem Levy & "Tempo perdido" \\
\hline Cristovão Tezza & "O corte" \\
\hline Andréa del Fuego & "Camping Calamares" \\
\hline Beatriz Bracher & "Suli" \\
\hline Marcelino Freire & "Solar dos príncipes" \\
\hline João Anzanello Carrascoza & "Espinho" \\
\hline Ferréz & "Vizinhos" \\
\hline André Sant'Anna & "Deus é bom no 8" \\
\hline Adriana Lisboa & "Aquele ano em Rishikesh" \\
\hline Reinaldo Moraes & "Flipando na Flip, ou À procura do farelo perdido" \\
\hline
\end{tabular}

Fonte: Elaborado pela autora da dissertação com base na antologia Other Carnivals (2021)

\subsection{4.}

\section{Antologias ambientadas no Rio de Janeiro}

Em 2014, a FBN financiou duas antologias de contos ambientados no Rio de Janeiro: The Book of Rio: A City in Short Fiction e Rio Noir. O primeiro comentário que se pode tecer sobre as duas obras relaciona-se à quase ausência de mulheres entre os escritores convidados. Em The Book of Rio, apenas Patrícia Melo, que costuma ser associada ao gênero policial, e Elvira Vigna estão presentes ao lado de oito representantes do sexo masculino. Em Rio Noir, a proporção é ainda menor: apenas duas mulheres entre doze homens. O ponto positivo a ser apontado em relação a The Book of Rio é o número acentuado de tradutores que tomaram parte no projeto, alguns 
deles inclusive pouco conhecidos, o que pode contribuir para aumentar o número de poliglotas do português, agregando prestígio à nossa língua.

Rio Noir é uma coletânea de contos organizada por Tony Bellotto para a editora Akashic Books, com o propósito de figurar na série Noir, composta por mais de cem antologias de mistério e crime ambientadas em diferentes cidades, dentre as quais o Rio de Janeiro e São Paulo. A antologia, cujos contos se passam em diferentes bairros da cidade do Rio de Janeiro, inclui autores consagrados no gênero, como Luiz Alfredo Garcia-Roza, Patrícia Melo e o próprio Bellotto, e estreantes, como Arthur Dapieve e Arnaldo Bloch. A obra contém, lado a lado, uma breve biografia de cada um dos autores bem como do tradutor dos contos, Clifford E. Landers, valorizando o trabalho deste ao nivelá-lo em importância e visibilidade aos próprios escritores. Landers é um tradutor premiado que já verteu romances de autores como Rubem Fonseca, Jorge Amado, João Ubaldo Ribeiro e Paulo Coelho, bem como autor da obra Literary Translation: A Practical Guide (Multilingual Matters, 2001).

Quadro 21: Autores publicados na antologia Rio Noir com respectivos textos.

\begin{tabular}{|l|l|}
\hline Autor & Texto \\
\hline Adriana Lisboa & "O enforcado" \\
\hline Tony Bellotto & "Coroas saradas" \\
\hline Alexandre Fraga dos Santos & "Canibal de Ipanema" \\
\hline Luiz Alfredo Garcia-Roza & "O butim" \\
\hline MV Bill & "O retorno" \\
\hline Luiz Eduardo Soares & "Fim de semana em São Conrado" \\
\hline Guilherme Fiuza & "RJ-171" \\
\hline Arthur Dapieve & "Táxi argentino" \\
\hline Victoria Saramago & "Ponto cego" \\
\hline Arnaldo Bloch & "O enigma da vitrola" \\
\hline Marcelo Ferroni & "Tangerina tango" \\
\hline Flávio Carneiro & "A espera" \\
\hline Raphael Montes & "A história de Georges Fullar" \\
\hline Luis Fernando Veríssimo & "O lenhador" \\
\hline
\end{tabular}

Fonte: Elaborado pela autora da dissertação com base na antologia Rio Noir (2021) 
$\mathrm{Na}$ introdução, Bellotto tenciona deixar para trás os clichês da Cidade Maravilhosa de belas paisagens, mas acaba resvalando para um outro clichê associado ao Rio de Janeiro, a violência, ao afirmar que:

Este não é um guia turístico. A cidade que se descortina no livro que o leitor tem em mãos é um outro Rio.

Ainda que nas páginas deste Rio Noir as famosas paisagens estejam presentes, o que se revela aqui é um mundo de vultos, sangue, intriga, violência, desvãos e mistério (e também de humor, é claro, como só poderia ser num empreendimento em que cariocas estejam envolvidos). Há muito o Rio deixou de ser uma idílica cidade de encantos turísticos, e as cenas de crimes protagonizadas por traficantes selvagens, policiais violentos e políticos corruptos atestam o fato com assustadora regularidade em noticiários por todo o planeta. Nos dias de hoje, a imagem da cidade de lindas praias, mulheres sensuais, gays animados e malandros simpáticos está inapelavelmente atrelada a tiroteios e disputas sangrentas entre facções criminosas. A cidade partida, fraturada entre uma classe média cosmopolita e uma população desassistida em comunidades miseráveis, tornou-se o retrato mais expressivo de um país de enorme desigualdade social e gritante violência. (Bellotto, 2014, p. 5)

A outra antologia dedicada ao Rio de Janeiro, The Book of Rio, também faz parte de uma série de antologias sobre cidades do mundo, publicada pela editora independente Comma Press, de Manchester, que já conta com volumes dedicados a Tóquio, Gaza, Cartum, Daca, Istambul, Liverpool e Leeds. Diferentemente da antologia anteriormente citada, essa série não está circunscrita a contos de mistério e crime, mas todos os contos estão, de certa forma, associados à cidade do Rio de Janeiro. $\mathrm{Na}$ introdução, o organizador, Toni Marques, curador da Festa Literária das Periferias (FLUPP), conta a história da Cidade Maravilhosa desde a chegada dos europeus e apresenta alguns dos escritores conhecidos por ambientarem suas histórias no Rio de Janeiro, cidade que, muitas vezes, é quase um personagem para Machado de Assis, Clarice Lispector e Rubem Fonseca, entre outros. Assim como Belotto, Marques faz questão de deixar claro que os contos e excertos de textos incluídos passam longe dos clichês ao declarar que

não há equivalente à Bossa Nova na literatura brasileira: nenhuma tomada da classe média descontraída, descolada e sexy das áreas mais afluentes da cidade, nenhuma maravilha natural de cartão postal (a Bossa Nova é conhecida por sua celebração das 
paisagens do Rio), nenhum olhar chauvinista para um dado estilo de vida privilegiado. ${ }^{18}$ (Marques, 2014, p. 7)

$[\ldots]$

as mulheres não fazem topless nas praias, e os homens não tomam banho de sol de sunga o dia inteiro como se estivessem em Ibiza. ${ }^{19}$ (Marques, 2014, p. 9)

No entanto, assim como Belotto, Marques acaba destacando a violência que castiga a cidade, e pela qual o Rio vem se tornando conhecido, bem como outras dificuldades enfrentadas pelo carioca:

E infelizmente nós ainda não podemos ser uma cidade sem a vergonha das gangues de traficantes de drogas que matam uns aos outros, dos políticos corruptos e incompetentes, dos policiais sujos e assassinos, de um sistema de esgoto inadequado, de um sistema de transporte público lotado, de multidões de pedestres imprudentes, de uma profusão de maus motoristas, de pessoas que jogam lixo no chão, de grande quantidade de escolas públicas dilapidadas, diversos hospitais públicos infectados e assim por diante. ${ }^{20}$ (Marques, 2014, p. 10)

Ou seja, de acordo com o antologista, os textos se afastam dos clichês e não escondem o sórdido submundo de violência e desigualdade social. No entanto, essas antologias acabam por corroborar um clichê mais contemporâneo da cidade, associada atualmente à violência extrema.

Quadro 22: Autores publicados na antologia The Book of Rio com respectivos textos e tradutores.

\begin{tabular}{|l|l|l|}
\hline Autor & Texto & Tradutor \\
\hline Cesar Cardoso & "Para Copacabana, com amor" & Ana Fletcher \\
\hline João Gilberto Noll & "Alguma coisa urgentemente" & Sophie Lewis \\
\hline Domingos Pellegrini & "A maior ponte do mundo" & Jon S. Vincent \\
\hline Nei Lopes & "Cântico dos cânticos" & Amanda Hopkinson \\
\hline Luiz Ruffato & "Sorte teve a Sandra" & Jethro Soutar \\
\hline
\end{tabular}

18 there is no Bossa Nova equivalent in Brazilian literature: no easy-going, smart, sexy, middle-class take on the city's most affluent areas, no mesmerizing picture-postcard natural wonders (Bossa Nova is known for its celebration of Rio's landscapes), no chauvinist look at a given, privileged lifestyle.

${ }^{19}$ There are no clichés here either: women are not topless on the beaches, and men don't sunbathe in thongs all day long as if they were in Ibiza.

${ }^{20}$ And unfortunately we still can't be a city without the shame of drug-trafficking gangs killing each other, corrupt and incompetent politicians, crooked and murderous cops, an inadequate sewage system, an overcrowded public transport system, throngs of jaywalkers, a multitude of bad drivers, blasé litterbugs, a vast amount of run-down public schools, a rotten number of infectious public hospitals, and so on, and so on. 


\begin{tabular}{|l|l|l|}
\hline Sergio Sant’Anna & "Estranhos" & Julia Sanches \\
\hline Marcelo Moutinho & "Dezembros” & Kimberly M. Hastings \\
\hline João Ximenes Braga & "A mulher que transou com o cavalo" & Zoë Perry \\
\hline Patrícia Melo & "Eu te amo" & Daniel Hahn \\
\hline Elvira Vigna & "Lugares, no meio de tudo" & Lucy Greaves \\
\hline
\end{tabular}

Fonte: Elaborado pela autora da dissertação com base na antologia The Book of Rio (2021)

Ao examinar essas antologias, concluímos que a literatura brasileira contemporânea que vem sendo apoiada pela FBN e apresentada no exterior (em língua inglesa) é rica e prolífica, no sentido de que parece impossível classificá-la segundo temas, estilos ou motivações. No entanto, as escolhas dos editores não se destacam pela diversidade, já que carecem de maior presença de mulheres e de minorias. Além disso, descobrimos que os autores brasileiros, os tradutores do português para o inglês e os editores do mercado editorial anglo-saxão parecem ter aproveitado bem a oportunidade que a ampliação do programa de bolsas da FBN e a visibilidade alcançada pelo Brasil na década de 2010 ofereceram. Com certeza, o número de traduções de autores brasileiros cresceu de maneira significativa nas últimas décadas, e o público passou a ter acesso a uma maior variedade de escritores brasileiros novos e consagrados em território brasileiro. 


\section{4.}

\section{A patronagem da FBN: o apoio aos tradutores}

Este capítulo é dedicado às iniciativas da FBN que visam a apoiar os tradutores da literatura brasileira, complementando a análise dos demais projetos da instituição direcionados à penetração da produção literária do Brasil no exterior. Antes, no entanto, parece oportuno traçar um perfil desses agentes culturais que, além da atividade de tradução, desempenham muitas vezes importante papel como patronos ao promover autores e obras junto a editores e ao público.

Em primeiro lugar, é importante compreender como o tradutor literário se relaciona com a atividade tradutória. De acordo com Gisèle Sapiro (2014, p. 83), a tradução não é uma atividade totalmente profissional, tendo sido durante séculos desempenhada de forma amadorística e gratuita por vocação ou hobby. Com o tempo e em algumas culturas, a tradução passou por um processo de profissionalização quando, por um lado, alguns tradutores começaram a se especializar em tradução e a viver de seu ofício, e por outro lado, passaram a reivindicar direitos e remuneração digna. No entanto, veremos a seguir que, entre os tradutores da literatura brasileira, a atividade tradutória continua a ser, na maioria das vezes, uma atividade secundária, com a qual não podem contar como meio principal de subsistência. Além disso, a tradução costuma gozar de pouco prestígio social, embora certos tradutores sejam muito valorizados, em virtude de um currículo de traduções realizadas ou como consequência do renome conquistado em outras atividades, como a de escritor ou poeta.

\section{1.}

\section{Quem traduz as nossas letras: um perfil dos tradutores da literatura brasileira}

O que pensam aqueles que traduzem para outras línguas as obras da literatura brasileira? Que papel a tradução ocupa na vida deles? Como se relacionam com o Brasil e a literatura aqui produzida? Essas e outras perguntas despertaram a curiosidade de um grupo de alunos do curso de Letras da Universidade Federal de Santa Catarina que, 
em 2013, entrevistaram 12 tradutores da literatura brasileira dos principais centros literários da Europa e dos EUA contemplados com uma bolsa de residência no Brasil oferecida pela FBN (Bruchard et al., 2017). Foram entrevistados tradutores que atuam nos seguintes países: França, Espanha, Itália, Alemanha, Grécia, Inglaterra, EUA e Canadá. Segue-se uma análise de algumas das informações obtidas nesses depoimentos.

Um dos temas abordados pelos entrevistadores diz respeito à relação dos entrevistados com a profissão de tradutor. Descobrimos que a tradução raramente é a principal atividade profissional entre os tradutores da literatura brasileira. De acordo com a tradutora francesa Paula Anacaona, é

difícil ganhar a vida com tradução literária. O tradutor é um freelance, o que tem a vantagem de ser uma atividade bem flexível, mas flexível também no sentido negativo: se não chamam, você não tem trabalho. De modo que os tradutores literários que conheço são geralmente professores universitários, ou têm alguma outra ocupação. (Bruchard et al., 2017, p.186)

Entre todos os entrevistados, apenas dois declararam viver de tradução, mesmo assim um deles se sustenta à custa de traduções técnicas, realizando traduções literárias apenas nas horas vagas. Essa situação é reforçada pelos dados obtidos no banco de dados online publicado no site Conexões Itaú Cultural que resulta de uma pesquisa com 347 agentes culturais relacionados à nossa literatura no exterior, sejam eles professores-pesquisadores e/ou tradutores. Mais de 50\% (221) desses profissionais atuam como tradutores, mas somente cerca de $21 \%$ deles (74) declararam ser esta a sua única atividade profissional. Muitos dos entrevistados (147) são professorespesquisadores que também atuam como tradutores, atividade considerada por eles secundária.

Outra entrevistada, a grega Maria Papadima, é um exemplo típico do tradutor atraído pela literatura brasileira, como constatamos na seguinte declaração:

A tradução não é minha atividade principal; sou professora universitária no Departamento de Francês da Universidade de Atenas; ensino Teoria e Prática da Tradução. Traduzo os autores de que gosto, pelo prazer de traduzi-los; dedico a cada tradução o tempo necessário para fazer um bom trabalho; não traduzo best-sellers; raramente traduzo por encomenda; faço a minha própria escolha; mesmo as minhas 
primeiras traduções foram propostas minhas aos editores. (Bruchard et al., 2017, p. 247)

Papadima é também um bom exemplo de patronagem exercida pelo tradutor, uma vez que ela faz as próprias escolhas das obras que deseja traduzir e convence os editores a investirem em suas apostas. Essa situação não é incomum entre os entrevistados, como esclarece Paula Anacaona (Bruchard et al., 2017, p. 187): “O tradutor na França tem muito este papel de apresentar obras ao editor; é bastante comum o tradutor sugerir um título ao editor; existe espaço para isso."

Os tradutores não são apenas patronos, são também beneficiados pela patronagem de governos e instituições que oferecem bolsas, prêmios, programas de residência e oficinas. Todos os tradutores entrevistados mencionam prêmios e outras iniciativas de incentivo à atividade tradutória, à exceção de Manuele Masini, que afirma não haver na Itália nenhum programa regular de apoio a tradutores.

Nos depoimentos encontramos também muitos exemplos de atividades de reescrita da literatura brasileira, paralelas à tradução, exercidas pelos entrevistados durante os processos de produção e divulgação da obra traduzida, como constatamos em outro trecho do depoimento de Paula Anacaona:

Quando trabalhava para a Les Allusifs, eu fazia os releases para a imprensa dos livros que traduzia. Fui eu que escolhi os títulos. Quando havia uma mesa-redonda com jornalistas, entrevistas, eu ia; como os jornalistas não falavam português, eu ia ao Skype traduzir para eles... É verdade que isso tudo é muito, agradável, mas, bem, acho que as editoras se aproveitam muito, muito, dos tradutores. [...] E isso acontece muito. Talvez não nas grandes editoras, que têm dinheiro para pagar um estagiário que faça os releases para a imprensa, mas em todas as pequenas editoras, que estão lutando para sobreviver, o tradutor tem que ajudar. Mesmo porque, segundo elas, se você quer vender o livro que traduziu, precisa ajudar. Acho que é uma prática muito comum, realmente. (Bruchard et al., 2017, p. 188)

Situação semelhante já viveu o também francês Philippe Poncet:

No caso da grande maioria dos editores que me contrataram como tradutor, eu fazia tudo, além da tradução, ou quase, para a preparação do manuscrito: contracapa, argumento editorial para o distribuidor, documentos para a mídia escrita ou audiovisual, pedido de subvenção para convidar o autor, tradução simultânea quando o autor chegava a Paris etc. Cansativo, mas sensacional, de modo geral. (Bruchard et al., 2017, p. 256) 
Estes são alguns exemplos que demonstram como os tradutores que trabalham com a literatura brasileira investem seu tempo em atividades não remuneradas relacionadas à promoção e à publicação de uma obra em tradução, com o objetivo de ver o autor que traduziram conquistar sucesso e visibilidade na cultura de recepção, atuando como patronos e reescritores da nossa literatura. $\mathrm{O}$ trabalho de reescrita deles não se limita a textos curtos, como orelhas ou releases para a imprensa, mas envolve muitas vezes a elaboração de prefácios ou posfácios, como, por exemplo, ocorre com Papadima, ou a organização de antologias, atividade já desempenhada por seis dentre os 12 tradutores entrevistados.

Os tradutores também se mostram cientes das dificuldades encontradas para difundir nossa literatura, e demonstram conhecimento do mercado para os autores brasileiras no país em que atuam. Como exemplo, Paula Anacaona afirma que

da literatura brasileira, os franceses conhecem Jorge Amado, Paulo Coelho, mas, fora isso, ninguém na França conhece a literatura brasileira. Nas livrarias, ela fica misturada nas prateleiras com a literatura argentina, mexicana, cubana... Como se fosse tudo a mesma coisa. (Bruchard et al., 2017, p. 185)

Portanto, na perspectiva de Anacaona: (i) apenas dois escritores brasileiros são mencionados como conhecidos do público em geral na França, ficando os demais autores restritos quase que exclusivamente aos círculos acadêmicos, dependentes da divulgação de professores universitários e tradutores; e (ii) a literatura brasileira é apresentada como parte do grupo de literaturas latinas, provavelmente por uma questão de aproximação geográfica, sem ser alvo de um trabalho de apresentação e divulgação voltado exclusivamente para si, que valorize suas peculiaridades.

Nos Estados Unidos a situação não é muito diferente. De acordo com Clifford E. Landers,

já que Jorge Amado nos deixou há bastante tempo, eu diria que Clarice Lispector é a autora que gera mais atenção nos meios acadêmicos. Para o americano menos estudioso, o único nome da literatura nacional de reconhecimento no momento é Paulo Coelho. (Bruchard et al., 2017, p. 216) 
Os depoimentos desses profissionais dedicados à tradução de obras literárias brasileiras sugerem, portanto, que a renovação de nomes da literatura brasileira consagrados no exterior se faz de forma muito lenta e se dá principalmente a partir do meio acadêmico. Entre o público leigo, o principal nome é o fenômeno de vendas Paulo Coelho. Landers também comenta os estereótipos aos quais nossa literatura está atrelada, afirmando que

lamentavelmente, continua prevalecendo nos Estados Unidos o estereótipo do Brasil folclórico, "o país do carnaval" ou do futebol. O americano típico, mesmo dentre os de maior escolaridade, sabe muito pouco sobre a cultura de qualquer país latino além dos pontos turísticos. (Bruchard et al., 2017, p. 216.

Também são interessantes os depoimentos sobre a forma como os estrangeiros veem a cultura brasileira de maneira geral e a literatura em particular; dentre eles, destaco o testemunho da espanhola Teresa Mararrantz Lópes: “O Brasil [...] desperta muita simpatia no meu país. Interessa o futebol, a política, a música, mas o público em geral não se interessa pela literatura.” (Bruchard et al., 2017, p. 236) Ou, a declaração de Paula Anacaona de que "para os jornalistas, para a elite cultural, literária, intelectual francesa, o brasileiro é músico, não é escritor. O brasileiro é engraçado, tem alegria, mas não é sério. Isso prejudica muito.” (Bruchard et al., 2017, p. 186)

Na visão desses tradutores, portanto, outros aspectos de nossa cultura despertam mais interesse do que a literatura, que ainda goza de pouca visibilidade. Além disso, como país periférico, o Brasil é pouco conhecido, predominando nos centros hegemônicos os clichês aos quais estamos sujeitos.

Outro tema abordado nas entrevistas foi a questão da visibilidade do tradutor. No Brasil, encontramos poucas menções ao tradutor, cujo nome recebe pouco ou nenhum destaque na própria obra traduzida ou mesmo em críticas literárias. Situação semelhante parecem viver os tradutores que atuam na França, como esclarece Philippe Poncet:

A priori, existe reconhecimento dos tradutores literários na França. Os nomes dos tradutores, ao menos, são mencionados nos livros. Mas nos sites, blogs, teses de doutorado ou outros tipos de documentos mencionando livros e bibliografia, o tradutor 
raramente aparece. Quem lembra que o tradutor de La peste, de Camus, foi Graciliano Ramos? (Bruchard et al., 2017, p. 257)

Já nos EUA e na Inglaterra, a situação parece ser particularmente dramática. Como comenta Nicholas Caistor a respeito da Inglaterra:

Muitas vezes não se menciona o nome do tradutor nas resenhas, e às vezes a própria editora não o coloca no livro traduzido. Existe ainda a ideia de que uma obra traduzida venderá menos que uma obra escrita em inglês, por isso às vezes tentam esconder o fato de que o livro é de um autor estrangeiro. (Bruchard et al., 2017, p. 193)

E nas palavras do norte-americano Clifford E. Landers,

infelizmente, o mercado comercial nos EUA é avesso às traduções e, portanto, as editoras se esforçam para disfarçar a origem da obra. Quer dizer, mal acusam o fato de ela ser vertida de outra língua. Para se certificar do nome do tradutor, às vezes é preciso procurar, quase com lupa, na página de catalogação na publicação (CIP). Somente as editoras universitárias dão o devido respeito ao tradutor. (Bruchard et al., 2017, p. 218)

Esses depoimentos nos levam a concluir que a própria condição da obra como produto de uma literatura estrangeira afugenta o público leigo de língua inglesa, portanto os editores tentam escamotear essa condição. O historiador, tradutor e teórico da tradução americano Lawrence Venuti descreve esse fenômeno do mundo anglosaxão e suas consequências:

Um texto traduzido, seja prosa ou poesia, ficção ou não ficção, é considerado aceitável pela maioria dos editores, revisores e leitores quando sua leitura é fluente, quando a ausência de peculiaridades linguísticas ou estilísticas o torna transparente, transmitindo a aparência de que ele reflete a personalidade ou a intenção do escritor ou o significado essencial do texto estrangeiro - a aparência, em outras palavras, de que a tradução não é de fato uma tradução, mas o "original". A ilusão da transparência é efeito da estratégia de tradução fluente, do esforço do tradutor para garantir uma leitura fácil ao aderir ao uso corrente [do inglês], manter a sintaxe contínua, fixar um significado preciso. (Venuti, 2008 [1995], p. 1) ${ }^{21}$

${ }^{21}$ A translated text, whether prose or poetry, fiction or nonfiction, is judged acceptable by most publishers, reviewers and readers when it reads fluently, when the absence of any linguistic or stylistic peculiarities makes it seem transparent, giving the appearance that it reflects the foreign writer's personality or intention or the essential meaning of the foreign text - the appearance, in other words, that the translation is not in fact a translation, but the "original." The illusion of transparency is an effect of a fluent translation strategy, of the translator's effort to insure easy readability by adhering to current usage, maintaining continuous syntax, fixing a precise meaning. 
Mais adiante, Venuti explica o que significa uma tradução fluente no universo anglo-saxão:

Uma tradução fluente é imediatamente reconhecida e compreendida, "familiarizada", domesticada, não "desconcertante[mente]" estrangeira, capaz de oferecer ao leitor sem obstruções "acesso a grandes pensamentos", ao que está "presente no original". Sob o regime da tradução fluente, o tradutor trabalha para tornar seu trabalho "invisível", produzindo o efeito ilusório de transparência que simultaneamente mascara seu status como uma ilusão: o texto traduzido parece "natural", isto é, não traduzido. (Venuti, 2008 [1995], p. 5$)^{22}$

Portanto, os tradutores britânicos e estadunidenses trabalham para tornar seu trabalho invisível, uma vez que, na maneira de ver de editores e leitores, quanto mais invisível o tradutor, mais fluente a tradução e "presumivelmente, mais visível o escritor ou o sentido do texto estrangeiro" (Venuti, 2008 [1995], p. 1). ${ }^{23}$ Além disso, pode-se concluir que as traduções fluentes, cujas marcas da cultura de origem são apagadas durante a tradução, deixam de levar inovações à cultura de chegada, já que “concentram-se geralmente no sentido da prosa e na interpretação, e negligenciam a imitação da forma e do modo". ${ }^{24}$ (Venuti, 2008 [1995], p. 6)

A relação com os editores foi mais um dos assuntos abordados no conjunto de entrevistas. Esse relacionamento varia bastante de uma editora para outra, sendo que editoras mais comerciais parecem dar menos voz aos tradutores, enquanto as editoras que publicam alta literatura conferem a eles maior autonomia, como esclarece o inglês Nicholas Caistor:

O tradutor tem autonomia para traduzir como ele achar melhor, seguindo ou não as normas do editor, dependendo do acordo entre eles, mas o editor também tem liberdade para mudar a tradução ao seu gosto. No entanto, é tudo um processo de negociação, assim como a relação com o revisor. Mas as editoras comerciais não perguntam a opinião do tradutor, que não tem espaço para escrever prefácios ou algum outro tipo de paratexto, dar sugestões para a capa ou ilustrações. (Bruchard et al., 2017, p. 194)

\footnotetext{
${ }^{22}$ A fluent translation is immediately recognizable and intelligible, "familiarised," domesticated, not "disconcerting[ly]" foreign, capable of giving the reader unobstructed "access to great thoughts," to what is "present in the original." Under the regime of fluent translating, the translator works to make his or her work "invisible," producing the illusory effect of transparency that simultaneously masks its status as an illusion: the translated text seems "natural," that is, not translated.

${ }^{23}$ presumably, the more visible the writer or meaning of the foreign text.

${ }^{24}$ have generally concentrated on prose-meaning and interpretation, and neglected the imitation of form and manner.
} 
Ou seja, a relação dos tradutores com as editoras de alta literatura é mais pessoal, e é nelas que eles gozam de mais prestígio e respeito.

Há casos em que a editora realiza grandes interferências. O americano Clifford E. Landers, por exemplo, já viu uma das obras traduzidas por ele sofrer uma intervenção radical para atender ao gosto do público alvo:

uma editora pode ser, às vezes, muito radical fazendo cortes que acabam alterando a tradução. Foi o que aconteceu com Vozes do deserto, de Nélida Piñón, cuja tradução sofreu cortes e alterações posteriores porque o texto foi considerado excessivamente erotizado e não adequado ao gosto do leitor americano. (Bruchard et al., 2017, p. 220)

Enfim, o que esse depoimento revela é que, entre o tradutor e a editora, pode existir uma relação pessoal e respeitosa ou uma relação meramente comercial em que, às vezes, nem mesmo a obra traduzida é digna de consideração.

Por fim, cabe destacar o papel do tradutor na comunicação não apenas entre duas línguas, mas entre duas culturas, visão difundida a partir da década de 1960, pois já em 1954, Joseph B. Casagrande afirmou que "na verdade não se traduzem línguas e sim culturas" (Casagrande, 1954, p.338 apud Baker, 1999, p. 22). Até então, o tradutor era valorizado por características como o conhecimento das línguas de partida e de chegada, a busca por equivalência entre as duas línguas de trabalho, a fidelidade a significados supostamente depositados no texto e a capacidade de não deixar marcas pessoais ou culturais no trabalho. Seu objetivo era transmitir uma mensagem de uma língua para a outra com o mínimo de interferência possível. A partir de então, o tradutor passou a ser visto por muitos estudiosos como um mediador cultural que torna compreensível aos leitores da cultura de recepção os valores e o contexto social da comunidade em que o texto original foi escrito, promovendo o entendimento mútuo entre duas culturas diversas e buscando integrar conhecimentos e experiências. Mais do que um mediador linguístico, o tradutor é um mediador cultural, uma vez que os sentidos atribuídos a palavras e expressões em uma língua são facilmente compreendidos pelos indivíduos que partilham convenções, acordos, regras, costumes e hábitos característicos de uma cultura, mas podem passar despercebidos ou causar estranhamento àqueles que não pertencem à cultura e desconhecem o contexto de produção desses sentidos (Darin, 2006, p. 68). A tradutora Paula Anacaona, por 
exemplo, parece compreender bem seu papel como mediadora entre duas culturas: "Ser tradutora é, para mim, como ser uma ponte entre a França e o Brasil. É poder compartilhar meu conhecimento, dar aos franceses que não falam português, que não podem entender, a possibilidade de conhecer" (Bruchard et al., 2017, p. 176).

O sentimento de intermediar a comunicação entre dois povos e de sentir necessidade de levar a cultura brasileira até seus conterrâneos também é compartilhado por Clifford E. Landers: “A motivação principal continua sendo a mesma desde o dia em que comecei: a vontade de difundir para meus compatriotas um conhecimento máximo de uma cultura vibrante, viva e fascinante - a brasileira" (Bruchard et al., 2017, p. 214).

Tradutores como Anacaona e Landers atuam, de certa forma, como embaixadores da cultura brasileira no país em que vivem e trabalham, reforçando a importância do intercâmbio cultural que pode representar a vivência de um tradutor estrangeiro em nossa terra, experiência proporcionada pelas iniciativas da FBN que trataremos a seguir.

\section{2. O Programa de Residência de Tradutores Estrangeiros no Brasil}

Este programa, que vigora desde 2012, tem por objetivo conceder bolsas a tradutores estrangeiros com a finalidade de apoiar o custeio de períodos de residência desses profissionais no Brasil. A bolsa cobre as despesas do tradutor durante o período de permanência no Brasil e os custos de passagens aéreas e terrestres, nacionais e internacionais, até um limite estabelecido no edital mais recente (2016) do programa, apresentado como Anexo C desta dissertação.

Os tradutores interessados em participar do programa devem estar em processo de tradução, do português para qualquer idioma, de uma obra de literatura ou humanidades, especialmente nos seguintes gêneros: romance, conto, poesia, crônica, infantil e/ou juvenil, teatro, obra de referência, ensaio literário, ensaio de ciências sociais, ensaio histórico, ensaio de vulgarização científica e antologia de poemas e contos, integrais ou em parte. Vale salientar que, assim como o programa de bolsas de 
tradução, o programa de residência de tradutores não contempla o segmento de obras técnico-científicas.

Ao candidatar-se à bolsa, o solicitante deve apresentar:

(i) carta de apresentação pessoal, currículo e amostra de $10 \%$ da obra já traduzida com o texto correspondente em português, itens que ajudam a instituição na avaliação da competência profissional do candidato;

(ii) plano de trabalho para o período de residência, que deve incluir o número de dias que o candidato pretende permanecer no país, possíveis itinerários e deslocamentos dentro do território nacional, além de um cronograma de atividades das quais o candidato pretende participar. $\mathrm{O}$ itinerário proposto pode incluir cidades em diferentes regiões do país, de acordo com o universo da obra e do autor traduzido e com a necessidade de visitar instituições e travar contato com interlocutores relevantes para o trabalho. O plano deve incluir ainda uma estimativa dos custos de transporte aéreo e terrestre;

(iii) carta de apresentação e catálogo da editora estrangeira. Esse item ajuda a avaliar a editora que, juntamente com a FBN, desempenha o papel de agente de patronagem ao arcar com os custos de publicação da obra não relacionados à tradução;

(iv) cópia do contrato com a editora estrangeira, item que garante que a tradução já esteja em andamento, conforme exigência inicial para o recebimento da bolsa, e que atinja o público leitor, objetivo final da instituição;

(v) cópia do contrato de cessão de direitos autorais da obra firmado entre a editora e os autores ou seus representantes legais, caso a obra não esteja em domínio público, visando a evitar que, mesmo que indiretamente, a instituição se envolva em questões jurídicas relacionadas a direitos autorais.

As bolsas concedidas financiam, parcial ou totalmente, as despesas necessárias à permanência do tradutor no Brasil em um período específico durante o qual, como contrapartida, ele se compromete a participar de eventos promovidos pela FBN, como debates com autores e tradutores, oficinas de tradução e visitas a instituições culturais.

Os pedidos de bolsa feitos até o momento foram avaliados por uma comissão formada por tradutores, professores e/ou pesquisadores brasileiros da área de literatura 
e tradução e presidida por um representante da FBN - que julgou as solicitações de acordo com os seguintes critérios:

(i) a importância da obra para a promoção e a divulgação da cultura e da literatura brasileiras no exterior. A FBN prioriza autores e países nunca antes apoiados por suas bolsas (Lima; Salgado, 2015, s. p.), portanto o mérito do projeto é determinado principalmente por este critério;

(ii) a consistência do plano de trabalho e a necessidade da pesquisa in loco inerente ao projeto, exigência que contempla a relevância da vivência no Brasil para que o tradutor atue como um mediador cultural no intercâmbio entre a cultura brasileira e a cultura de recepção;

(iii) o índice de dificuldade linguística da tradução, visando a sanar dúvidas linguísticas que podem surgir ao longo do trabalho por meio da convivência com a cultura de origem;

(iv) o currículo do tradutor, como um meio de julgar a capacidade do profissional de desempenhar seu trabalho a contento.

O edital do programa de bolsas de residência determina que, em caso de empate, deve prevalecer o projeto que receber a maior nota no critério (i) e, em seguida, nos critérios (ii), (iii) e (iv).

De acordo com os próprios tradutores que já participaram do programa, ele representa uma grande oportunidade de conhecer o país e sua cultura, e se tornar, dessa forma, não só um tradutor especializado em duas línguas, mas um intérprete entre duas culturas, um mediador cultural, como afirma Wanda Jakob:

Acredito que a vivência no país de origem da obra é uma experiência importante e extremamente útil. Uma temporada no Brasil durante a qual é possível traduzir e viver a cultura da obra traduzida, falando com as pessoas que desenvolvem e vivenciam essa cultura, pode facilitar um mergulho profundo no texto e na sua linguagem. Gírias, expressões de humor e certas manifestações de cultura que não são facilmente encontradas na internet - tudo isso só é descoberto no próprio país. (Bruchard et al., 2017, p. 211)

O francês Dominique Nédellec destaca ainda como vantagens da residência no Brasil a possibilidade de, durante o processo de tradução, conviver com o autor e conhecer locais citados na obra, traduzindo 
nas melhores condições possíveis, com visitas a alguns lugares mencionados no livro e com a muito valiosa oportunidade de me encontrar com o próprio autor in loco, para sessões de trabalho. Nada melhor do que conversas ao vivo para esclarecer dúvidas e acertar pormenores. (Bruchard et al., 2017, p. 244)

Pode-se dizer que esse programa tem por objetivo não apenas preparar tradutores do português, língua que, como qualquer outra, tem seu prestígio atrelado, em grande parte, ao número de poliglotas que a dominam (Casanova, 2002, p. 35-36), mas também formar intérpretes da cultura brasileira, profissionais conscientes de que ao tradutor não basta apenas conhecer uma língua estrangeira, mas também a cultura da qual a obra a ser traduzida é fruto.

O programa ainda abre portas aos seus participantes para que tomem parte de diversas iniciativas de intercâmbio no Brasil que beneficiam não apenas o próprio tradutor residente, mas também professores, pesquisadores, alunos e profissionais da tradução, como constatamos no depoimento de Clifford E. Landers, que ministrou palestras e ofereceu oficinas de tradução para alunos e professores em sua passagem por Florianópolis e a quem

pareceu muito atraente ter a chance de interação com jovens universitários de graduação e pós na Universidade Federal de Santa Catarina (UFSC), onde passei uma semana na belíssima cidade de Florianópolis, e com todos da universidade conectados com a programação. (Bruchard et al., 2017, p. 216-217)

Vale ainda ressaltar que a FBN, ao conceber o programa de residência, pensou em criar uma casa para receber os tradutores, como já existem semelhantes na França, na Alemanha e na Suíça, e, para tanto, buscou o apoio de associações de tradutores existentes no Brasil, mas o projeto não foi levado adiante.

Por fim, interessa ainda destacar que o programa de residência de tradutores estrangeiros contou até o momento com três editais, com duração de um ano cada, publicados pela FBN nos anos de 2012, 2014 e 2016, e, embora o último edital do programa tenha vindo a público há cinco anos, de acordo com uma mensagem de correio eletrônico (2020) do coordenador do Programa de Apoio à Tradução da FBN, Fabio Lima, a instituição não tenciona interrompê-lo, portanto outros editais deverão ser publicados no futuro. 


\section{3.}

\section{Os eventos direcionados aos tradutores}

Os editais do programa de residência de tradutores estrangeiros no Brasil previam a participação dos tradutores residentes em eventos promovidos pela FBN, sempre em parceria com outras instituições. Esses eventos, que ocorreram de 2012 a 2017, tiveram por objetivo oferecer aos participantes do programa, além de um mergulho em nossa cultura proporcionado pela vivência no Brasil, algum conhecimento sobre o ofício de traduzir, uma vez que os tradutores literários, em sua maioria, não costumam ter formação específica em tradução, mas em áreas afins, como literatura. Os tradutores da literatura brasileira, portanto, costumam iniciar a prática da tradução munidos de conhecimentos sobre a literatura e a cultura do Brasil, mas ainda não formados como profissionais da tradução. Além disso, os eventos cumpriam o objetivo de aproximar os tradutores residentes e promover a convivência e a troca de ideias, oportunidades raras em uma profissão cujo trabalho é tão solitário. A fim de alcançar esses objetivos, a FBN e seus parceiros promoveram, a partir de 2012, uma série de atividades voltadas para a reflexão e o aprimoramento da prática tradutória.

Em parceria com a Universidade Federal Fluminense (UFF) e outras instituições, a FBN, além de alguns eventos pontuais, como debates e mesas-redondas em feiras e festivais literários, já organizou, até o momento:

(i) Edições anuais do Colóquio Intermediações Culturais, evento realizado na cidade de Paraty, no Rio de Janeiro, por ocasião da Festa Literária Internacional de Paraty (Flip), com a participação de professores, tradutores, escritores, editores e agentes literários, que abordaram o tema da tradução de diferentes perspectivas;

(ii) O seminário "A Formação do Tradutor", sediado pela própria FBN e pela UFF, entre os dias 19 e 22 de fevereiro de 2013. Nesse evento, que reuniu escritores, como Rubens Figueiredo e Ana Paula Maia, tradutores, como a alemã Wanda Jakob e o argentino Christian de Nápoli, e professores, como Marcia Martins e Paulo Henriques Britto, da PUC-Rio, Suzana Kampff 
Lages, da UFF, e Walter Costa, da UFSC, debateram temas como a relação entre o escritor e seu tradutor, a formação do tradutor e a tradução de obras brasileiras no exterior;

(iii) Oficinas de tradução literária da língua portuguesa para o alemão, o espanhol, o francês, o inglês, e vice-versa, que tiveram lugar entre os anos de 2012 e 2017.

\subsection{1.}

\section{As oficinas de tradução}

As oficinas de tradução favorecem a troca de ideias e experiências e o trabalho em conjunto. Nesses eventos, tradutores iniciantes têm a oportunidade de encontrar seus colegas mais experientes e, com estes, refletir sobre diferentes aspectos da atividade tradutória, além de trabalhar lado a lado. Nas oficinas, todos os participantes são ativos, isto é, seja apresentando textos para discussão em grupo ou debatendo soluções para textos alheios, nenhum tradutor se limita apenas a absorver conhecimentos, uma vez que as oficinas têm uma proposta colaborativa. Além da convivência com os colegas, os participantes, muitas vezes, têm a oportunidade de interagir com outros profissionais relevantes para a carreira de um tradutor, como escritores, revisores e editores. Esse tipo de experiência ainda é rara entre os tradutores, mas de grande importância para a formação desses profissionais.

Há vários formatos de oficinas de tradução, dentre os quais a FBN e a UFF elegeram, para as oficinas que organizaram com outros parceiros, o formato vice-versa, que consiste em trabalhar com um par de línguas, sendo o português sempre uma das línguas a constituir o par. A escolha do alemão, do francês, do espanhol e do inglês para formar dupla com o português nas oficinas vice-versa não parece ter sido aleatória. De acordo com o Index Translationum, essas são as línguas de chegada do maior número de traduções no mundo. São também, de acordo com Pascale Casanova (2002), algumas das línguas de mais prestígio internacional por contarem com grande número de poliglotas e serem as línguas em que foram escritos muitos dos clássicos da literatura mundial. A tradução de autores e obras da literatura brasileira para essas línguas 
dominantes no espaço de trocas literárias representa, por um lado, a consagração de nossos escritores e, por outro, um grande passo para a tradução para outras línguas dominadas, já que são muito comuns as traduções indiretas a partir de textos em línguas dominantes.

As próximas seções descrevem três oficinas de tradução promovidas pela $\mathrm{FBN}$ e seus parceiros com o objetivo de oferecer informações mais detalhadas sobre um tipo de evento que vem se tornando uma medida importante na formação dos profissionais de tradução e uma ação indispensável na troca de conhecimentos entre tradutores.

Quadro 23: Oficinas de tradução organizadas pela FBN em parceria com outras instituições.

\begin{tabular}{|l|l|l|}
\hline Oficina & Local & Ano \\
\hline Oficina português-alemão e vice-versa & Paraty, RJ & 2012 \\
\hline Oficina português-espanhol e vice-versa & Porto Alegre, RS & 2012 \\
\hline Oficina português-francês e vice-versa & Paraty, RJ & 2013 \\
\hline Oficina português-inglês e vice-versa & Paraty, RJ & 2014 \\
\hline Oficina português-alemão e vice-versa & Curitiba, PR & 2014 \\
\hline Oficina português-inglês e vice-versa & Fundação Biblioteca Nacional, RJ & 2016 \\
\hline Oficina português-inglês e vice-versa & Casa Guilherme de Almeida, SP & 2016 \\
\hline Oficina português-espanhol e vice-versa & Fundação Biblioteca Nacional, RJ & 2017 \\
\hline
\end{tabular}

Fonte: Elaborado pela autora da dissertação (2021)

\subsubsection{1.}

\section{Oficina de tradução português-alemão e vice-versa}

As oficinas de tradução português-alemão no formato vice-versa congregam tradutores nativos das duas línguas que, durante uma semana, apresentam e discutem seus respectivos projetos de tradução. Esse parece ser o método ideal para aprimorar textos e capacitar tradutores, além de promover o intercâmbio e a formação de redes e fóruns de tradução.

As oficinas vice-versa entre o Brasil e a Alemanha buscam uma alternância entre os dois países (um ano no Brasil, o outro na Alemanha). A primeira oficina nesse par se realizou em julho de 2012, em Paraty, no Rio de Janeiro, por ocasião da Festa Literária Internacional de Paraty (Flip) e pouco antes da Bienal do Livro do Rio. O 
evento contou com a participação de 14 tradutores, entre brasileiros falantes do português, com um projeto de tradução de um autor alemão em andamento, e nativos do alemão, envolvidos na tradução da obra de um autor brasileiro para sua própria língua. No ano seguinte, em outubro de 2013, a oficina teve uma segunda edição em Berlim, na Alemanha, pouco antes da Feira do Livro de Frankfurt que homenageou o Brasil. Nessa ocasião, os tradutores puderam visitar a Feira e participar de encontros com autores e lançamentos de livros. Buscando sempre variar a localização geográfica de modo a ampliar o raio de ação, os organizadores decidiram levar a oficina de tradução ao encontro da Associação Latino-Americana de Estudos Germanísticos (Aleg), realizado em Curitiba, em setembro de 2014, com o intuito de aproveitar a presença de professores, estudantes e estudiosos da língua alemã e a oferta variada de palestras e eventos. A quarta oficina de tradução português-alemão e vice-versa foi realizada na Casa de Tradutores Looren, na Suíça, em outubro de 2015, e incluiu pela primeira vez tradutores de Portugal, além de brasileiros e alemães. Os parceiros na organização e no financiamento desses eventos têm sido o Fundo Alemão para Tradução e o Instituto Goethe, assim como a FBN e a UFF, que contribuíram para a realização das oficinas em Paraty e Curitiba.

A ideia de organizar a primeira oficina surgiu em um momento em que o Brasil acabara de ser escolhido como o país a ser homenageado na edição de 2013 da Feira do Livro de Frankfurt e, diante dessa oportunidade de assumir o protagonismo no evento mais importante do calendário editorial mundial, a FBN decidiu aprimorar o programa de bolsas de tradução, já desenvolvido pela instituição desde 1991, e investir em diferentes iniciativas de estímulo à tradução e à promoção da literatura do país no exterior. Cerca de 250 milhões de pessoas no mundo falam o português. No entanto, quase 20 anos depois da última homenagem ao Brasil em Frankfurt, que teve lugar em 1994, a tradução de livros brasileiros para o alemão retrocedeu, sendo suplantada por obras dos países da Europa Oriental, que passaram a suscitar mais interesse depois da queda do Muro de Berlim. Diante desse quadro, havia a grande expectativa de que a homenagem em 2013 voltasse a impulsionar o interesse pela literatura brasileira. De fato, a tradução de autores brasileiros recebeu um grande impulso nos anos de 2012 a 2014 em virtude da homenagem da Feira de Frankfurt e dos programas de fomento à 
tradução da FBN, o que só confirma a importância da patronagem do governo brasileiro às nossas letras.

Uma das propostas do formato de oficina vice-versa é trabalhar textos em processo de tradução antes que sejam publicados, colaborando para oferecer aos leitores um produto final de qualidade. A oficina também tem por objetivo promover um debate entre tradutores experientes e principiantes sobre os problemas enfrentados ao longo do trabalho, examinando as nuances e as possibilidades nas duas línguas, as expressões idiomáticas e os trechos de difícil tradução, além de promover o intercâmbio de experiências em questões como as condições de trabalho e o mercado editorial nos respectivos países. A intensa convivência entre os participantes propicia o surgimento de novas parcerias e o estreitamento de laços, que levaram a iniciativas como a criação de um fórum na internet, recurso que se tornou um poderoso instrumento de ajuda mútua e troca entre os profissionais, como nos esclarece a alemã Wanda Jakob: "Uma das minhas fontes de apoio é um grupo de tradutores alemães e brasileiros que, depois de uma oficina, estabeleceram um mailing group, que é ótimo para esclarecer dúvidas" (Bruchard et al., 2017, p. 209). A tradutora se refere à oficina vice-versa de 2012, em Paraty, que promoveram em parceria a FBN, a UFF e o Fundo Alemão para Tradução.

As oficinas despertam grande interesse por parte dos tradutores, portanto o número de candidatos costuma ser bastante elevado. No caso de Paraty, os organizadores contaram 27 inscrições para apenas sete vagas, o que os levou a estabelecer os seguintes critérios de avaliação de candidaturas:

(i) qualidade da tradução proposta pelo candidato;

(ii) prioridade para projetos cujos tradutores já tivessem contrato com uma editora;

(iii) busca por variedade de gêneros literários a fim de dar conta dos problemas característicos de diferentes tipos de textos;

(iv) inclusão de candidatos fora do eixo Rio-São Paulo;

(v) participação de pelo menos um tradutor iniciante, isto é, sem nenhuma tradução publicada;

(vi) busca por tradutores com experiências, idades e vivências diversas.

Observa-se nos critérios uma grande preocupação com a diversidade, tanto no que tange a experiência, idade e vivência dos participantes, quanto no que diz respeito aos 
gêneros literários e às épocas, essas últimas preocupações perceptíveis nos quadros de participantes das oficinas de Paraty e Curitiba na página seguinte, nos quais constatamos a diversidade de estilos - uma vez que lá estão contemplados poetas como Carlos Drummond de Andrade e romancistas como Luiz Ruffato -, a variedade de épocas - já que encontramos desde clássicos como Machado de Assis até autores contemporâneos como Rafael Cardoso -, sem nos esquecer da presença de escritoras femininas, como Clarice Lispector, Marina Colasanti e Carola Saavedra. O objetivo de ir além do eixo Rio-São Paulo também foi alcançado, uma vez que há participantes de Curitiba, Salvador, Porto Alegre e Florianópolis. Cabe ainda ressaltar a importância de se reservar vagas para iniciantes, que, na convivência com profissionais experientes, têm a oportunidade de dar um salto qualitativo em pouco tempo.

A oficina de tradução é uma oportunidade ímpar de se concentrar em um projeto durante uma semana e de contar com a valiosa ajuda de colegas das duas línguas. Durante seis dias, alemães e brasileiros, munidos de um projeto de tradução, trabalharam de forma concentrada em três sessões diárias de duas horas, sem contar as sessões dedicadas a temas específicos, a debates ou visitas a editoras. No início de cada sessão, um participante era destacado para moderar os debates e apresentar o tradutor, que, por sua vez, introduzia a obra e suas principais dificuldades. Os demais participantes sugeriam alterações e aperfeiçoamentos no texto. Um outro participante era incumbido de redigir uma ata das reuniões de modo a registrar os principais problemas de tradução entre as duas línguas. Por meio dessa iniciativa, os participantes criaram uma lista de problemas recorrentes, ampliada a cada nova oficina, que se tornou uma valiosa ferramenta de trabalho. Coube aos coordenadores moderar as discussões e estabelecer relações entre os temas discutidos.

Enfim, o objetivo de longo prazo das oficinas é constituir uma rede de cooperação entre tradutores das duas línguas a fim de superar as dificuldades enfrentadas pelo trabalho solitário caraterístico da atividade tradutória, permitindo a troca de experiências, a vivência da cultura, brasileira ou alemã, in loco e o debate não apenas de questões literárias, linguísticas e culturais, mas também das condições de trabalho. 
Quadro 24: Tradutores e obras da oficina de tradução português-alemão e vice-versa de Paraty em 2012.

\begin{tabular}{|c|c|c|}
\hline & Tradutor & Autor e título \\
\hline & Álvaro Bragança (Rio de Janeiro) & Hartmann von Aue, Iwein \\
\hline & Claudia Abeling (São Paulo) & $\begin{array}{l}\text { Herta Müller, Der Fuchs war damals schon der } \\
\text { Jager }\end{array}$ \\
\hline & Daniel Martineschen (Curitiba) & $\begin{array}{l}\text { Johann Wolfgang von Goethe, West-Ostlicher } \\
\text { Diwan }\end{array}$ \\
\hline & Fabiana Naura Macchi (Rio de Janeiro) & Ernst Jandl, Gedichte \\
\hline & Lilian Rau (Salvador) & Ingeborg Bachmann, Horspiele \\
\hline & Luciana Waquil (Porto Alegre) & Jasmin Ramadan, Das Schwein unter den Fischen \\
\hline & Renata Mundt (São Paulo) & $\begin{array}{l}\text { Sabina Spielrein, Überden psychologischen Inhalt } \\
\text { eines Falles von Schizophrenie (Dementia Praecox) }\end{array}$ \\
\hline & Barbara Mesquita (Hamburg) & Patrícia Melo, Ladrão de cadáveres \\
\hline & Luis Ruby (Munique) & Clarice Lispector, O lustre \\
\hline & Maria Hummitzsch (Leipzig) & Carola Saavedra, Paisagem com dromedário \\
\hline 5 & Marianne Gareis (Berlim) & Andréa dei Fuego, Os Malaquias \\
\hline S & Michael Kegler (Hofheim) & Luiz Ruffato. Eles eram muitos cavalos \\
\hline & Peter Kultzen (Berlim) & Rafael Cardoso, Entre as mulheres \\
\hline 5 & Wanda Jakob (Munique) & Carlos Drummond de Andrade, Prosa \\
\hline 8 & Kristina Michahelles (Rio de Janeiro) & Coordenação \\
\hline 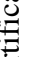 & Johannes Kretschmer (UFF) & Coordenação \\
\hline$\overline{\mathrm{D}}$ & Fabio Lima $(\mathrm{FBN})$ & Coordenação \\
\hline 8 & Carola Saavedra (escritora) & Participação parcial \\
\hline & $\begin{array}{l}\text { Stefanie Kastner (Instituto Goethe - São } \\
\text { Paulo) }\end{array}$ & Participação parcial \\
\hline
\end{tabular}

Fonte: Elaborado pela autora da dissertação (2021)

Quadro 25: Tradutores e obras da oficina de tradução português-alemão e vice-versa de Curitiba em 2014.

\begin{tabular}{|l|l|}
\hline Tradutor & Autor e título \\
\hline Carla Bessa (Berlim) & Max Frisch, Mein Name sei Gantenbein \\
\hline Claudia Abeling (São Paulo) & Alexander von Humboldt, Kosmos \\
\hline Dafne Skarbek (Curitiba) & Marie von Ebner Eschenbach, Krambambuli \\
\hline Daniel Martineschen (Curitiba) & Gerhard Hauptmann, Bahnwarter Thiel \\
\hline Fabiana Macchi (Rio de Janeiro) & Eugen Gomringer, Gedichte \\
\hline Karina Jannini (Sao Paulo) & Joachim Meyerhoff, Wann wird es endlich wieder \\
\hline
\end{tabular}




\begin{tabular}{|l|l|}
\hline & so, wie es nie war \\
\hline Kristina Mlchahelles (Rio de Janeiro) & Stefan Zwelg, Schachnovelle \\
\hline Marcus Tullius (Florianópolis) & Hans Henny Jahnn, Medea \\
\hline Théo Amon (Porto Alegre) & $\begin{array}{l}\text { E.T.A. Hoffmann, Johannes Kreislers, des } \\
\text { Kapellmeisters, musikalische Leiden }\end{array}$ \\
\hline Barbara Bichler (Berlim) & Isabela Figueiredo, Caderno de memórias coloniais \\
\hline Barbara Mesquita (Hamburg) & Pepetela, A gloriosa família \\
\hline Markus Sahr (Leipzig) & Marina Colasanti, Minha guerra alheia \\
\hline Melanie Strasser (Viena) & Machado de Assis, A cartomante \\
\hline Niki Graça (Berlim) & Paulo Henriques Britto e Antônio Moura, Poesia \\
\hline Marianne Gareis (Berlim) & Coordenação \\
\hline
\end{tabular}

Fonte: Elaborado pela autora da dissertação (2021)

4.3.1.2.

Entre-Nós-Otros: oficina de tradução português-espanhol e vice-versa

Entre os dias 11 e 16 de novembro de 2012, a FBN e a UFF promoveram, em Porto Alegre, uma oficina português-espanhol e vice-versa, denominada "Entre-Nós-Otros: Sujeitos Culturais e Miragens Literárias da Tradução Espanhol-Português-Espanhol”, com o intuito de fortalecer o diálogo entre o Brasil e os demais países da América Latina por meio da reflexão e da prática da tradução. O principal objetivo do projeto era criar relações permanentes e intensificar a cooperação entre os tradutores literários da região. Durante o encontro, os profissionais trocaram ideias e discutiram textos nas duas línguas, além de analisar as condições de trabalho e os mercados editoriais. Os critérios utilizados para a seleção de participantes da oficina foram semelhantes aos definidos para as oficinas português-alemão e vice-versa, ou seja, foi priorizada a variedade de gêneros e estilos literários e a participação de tradutores de idades variadas, vivências distintas e níveis de profissionalização diferentes.

Precedendo a oficina, no dia 10 de novembro, os organizadores apresentaram, no âmbito da Feira do Livro de Porto Alegre, a mesa-redonda "Português-Espanhol, Espanhol-Português: Tradução e Literatura". Dela participaram os brasileiros Altair Martins (ficcionista e finalista do Prêmio Jabuti 2009 com o romance A parede no escuro) e Marcelo Barbão (tradutor e editor independente, residente em Buenos Aires), além da mexicana Maria Cristina Hernández Escobar (do Seminário de Tradução 
Literária da Universidad Nacional Autónoma de México). O evento discutiu os diversos aspectos da atividade tradutória no Brasil e nos países de língua espanhola da América em um momento em que o Brasil fora convidado de honra de vários festivais literários no continente, incluindo as feiras do livro de Guadalajara (2001), Santiago do Chile (2007), Lima (2009) e Bogotá (2012), acontecimentos que promoveram um maior intercâmbio cultural e uma divulgação em grande escala da literatura brasileira nos países de língua espanhola.

A oficina, de fato, só teve início no dia 12. Os organizadores do evento, Rodrigo Labriola e Ana Isabel Borges, decidiram dividir os textos entre os dias do evento de modo a agregar estilos e gêneros, planejando sessões dedicadas unicamente a prosa, poesia ou teatro, já que, de acordo com Labriola, "muitos problemas vão se repetir, mas, desse modo, reuniremos questões básicas e poderemos discutir problemáticas diferentes a cada dia" (Entre-Nós-Otros, 2012a). Essa parece ser a forma mais adequada de organização de uma oficina que se propõe a ser diversa, contemplando todos os gêneros de textos.

No dia 12, os três primeiros tradutores a apresentar seu trabalho foram Pablo Cardelino, Marcelo Barbão e Maria Cristina Hernández Escobar. Cardelino traduzia Pitanga, de Carlos Eduardo Magalhães; já Barbão se debruçava sobre Dóberman, obra de realismo fantástico do argentino Gustavo Ferreyra. Por último, Escobar vertia para o espanhol a obra Inferno provisório II: o mundo inimigo, de Luiz Ruffato, segunda incursão da tradutora na obra do autor. Os três tradutores, já bastante experientes, trabalhavam com obras que lançam mão da técnica do fluxo de pensamento, com um estilo, às vezes, muito informal e que nem sempre respeita a pontuação considerada gramaticalmente correta. Cabe destacar também que as três obras estão repletas de referências à história ou à cultura de seus países de origem, o que levou os participantes a discutirem questões como a melhor maneira de lidar com palavras muito características do português ou do espanhol. Também entrou na pauta de discussões o uso de notas de rodapé, consideradas pela maioria dos participantes excessivamente invasivas por desviarem a atenção do leitor. Houve ainda um debate sobre gírias e expressões muito características de uma região ou de um país, dada a diversidade de origens dos falantes do espanhol. Por fim, vale ressaltar que os três tradutores estavam 
trabalhando com autores vivos, com os quais mantinham contato, e reforçaram a importância da comunicação com o escritor para tirar dúvidas sobre certas passagens do texto.

No segundo dia, dedicado a prosa poética, poesia e teatro, quatro profissionais apresentaram suas traduções: as brasileiras Bárbara Pessoa e Flávia Dorneles, o mexicano Rodolfo Mata e o uruguaio Esteban Campanela. Os textos de poesia e prosa poética, por terem características muito específicas, provocaram discussões sobre a possibilidade de manter na tradução aspectos formais, como o ritmo, a métrica, as assonâncias e as aliterações, e aspectos de conteúdo, como as imagens. Já na apresentação do trabalho de Campanela, que traduziu e montou a peça Mi muñequita, do uruguaio Gabriel Calderón, discutiu-se a necessidade de adequar o texto ao público. De acordo com Campanela, foi necessário "adaptar muitas coisas para que o público brasileiro entendesse, como músicas que são referências para os uruguaios, mas que, para os brasileiros, não teriam a mesma força" (Entre-Nós-Otros, 2012b). As adaptações foram tantas que o tradutor chegou a afirmar que "traduzir teatro é quase se transformar em dramaturgo. Ao traduzir, vamos montando uma obra diferente na nossa cabeça" (ibidem).

A manhã do dia 14, uma quarta-feira, que contou com a apresentação das traduções de Guilherme Puccini e Rodrigo Valdés, foi dedicada aos ensaios. Durante a discussão, uma das principais questões a surgir foi a necessidade ou não de simplificar a escrita de ensaístas e acadêmicos, normalmente mais elaborada. Por exemplo, Puccini explicou que, no livro que traduzia - uma transcrição de um curso ministrado pelo filósofo espanhol José Ortega y Gasset -, o autor tentou manter a oralidade, apesar de ser um texto escrito, para que a obra se tornasse mais acessível ao público. No entanto, na opinião do tradutor, "por mais que tente ser acessível, às vezes o texto é um pouco hermético, [...] e eu gosto de manter essas estranhezas, [...] ainda mais com um filósofo poeta, que traz novidades para a escrita" (Entre-Nós-Otros, 2012c). Os participantes da oficina também discutiram a importância das notas de rodapé nos textos acadêmicos, que acreditam exigir do tradutor compartilhar com o leitor os problemas enfrentados ao longo da tradução. O projeto de Valdés também suscitou uma discussão em torno de como devem ser traduzidas as citações que aparecem em textos acadêmicos, ou seja, 
se o tradutor deve buscar traduções já consagradas ou deve traduzi-las ele próprio. Ao final do debate, no entanto, o grupo não conseguiu chegar a um consenso.

Na parte da tarde, de modo a enriquecer o debate sobre a tradução de poesia, os participantes da oficina assistiram a uma mesa-redonda, no Instituto Cervantes, intitulada "O Autor e seu Tradutor". A mesa, também aberta ao público, contou com a participação do mexicano Rodolfo Mata, integrante da oficina, e do poeta paulista Fabio Weintraub, autor do livro Baque - que Mata traduzia para o espanhol. Weintraub abriu a discussão falando sobre sua poesia, que aborda o cotidiano, as desigualdades e as construções sociais exclusivas. Segundo ele, vários poetas já lançaram mão dessa temática, mas uma nova geração começa a trabalhá-la sob outro aspecto. Como exemplo, Fabio usou um dos poemas de Baque, "A Ocasião Faz o Ladrão". Inspirado numa reportagem da Folha de São Paulo, o poema incluiu frases completas da matéria, enunciadas por um delegado de polícia. Mata, que já traduziu Paulo Leminski e Haroldo de Campos para o espanhol, e foi responsável pela publicação de uma antologia de poesia brasileira no México, destacou a importância do ressurgimento de uma poesia brasileira voltada para o cotidiano, antes de tratar especificamente dos desafios da tradução do poema mencionado por Weintraub. Em seguida, o tradutor convocou os colegas de oficina a ajudá-lo a encontrar soluções para algumas das expressões presentes no texto. A discussão se expandiu para toda a plateia, que passou a fazer sugestões para a tradução de outros trechos desafiadores dos poemas de Weintraub.

No dia seguinte, o penúltimo dia da oficina, os participantes assistiram a uma mesa-redonda interna, denominada "Traduções, Culturas e Ficções", com a participação de Johannes Krestchmer e Viviana Gelado, ambos professores da UFF. O objetivo da mesa foi introduzir tópicos teóricos, como a relação entre tradução e cultura, para auxiliar o grupo e enriquecer o intercâmbio de ideias durante o debate da tradução para o português do romance Changó, el gran putas, de Manuel Zapata Olivella, realizada pelo brasileiro Francisco Manhães e apresentada logo após o evento. A obra é um grande épico que cobre 500 anos de história, contada em um estilo definido por Zapata como "realismo mítico". O romance usa a visão de mundo da religião iorubá, e incorpora provérbios, trava-línguas, contos de fadas e canções da tradição 
africana, além de narrar feitos dos heróis negros nas revoluções americanas. Gelado discorreu sobre o surgimento da poesia negrista moderna na América Latina, uma vertente da poesia de vanguarda da qual Zapata fazia parte, e sobre algumas questões que surgem na tradução desse tipo de poesia, muito calcada na oralidade e com grande quantidade de referências culturais. O dia contou ainda com a apresentação dos romances em tradução pela brasileira Renata Pontes e pelo uruguaio Román García Arrospide. O último dia da oficina foi dedicado a uma avaliação dos resultados e às considerações finais dos organizadores.

Quadro 26: Tradutores e obras da oficina de tradução português-espanhol e vice-versa de Porto Alegre em 2012.

\begin{tabular}{|l|l|}
\hline Tradutor & Autor e título da obra \\
\hline Bárbara Pessôa & Oliverio Girondo, Espantapájaros (Al alcance de todos) \\
\hline Esteban Campanela & Gabriel Calderón, Mi muñequita (la farsa) \\
\hline Flávia Dorneles & Diego Chozas, Incumplir los años \\
\hline Francisco Manhães & Manuel Zapata Olivella, Changó, el gran putas \\
\hline Guilherme Puccini & José Ortega y Gasset. El tema de nuestro tiempo \\
\hline Marcelo Barbão & Gustavo Ferreyra, Dóberman \\
\hline Maria Cristina Hernández Escobar & Luiz Ruffato, Inferno provisório II: o mundo inimigo \\
\hline Pablo Cardelino & Carlos Eduardo de Magalhães, Pitanga \\
\hline Renata Pontes & Mário de Andrade, Ensaio sobre a música brasileira \\
\hline Rodolfo Mata & Fabio Weintraub, Baque \\
\hline Rodrigo Valdés & Luiz Costa Lima, Kafka: diante da lei (Limites da voz) \\
\hline Román Garcia Arrospide & Graciliano Ramos, Angústia \\
\hline
\end{tabular}

Fonte: Elaborado pela autora da dissertação (2021)

4.3.1.3.

Escola de Inverno de Tradução Literária: oficina de tradução portuguêsinglês e vice-versa

De 21 a 27 de julho de 2014, antecedendo a Flip, realizou-se em Paraty uma oficina de tradução português-inglês e vice-versa, denominada "Escola de Inverno de Tradução Literária", organizada pela FBN em parceria com as seguintes instituições: 
UFF, British Council (BC), British Center for Literary Translation (BCLT) e Instituto do Patrimônio Histórico e Artístico Nacional (Iphan).

Essa oficina contou com 12 participantes, sendo seis brasileiros e seis estrangeiros. Parece haver um consenso entre os organizadores das oficinas apoiadas pela FBN de que o número ideal de participantes de uma oficina vice-versa gira em torno de 12 a 14 participantes. Além disso, não se pode perder de vista que uma oficina de tradução organizada no Brasil com participantes do próprio país e do exterior acarreta custos elevados que envolvem passagens, hospedagem e alimentação de todos os tradutores, o que contribuiu para que os organizadores se decidissem por um número reduzido de integrantes.

Por ter como objetivo a formação de profissionais de tradução, a oficina definiu como alvo tradutores em início ou meio de carreira que, ao se inscrever, deveriam apresentar um currículo resumido, incluindo a experiência prévia em tradução literária, e um trecho de, no máximo, 4 mil palavras da obra literária escolhida com a respectiva tradução realizada pelo candidato. O tradutor deveria enviar ainda dois textos: um deles contendo as dificuldades de tradução enfrentadas e que gostaria de discutir durante a oficina, e outro refletindo sobre o ofício de tradutor e os benefícios que poderiam advir de sua participação na oficina. Mais uma vez, o número de inscritos superou em muito as expectativas, uma vez que, para um total de apenas 12 vagas, houve 172 inscritos, sendo 125 candidatos para o par inglês-português e 47 para o par português-inglês. A diferença entre o número de candidatos do par inglês-português e do português-inglês reflete mais uma vez a centralidade da língua inglesa, muito traduzida, e reforça a percepção do português como uma língua periférica e pouco traduzida (Sapiro, 2014, p. 85). A seleção levou em consideração a qualidade das traduções apresentadas, a maturidade das reflexões sobre o ofício do tradutor, a variedade de gêneros e estilos contemplados nos textos apresentados e, como critério de desempate, a diversidade geográfica dos tradutores, buscando a promoção do intercâmbio entre profissionais de diversas regiões.

Nas oficinas organizadas pela FBN e seus parceiros, as atividades costumam incluir sessões conjuntas de discussão dos projetos de tradução de todos os participantes, nas quais cada tradutor apresenta trechos considerados problemáticos de 
sua tradução em curso. Além das sessões de discussão, as oficinas costumam incluir encontros e mesas-redondas com tradutores experientes e outros profissionais do mercado editorial para que, além de discutir problemas específicos da tradução, sejam abordadas questões que envolvem também outros profissionais do meio editorial. No entanto, nesta Escola de Inverno, um projeto conjunto de várias instituições, foram introduzidas duas novidades em relação às oficinas anteriores, uma vez que o BCLT faz uso de um modelo próprio de oficina. A primeira inovação foi a divisão dos tradutores em dois grupos conforme a língua para a qual traduziam: um grupo composto por tradutores do português para o inglês (PT $>$ EN), e outro com aqueles cuja língua-alvo era o português $(\mathrm{EN}>\mathrm{PT})$. Esses dois grupos trabalharam separadamente na parte da manhã em um projeto específico de tradução para a sua língua de chegada, e, à tarde, para estimular a integração, todos se reuniam para discutir os próprios projetos de tradução. O segundo diferencial dessa oficina foi a participação, nas atividades da manhã, de um escritor de cada língua, que apresentaria uma obra sua para discussão de trechos pelo grupo de tradutores sob orientação do tradutor experiente convidado a coordenar a atividade. O grupo PT $>$ EN foi coordenado por Daniel Hahn - tradutor de literatura brasileira e latino-americana, além de especialista em literatura infantil - e contou com a presença de José Luiz Passos - escritor brasileiro radicado nos Estados Unidos, onde leciona literatura brasileira na Universidade da Califórnia em Los Angeles, e autor, dentre outras obras, de O sonâmbulo amador (2012), vencedor do Grande Prêmio Portugal Telecom de Literatura de 2013 e do Prêmio Brasília de Literatura em 2014. Já o grupo EN>PT foi coordenado por Paulo Henriques Britto - professor da PUC-Rio tradutor brasileiro de literaturas de língua inglesa, além de poeta, agraciado por duas vezes com o Prêmio Alphonsus de Guimarães, da FBN, e com o Grande Prêmio Portugal Telecom de Literatura de 2003 - e teve a participação do escritor britânico Sam Byers - cujo primeiro romance, Idiopathy, traduzido e publicado no Brasil em 2014, recebeu os prêmios Betty Trask e Waterstones.

Ao longo da oficina, na parte da manhã, o grupo PT $>$ EN traduziu dois trechos de um romance de José Luiz Passos: Um álbum para Lady Laet. Após a apresentação de Passos, Daniel Hahn passou a liderar a tradução de trechos da obra em conjunto com os demais tradutores. Esse grupo contou com a participação das tradutoras e editoras 
Alison Entrekin e Sophie Lewis, que contribuíram para o debate apresentando uma visão editorial do processo de tradução.

Enquanto isso, o grupo EN>PT traduzia o capítulo inicial de um romance de Sam Byers, intitulado Phantom Alerts. O trabalho teve início com uma explanação de Byers sobre o contexto e o tema do romance, e gerou uma discussão sobre a linguagem do texto, repleto de marcas de oralidade, expressões coloquiais e jargões da área de tecnologia da informação, além de um humor peculiar e de uma prosa de ritmo rápido e tom informal. A tradução, liderada por Paulo Henriques Britto, foi construída de forma colaborativa por todos os tradutores e entremeada por interações com o autor. Esse grupo também contou com a contribuição do tradutor e editor Cide Piquet, que abordou questões de tradução do ponto de vista editorial, como as convenções de pontuação em diálogos.

Com exceção do último dia, todas as tardes da semana da oficina foram destinadas à discussão do trabalho individual de cada tradutor participante. Essas atividades vespertinas foram coordenadas por Carolina Paganine e Giovana Cordeiro Campos de Mello, professoras de tradução da UFF, e contaram com a presença de estudiosos e tradutores convidados, como o próprio Paulo Henriques Britto, além de Lawrence Flores Pereira, Susana Kampff Lages, Allison Entrekin, Lenita Rimoli Esteves, para citar apenas alguns nomes.

Quadro 27: Tradutores e obras da oficina de tradução português-inglês e vice-versa de Paraty em 2014.

\begin{tabular}{|l|l|}
\hline Tradutor & Autor e título da obra \\
\hline Alexandre Hubner & Vladmir Nabokov, Pnin \\
\hline Amarílis Anchieta & Chinua Achebe, Civil Peace \\
\hline Ana Fletcher & Campos de Carvalho, O púcaro búlgaro \\
\hline Annie McDermott & Antônio Fraga, O louva-deus \\
\hline Caetano Galindo & James Joyce, A Portrait of the Artist as a Young Man \\
\hline Felipe Vidal & Martin Krimp, In the Republic of Happiness \\
\hline Jethro Soutar & Vinicius Jatobá, E ainda era no tempo do rei \\
\hline Juliana Steil Tenfen & William Blake, Milton, a poem \\
\hline Lucy Greaves & Elvira Vigna, O que deu para fazer em matéria de história de amor \\
\hline Natália Klussman & Edward St. Aubyn, Mother's Milk \\
\hline Rahul Bery & Daniel Pellizzari, Digam a Satã que o recado foi entendido \\
\hline
\end{tabular}




\begin{tabular}{|l|l|}
\hline Zoë Perry & Ana Paula Maia, De gados e homens \\
\hline Daniel Hahn (BCLT) & Coordenação \\
\hline Paulo Henriques Britto & Coordenação \\
\hline Caroline Paganine (UFF) & Coordenação \\
\hline Giovana Campos (UFF) & Coordenação \\
\hline
\end{tabular}

Fonte: Elaborado pela autora da dissertação (2021) 
5.

\section{Considerações finais}

Este estudo teve como objetivo examinar o papel das iniciativas da FBN de internacionalização da literatura brasileira por meio de ações voltadas para favorecer a circulação de nossos autores e obras nos diversos centros literários mundiais. Depois da apresentação e da análise do projeto colocado em prática pela FBN, bem como de um exame da evolução e dos resultados obtidos por tal iniciativa, concluo que os esforços feitos pela instituição no sentido de unir, de um lado, os agentes culturais envolvidos na cena editorial brasileira, como autores, editores e agentes literários que atuam no Brasil e, de outro lado, os editores e agentes literários estrangeiros, bem como os tradutores da língua portuguesa, tem surtido efeitos positivos, ampliando as oportunidades disponíveis aos agentes culturais estrangeiros interessados em promover

a circulação de nossa literatura no exterior. Corroboram o êxito das ações de patronagem da FBN os resultados animadores obtidos pelos programas da instituição, como o alentado número de candidatos a bolsas da instituição, o grande número de autores interessados em figurar nas publicações da entidade, que visam a promover obras e autores da literatura brasileira no exterior, o interesse suscitado pelo Programa de Residência de Tradutores Estrangeiros no Brasil e pelo Programa de Intercâmbio de Autores Brasileiros no Exterior, e a procura pelas oficinas de tradução promovidas pela instituição.

O exame das iniciativas da FBN permite concluir que a promoção da literatura brasileira por meio da participação da instituição em feiras literárias internacionais é uma aposta na qual o Brasil vem investindo há muitos anos, até como homenageado, e que tem gerado frutos importantes, como um grande aumento no número de traduções e publicações de obras da literatura brasileira a cada nova homenagem prestada ao país por uma grande feira literária. Complementando o trabalho já desenvolvido há tempos durante as feiras, cuja representação brasileira sempre inclui vários autores da literatura nacional, a FBN criou o Programa de Intercâmbio de Autores Brasileiros no Exterior, que incentiva agentes culturais estrangeiros a convidarem autores brasileiros para participar de eventos literários internacionais, atendendo à demanda dos editores 
estrangeiros por autores contemporâneos capazes de falar sobre si, sobre sua obra e sobre o que representa ser um escritor no Brasil. No entanto, esse programa poderia ser aperfeiçoado com o subsídio da FBN à contratação de intérpretes dos autores contemplados com as bolsas, uma vez que, em sua maioria, os escritores não falam a língua do país em que são homenageados.

Concluí também que editores e agentes que abordam o polissistema literário brasileiro em busca de títulos para tradução contam tradicionalmente com referências sobre a produção literária originadas nos meios acadêmicos, representados por professores dos departamentos de língua portuguesa das instituições de ensino estrangeiras, e nos meios editoriais, expressos por tradutores da língua portuguesa e agentes literários, que costumam indicar aos editores os autores nos quais consideram interessante apostar. Com as antologias da FBN voltadas para o mercado externo, os agentes editoriais estrangeiros interessados na nossa literatura passaram a contar também com a orientação de profissionais dos campos acadêmico, literário e editorial brasileiros que compõem os conselhos editoriais das publicações, e que se tornaram corresponsáveis pela formação de cânones da nossa literatura no exterior. Como as obras e autores publicados no exterior com a patronagem da FBN sofrem grande influência do polissistema literário doméstico, por meio, por exemplo, de iniciativas como a elaboração de guias, catálogos e revistas, para entender os fenômenos observados no exterior foi necessário considerar a posição no sistema literário de origem ocupada por cada um dos autores e das obras beneficiadas.

Além disso, nossos prêmios literários têm desempenhado importante papel na divulgação da obra de autores contemporâneos, principalmente em território nacional, como no caso do conjunto de prêmios da FBN, mas também com reflexos no mercado internacional, como no caso da categoria "Livro Brasileiro Publicado no Exterior" do Prêmio Jabuti, mais uma forma de estimular editores estrangeiros a se interessar pelo livro brasileiro e de dar visibilidade a nossos prêmios literários no exterior.

Em relação, especificamente, ao programa de bolsas de tradução, vale destacar que, a partir de uma análise detalhada do histórico de distribuição das bolsas da instituição por autor e país, comprovei: (i) a existência de dois momentos do programa, sendo que o primeiro, que abrange o período de 1991 a 2009, ofereceu um número bem 
reduzido, quase simbólico, de bolsas, enquanto que o segundo, de 2010 em diante, constitui-se em uma força capaz de influenciar as decisões de publicação de traduções das casas editoriais estrangeiras; (ii) uma seleção de autores e obras a serem contemplados com as bolsas com a preocupação de dar maior atenção ao polo literário estético, sem, no entanto, deixar de lado os autores identificados com o polo comercial, que ainda precisam de ajuda para penetrar em certos centros periféricos, como a China; (iii) o interesse do projeto em promover a diversidade no que diz respeito à multiplicidade de obras contempladas com as bolsas e de línguas para as quais as obras da literatura brasileira são traduzidas, mas não a diversidade de autores, uma vez que mulheres e minorias encontram-se sub-representadas; e (iv) a influência das culturas hegemônicas (perceptível no quadro do número de bolsas por país) na definição do que será traduzido e, consequentemente, lido não só nos principais centros literários, mas também nas regiões periféricas.

Quanto à penetração da literatura brasileira no exterior entre o público leitor, concluo que, mesmo com todos os esforços realizados pela FBN e por outros agentes de patronagem, no momento, temos um único autor popular no estrangeiro: Paulo Coelho. Outros autores brasileiros, como Machado de Assis, Jorge Amado e Clarice Lispector, embora frequentem o cânone no Brasil, gozem de muito prestígio no exterior e contem com patronos dedicados, não são conhecidos do grande público. No entanto, cabe reforçar que uma das últimas traduções de Memórias póstumas de Brás Cubas, vertida para o inglês por Flora Thomson-Deveaux, se esgotou nos sites da Amazon e da livraria Barnes \& Noble em um dia, sendo a obra de literatura latino-americana mais vendida nos EUA no momento. Contribuíram para esse resultado as diversas recomendações de críticos e autores que não pouparam elogios a Machado (Vaiano, 2020, s,p.), o que comprova o grande número de patronos envolvidos na promoção das obras do autor em língua inglesa. Portanto, embora não se possa dizer desses autores que são populares, pode-se afirmar, no entanto, que eles fazem parte do patrimônio literário mundial, lembrando, por exemplo, que Machado de Assis foi citado por Harold Bloom em sua obra Gênio (2003) como um dos 100 autores da literatura universal que valem a pena ser lidos. Por sua vez. os autores contemporâneos parecem despertar grande interesse por parte dos editores estrangeiros, uma vez que, na opinião, por 
exemplo, da editora francesa Anne-Marie Métailié, “o livro praticamente existe só se o escritor pode falar, pode se mostrar" (Itaú Cultural, 2008, s.p. apud Pardo, 2010, p. 122), referindo-se às preferências do mercado francês em relação a textos de autores brasileiros jovens. Essa busca por novidades levou à publicação de várias antologias de jovens autores ainda inéditos no exterior. No entanto, pouco se pode afirmar sobre esses autores até o momento, uma vez que estes não tiveram tempo nem de conquistar os mercados estrangeiros nem de se tornar clássicos da literatura universal.

Não podemos esquecer a colaboração que o projeto da FBN tem oferecido no sentido de formar ou aperfeiçoar novos tradutores da língua portuguesa por meio de iniciativas como o Programa de Residência de Tradutores Estrangeiros no Brasil e as oficinas de tradução realizadas em parceria com outras instituições. O programa e as oficinas têm por objetivo preparar profissionais de tradução nas línguas hegemônicas, a saber, inglês, francês, espanhol e alemão, cujas traduções de obras da literatura brasileira servirão não apenas para a divulgação da nossa literatura nos principais centros literários do mundo, mas também para sua difusão em centros literários periféricos por meio de traduções.

As análises aqui empreendidas comprovam a importância das iniciativas do governo federal, ao lado de ações de outros agentes de patronagem, para atrair mais atenção para a literatura produzida no Brasil, e os dados sugerem que nosso país tem caminhado em direção a um maior reconhecimento internacional de seus escritores e de sua literatura. No entanto, é importante ressaltar que os dados nos quais se baseiam as análises aqui realizadas, embora bastante significativos e capazes de nos revelar pistas sobre as relações que se estabelecem entre línguas de partida e de chegada, bem como sobre a dinâmica literária mundial, por dizerem respeito, principalmente, ao conjunto de iniciativas de internacionalização da literatura brasileira da FBN, não podem ser considerados representativos do cenário literário e editorial como um todo. Há diversos outros agentes culturais envolvidos nas trocas literárias internacionais, portanto, a análise aqui elaborada visa tão somente identificar as contribuições da instituição para a circulação da literatura brasileira no exterior, sem deixar de reconhecer a importância de se elaborar um exame de todos os outros agentes envolvidos nesse processo para que se tenha uma visão por inteiro da participação da 
nossa literatura no cenário literário mundial. De qualquer forma, os resultados encontrados comprovam a importância de se investir em iniciativas governamentais de disseminação e de internacionalização da literatura brasileira, seja por meio da concessão de bolsas de apoio ou da inserção do país nas agendas culturais internacionais, de modo a conquistar para o Brasil uma posição mais central no espaço de trocas literárias internacionais.

Por fim, cabe destacar dois pontos importantes para o êxito do projeto da FBN: (i) as iniciativas colocadas em prática pela instituição precisam de continuidade, observação oportuna em um momento em que já se contam cinco anos desde a publicação do último edital do Programa de Residência de Tradutores Estrangeiros no Brasil e do Programa de Intercâmbio de Autores Brasileiros no Exterior; e (ii) a instituição precisa intensificar seu trabalho no sentido de incentivar um maior número de traduções de poesia, teatro e ensaio, gêneros pouco contemplados com bolsas ou nem sempre lembrados nas publicações voltadas para a promoção de nossa literatura junto ao mercado editorial estrangeiro. 


\section{Referências bibliográficas}

BAKER, Mona. Linguística e Estudos Culturais. In: MARTINS, Marcia A. P. (Org.). Tradução e multidisciplinaridade. Rio de Janeiro: Lucerna, 1999. p. 15-31.

BASSNETT, Susan; LEVEFERE, Andre. General editor's preface. Translation, rewriting and the manipulation of literary fame. New York: Routledge, 1992.

BASTIDE, Roger. Machado de Assis, paisagista. Teresa: Revista de Literatura Brasileira, n. 6-7, 2005 [1940], p. 418-428. Disponível em: <https://www.revistas.usp.br/teresa/article/view/116634>. Acesso em: 5 nov. 2020.

BASTOS, Jorge Henrique. Prêmio Camões: as vias e as vidas de um prêmio. Revista Camões, n. 11, 2000. Disponível em: <http://cvc.institutocamoes.pt/conhecer/biblioteca-digital-camoes/revistas-e-periodicos/revistacamoes/revista-no11-pontes-lusofonas-iii.html>. Acesso em: 4 jan. 2021.

BELLOTTO. Tony (Org.). Rio Noir. Rio de Janeiro: Casa da Palavra, 2014. Edição Kindle.

BENNETT, Andrew; ROYLE, Nicholas. Introduction to Literature, Criticism and Theory. 3. ed. London: Pearson Longman, 2004.

BIBLIOTECA NACIONAL (Brasil). Prêmio Camões de Literatura. Disponível em: <https://www.bn.gov.br/explore/premios-literarios/premio-camoes-literatura>. Acesso em: 22 dez. 2020.

BIBLIOTECA NACIONAL. Prêmio Literário Biblioteca Nacional. Disponível em: <https://www.bn.gov.br/explore/premios-literarios/premio-literario-bibliotecanacional>. Acesso em: $22 \mathrm{dez} .2020$.

BLOOM, Harold. Gênio: os $\mathbf{1 0 0}$ autores mais criativos da história da literatura. José Roberto O'Shea (Trad.). Rio de Janeiro: Objetiva, 2003. Disponível em: <https://www.academia.edu/38480887/100_Autores_Mais_Criativos_Da_Historia_D a_Literatura_Harold_Bloom_rtf_Os_Harold_Bloom_pdf>. Acesso em: 27 out. 2020.

O cânone ocidental: os grandes livros e os escritores essenciais de todos os tempos. Tradução Manuel Frias Martins. Lisboa: Temas e Debates; Círculo de Leitores, 2013.

BRUCHARD et al. (Org.). Os lugares da tradução. Rio de Janeiro: Fundação Biblioteca Nacional; Niterói, RJ: UFF, Instituto de Letras, 2017.

CANDIDO, Antonio. Esquema Machado de Assis. Disponível em: <http://paginapessoal.utfpr.edu.br/mhlima/Esquema_Machado_de_Assis.pdf/view〉. Acesso em: 14 abr. 2021. 
CASANOVA, Pascale. A república mundial das letras. Tradução Marina Appenzeller. São Paulo: Estação Liberdade, 2002.

Consecration and Accumulation of Literary Capital: Translation as Unequal Exchange. Translation by Siobhan Brownlie. In: BAKER, Mona (ed.). Critical Readings in Translation Studies. London \& New York: Routledge, 2010. p. 285-303.

CONEXÕES Itaú Cultural. Banco de dados. Disponível em: <https://conexoesitaucultural.org.br/banco-de-dados/>. Acesso em: 19 ago. 2020.

DANTAS, Marta Pragana. O que podem as traduções pela literatura brasileira? Belas Infiéis. v. 6, n. 2, p. 11-20, 2017.

- A circulação da literatura brasileira no século XXI: tradução e mercado editorial. Revista Letras Raras. Campina Grande, Edição Especial, p. Port. 153-165 / Eng. 159-171, nov. 2019.

DARIN, Leila. A mediação crítica do tradutor e do intérprete em contextos interculturais. Tradução \& Comunicação. v. 15, 2006. Disponível em: <https://seer.pgsskroton.com/index.php/traducom>. Acesso em: 03 set. 2020.

ENTRE-NÓS-OTROS: veja como foi o primeiro dia da oficina. 13 nov. 2012a. Disponível em: <https://bookcenterbrazil.wordpress.com/2012/11/13/entrenosotrosveja-como-foi-o-primeiro-dia-de-oficina/>. Acesso em: 18 set. 2020.

ENTRE-NÓS-OTROS: confira como foi o segundo dia. 19 nov. 2012b. Disponível em: <https://bookcenterbrazil.wordpress.com/2012/11/19/entrenosotros-confira-como-foio-segundo-dia-de-oficina/>. Acesso em: 18 set. 2020.

ENTRE-NÓS-OTROS: veja como foi o terceiro dia. 19 nov. 2012c. Disponível em: $<$ https://bookcenterbrazil.wordpress.com/2012/11/19/oficina-entrenosotros-vejacomo-foi-o-terceiro-dia/>. Acesso em: 21 set. 2020.

ENTRE-NÓS-OTROS: mesa Traduções, Culturas e Ficções. 27 nov. 2012d. Disponível em <https://bookcenterbrazil.wordpress.com/2012/11/27/entrenosotrosmesa-traducoes-culturas-e-ficcoes/>. Acesso em: 21 set. 2020.

ESPOSITO, Scott. Passionate Acolytes: An Interview with Benjamin Moser. The Paris Review, 17 ago. 2015. Disponível em: <http://www.theparisreview.org/blog/2015/08/17/passionate-acolytes-an-interviewwith-benjamin-moser/>. Acesso em: 12 nov. 2020.

ESTEVES, Lenita Maria Rimoli. A presença da literatura brasileira no exterior e a importância do agenciamento: uma análise guiada por conceitos da sociologia de Pierre Bourdieu. O Eixo e a Roda. Belo Horizonte, v. 25, n. 1, p. 9-36, 2016. 
- Uma discussão sobre a prática da retradução com base no caso das republicações de obras de Clarice Lispector no exterior. Trabalhos em Linguística Aplicada, Campinas, n(55.3), p. 651-676, set./dez. 2016.

EVEN-ZOHAR, Itamar. (1990a) Polysystem Theory. In: Polysystem Studies, Poetics Today (11:1, p. 9-26). Disponível em: <https://m.tau.ac.il/ itamarez/works/books/Even-Zohar_1990-Polysystem\%20studies.pdf $>$. Acesso em: 17 jun. 2019.

. (1990b) The Position of Translated Literature within the Literary Polysystem. In: Polysystem Studies, Poetics Today (11:1, p. 45-51). Disponível em: <https://m.tau.ac.il/ itamarez/works/books/Even-Zohar_1990-Polysystem\%20studies.pdf>. Acesso em: 17 jun. 2019.

FERES, Lilia Baranski; BRISOLARA, Valéria Silveira. A literatura brasileira em tradução: o Programa de Apoio à Tradução e à Publicação de Autores Brasileiros no Exterior como ferramenta de interferência no polissistema literário. Revista da Anpoll. v. $1, \mathrm{n}^{\mathrm{o}}$ 44, p. 331-345, Florianópolis, Jan./Abr. 2018. Disponível em: <https://revistadaanpoll.emnuvens.com.br/revista/article/view/1157>.Acesso em: 17 jul. 2018.

Tradução: uma ação política de reforço da identidade nacional.

Linguagem em Foco. Revista do Programa de Pós-Graduação em Linguística Aplicada da UECE. V. 7, N. 1, ano 2015. Disponível em:

<https://revistas.uece.br/index.php/linguagememfoco/article/view/1683>. Acesso em: 17 jul. 2018.

FUNDAÇÃO INSTITUTO DE PESQUISAS ECONÔMICAS. Produção e Vendas do Setor Editorial Brasileiro - Ano Base 2018. Disponível em: <https://snel.org.br/wp/wpcontent/uploads/2019/04/Apresentacao_pesquisa_ano_base_2018_imprensa.pdf>.

Acesso em: 24 nov. 2019.

G1. Chico Buarque diz que Bolsonaro não assinar diploma é "um segundo prêmio Camões". 9 out. 2019. Disponível em: <https://g1.globo.com/poparte/musica/noticia/2019/10/09/chico-buarque-diz-que-bolsonaro-nao-assinardiploma-e-um-segundo-premio-camoes.ghtml>. Acesso em: 5 jan. 2021.

GALINDO, Caetano. Em tradução (tradutores). Blog da Companhia. Disponível em <http://www.blogdacompanhia.com.br/2014/08/em-traducao-tradutores/>. Acesso em: 28 set. 2020 .

GOMES, Maria Lucia Santos Daflon. Identidades refletidas: um estudo sobre a imagem da literatura brasileira construída por tradução. 2005. 166 f. Dissertação (Mestrado em Estudos da Linguagem) - Pontifícia Universidade Católica do Rio de Janeiro, Rio de Janeiro: 2005. 
GRIFFIN, N. (1996). Obituary: Giovanni Pontiero. Independent, 10 mar. Disponível em: <http://www.independent.co.uk/news/people/obituary-giovanni-pontiero1341546.html>. Acesso em: 13 nov. 2020.

GUEDES, Diogo. Jorge Amado segundo a crítica literária. JC. 4 ago. 2012. Disponível em: <https://jc.ne10.uol.com.br/canal/cultura/literatura/noticia/2012/08/04/jorgeamado-segundo-a-critica-literaria-51532.php>. Acesso em: 23 nov. 2020.

HEILBRON, Johan; SAPIRO, Gisèle. Outline for a Sociology of Translation. In: WOLF, Michaela; FUKARI, Alexandra (Eds.) Constructing a Sociology of Translation. New York/Amsterdam: John Benjamins, 2007. p. 93-105.

; __ Por uma sociologia da tradução: balanço e perspectivas. Tradução de Marta Pragana Dantas e Adriana Cláudia de Sousa Costa. Graphos. João Pessoa, vol. 11, n. 2, dez. 2009.

HEILBRON, Johan. Towards a Sociology of Translation: Book Translations as a Cultural World System. In: BAKER, Mona (Ed.). Critical Readings in Translation Studies. London; New York: Routledge, 2010.

HERMANS, Theo. Translation Studies and a new paradigm. In: HERMANS, Theo (Ed.). The Manipulation of Literature: studies in literary translation. London: Croom Helm, 1985. p. 7-15.

IHU ONLINE. Clarice Lispector: uma vida contada pela palavra escrita. Ed. 228. 16 jul. 2007. Disponível em: <http://www.ihuonline.unisinos.br/artigo/1134-dadosbiograficos>. Acesso em: 12 nov. 2020.

INDEX TRANSLATIONUM. "TOP 50" Country. Disponível em: $<$ http://www.unesco.org/xtrans/bsstatexp.aspx?crit1L=1\&nTyp=min\&topN=50>. Acesso em: 21 jun. 2019.

JORNAL DO BRASIL. Prêmio Camões gera polêmica. Rio de Janeiro, ano 1993, edição 90, Caderno $\mathrm{B}, \quad$ p. $7 . \quad$ Disponível em: <http://memoria.bn.br/DocReader/DocReader.aspx?bib=030015_11\&pesq=\%22Pr\% C3\%AAmio \%20Cam\%C3\%B5es\%20gera\%20pol\%C3\%AAmica\%22\&pagfis=9323 1>. Acesso em: 5 jan. 2021.

LEFEVERE, André. Translation, rewriting and the manipulation of literary fame. New York: Routledge, 1992.

LIMA, Fabio; SALGADO, Moema. Entrevista concedida a Agnes Rissardo e Ieda Magri. A literatura brasileira no exterior: Moema Salgado e Fábio Lima (FBN). Z Cultural. Revista do Programa Avançado de Cultura Contemporânea. 2015. Disponível em: $<$ https://www.academia.edu/26911309/A_literatura_brasileira_no_exterior_entrevista _com_Moema_Salgado_e_F\%C3\%A1bio_Lima_FBN_>. Acesso em: 30 jun. 2019. 
LIMA, Fabio. Publicação eletrônica [mensagem pessoal]. Mensagem recebida em 23 jun. 2020.

LISTA de ganhadores do Prêmio Jabuti. In: Wikipédia. Disponível em: <https://pt.wikipedia.org/wiki/Lista_de_ganhadores_do_Pr\%C3\%AAmio_Jabuti\#Liv ro_Brasileiro_Publicado_no_Exterior>.Acesso em: 22 dez. 2020.

LISTA de prêmios literários. In: Wikipédia. Disponível em: <https://pt.wikipedia.org/wiki/Lista_de_pr\%C3\%A9mios_liter\%C3\%A1rios>. Acesso em: 22 dez. 2020.

LITRO. Rio. n. 114 n $2012 . \quad$ Disponível em: <https://www.litromagazine.com/magazine/litro-114-brazil-rio/>. Acesso em: 9 dez. 2020.

LITRO. The Women's Writing Issue. n. 129, 2013. Disponível em: <https://www.litromagazine.com/magazine/litro-129-brazil/>. Acesso em: $9 \mathrm{dez}$. 2020.

MACHADO DE ASSIS MAGAZINE: Brazilian Literature in Translation. São Paulo, n.1, 2012. Disponível em: <https://www.bn.gov.br/producao/publicacoes/revistamachado-assis-numero-01>. Acesso em: 12 jan. 2021.

MACHADO DE ASSIS MAGAZINE: Brazilian Literature in Translation. São Paulo, n.2, 2013. Disponível em: <https://www.bn.gov.br/producao/publicacoes/revistamachado-assis-numero-02>. Acesso em: 12 jan. 2021.

MACHADO DE ASSIS MAGAZINE: Brazilian Literature in Translation. São Paulo, n.3, 2013. Disponível em: <https://www.bn.gov.br/producao/publicacoes/revistamachado-assis-numero-03>. Acesso em: 12 jan. 2021.

MACHADO DE ASSIS MAGAZINE: Brazilian Literature in Translation. São Paulo, n.4, 2013. Disponível em: <https://www.bn.gov.br/producao/publicacoes/revistamachado-assis-numero-04>. Acesso em: 12 jan. 2021.

MACHADO DE ASSIS MAGAZINE: Brazilian Literature in Translation. São Paulo, n.5, 2013. Disponível em: <https://www.bn.gov.br/producao/publicacoes/revistamachado-assis-numero-05>. Acesso em: 12 jan. 2021.

MACHADO DE ASSIS MAGAZINE: Brazilian Literature in Translation. São Paulo, n.6, 2015. Disponível em: <https://www.bn.gov.br/producao/publicacoes/revistamachado-assis-numero-06>. Acesso em: 12 jan. 2021.

MACHADO DE ASSIS MAGAZINE: Brazilian Literature in Translation. São Paulo, n.7, 2015. Disponível em: <https://www.bn.gov.br/producao/publicacoes/revistamachado-assis-numero-07>. Acesso em: 12 jan. 2021. 
MAGNO, Joanna Ivete Duna. Brazilian Authors Translated Abroad. Rio de Janeiro: Fundação Biblioteca Nacional, 1994.

MAIA. Maria Carolina. Record deixa Jabuti alegando escolha política na premiação. Veja, 12 nov. 2010. Disponível em: <https://veja.abril.com.br/cultura/record-deixajabuti-alegando-escolha-politica-na-premiacao/>. Acesso em: 22 dez. 2020.

MARQUES, Toni (Org.). The Book of Rio: A City in Short Fiction. Manchester: Comma Press, 2014. Edição Kindle.

MARTINS, Marcia A. P. O papel da patronagem na difusão da literatura brasileira: o programa de apoio à tradução da Biblioteca Nacional. In: GUERINI, Andréia; TORRES, Marie-Hélène C.; COSTA, Walter Carlos (Org.). Literatura traduzida e literatura nacional. Rio de Janeiro: 7Letras, 2008.

MAURA, Antonio. Brasil, terra de erotismo, luz e vida (Jorge Amado na Espanha). Amerika. out. 2014. Disponível em: 〈https://journals.openedition.org/amerika/4981〉. Acesso em: 24 nov. 2020.

MILAN, Betty. O tradutor de Marquez e Machado. +Mais, 15 mar. 1998. Disponível em: <https://www1.folha.uol.com.br/fsp/mais/fs15039812.htm>. Acesso em: $1 \mathrm{dez}$. 2020 .

MIROIR. Jean-Claude Lucien. Clarice Lispector e seus Tradutores: da Fúria à Melodia. O Eixo e a Roda. Belo Horizonte, v.25, n.1, p. 61-85, 2016. Disponível em: <http://www.periodicos.letras.ufmg.br/index.php/o_eixo_ea_roda/article/viewFile/10 183/9669>. Acesso em: 12 nov. 2020.

MOREIRA, Paulo. O lugar de Machado de Assis na República Mundial das Letras. Revista Machado de Assis em Linha, ano 2, n. 4, p. 96-107, dez. 2009. Disponível em: <http://machadodeassis.net/download/numero04/num04artigo05.pdf >. Acesso em: 28 out. 2020 .

MOSER, Benjamin. Benjamin Moser: "Clarice Lispector e eu deciframos um ao outro". Revista Época, 17 maio 2016. Disponível em: $<$ https://epoca.globo.com/vida/noticia/2016/05/benjamin-moser-clarice-lispector-eeu-deciframos-um-ao-outro.html >. Acesso em: 10 nov. 2020.

NEW LONDON LIBRARIUM. Home. Disponível em: <https://nllibrarium.com/home.html>. Acesso em: 30 out. 2020.

OLIVEIRA. Nelson de. Contrabandistas da rua de mão única. Verdades provisórias: anseios crípticos. São Paulo: Escrituras Editora, 2003.

PARDO, Carmem Villarino. Mercados para a literatura brasileira. Lugares da lusofonia. Lisboa: Edições Colibri, 2010. Disponível em: 
<https://www.academia.edu/6232478/Mercados_para_a_literatura_brasileira_2010_? auto=download\&email_work_card=download-paper>. Acesso em: 20 jan. 2021.

PENJON, Jacqueline. Machado de Assis: um século de traduções francesas. e-Letras com Vida, n. 2, jan-jun 2019, p. 188-201. Disponível em: <http://elcv.online/index.php/revista/issue/view/2>. Acesso em: 2 nov. 2020.

PEREIRA, Maria Marta Laus. Aspectos da recepção de Clarice Lispector na França. Anuário de Literatura, n. 3, 1995, pp. 109-125. Disponível em: <https://periodicos.ufsc.br/index.php/literatura/article/view/5282/4783>. Acesso em: 10 nov. 2020.

PLATAFORMA RICHARD BURTON: base de dados sobre literatura brasileira em tradução. Disponível em: $<$ http://richardburton.canoas.ifrs.edu.br:8080/faces/search.xhtml;jsessionid=8UV-izxL0F_fEdJoJJRHxxQ5xC6D_KalXNKog4i.unknown-host>. Acesso em: 27 out. 2020 .

PRÊMIO CAMÕES. In: Wikipédia. Disponível em: <https://pt.wikipedia.org/wiki/Pr\%C3\%A9mio_Cam\%C3\%B5es>. Aceso em: 22 dez. 2020.

PRÊMIO JABUTI. Categoria Livro Brasileiro Publicado no Exterior. Disponível em: <https://www.premiojabuti.com.br/anexo-ii_livro-brasileiro-publicado-no-exterior2020.pdf>. Acesso em: 22 dez. 2020.

PRÊMIO JABUTI. História. Disponível em: <https://www.premiojabuti.com.br/historia/>. Acesso em 22 dez. 2020.

PRÊMIO JABUTI. Regulamento - Prêmio Jabuti 2020. Disponível em: <https://www.premiojabuti.com.br/regulamento-premio-jabuti-2020_atualizado.pdf>. Acesso em: 22 dez. 2020.

REIS, Roberto. Cânon. In: JOBIM, J. L. (Org.). Palavras da Crítica. Rio de Janeiro: Imago, 1992. p. 65-9.

RIVAS, Pierre. Diálogos Interculturais. São Paulo: Hucitec, 2005.

SALES, Kall Lwys Barroso; TORRES, Marie-Hélène Catherine. Adrien Delpech. 2018. Dicionário de tradutores literários no Brasil. Disponível em: <https://dicionariodetradutores.ufsc.br/pt/AdrienDelpech.htm>. Acesso em: 5 nov. 2020.

SANTOS. Joice Lemos dos. A recepção da obra de Jorge Amado na França. 2018. 275 fl. Tese (Livre-Docência) - Universidade Federal da Bahia. Instituto de Letras, Salvador, Bahia, 2018. Université Rennes 2. 
SAPIRO, Gisèle. Translation and the Field of Publishing. Translation Studies. 1:2, 2008, p. 154-166. Disponível em: <https://www.tandfonline.com/doi/abs/10.1080/14781700802113473>. Acesso em: 22 jun. 2020.

SAPIRO, Gisèle. The Sociology of Translation - a new research domain. In: BERMANN, Sandra; PORTER, Catherine (Eds.). A Companion to Translation Studies. Chichester, UK: Wiley Blackwell, 2014. p. 82-94.

SEREZA, Haroldo. Os passos de caranguejo do Prêmio Jabuti. Cult, n. 259, 8 jul. 2020. Disponível em: <https://revistacult.uol.com.br/home/premio-jabuti-passos-decaranguejo/>. Acesso em: 23 dez. 2020.

SORÁ, Gustavo. Traducir el Brasil: una antropologia de la circulación internacional de ideas. Buenos Aires: Libros del Zorzal,2003.

THOMSON-DEVEAUX, Flora. "As pessoas precisam estar prontas para Machado", diz tradutora. DW. 17 jun. 2020. Disponível em: <https://www.dw.com/pt-br/aspessoas-precisam-estar-prontas-para-machado-diz-tradutora/a-53830938>. Acesso em: 27 out. 2020.

TOOGE, Marly D' Amaro Blasques. Traduzindo o Brazil: o país mestiço de Jorge Amado. Revista Amerika, 31 maio 2014. Disponível em: <http://amerika.revues.org/5008>. Acesso em: 26 nov. 2020.

TORRES, Marie-Hélène Catherine. Traduzir o Brasil literário: história e crítica. Germana Henriques Pereira de Sousa, Clarissa Prado Marini, Sônia Fernandes e Aída Carla Rangel de Sousa (Trad.). Tubarão: Ed. Copiart; Florianópolis: PGET/UFSC, 2014.

VAIANO, Bruno. Tradução de Machado de Assis em inglês esgota em um dia nos EUA. Revista Superinteressante. Jun. 2020. Disponível em: $<$ https://super.abril.com.br/cultura/traducao-de-machado-de-assis-em-ingles-esgotatiragem-em-um-dia-nos-eua/>. Acesso em: 27 out. 2020.

VENUTI, Lawrence. The translator's invisibility: a history of translation. Second edition. London, New York: Routledge, 2008.

Translations on the Book Market. . Translation Changes Everything: Theory and Practice. London and New York: Routledge, 2013. p. 158-164.

VILAR, Ivi Fuentealba. A internacionalização de Clarice Lispector: aspectos da recepção da escritora brasileira na França. Revista da Anpoll, v. 1, n. 50, p. 197-207, Florianópolis, set./dez. 2019. 
W. W. NORTON \& COMPANY LTDA. Margaret Jull Costa. Disponível em: <https://www.wwnorton.co.uk/search/contributors?q=Margaret+Jull+Costa\&sort=titl e>. Acesso em: 4 nov. 2020.

WILLIAMS, Claire. "Para inglês ver": traduções de literatura brasileira na época dos megaeventos. Abriu, 2017, n. 6, p. 105-132. Disponível em:

<https://webcache.googleusercontent.com/search?q=cache:z6ZywD4ZKhMJ:https://r evistes.ub.edu/index.php/Abriu/article/download/abriu2017.6.6/21668+\&cd=1\&hl=pt -BR\&ct=clnk\&gl=br>. Acesso em: 04 dez. 2020.

WOOD, Michael. Um mestre entre ruínas. Mais! 21 jul. 2002. Disponível em: <https://www1.folha.uol.com.br/fsp/mais/fs2107200207.htm〉. Acesso em: 29 out. 2020.

ZAMBELLI, Paula Candido. Antologizando a nação: antologias literárias brasileiras, identidade e ideologia no Estado Novo (1937-1945). Amérique Latine Histoire et Memoire, Les Cahiers ALHIM, n. 33, 16 jun. 2017. Disponível em: https://journals.openedition.org/alhim/5718\#tocto1n5. Acesso em: 10 dez. 2020. 


\section{Anexo A}

Programa de Intercâmbio de Autores Brasileiros no Exterior

Exchange Program for Brazilian Authors Abroad

Edital

Public Notice

2016 


\section{Sumário/Summary}

Edital - Programa de Intercâmbio de Autores Brasileiros no Exterior Anexos

Public Notice - Exchange Program for Brazilian Authors Abroad Annexes 


\title{
Edital
}

\section{Programa de Intercâmbio de Autores Brasileiros no Exterior $n^{\circ} \mathbf{1 / 2 0 1 6}$}

\begin{abstract}
A Fundação Biblioteca Nacional torna público que oferecerá apoio financeiro a editoras e instituições culturais estrangeiras com o objetivo de promover a participação de autores brasileiros em eventos literários no exterior. Este procedimento, autorizado por meio de Decisão Executiva No 25 / FBN, de 18 /07/ 2016, será regido pelo Edital que se segue e pela Portaria MinC 29/2009, e supletivamente, pela Lei nº 8.666/93.
\end{abstract}

\section{Seção I - Objeto}

1. O Programa de Intercâmbio de Autores Brasileiros no Exterior, criado pela Fundação Biblioteca Nacional (FBN), instituição vinculada ao Ministério da Cultura, objetiva difundir a cultura e a literatura brasileiras, por meio da concessão de recursos financeiros a editoras e instituições culturais estrangeiras, com a finalidade de apoiar, parcial ou integralmente, o custeio das despesas de transporte internacional e/ou interurbano relacionadas à participação de autores brasileiros em eventos literários no exterior.

2. O Programa é destinado a editoras e instituições culturais estrangeiras que desejam promover atividades literárias com autores brasileiros no exterior.

2.1 Para efeitos deste edital serão considerados autores brasileiros aqueles nascidos no Brasil ou naturalizados. Autores que não se enquadrem nessas condições serão analisados mediante avaliação especial da Comissão Avaliadora do Programa.

2.2 Para efeitos deste edital serão consideradas instituições culturais pessoas jurídicas legalmente estabelecidas, tais como: centros culturais, universidades, festivais literários e afins. 


\section{Seção II - Condições para participação}

3. Podem participar deste edital editoras estrangeiras que tenham publicado obras de autores brasileiros, ou já adquirido os direitos para publicação, e desejam promover a participação desses autores em eventos literários internacionais.

3.1 Podem participar deste edital, instituições culturais estrangeiras que desejam organizar atividades literárias com autores brasileiros ou convidar autores brasileiros para períodos de residência no exterior.

3.2 As viagens e eventos previstos deverão ter início entre 20 de outubro e 31 de dezembro de 2016.

4. Os autores em questão deverão ter publicado no Brasil ao menos um livro nas áreas de literatura e humanidades, especialmente os seguintes gêneros: romance, conto, poesia, crônica, infantil, juvenil, história em quadrinhos, teatro, obra de referência, ensaio literário, ensaio social, ensaio de vulgarização científica.

\section{Seção III - Vigência}

5. O presente edital terá vigência até 31 de dezembro de 2016, podendo ser prorrogado, em caso de necessidade, por um período de até 12 (doze) meses.

6. Convocatórias específicas no âmbito do Programa poderão ser publicadas tendo em vista países, idiomas e temas estratégicos para a FBN.

\section{Seção IV - Recursos orçamentários}

7. Para atender aos objetivos deste edital, para o ano de 2016 estão previstos recursos no valor de $\mathrm{R} \$ 80.000$ (oitenta mil reais), provenientes da Lei Orçamentária Anual e do Fundo Nacional de Cultura, conforme disponibilidade orçamentária. 


\section{Seção V - Benefícios}

8. A editora ou instituição cultural poderá receber apoio de até US\$1.500,00 (mil e quinhentos dólares) por requerimento.

9. O apoio será calculado com base no orçamento apresentado pelo proponente, levando em consideração as despesas de transporte internacional e/ou interurbano do autor.

9.1. O apoio a requerimentos que apresentem locais de partida fora do Brasil será calculado de acordo com as especificidades de cada caso até o valor máximo US\$1.500,00 (mil e quinhentos dólares)

9.2. Caso os gastos do proponente com transporte sejam inferiores ao valor do apoio concedido, o saldo poderá ser utilizado em outras despesas necessárias para participação do autor nos eventos. O proponente precisará comprovar esses gastos no relatório das atividades desenvolvidas a ser encaminhado à FBN após a realização dos eventos.

10. A formalização da concessão do apoio será objeto de Termo de Compromisso redigido em língua portuguesa, firmado pelo responsável legal da editora ou instituição cultural estrangeira e pelo Presidente da FBN.

$10.1 \mathrm{O}$ apoio será pago em parcela única após a assinatura do Termo de Compromisso pelas duas partes.

11. Caso a transferência do recurso não se realize a tempo, as editoras e instituições que tiverem os requerimentos aprovados poderão tomar as medidas necessárias a fim de garantir a participação do autor nos eventos previstos.

11.1 As datas e a natureza dos eventos poderão ser reajustadas, mediante justificativa e após aprovação da FBN, caso qualquer fato superveniente prejudique ou altere a realização das atividades inicialmente planejadas.

12. Não serão beneficiados requerimentos que digam respeito a atividades já contemplados com apoio, inclusive institucional, do Ministério da Cultura ou de suas instituições vinculadas 
13. A concessão do apoio está condicionada à existência de disponibilidade orçamentária e financeira, caracterizando a seleção como expectativa de direito do proponente.

\section{Seção VI - Apresentação e envio das inscrições}

14. As inscrições poderão ser realizadas a partir da publicação do Edital e se encerrarão em 05 de setembro de 2016. As etapas de recebimento, habilitação e avaliação das inscrições seguirão o cronograma* abaixo:

\begin{tabular}{|c|c|c|c|c|c|c|}
\hline $\begin{array}{l}\text { Prazo para } \\
\text { recebimento } \\
\text { de } \\
\text { inscrições }\end{array}$ & $\begin{array}{l}\text { Divulgação } \\
\text { da lista } \\
\text { preliminar } \\
\text { de } \\
\text { inscrições } \\
\text { habilitadas }\end{array}$ & $\begin{array}{l}\text { Prazo para } \\
\text { envio de } \\
\text { recursos }\end{array}$ & $\begin{array}{l}\text { Divulgação } \\
\text { da lista } \\
\text { final de } \\
\text { inscrições } \\
\text { habilitadas }\end{array}$ & $\begin{array}{l}\text { Data da } \\
\text { reunião de } \\
\text { avaliação }\end{array}$ & $\begin{array}{l}\text { Divulgação } \\
\text { do } \\
\text { resultado }\end{array}$ & $\begin{array}{l}\text { Prazo para } \\
\text { envio de } \\
\text { recursos }\end{array}$ \\
\hline $05 / 09 / 2016$ & $13 / 09 / 2016$ & $15 / 09 / 2016$ & $16 / 09 / 2016$ & $21 / 09 / 2016$ & $28 / 09 / 2016$ & $30 / 09 / 2016$ \\
\hline
\end{tabular}

*Datas provisórias

14.1 Novas reuniões poderão ocorrer mediante o número de inscrições recebidas e conforme disponibilidade orçamentária.

15. As inscrições serão gratuitas.

16. As inscrições deverão ser apresentadas conforme o item 3 deste edital.

16.1 Os proponentes deverão enviar à FBN, no momento da inscrição, os seguintes documentos, digitalizados, preferencialmente por e-mail para o endereço intercambioautores@bn.br:

a) Itinerário do autor e agenda de eventos previstos, incluindo os convites das instituições organizadoras dos eventos literários (em português, inglês ou espanhol);

b) Orçamento global previsto para a participação do autor convidado no evento, em dólares americanos, incluindo eventuais aportes de terceiros;

c) Formulário de inscrição totalmente preenchido e assinado, digitado (Anexos I, II e III);

d) Anuência do autor ao pedido por meio de carta ou correio eletrônico;

e) Documento de identidade do autor; 
f) Documento de identidade do representante legal da editora/instituição estrangeira;

g) Registro legal da editora / instituição estrangeira;

h) Contrato de direitos de publicação estabelecido entre o autor/agente literário e a editora estrangeira, caso os proponentes sejam editoras estrangeiras, acompanhado de breve ementa em português, espanhol, francês ou inglês, assinada pelas mesmas partes no contrato.

i) Biografia resumida do autor.

16.2 O formulário de inscrição original devidamente assinado (alínea c) deverá obrigatoriamente ser encaminhado por via postal à FBN, no endereço:

Fundação Biblioteca Nacional

Centro de Cooperação de Difusão

Programa de Intercâmbio de Autores Brasileiros no Exterior

Rua da Imprensa, 16/1102 - Centro

20030-120 - Rio de Janeiro - RJ - Brasil

16.3 Inscrições por via postal devem ser encaminhadas para o endereço acima indicado.

16.4 Não serão aceitas inscrições por via postal recebidas após a data de 05 de setembro de 2016, conforme indicado no cronograma acima, independentemente da data de envio.

17. O proponente será o único responsável pela veracidade da proposta e dos documentos encaminhados, isentando a Fundação Biblioteca Nacional e o Ministério da Cultura de qualquer responsabilidade civil ou penal por eventuais equívocos.

\section{Seção VII - Etapa de habilitação}

18. Para a habilitação da inscrição será necessário o envio dos documentos e dos formulários, devidamente preenchidos, em conformidade com o item 16 deste Edital. 19. Compete ao Centro de Cooperação e Difusão/FBN (CCD/FBN) proceder ao exame de habilitação das inscrições e eventuais pedidos de reconsideração. 
20. Será desconsiderada a inscrição apresentada com ausência de informações que possa prejudicar a análise.

21. Apenas as inscrições habilitadas serão submetidas à fase de avaliação e seleção, sendo inabilitadas as inscrições que não cumprirem o disposto no item 14 deste Edital. 22. Após o término do prazo de recebimento de inscrições será divulgada em até 5 (cinco) dias úteis, no sítio eletrônico da Fundação Biblioteca Nacional (www.bn.br), a lista preliminar de projetos habilitados que conterá o nome do autor, do proponente e, nos casos de indeferimento do pedido, o motivo relacionado ao requerimento.

23. Caberá pedido de reconsideração da inabilitação, a ser enviado no prazo de 2 (dois) dias úteis, por meio de e-mail, a contar do dia subsequente da data de divulgação do resultado para o seguinte endereço: intercambioautores@bn.gov.br.

24. O resultado final da fase de habilitação será divulgado por meio de publicação no sítio eletrônico da Fundação Biblioteca Nacional (www.bn.br).

\section{Seção VIII - Etapa de avaliação e seleção}

25. O processo seletivo das inscrições dos projetos inscritos será realizado por uma Comissão Avaliadora constituída por:

a) Dois representantes da FBN, que poderão ser destacados dos seguintes órgãos específicos: Centro de Cooperação e Difusão, Centro de Pesquisa e Editoração e Centro de Coleções e Serviços aos Leitores;

b) Um representante do Ministério da Cultura ou instituições vinculadas;

c) Um representante do Departamento Cultural do Ministério das Relações Exteriores;

d) Um especialista em literatura e/ou tradução, preferencialmente profissional da área e/ou professor universitário.

26. A avaliação das inscrições ocorrerá na data provável de 21/09/2016.

27. A comissão adotará como critérios de seleção:

a) Contribuição das atividades a serem desenvolvidas para a divulgação da literatura e da cultura brasileira; 
b) Relevância da promoção do autor em eventos literários no exterior para a divulgação da literatura e da cultura brasileira;

c) Consistência e capacidade de execução da agenda de eventos propostas pela editora/instituição estrangeira.

27.1 As notas mínima e máxima para o critério previsto na alínea "a" serão, respectivamente, 1 e 5 ;

27.2 As notas mínima e máxima para o critério previsto na alínea "b" serão, respectivamente, 1 e 5 ;

27.3 As notas mínima e máxima para o critério previsto na alínea "c" serão, respectivamente, 1 e 5 ;

27.4 Em caso de empate, prevalece o projeto que receber maior nota no critério "a", e em seguida pelo critério "b". Persistindo o empate, o critério será o sorteio.

27.5 A pontuação mínima de classificação será 8 , sendo desclassificados os projetos que não a atingirem.

27.6 A fim de minimizar desigualdades, os requerimentos cujos autores sejam originários das regiões Centro-Oeste, Nordeste e Norte serão bonificados com 1 (um) ponto adicional.

27.7 Em consonância com as prioridades da política internacional brasileira e da política cultural do Ministério da Cultura, serão bonificados com 1 (um) ponto adicional os requerimentos de participação em acontecimentos nos países da América Latina, do Caribe e naqueles que fazem parte da Comunidade dos Países de Língua Portuguesa - CPLP: Angola, Cabo Verde, Guiné-Bissau, Moçambique, Portugal, São Tomé e Príncipe e Timor Leste.

27.8 Caberá à comissão avaliadora encaminhar à unidade gestora da seleção pública a lista de selecionados e a lista de classificados, que serão chamados no caso de eventuais desistências ou impedimentos dos projetos selecionados.

27.9 A lista de selecionados e a lista de classificados deverão conter:

I - nome da editora (ou instituição) e do autor;

II - país de origem;

III - nota obtida na avaliação; 
IV - valor do apoio;

$\mathrm{V}$ - nome dos membros da comissão de seleção.

27.10 Os requerimentos classificados poderão ser contemplados posteriormente em caso de disponibilidade de recursos, a critério da unidade gestora da seleção pública e respeitada a prioridade aos selecionados, a ordem decrescente de pontuação e o prazo de vigência da seleção pública.

28. O resultado da seleção será comunicado diretamente à editora contemplada por correio eletrônico, em até 5 (cinco) dias úteis após a reunião de avaliação, e ficará disponível no sítio eletrônico da FBN, bem como será publicado no Diário Oficial da União.

29. Caberá pedido de reconsideração da lista de projetos selecionados e dos valores concedidos, a ser enviado no prazo de 2 (dois) dias corridos, por meio de correio eletrônico, a contar do dia subsequente da data de divulgação do resultado, para intercambioautores@bn.gov.br.

29.1 Os pedidos de reconsideração serão analisados pelo Centro de Cooperação e Difusão em concordância com os demais membros da Comissão Avaliadora num prazo de 5 (cinco) dias corridos.

\section{Seção IX - Obrigações da editora ou instituição estrangeira}

30. Todo material de divulgação da participação do autor no evento ou publicações decorrentes deverão incluir o logotipo da Fundação Biblioteca Nacional assim como a seguinte referência, em português e no idioma local:

"Evento realizado com o apoio do Ministério da Cultura do Brasil / Fundação Biblioteca Nacional".

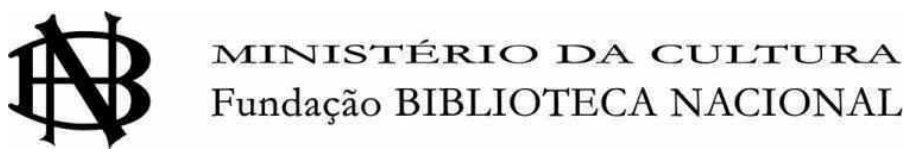

31. Até 30 dias após o término da agenda de eventos, a editora ou instituição proponente deverá apresentar um relatório detalhado com as seguintes informações: 
a) Descrição das atividades desenvolvidas, com documentação comprobatória (fotografia, cartazes, catálogos, material de imprensa, documentos emitidos pela organização do evento etc.), assinado pelo representante legal da editora ou instituição cultural, conforme modelo em anexo (Anexo IV);

b) Comprovantes (passagens, bilhetes de transporte ou cartões de embarque) dos deslocamentos previstos no itinerário apresentado e recibos de eventuais despesas necessárias para a participação do autor;

c) Recibos com as demais despesas realizadas em nome do autor que poderão ser consideradas mediante avaliação da FBN para compor o total concedido.

\section{Seção X - Penalidades}

32. A editora ou instituição beneficiada restituirá o valor recebido, atualizado desde a data de recebimento, acrescido de juros legais na forma da legislação aplicável aos débitos para com a Fazenda Nacional, nos seguintes casos:

a) Cancelamento do evento;

b) Descumprimento das condições constantes deste edital;

c) Constatação, a qualquer tempo, de falsidade documental ou de fato cuja gravidade incorra em prejuízo ao objetivo proposto;

d) Não-apresentação dos itens obrigatórios à prestação de contas (item 31 do Edital);

e) Utilização dos recursos em atividades não previstas neste edital;

33. O descumprimento de cláusulas deste Edital ou do Termo de Compromisso firmado entre a Editora e a FBN poderá implicar penalidades ou restrições para futuras inscrições de acordo com os seguintes critérios:

a) Desistência do projeto após o pagamento da bolsa: 1 (um) ano sem apresentar novos projetos ao Programa, além da devolução do valor concedido;

b) Adiamento da viagem sem consulta prévia à FBN: 1(um) ano sem apresentar novos projetos ao Programa, além da devolução do valor concedido. 


\section{Seção XI - Disposições Finais}

34. Este Edital estará disponível no endereço eletrônico da Fundação Biblioteca Nacional (www.bn.br) e do Ministério da Cultura do Brasil (www.cultura.gov.br) e será publicado no Diário Oficial da União.

35. Para esclarecimento de dúvidas, entrar em contato através do telefone +55 212220 2057 ou pelo e-mail intercambioautores@bn.gov.br.

36. Os materiais encaminhados pelos proponentes não serão devolvidos, cabendo à Fundação Biblioteca Nacional a decisão sobre seu arquivamento ou destruição.

37. As candidaturas inscritas, selecionadas ou não, passarão a fazer parte do cadastro da Fundação Biblioteca Nacional para fins de pesquisa, documentação e mapeamento da produção cultural brasileira.

38. O ônus da participação no processo seletivo, incluídas as despesas com cópias, correio e emissão de documentos é de exclusiva responsabilidade do proponente.

39. O ato de inscrição pressupõe que o proponente manifesta plena e irretratável anuência com relação a todos os itens do presente edital.

40. Os casos omissos serão solucionados pela direção da Fundação Biblioteca Nacional.

41. Eventuais irregularidades relacionadas aos requisitos de participação, constatadas a qualquer tempo, implicarão a inabilitação da inscrição.

\section{Luiz Fernando Zugliani}

\section{Presidente em exercício}




\section{Programa de Intercâmbio de Autores Brasileiros no Exterior Anexo I - Formulário de inscrição}

\section{Dados da editora / instituição}

\begin{tabular}{|c|c|c|}
\hline \multicolumn{3}{|l|}{ Nome da empresa / instituição } \\
\hline \multicolumn{3}{|l|}{ Nome de fantasia } \\
\hline \multicolumn{3}{|l|}{ Endereço } \\
\hline Cidade & País & Código postal \\
\hline Telefone & Fax & Website \\
\hline $\begin{array}{l}\text { Número do registro da } \\
\text { empresa* }\end{array}$ & Ano de inauguração & $\begin{array}{l}\text { Número de livros impressos/digitais } \\
\text { publicados no ano anterior à inscrição } \\
\text { (para preenchimento da editora) }\end{array}$ \\
\hline Representante legal & \multicolumn{2}{|l|}{ Cargo } \\
\hline E-mail & \multicolumn{2}{|l|}{ Telefone } \\
\hline
\end{tabular}

\section{Dados do autor}

\begin{tabular}{|l|l|l|}
\hline \multicolumn{2}{|l|}{ Nome } & Telefone \\
\hline Endereço & Número da identidade & Número do CPF \\
\hline E-mail & ISBN & $\begin{array}{l}\text { Ano de publicação ou previsão } \\
\text { de lançamento }\end{array}$ \\
\hline estrangeira publicada pela editora & & Ano de publicação no Brasil \\
\hline Editora brasileira da obra & ISBN & \\
\hline
\end{tabular}

\section{Dados bancários da editora / instituição}

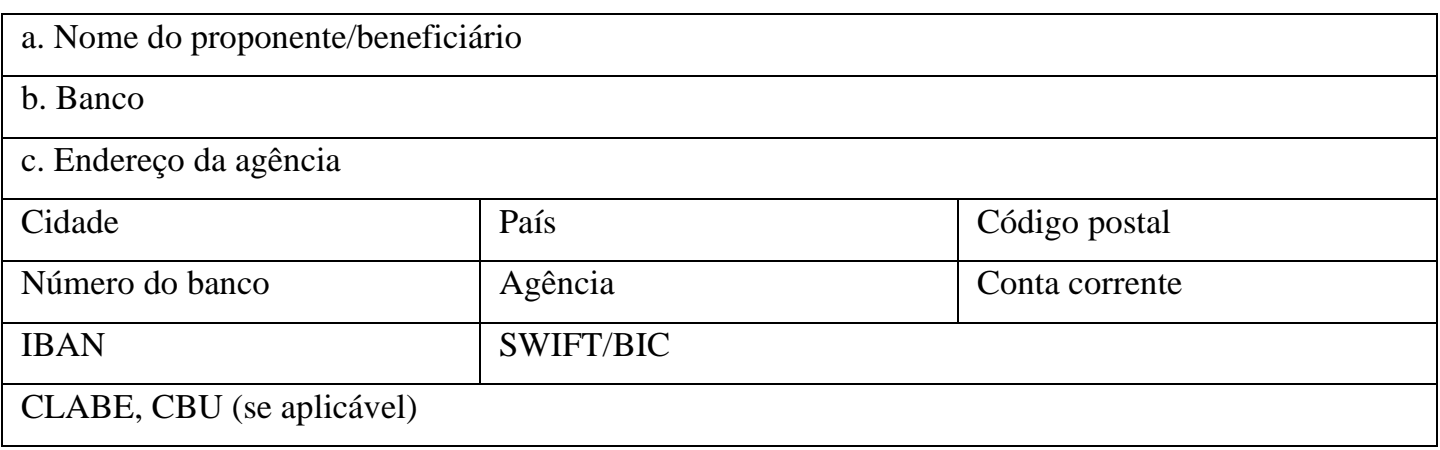




\section{Informações adicionais}

1. A editora/instituição solicitante já recebeu outras bolsas/subsídios/incentivos de outras instituições, públicas ou privadas, brasileiras ou internacionais para a realização das atividades descritas nesta inscrição?

( ) Não.

( ) Sim. Qual?

2. A editora/instituição solicitante recebeu algum apoio, inclusive institucional, do Ministério da Cultura do Brasil, ou de suas entidades vinculadas para a realização das atividades descritas nesta inscrição?

( ) Não.

( ) Sim. Qual?

2. Como conheceu o Programa de Residência de Tradutores Estrangeiros no Brasil?

( ) Agentes Literários

( ) Autores

( ) Editoras

( ) Tradutores

( ) Feira de Livro e/ou Evento de Literatura. Qual?

( ) Outros. Especifique:

\section{Declaração}

\section{À FUNDAÇÃO BIBLIOTECA NACIONAL,}

$\mathrm{Eu}$, , venho requerer a inscrição da obra acima citada no Programa de Intercâmbio de Autores Brasileiros no Exterior.

Declaro para os devidos efeitos, sob as penas da lei brasileira, que as informações por mim prestadas constituem fiel expressão da verdade, e que aceito as normas descritas no Edital do referido Programa.

$\underset{\text { Local }}{-} \quad \frac{1}{\text { Data }} \quad \frac{}{\text { Assinatura do representante legal }}$




\section{Programa de Residência de Tradutores Estrangeiros no Brasil Anexo II - Comprovação da cessão dos direitos autorais patrimoniais de obra \\ (para preenchimento caso a editora estrangeira seja a proponente)}

Declaro, na qualidade de representante legal da situada em , ser ela titular dos direitos autorais patrimoniais, para fins de tradução e publicação em língua da obra original publicada em português no Brasil, com o título:

de Autoria de
, de acordo com o instrumento legal

efetivado com Autor e/ou seu representante legal, cuja cópia segue em anexo.

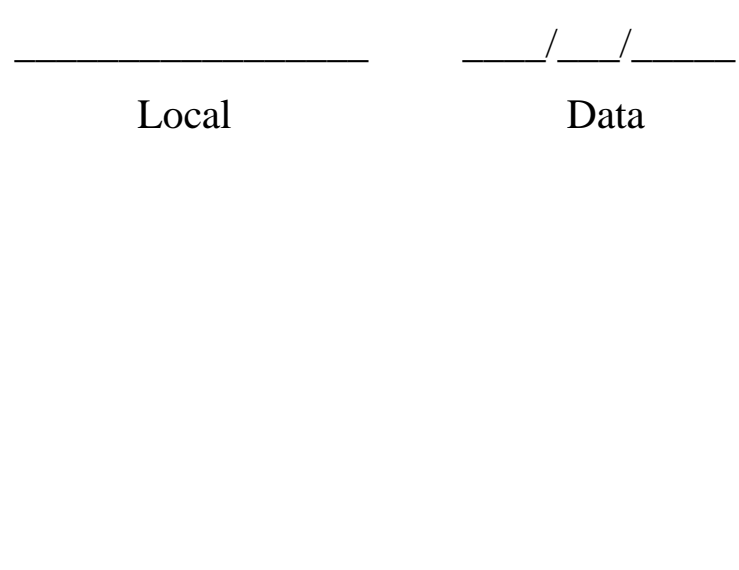

Representante legal da editora (assinatura e carimbo) 


\section{Anexo III}

\section{Descrição das atividades previstas}

\section{Description of planned activities}

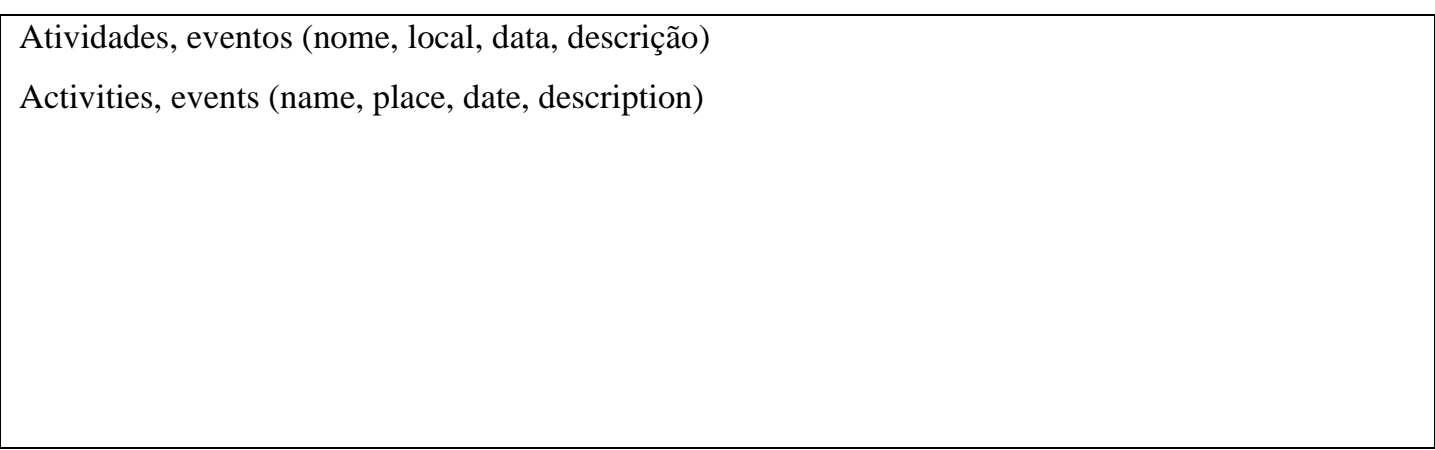

Orçamento dos custos de transporte previstos

Budget for transportation expenses

Assinatura / Signature 


\section{Public Announcement International Exchange Program For Brazilian Authors}

No. 1/2016

The National Library of Brazil (FBN) announces a funding scheme to support foreign publishers and cultural institutions bring Brazilian authors to attend literary events abroad in order to promote Brazilian culture and literature. This procedure, authorized by Executive Decision n ${ }^{\circ} .25$ - FBN of 18 /07//2016, will be governed by the following Notice and by Ministry of Culture Directive 29/2009, as well as by Law no. 8666/93.

\section{Part I - Aim}

1. The International Exchange Program for Brazilian Authors, launched by the National Library Foundation of Brazil, a body of the Ministry of Culture, aims at promoting Brazilian Culture and Literature through the concession of grants for both publishers and foreign cultural institutions. The purpose of the Program is to provide partial coverage of international or interurban transportation expenses related to the participation of Brazilian authors at international literary events.

2. The Grant is aimed at both foreign publishers, who wish to promote the works of Brazilian writers at literary events as well as foreign cultural institutions, which host literary activities and which would benefit from the presence of Brazilian authors.

2.1 For the purposes of the Program, either Brazilian nationals or naturalized Brazilian citizens will be considered as authors. Authors who do not meet these requirements will be the object of special scrutiny by the evaluation committee. 2.2 Cultural institutions, within the terms of this announcement, are established legal entities such as cultural centres, universities, literary fairs and the like. 


\section{Part II - Eligibility}

3. Any foreign publishers that have already published works by Brazilian authors or those that have acquired the publication rights and wish to promote them by bringing their authors to international literary events can apply for this grant.

3.1 Foreign cultural institutions that wish to host literary events with the presence of Brazilian authors or those that wish to offer a residency abroad may apply.

3.2 The terms of this announcement are valid for events and travel grant applications scheduled to take place from October 20th to December 31st 2016. 4. The eligible authors are those that have already published at least one book in the area of literature or arts (humanities), particularly in the following genres: novels, short stories, poetry, chronicle, children's literature, graphic novels, theater, reference works, literary essays, essays in social science and in essays in popular science essays.

\section{Part III - Duration of Program}

5. The terms of this announcement are valid until December 31st 2016. The validation may be prorogated for a 12-month period.

6. Specific guidelines within the Program may be published with reference to countries, languages and strategic themes concerning FBN.

\section{Part IV - Available Funds}

7. Eighty thousand Reais ( $\mathrm{R} \$ 800,000.00)$ have been made available for 2016 Program through the Annual Budgetary Law (LAO) and/or Brazilian National Culture Fund (FNC) upon financial and budgetary availability. 


\section{Part V - Grants}

8. A grant of up to US\$1,500 (one thousand five hundred dollars) per application may be awarded to either a publisher or cultural institution.

9. In order o define the amount of each grant the evaluation committee will consider the estimated international and interurban transportation expenses.

9.1 If the proposal requires the author to travel from places other than Brazil, the value of the grant will be calculated by taking this fact into account but, in any case, it will not exceed the maximum of US\$ 1,500 (one thousand five hundred dollars).

9.2 If the transportation expenses add up to less than the granted value, the remaining funds can be used in other expenses necessary for the author's participation in the events. After the completion of the events, the applicant will have to show proof of these expenses in the report of activities.

10. The awarded grant is formalized through the Terms of Agreement document drafted in Portuguese* signed by the legal signatory of the publisher/institution and the Chairman of the National Library.

* N.B. Brazilian Law requires all contracts to be written in Portuguese.

10.1 The grant will be paid in full after the Terms of Agreement have been signed by both parties.

11. In case the transfer of the funds cannot be made in good time for the proposed event, the publisher/institution may undertake the necessary commitments in order to ensure that the author participates in the scheduled events.

11.1 The dates and nature of the events may be modified, if approved by FBN, in case any supervening facts interfere with the fulfilment of the activities initially planned.

12. Applications regarding authors who have already been awarded with financial or institutional support, either from the Ministry of Culture or bodies linked to it to carry out the same activity, will not be eligible for the National Library grant. 
13. The awarding of grants is contingent upon the availability of budgetary and financial resources and, selection is at the discretion of the FBN and the Brazilian Ministry of Culture.

\section{Part VI - Applications}

14. Applications will be available from the date of this Notice's publication until September 5th, 2015, according to the following schedule*:

\begin{tabular}{|c|c|c|c|c|c|}
\hline $\begin{array}{l}\text { Deadline } \\
\text { for } \\
\text { application }\end{array}$ & $\begin{array}{l}\text { Annoucement } \\
\text { of } 1 \text { st list of } \\
\text { eligible } \\
\text { applications }\end{array}$ & $\begin{array}{l}\text { Dealine for } \\
\text { reconsideration } \\
\text { requests }\end{array}$ & $\begin{array}{l}\text { Annoucement } \\
\text { of final list of } \\
\text { eligible } \\
\text { applications }\end{array}$ & $\begin{array}{l}\text { Evaluation } \\
\text { meeting }\end{array}$ & $\begin{array}{l}\text { Annouce- } \\
\text { ment of } \\
\text { selected } \\
\text { applications }\end{array}$ \\
\hline $05 / 09 / 2016$ & $13 / 09 / 2016$ & $15 / 09 / 2016$ & $16 / 09 / 2016$ & $21 / 09 / 2016$ & $26 / 09 / 2016$ \\
\hline
\end{tabular}

* Presumable dates

14.1 Additional selection meetings may be scheduled on the basis of the number of applications received as well as financial and budgetary availability.

15. Applications will be free of charge.

16. Applications should be made in keeping with the instructions under Item 3.

16.1 Applicants must submit to FBN the following documents in digital format preferably by email at intercambioautores@bn.gov.br :

a) Author's itinerary with a list of scheduled events including invitations from the organizers of the literary events (in Portuguese, English or Spanish);

b) Estimated cost for the participation of the guest author in the proposed event including eventual third party contributions (in American Dollars);

c) Fully completed application form, signed in printed format (Annexes I, II and III);

d) Acceptance of invitation by the author either by letter or e-mail;

e) Author's identity document;

f) Publisher's or institution's legal representative identity document; 
g) Publisher's or institutions' legal registration;

h) Publishing rights contract between the author/literary agent and foreign publisher - in case the foreign publisher is applying -, followed by a summary in Portuguese, English, French or Spanish, signed by the same parties;

i) Author's abridged biography.

16.2 The original application forms (document "c" above) must be mailed to FBN at:

Fundação Biblioteca Nacional

Centro de Cooperação e Difusão

Programa de Intercâmbio de Autores Brasileiros no Exterior

Rua da Imprensa, 16/1102 - Centro

20030-120 - Rio de Janeiro - RJ - Brasil

16.3 Applications sent by regular mail must be sent to the above address.

16.4 Requests sent by regular mail will only be accepted until the September 5th 2015 regardless of the posting date.

17. The applicant is uniquely responsible for the truthfulness and accuracy of their proposal and documents, thus, exempting both the National Library of Brazil and its Ministry of Culture from any civil or criminal responsibility concerning random errors or equivocations.

\section{Part VII - Assessment of the Eligibility of Applications}

18. For any application to be considered, a fully completed application package needs to be included in accordance with item 16 .

19. The Center for Cooperation and Dissemination (Centro de Cooperação e Difusão, CCD) at the Naitonal Library is the body responsible for assessing the eligibility of the applications as well as any appeals

20. If an application is incomplete, thus, preventing the assessors from analysing it, it will be excluded. 
21. Only applications complying with the terms described under item 16 will be included in the eligibility or selection phases.

22. Within 5 (five) business days after each application deadline, the preliminary results of the application's eligibility assessment will be announced in a list containing the name of the author and of the applicant. Should an application be deemed invalid, a reason stating why it was declared invalid will also be included in the list.

23. If an application is rejected, the applicant will be able to appeal within 2 (two) business days from the date of the publication of results by email at intercambioautores@bn.gov.br

24. The result of the eligibility phase will be published at the National Library website (www.bn.br).

\section{Part VIII - Evaluation and Selection}

25. The selection process will be carried out by an evaluation committee constituted by the following members:

a) Two National Library representatives that may be chosen from the following unities: Centre for Cooperation and Dissemination, Centre for Publishing and Research and Centre for Collections and Reader's Services;

b) A representative from the Ministry of Culture or linked institution;

c) A representative from Ministry of External Relations' Cultural Department;

d) An expert in Literature and/or Translation, preferably a professional in these areas and/or a University Professor.

26. The selection of the applications will take place on the presumable date of September 21st, 2016.

27. The committee will adopt the following selection criteria:

a) Level of contribution to the dissemination of Brazilian literature and culture ensuing from the proposed events;

b) Relevance of the promotion of Brazilian literature and culture that the author will be able to offer at literary events abroad; 
c) Coherence and capacity of the Foreign Publisher to carry out its proposed event program successfully.

27.1 The minimum and maximum scores to be awarded under item "a" above will be respectively 1 and 5;

27.2 The minimum and maximum scores to be awarded under item "b" above will be respectively 1 and 5;

27.3 The minimum and maximum scores to be awarded under item "c" above will be respectively 1 and 5;

27.4 In case of a tie, the application with the highest score under criterion "a" will be the winner followed by "b". However, if a tie remains, the decision will be made by a drawing of lots.

27.5 The minimum score for an application to be selected is 8 and, by the same token, any application that fails to achieve the minimum score will be rejected. 27.6 In order to reduce inequalities in Brazil, authors from the Centre-Western, North-Eastern and Northern regions will be awarded an additional score of 1 . 27.7 In agreement with the priorities of the Brazilian foreign policy and the cultural policy of the Ministry of Culture, a bonus point will be granted to the score for an author's participation in events in the countries of Latin America and the Caribbean and member countries of the Community of Portuguese Language Speaking Countries (CPLP), namely: Angola, Cape Verde, GuineaBissau, Mozambique, Portugal, São Tomé and Príncipe and East Timor.

27.8 The evaluation committee will submit the list of selected proposals along with a classification of the winning proposals to the public selection managing unit so that if any author is unable to attend or should other impediments occur, other selected applicants may be eventually called.

27.9 The list of selected proposals along with a classification of the winning proposals will contain the following details:

I - name of the publisher, or institution, and the author;

II - country of origin;

III - score awarded in the evaluation;

IV - value of the grant; and 
$\mathrm{V}$ - name of the evaluation committee members.

27.10 The classified proposals may be awarded grants at a later date if resources are available and on the basis of the discretion of the public selection managing unit provided that the descending score order is respected within the period which applies for the said selection process.

28. The final selection results will be announced by email directly to the publisher under consideration until 5 (five) calendar days after the evaluation meetings and will be made available on the National Library website, as well as published in the Official Register of Brazil.

29. Appeals to re-evaluate the list of selected proposals and granted values may be submitted within 2 (two) working days following the date of the publication of the results by mail at intercambioautores@bn.gov.br.

29.1 The Centre for Cooperation and Dissemination Book Centre will be responsible for re-evaluating any appeal, in agreement with the members of the evaluation committee, within 5 (five) calendar days.

\section{Part IX - Publisher's / Institution's Obligations}

30. Any material used to promote an event with the proposed author or publications that may ensue from it must include the logo of the National Library as well as the following acknowledgement in Portuguese and in the local language:

"Evento realizado com o apoio do Ministério da Cultura do Brasil / Fundação Biblioteca Nacional"

'Event sponsored by the Ministry of Culture of Brazil/ National Library Foundation'

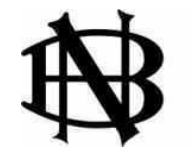

MINISTÉRIO DA CULTURA Fundação BIBLIOTECA NACIONAL

31. Within 30 days after the event, the publisher / institution must submit a detailed report with the following information: 
a) Description of the activities as well as documentary evidence (photographs, posters, catalogues, press releases and the like), signed by the legal representative of the publisher/institution, as the model attached (Annex IV);

b) Evidence (air tickets, travel tickets, boarding cards) of the travel itinerary that the publisher/institution listed in their application;

c) Receipts for the expenses incurred on behalf of the author, which might be considered as valid after FBN's assessment.

\section{Part X - Penalties}

32. Should any of the cases listed below occur, the publisher/institution will be required to refund the granted value in full, including the legal interest accrued from the date that it was received to the Brazilian Treasury in accordance with the Brazilian legislation:
a) Cancellation of the event;
b) Non-compliance with the terms of this announcement;
c) Evidence at any point that documents were falsified or that any serious incidents might have been detrimental to the aims of the Program;
d) Failure to submit the mandatory report (item 31);
e) Use of resources for activities not listed in this announcement.

33. Noncompliance with the terms and conditions provided in this Notice and as defined in the Agreement may entail the following penalties and restrictions concerning future applications:

a) Cancellation of the project after receiving the grant: 1 (one) year without submitting new applications, besides the refund;

b) Postponement of the author's trip without prior consultation: 1 (one) year without submitting new applications, besides the refund; 


\section{Part XI - Final Remarks}

34. This announcement will be available on the site of the National Library of Brazil (www.bn.br/) the Ministry of Culture of Brazil (www.cultura.gov.br/) and published in the Brazilian Official Gazette.

35. In case of queries, kindly phone $+55212220-2057$ or send an e-mail to intercambioautores@bn.gov.br.

36. The materials submitted along with the application will not be returned to the applicant, and the National Library will decide whether to archive or destroy them at a later date.

37. All submitted applications, successful or not, will be recorded by the National Library or the purposes of monitoring, documentation and mapping of the Brazilian cultural production.

38. The costs incurred to participate in this selection process, including copies, postage, document issue and the like, are the sole responsibility of the applicant.

39. By submitting the application, the applicant expressly acknowledges that he/she fully and irrevocably consents to and agrees with all of the items contained in this announcement.

40. Any overlooked matters shall be resolved by the National Library Board.

41. Any irregularities pertaining to participation requirements, discovered at any time, will entail disqualification of the application.

\section{Luiz Fernando Zugliani}

Acting President 


\section{International Exchange Program For Brazilian Authors Annex I - Application Form}

\section{Details of publisher/institution}

\begin{tabular}{|l|l|l|}
\hline \multicolumn{2}{|l|}{ Name of the company / institution: } \\
\hline \multicolumn{2}{|l|}{ Trading as (for publishing houses): } \\
\hline Adress: & Country: & \multicolumn{2}{l|}{ Postal Code: } \\
\hline City: & Fax: & Website \\
\hline Telephone: registration & $\begin{array}{l}\text { Date of the start of the } \\
\text { business: }\end{array}$ & $\begin{array}{l}\text { Number of published books } \\
\text { hardcopies/digital formats in the year } \\
\text { prior to application: }\end{array}$ \\
\hline $\begin{array}{l}\text { Company } \\
\text { Lumber*: }\end{array}$ & Post held: \\
\hline Legal representative: & Telephone: \\
\hline E-mail: & \multicolumn{2}{|l}{} \\
\hline
\end{tabular}

\section{Details of the autor}

\begin{tabular}{|l|l|l|}
\hline \multicolumn{2}{|l|}{ Name: } & Telefone \\
\hline Address: & ID number: & $\begin{array}{l}\text { Tax registration number } \\
\text { (CPF): }\end{array}$ \\
\hline E-mail: & Date of publication: \\
\hline $\begin{array}{l}\text { Works published by the } \\
\text { foreign publisher: }\end{array}$ & ISBN: & Date of publication in Brazil: \\
\hline $\begin{array}{l}\text { Brazilian Publisher of the } \\
\text { work: }\end{array}$ & ISBN: \\
\hline
\end{tabular}

\section{Banking details of the Publisher / institution}

\begin{tabular}{|l|l|l|}
\hline Name applicant / awardee: \\
\hline Bank details: \\
\hline \multicolumn{2}{|l|}{ Address of the bank in which the account is held: } \\
\hline City: & Country: & Postal code: \\
\hline Number of the bank: & Branch: & Current account number: \\
\hline IBAN & SWIFT/BIC \\
\hline CLABE, CBU (When appropriate)
\end{tabular}




\section{Aditional details}

1. Has the publisher/institution applying for the grant already requested scholarships/ support/incentive grants from other Brazilian or foreign state or private bodies for the activities described in this application?

( ) No.

( ) Yes. Please, provide details

2. Has the publisher/institution applying for the grant received any support, financial or institutional, either from the Ministry of Culture of Brazil or bodies linked to it to carry out the activities described in this application?

( ) No.

( ) Yes. Please, provide details

3. How did you hear about the International Exchange Program for Brazilian Authors?

( ) Literary Agents

( ) Authors

( ) Publishers

( ) Translators

( ) Book fair/Literary event. Please provide details

( ) Other. Please provide details:

\section{Statement to Fundação Biblioteca Nacional}

I, the undersigned, , declare that I wish to apply for the aforementioned work to be considered for an International Exchange Program for Brazilian Authors Grant.

I also declare, for the purposes of this application and under the Law of Brazil, that the details provided by me in this application are true and that I accept the terms contained in the official Announcement of the aforementioned grant program.

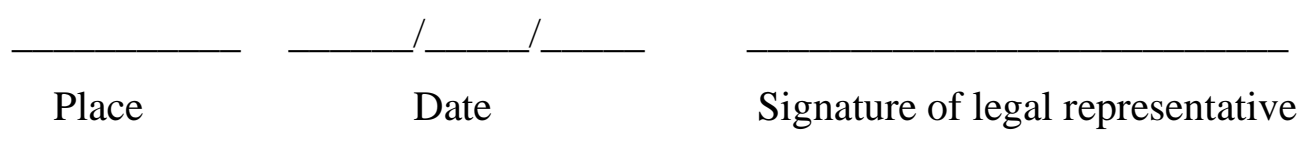




\section{International Exchange Program For Brazilian Authors Annex II - Proof of assignment of Copyright For the Work (to be completed by the foreign publisher if it is the applicant for the grant)}

I hereby declare, as the legal representative of based in , holder of the copyright for the translation and publication in language from the original published in Portuguese in Brazil, under the title of , by (name of the Author) in accordance with the legal agreement made with the Author and/or his/her legal representative, the copy of which is hereto attached.

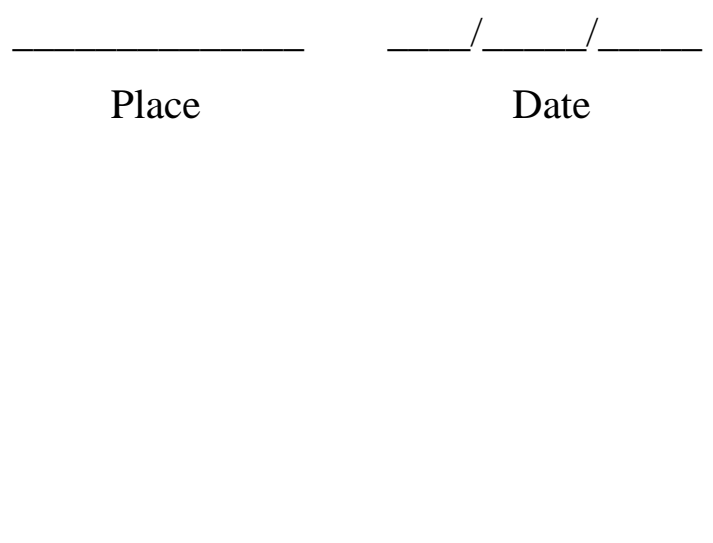

Legal Representative (signature \& stamp) 


\section{Anexo III}

\section{Descrição das atividades previstas}

\section{Description of planned activities}

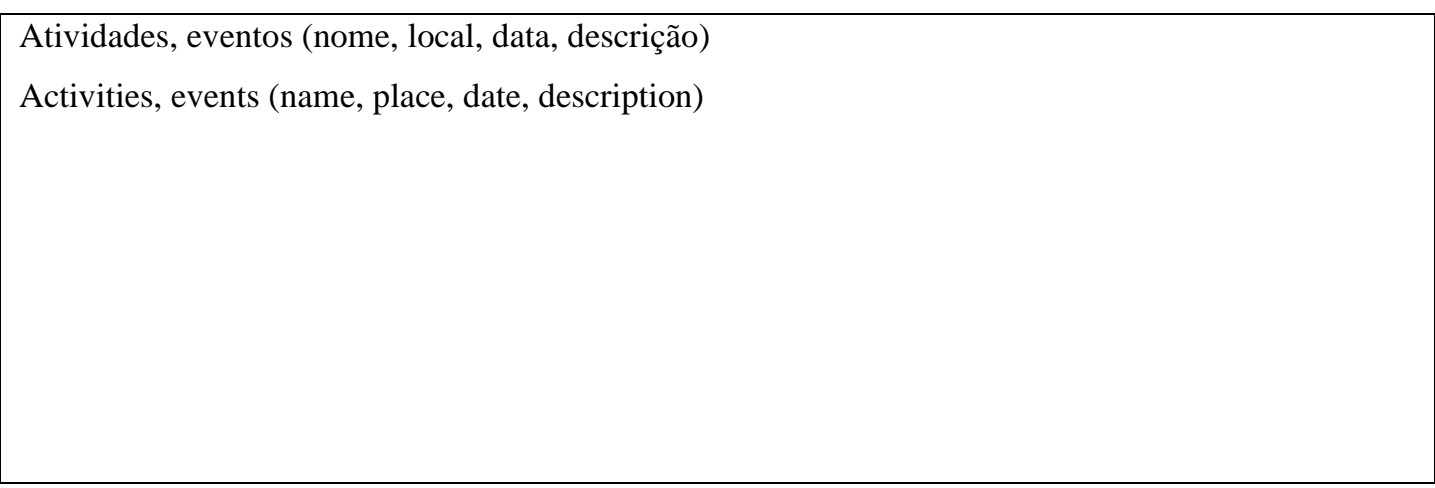




\section{Anexo IV}

\section{Relatório - Programa de Intercâmbio de Autores Brasileiros Report - Exchange Program for Brazilian Authors}

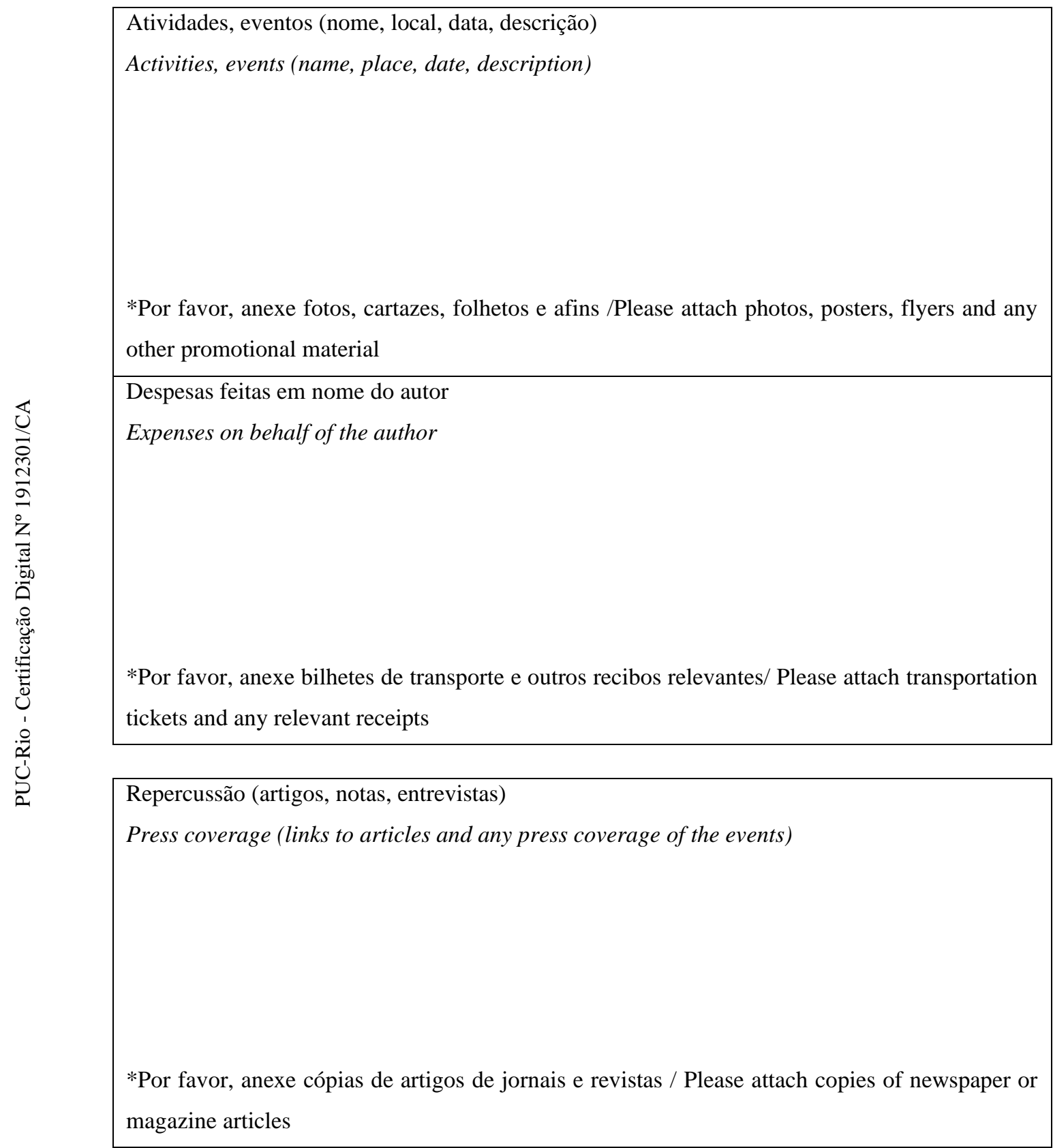

Assinatura / Signature 


\section{Anexo B}

MINISTÉRIO DA CUITURA
Fundação BIBLIOTECA NACIONAL

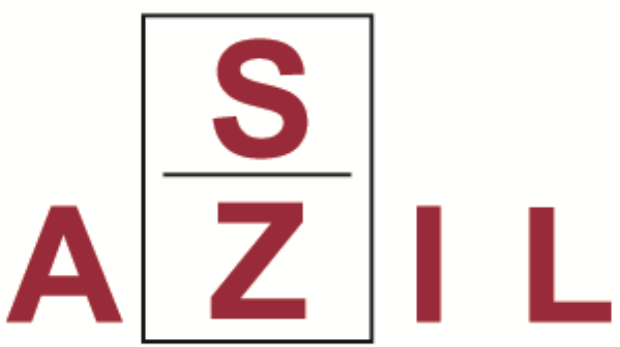

LITERATURE TRANSLATION GRANT

Edital de Abertura

Public Notice

2018-2020 
Edital de Abertura do Programa de Apoio à Tradução e à Publicação de Autores Brasileiros no Exterior 2018-2020

Anexos

Public Notice - Support Program for the Translation and Publication of Brazilian Authors Abroad 2018-2020

Annexes 


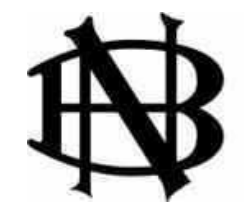

\title{
MINISTÉRIO DA CUITURA Fundação BIBLIOTECA NACIONAL
}

\section{Edital N 1 - 2018 | Abertura do Programa de Apoio à Tradução e à Publicação de Autores Brasileiros no Exterior 2018-2020}

\begin{abstract}
A Fundação Biblioteca Nacional torna público que oferecerá apoio financeiro às editoras estrangeiras que desejam traduzir, publicar e distribuir, no exterior, obras de autores brasileiros previamente publicadas no Brasil. Este procedimento, autorizado por meio de Decisão Executiva No 25 / FBN, de 21 / 06 /2018, será regido pelo Edital que se segue e pela Portaria MinC 29/2009, e supletivamente, pela Lei nº 8.666/93.
\end{abstract}

\section{Seção 1 - Objeto}

1. O Programa de Apoio à Tradução e à Publicação de Autores Brasileiros no Exterior, criado pela Fundação Biblioteca Nacional (FBN), instituição vinculada ao Ministério da Cultura, objetiva difundir a cultura e a literatura brasileiras no exterior, com a concessão de apoio financeiro à tradução e à publicação de obras de autores brasileiros no exterior.

2. O Programa é oferecido a editoras estrangeiras que desejam traduzir para qualquer idioma, publicar e distribuir, no exterior, em forma de livro impresso ou digital, obras de autores brasileiros anteriormente publicadas em português no Brasil.

2.1. Para efeitos deste Edital serão considerados autores brasileiros aqueles nascidos no Brasil ou naturalizados. Autores que não se enquadrem nessas condições serão analisados mediante avaliação especial da Comissão Avaliadora do Programa.

2.2. O Programa é também oferecido a editoras da Comunidade de Países de Língua Portuguesa (CPLP) que desejam publicar e distribuir obras de autores brasileiros em seus países. 
3. O Programa poderá conceder apoio a propostas de tradução e/ou publicação no âmbito da literatura e de humanidades, especialmente os seguintes gêneros: romance, conto, poesia, crônica, infantil, juvenil, história em quadrinhos, teatro, obra de referência, ensaio literário, ensaio social, ensaio de vulgarização científica e antologias de poemas e contos, integrais ou em parte.

3.1. Com o objetivo de ampliar a divulgação da literatura e da produção intelectual brasileira, projetos de coletâneas de ensaios, contos e poemas poderão incluir textos inéditos no Brasil, mediante avaliação especial da Comissão Avaliadora do Programa.

4. O apoio poderá ser atribuído às editoras com projetos de:

a) traduções inéditas;

b) novas traduções;

c) reedições de obras já traduzidas no país e que estejam esgotadas e fora de mercado há pelo menos três anos;

d) no caso de editoras da Comunidade de Países de Língua Portuguesa (CPLP), edições inéditas ou reedições de obras já publicadas no país que estejam esgotadas e fora de mercado há pelo menos três anos;

4.1. A concessão do apoio tem como objetivo principal custear, parcial ou totalmente, as despesas de editoras estrangeiras com a tradução da obra de autores brasileiros no exterior. As despesas de edição e impressão serão consideradas mediante avaliação especial da Comissão Avaliadora do Programa.

4.2. O apoio concedido a projetos de tradução de livros de história em quadrinhos e das obras do segmento infantil e juvenil poderá contemplar tanto os custos de tradução quanto os custos de edição e impressão.

4.3. O apoio concedido a projetos de editoras da Comunidade de Países de Língua Portuguesa (CPLP) contemplará os custos de edição e impressão.

5. Convocatórias específicas do Programa poderão ser divulgadas conforme o interesse da FBN, tendo em vista, por exemplo, efemérides, idiomas, autores em domínio público, e gêneros especiais. 


\section{Seção 2 - Vigência}

6. A vigência do presente Edital será de 24 (vinte e quatro meses), a contar da data de publicação no Diário Oficial da União, podendo ser prorrogada, em caso de necessidade, por um período de até 12 (doze) meses.

\section{Seção 3 - Recursos orçamentários}

7. Para atender aos objetivos deste Edital, estão previstos em 2018 recursos no valor de $\mathrm{R} \$ 30.000,00$ (trinta mil reais), provenientes da Ação 20ZF - Promoção e Fomento à Cultura Brasileira da LOA - Lei Orçamentária Anual e/ou do FNC Fundo Nacional de Cultura tendo em vista disponibilidade orçamentária da FBN ou outra entidade ou órgão público em parceria com a FBN.

7.1. A destinação financeira para os exercícios seguintes estará condicionada à existência de disponibilidade orçamentária e financeira, nos termos descritos no caput.

\section{Seção 4 - Condições para participação}

8. Podem participar deste Edital as editoras estrangeiras regularmente estabelecidas em seus países de origem.

9. Poderão ser reapresentadas propostas que não tenham sido contempladas em editais anteriores da FBN, desde que respeitem as normas definidas neste Edital.

10. Não serão aceitas inscrições de editoras que tenham compromissos pendentes com a FBN e que tenham sofrido sanções decorrentes de descumprimentos de obrigações para com a FBN, em conformidade com os casos descritos na Seção 11 deste Edital. 11. As editoras dos países da CPLP deverão observar o Acordo Ortográfico da Língua Portuguesa de 1990 na edição das obras de autores brasileiros contempladas pelo Programa, com exceção daquelas oriundas de países onde o acordo ainda não tenha entrado em vigor em caráter definitivo e obrigatório.

12. É vedada a participação de proponentes que possuam dentre os seus dirigentes: 
a) Cônjuge, companheiro ou parente em linha reta, colateral ou por afinidade, até o terceiro grau, de servidores, colaboradores, terceirizados, estagiários e prestadores de serviço relacionados ao Ministério da Cultura, inclusive, com integrantes da Comissão Avaliadora deste Edital;

b) Servidor, colaborador, terceirizado, estagiário e prestador de serviço relacionado ao Ministério da Cultura, suas Secretarias ou Instituições Vinculadas;

c) Membro do Poder Executivo, Legislativo, Judiciário, do Ministério Público ou do Tribunal de Contas da União, ou respectivo cônjuge ou companheiro ou parente em linha reta, colateral ou por afinidade até o $3^{\circ}$ grau.

12.1. Para a efetividade da vedação, o proponente deverá preencher declaração em que nega a ocorrência destas hipóteses (Anexo 1).

\section{Seção 5 - Benefícios}

13. A FBN concederá apoio financeiro de US\$1.000,00 (mil dólares americanos) até US\$ 6.000,00 (seis mil dólares americanos) para projetos de tradução e/ou publicação inéditos ou de nova tradução e de até US\$ 3.000,00 (três mil dólares americanos) para projetos de reedição, conforme item 4 deste Edital.

13.1. O apoio a ser concedido poderá considerar, em especial, as despesas com a tradução da obra e, excepcionalmente, custos de edição, revisão e impressão da publicação.

13.2. O apoio a ser concedido tem caráter supletivo, cabendo à editora proponente a responsabilidade pela proposta.

13.3. Nos casos de solicitação de editoras da Comunidade de Países de Língua Portuguesa (CPLP) o apoio a ser concedido considerará custos de edição, revisão e impressão da publicação.

14. A concessão do apoio está condicionada à existência de disponibilidade orçamentária e financeira, caracterizando a seleção como expectativa de direito do proponente. 


\section{Seção 6 - Apresentação e envio das inscrições}

15. As inscrições poderão ser realizadas a partir da publicação do Edital e se encerrarão em 12 de agosto de 2020. As etapas de recebimento, habilitação e avaliação das inscrições seguirão o cronograma a seguir:

Cronograma de avaliação 2018-2020*

\begin{tabular}{|l|l|l|l|l|l|l|l|}
\hline $\begin{array}{l}\text { Reuniões } \\
\text { de avalia- } \\
\text { ção }\end{array}$ & $\begin{array}{l}\text { Prazo para } \\
\text { recebi- } \\
\text { mento de } \\
\text { inscrições }\end{array}$ & $\begin{array}{l}\text { Lista } \\
\text { preliminar } \\
\text { de } \\
\text { inscrições } \\
\text { habilitadas }\end{array}$ & $\begin{array}{l}\text { Prazo para } \\
\text { envio de } \\
\text { recursos }\end{array}$ & $\begin{array}{l}\text { Lista final } \\
\text { de } \\
\text { inscrições } \\
\text { habilitadas }\end{array}$ & $\begin{array}{l}\text { Data da } \\
\text { reunião }\end{array}$ & $\begin{array}{l}\text { Lista } \\
\text { projetos } \\
\text { aprovados }\end{array}$ & $\begin{array}{l}\text { Prazo } \\
\text { envio } \\
\text { recur-sos } \\
\text { de }\end{array}$ \\
\hline $1^{\text {a }}$ & $13 / 08 / 18$ & $20 / 08 / 18$ & $24 / 08 / 18$ & $27 / 08 / 18$ & $18 / 09 / 18$ & $27 / 09 / 18$ & $03 / 10 / 18$ \\
\hline $2^{\text {a }}$ & $14 / 03 / 19$ & $21 / 03 / 19$ & $27 / 03 / 19$ & $28 / 03 / 19$ & $18 / 04 / 19$ & $30 / 04 / 19$ & $07 / 05 / 19$ \\
\hline $3^{\text {a }}$ & $14 / 08 / 19$ & $21 / 08 / 19$ & $27 / 08 / 19$ & $28 / 08 / 19$ & $18 / 09 / 19$ & $27 / 09 / 19$ & $03 / 10 / 19$ \\
\hline $4^{\text {a }}$ & $16 / 03 / 20$ & $23 / 03 / 20$ & $27 / 03 / 20$ & $30 / 03 / 20$ & $22 / 04 / 20$ & $04 / 05 / 20$ & $08 / 05 / 20$ \\
\hline $5^{a}$ & $12 / 08 / 20$ & $19 / 08 / 20$ & $25 / 08 / 20$ & $26 / 08 / 20$ & $17 / 09 / 20$ & $28 / 09 / 20$ & $02 / 10 / 20$ \\
\hline
\end{tabular}

* Datas prováveis

16. O número de reuniões poderá ser abreviado ou acrescido pelo Centro de Cooperação e Difusão da FBN, conforme disponibilidade orçamentária e/ou fluxo de inscrições recebidas no período.

17. Inscrições recebidas após os prazos indicados para cada reunião serão avaliadas nas reuniões posteriores.

18. As inscrições serão gratuitas, cabendo ao proponente, entretanto, o ônus da participação no processo seletivo, conforme descrição do item 54 deste Edital.

19. As editoras interessadas deverão enviar à FBN, no momento da inscrição, os seguintes documentos, digitalizados em PDF (por e-mail: translation@bn.gov.br) ou por via postal, conforme as especificidades de cada projeto (tradução/reedição ou publicação em países da CPLP):

a) Carta de apresentação do projeto, justificando a solicitação do apoio (em português, espanhol, francês ou inglês);

b) Formulários de inscrição totalmente preenchidos (digitados ou em letra legível), assinados pelo representante legal da editora (Anexo 1 e Anexo 2 ou Anexo 3); 
c) Cópia do contrato de cessão de direitos autorais estabelecido entre editora e autor(es) ou seus representantes legais, ou documento correspondente, em português, espanhol, francês ou inglês. Documentos em outros idiomas deverão ser acompanhados de ementa assinada pelas partes no contrato, em português, espanhol, francês ou inglês;

d) Cópia do contrato de tradução da obra em referência estabelecido entre a editora e o tradutor, mencionando obrigatoriamente o custo da tradução, em português, espanhol, francês ou inglês. Documentos em outros idiomas deverão ser acompanhados de ementa assinada pelas partes no contrato, em português, espanhol, francês ou inglês;

e) Anuência do(s) autor(es) ou de seus representantes legais com relação ao pedido, por meio de carta ou correio eletrônico;

f) Declaração do tradutor com referência ao valor acordado com a editora para tradução da obra em questão, por meio de carta ou correio eletrônico;

g) Documento de identidade do(s) autor(es) ou de seus representantes legais;

h) Cópia de registro comercial, estatuto ou contrato social em vigor da editora / instituição estrangeira;

i) Currículo do tradutor contratado (em português);

j) Catálogo recente das publicações da editora proponente;

k) Exemplar da obra, impresso ou em arquivo digital;

1) Projeto de distribuição e venda do livro a ser publicado, tiragem prevista, formas de divulgação da obra, com a indicação dos principais canais e pontos de venda, físicos e/ou virtuais, que serão utilizados, especialmente nos primeiros 6 (seis) meses após a publicação (em português, inglês ou espanhol). 19.1. Os itens descritos nas alíneas "g" a " $\mathrm{k}$ " poderão ser dispensados caso a FBN já os detenha em seus arquivos.

19.2. Inscrições por via postal devem ser encaminhadas para o endereço:

Fundação Biblioteca Nacional

Centro de Cooperação e Difusão

Programa de Apoio à Tradução e à

Publicação de Autores Brasileiros no Exterior 
Avenida Rio Branco, $219-4^{\circ}$ andar

20040-008 - Rio de Janeiro - RJ - Brasil.

19.3. Não serão aceitas inscrições por via postal recebidas após os prazos indicados no cronograma constante no item 15 deste Edital, independentemente da data de envio.

20. Não há número máximo de projetos inscritos por editora.

21. A editora proponente será a único responsável pela veracidade da proposta e dos documentos encaminhados, bem como da fidelidade da obra, isentando a FBN e o Ministério da Cultura de quaisquer responsabilidades civis ou penais por eventuais fraudes ou equívocos.

\section{Seção 7 - Etapa de habilitação}

22. Para a habilitação da inscrição será necessário o envio dos documentos e dos formulários, devidamente preenchidos, em conformidade com o item 19 deste Edital. 23. Compete ao Centro de Cooperação e Difusão/FBN (CCD/FBN) proceder ao exame de habilitação das inscrições e eventuais pedidos de reconsideração.

24. Será desconsiderada a inscrição apresentada com ausência de informações que possa prejudicar a análise.

25. Apenas as inscrições habilitadas serão submetidas à fase de avaliação e seleção, sendo inabilitados os projetos que não cumprirem os requisitos dispostos no item 19 deste Edital.

26. Após o término do prazo de recebimento de inscrições será divulgada em até 5 (cinco) dias úteis, no sítio eletrônico da Fundação Biblioteca Nacional (www.bn.gov.br), o resultado preliminar de projetos habilitados que conterá o nome do autor e do proponente e a razão do indeferimento se for o caso.

27. Caberá recurso da eventual inabilitação, a ser enviado no prazo de 4 (quatro) dias úteis, por meio de e-mail, a contar do dia subsequente da data de divulgação do resultado para o seguinte endereço: translation@bn.gov.br .

27.1. Durante o período de recurso, será aceito o envio de documentos cuja ausência na apresentação da inscrição tenha sido motivo de inabilitação. 
28. O resultado final da fase de habilitação será divulgado por meio de publicação no sítio eletrônico da Fundação Biblioteca Nacional (www.bn.gov.br).

\section{Seção 8 - Avaliação e seleção}

29. O processo seletivo das inscrições será realizado por uma Comissão Avaliadora, designada pelo Presidente da FBN por meio de decisão executiva, constituída por:

a) Dois representantes da FBN, destacados do Centro de Cooperação e Difusão e do Centro de Pesquisa e Editoração. O representante do Centro de Cooperação e Difusão presidirá a Comissão.

b) Dois representantes do Ministério da Cultura ou de suas entidades vinculadas;

c) Um representante do Departamento Cultural do Ministério das Relações Exteriores;

d) Um especialista em literatura e/ou tradução, preferencialmente profissional da área e/ou professor universitário.

29.1. Compete aos integrantes da Comissão Avaliadora:

a) Analisar as inscriçõos em observância aos critérios previstos neste Edital;

b) Analisar os recursos da etapa de avaliação e seleção no prazo máximo de 5 (cinco) dias úteis, a contar da data do recebimento da interposição do pedido na sua unidade;

29.2. Os membros da Comissão Avaliadora e respectivos suplentes ficam impedidos de avaliar inscrições nas quais:

a) Tenham participado como colaborador na elaboração da inscrição, tenham feito parte da editora/instituição proponente nos últimos dois anos, ou se tais situações tenham ocorrido com seu respectivo cônjuge, companheiro ou parente em linha reta, colateral ou por afinidade, até o terceiro grau; ou

b) Estejam litigando judicial ou administrativamente com a editora/instituição proponente, ou com seu respectivo cônjuge ou companheiro.

29.3. Compete ao Presidente da Comissão Avaliadora, sem prejuízo das atribuições pertinentes aos demais integrantes: 
a) Coordenar os trabalhos da Comissão;

b) Presidir as reuniões da Comissão; e

c) Emitir voto de qualidade, quando necessário.

30. A Comissão Avaliadora adotará os seguintes critérios de seleção:

\begin{tabular}{|c|c|c|c|c|}
\hline Critério & Fatores de consideração principais & Peso & Pontos & $\begin{array}{l}\text { Nota } \\
\text { máxima }\end{array}$ \\
\hline $\begin{array}{l}\text { a) Relevância, } \\
\text { relativa, da } \\
\text { publicação da obra } \\
\text { para a promoção e } \\
\begin{array}{ll}\text { a divulgação da } \\
\text { cultura e } & \text { da } \\
\text { literatura } & \\
\text { brasileira } & \\
\text { exterior. }\end{array}\end{array}$ & $\begin{array}{l}\text { - Representatividade da obra no campo } \\
\text { da literatura e produção intelectual } \\
\text { brasileira; } \\
\text { - Aspecto de diversidade que a tradução/ } \\
\text { publicação da obra é capaz de agregar ao } \\
\text { quadro geral de obras e autores } \\
\text { brasileiros já traduzidos e publicados no } \\
\text { exterior; } \\
\text { - Aspecto de diversidade que a tradução/ } \\
\text { publicação da obra é capaz de agregar ao } \\
\text { quadro geral de gêneros literários já } \\
\text { contemplados pelo Programa de Apoio à } \\
\text { Tradução e à Publicação de Autores } \\
\text { Brasileiros no Exterior. }\end{array}$ & 2 & 0 a 5 & 10 \\
\hline 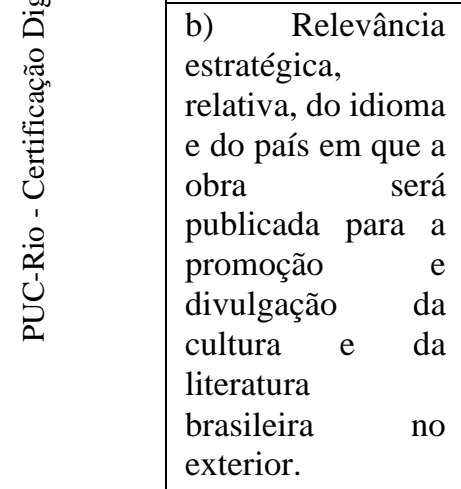 & $\begin{array}{l}\text { - Nível de circulação global que a } \\
\text { publicação da obra em determinado } \\
\text { idioma é capaz de proporcionar. } \\
\text { - Aspecto de diversidade que a tradução/ } \\
\text { publicação da obra é capaz de agregar ao } \\
\text { quadro geral das línguas e países em que } \\
\text { a literatura e produção intelectual } \\
\text { brasileira já se encontram representadas. }\end{array}$ & 1 & 0 a 5 & 5 \\
\hline $\begin{array}{l}\text { c) Relevância da } \\
\text { editora proponente } \\
\text { no que diz respeito } \\
\text { ao catálogo, } \\
\text { projeto e meios de } \\
\text { promoção } \\
\text { distribuição da } \\
\text { obra publicada. }\end{array}$ & $\begin{array}{l}\text { - Histórico de atuação da editora; } \\
\text { - Condições da editora para a efetiva } \\
\text { divulgação da obra a ser publicada no } \\
\text { exterior. }\end{array}$ & 1 & 0 a 5 & 5 \\
\hline $\begin{array}{l}\text { d) Currículo do } \\
\text { tradutor. }\end{array}$ & $\begin{array}{l}\text { - Experiência do profissional na tradução } \\
\text { direta de literatura em língua portuguesa } \\
\text { para o idioma em questão; }\end{array}$ & 1 & 0 a 5 & 5 \\
\hline
\end{tabular}




\begin{tabular}{|l|l|l|r|r|}
\hline & $\begin{array}{l}- \text { Admissibilidade de profissionais } \\
\text { iniciantes, tendo em vista o incentivo à } \\
\text { formação de novos tradutores. }\end{array}$ & & & \\
\hline & & & Total & 25 \\
\hline
\end{tabular}

30.1. As notas mínima e máxima para os critérios previstos serão, respectivamente, 0 e 5 (zero a cinco);

30.2. Em caso de empate prevalecerá o projeto com a maior nota no critério "a"; persistindo o empate, no critério "b"; persistindo o empate, no critério "c", persistindo o empate, no critério " $\mathrm{d}$ ".

30.3. Em caso de persistência do empate, será considerada a proposta com o menor custo para atendimento

30.4. A pontuação mínima para classificação será de 17,5 (dezessete vírgula cinco). Projetos com pontuação inferior a 17,5 serão automaticamente desclassificados.

30.5. As inscrições encaminhadas por editoras da CPLP serão avaliadas segundo os critérios "a" a “c”, sendo 14 (quatorze) a pontuação mínima para classificação.

31. A Comissão adotará como critério para estabelecimento do valor do apoio, conforme a especificidade de cada projeto:

a) Custo estimado da tradução, tendo em conta os custos médios aplicados para a língua de destino;

b) Custo estimado para publicação;

32. Caberá à Comissão Avaliadora entregar ao Centro de Cooperação e Difusão:

a) uma lista de projetos selecionados;

b) uma lista de projetos classificados não-selecionados.

32.1. Ambas as listas deverão conter:

I - Nome do projeto;

II - País de origem;

III - Nota obtida na avaliação;

IV - Valor do apoio concedido;

V - Nome dos membros da Comissão. 
33. Os projetos classificados não-selecionados poderão ser contemplados posteriormente em caso de disponibilidade de recursos, a critério da unidade gestora da seleção pública e respeitada a prioridade aos selecionados, a ordem decrescente de pontuação e o prazo de vigência da seleção pública.

34. O resultado final da seleção será comunicado diretamente à editora contemplada por correio eletrônico, em até 7 (sete) dias úteis após as reuniões de avaliação, e ficará disponível no sítio eletrônico da FBN, bem como será publicado no Diário Oficial da União.

35. Caberá pedido de reconsideração da lista de projetos selecionados e dos valores concedidos, a ser enviado no prazo de 4 (quatro) dias úteis, por meio de correio eletrônico e formulário específico (Anexo 4), a contar do dia subsequente da data de divulgação do resultado, para translation@bn.gov.br.

35.1. Os pedidos de reconsideração serão analisados pelo Centro de Cooperação

e Difusão em concordância com os demais membros da Comissão Avaliadora num prazo de 5 (cinco) dias úteis.

\section{Seção 9 - Concessão}

36. A formalização da concessão do apoio será objeto de Termo de Compromisso redigido em língua portuguesa, firmado pelo responsável legal da editora e pelo Presidente da FBN.

37. O respectivo Termo de Compromisso será enviado à editora para assinatura e devolução à FBN.

38. Os apoios aprovados serão pagos à editora contemplada em duas parcelas, da seguinte forma:

a) $1^{\mathrm{a}}$ parcela: $50 \%$ do apoio, após assinatura do Termo de Compromisso pelas duas partes.

b) $2^{\text {a }}$ parcela: $50 \%$ do apoio, após o recebimento, pela FBN, de 5 (cinco) exemplares da obra publicada pela editora ou disponibilização da obra publicada em formato digital, nos casos de publicação apenas nesse formato. 
38.1. São de inteira responsabilidade da editora a atualização dos dados cadastrais e bancários.

39. Após a divulgação do resultado da seleção, os proponentes selecionados deverão encaminhar no prazo de 5 (cinco) dias úteis os seguintes itens, a título de documentação complementar:

a) Dados bancários para pagamento do apoio, em nome da editora ou de seu representante legal;

b) Documento de identidade do representante legal da editora.

\section{Seção 10 - Obrigações da editora}

40. A editora contemplada compromete-se a entregar 6 (seis) exemplares da obra publicada em até 24 (vinte e quatro) meses após a assinatura do Termo de Compromisso.

a) Cinco exemplares no escritório do Centro de Cooperação e Difusão/FBN;

b) Um exemplar na embaixada ou representação oficial do Brasil localizada no país da Editora.

40.1. No caso de apoio concedido para tradução e/ou publicação de livros digitais, a editora compromete-se a disponibilizar o acesso à obra publicada. 40.2. O prazo de entrega poderá ser prorrogado por meio de Termo Aditivo pelo período de até 12 (doze) meses, conforme pedido e justificativa da Editora desde que remetidos ao Centro de Cooperação e Difusão/FBN antes do término do prazo previsto no Termo de Compromisso.

40.2.1. Em caráter excepcional e em conformidade com o item 56 deste Edital, a incidência de fatos supervenientes, devidamente comprovados pela Editora, poderá ensejar uma revisão de prazos já estabelecidos.

41. A editora compromete-se a inserir a seguinte referência na página de créditos da obra publicada, na língua da tradução e em português:

"Obra publicada com o apoio do Ministério da Cultura do Brasil | Fundação Biblioteca Nacional.” 
41.1. A referência acima especificada deverá ser acompanhada do logotipo da FBN, conforme imagem abaixo e suas especificações:

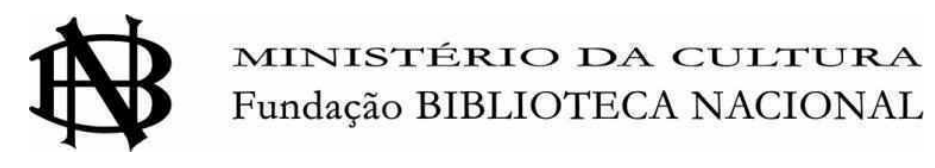

Medidas mínimas para aplicação do logotipo na página de créditos:

a) Altura: $0,71 \mathrm{~cm}$

b) Largura: $4,00 \mathrm{~cm}$

c) Definição: 300 dpi

Especificação das cores:

a) Preto/Black 100\% (K100\%); ou

b) Pantone $456 \mathrm{C}$; ou

c) Pantone $201 \mathrm{C}$.

41.2. O logotipo e a referência ao apoio concedido poderão ser inseridos em local diferente da página de créditos mediante aprovação prévia da FBN.

42. Antes da impressão da obra, a editora deverá enviar à FBN, para aprovação, prova impressa da página de créditos.

42.1. Em casos excepcionais, mediante a análise e aprovação da FBN, a editora poderá incluir o logotipo e a referência no livro após a publicação da obra.

43. No caso de edições apenas em forma de livro impresso, a editora compromete-se a publicar, no mínimo, 1.000 (mil) exemplares da obra, em primeira edição, e 500 (quinhentos) exemplares no caso de reedição.

43.1 Projetos de publicação com tiragem inferior a 1.000 (mil) exemplares, em primeira edição, serão objeto de análise especial da Comissão.

44. A editora se responsabiliza pela correta apresentação da documentação relativa ao Termo de Compromisso e às autorizações decorrentes aos direitos de autor e conexos presentes na obra, sem a qual o mesmo não poderá ser formalizado.

44.1 A editora deverá: 
a) Comunicar imediatamente à FBN qualquer fato grave que leve à descontinuidade do projeto que possa vir a modificar ou interromper a execução do Termo de Compromisso que formaliza a concessão do apoio;

b) Comunicar imediatamente à FBN eventual alteração do representante da editora e do(a) funcionário(a) responsável pelo projeto;

c) Devolver à FBN eventuais valores recebidos indevidamente;

d) Encaminhar à FBN um recibo assinado pelo(s) tradutor(es) contratado(s), comprovando o pagamento dos honorários;

e) Encaminhar à FBN um comprovante de impressão da tiragem mínima estabelecida conforme a proposta apresentada.

45. Qualquer descumprimento do Termo de Compromisso ensejará penalidades a serem aplicadas pela FBN.

\section{Seção 11 - Penalidades}

46. Caso a editora não entregue a obra nos termos e prazos previstos neste Edital e definidos no Termo de Compromisso, será obrigada a devolver o valor já recebido, com incidência de correção monetária e juros de mora.

47. O descumprimento de cláusulas deste Edital ou do Termo de Compromisso firmado entre a Editora e a FBN poderá implicar penalidades ou restrições para futuras inscrições de acordo com os seguintes critérios:

a) Descumprimento de prazo para entrega da obra uma vez esgotadas as possibilidades de readequação do cronograma de publicação: devolução do valor concedido com incidência de correção monetária e juros de mora, segundo os requisitos legais, e a impossibilidade de apresentar projetos ao Programa por até 3 (três) anos, segundo avaliação da Coordenadoria-Geral do Centro de Cooperação e Difusão.

b) Desistência do projeto após o pagamento da $1^{\mathrm{a}}$. parcela: devolução do valor concedido, com incidência de correção monetária e juros de mora, segundo os requisitos legais, e a impossibilidade de apresentar projetos ao Programa por 
até 3 (três) anos, segundo avaliação da Coordenadoria-Geral do Centro de Cooperação e Difusão.

c) Não-pagamento dos serviços de tradução contratados para o projeto: exclusão da editora para novos projetos e financiamentos da FBN.

d) Inobservância do Acordo Ortográfico da Língua Portuguesa, em conformidade com os termos do Item 11 deste Edital: cancelamento do apoio e devolução do valor da $1^{\text {a }}$ parcela, com incidência de correção monetária e juros de mora, segundo os requisitos legais.

\section{Seção 12 - Acompanhamento e avaliação}

48. A editora compromete-se a informar, durante o período contratual, dados do cronograma de tradução; das etapas da produção e da previsão de lançamento sempre que for demandada pela FBN.

49. Seis meses após o lançamento do livro, ainda que ultrapassado o período contratual regular, a editora poderá ser solicitada a apresentar à FBN um relatório de desenvolvimento do plano de distribuição e divulgação da obra.

\section{Seção 13 - Disposições finais}

50. Este Edital estará disponível no sítio eletrônico da FBN (www.bn.gov.br) e do Ministério da Cultura do Brasil (www.cultura.gov.br) e será publicado no Diário Oficial da União.

51. Para esclarecimento de dúvidas, o interessado deverá entrar em contato por telefone +55 21 2220-2796 ou por e-mail: translation@bn.gov.br

52. Os materiais encaminhados pelas editoras não serão devolvidos, cabendo à FBN a decisão sobre seu arquivamento ou destruição.

53. A FBN se reserva o direito de publicar trechos das obras traduzidas com apoio deste Edital em publicações para fins de promoção da literatura brasileira e divulgação do Programa de Apoio à Tradução e à Publicação de Autores Brasileiros no Exterior em concordância com os autores e tradutores. 
54. O ônus da participação no processo seletivo, incluídas as despesas com cópias, correio e emissão de documentos é de exclusiva responsabilidade do proponente.

55. O ato de inscrição pressupõe que a editora manifesta plena e irretratável anuência com relação a todos os itens do presente Edital.

56. Os casos omissos serão deliberados pela Presidência da FBN.

57. Eventuais irregularidades relacionadas aos requisitos de participação, constatadas a qualquer tempo, implicarão a inabilitação da inscrição.

58. Os projetos inscritos, se lecionados ou não, passarão a fazer parte do cadastro da FBN para fins de pesquisa, documentação e mapeamento da produção cultural brasileira.

\section{Helena Severo}

Presidente

Fundação Biblioteca Nacional 


\section{Programa de Apoio à Tradução e à Publicação de Autores Brasileiros no Exterior}

\section{Anexo I - Formulário de inscrição}

\section{Dados da editora}

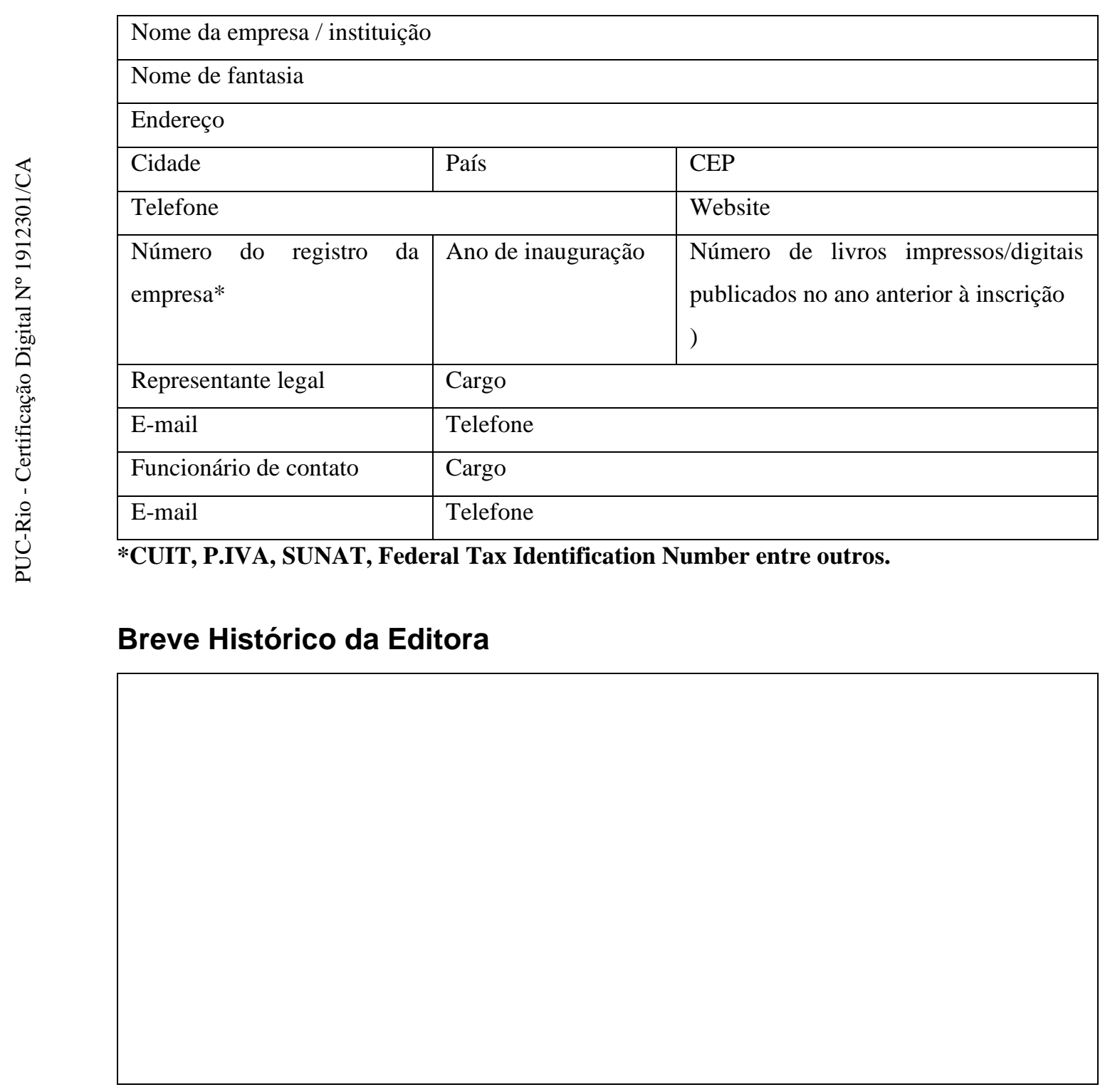




\section{Dados da obra}

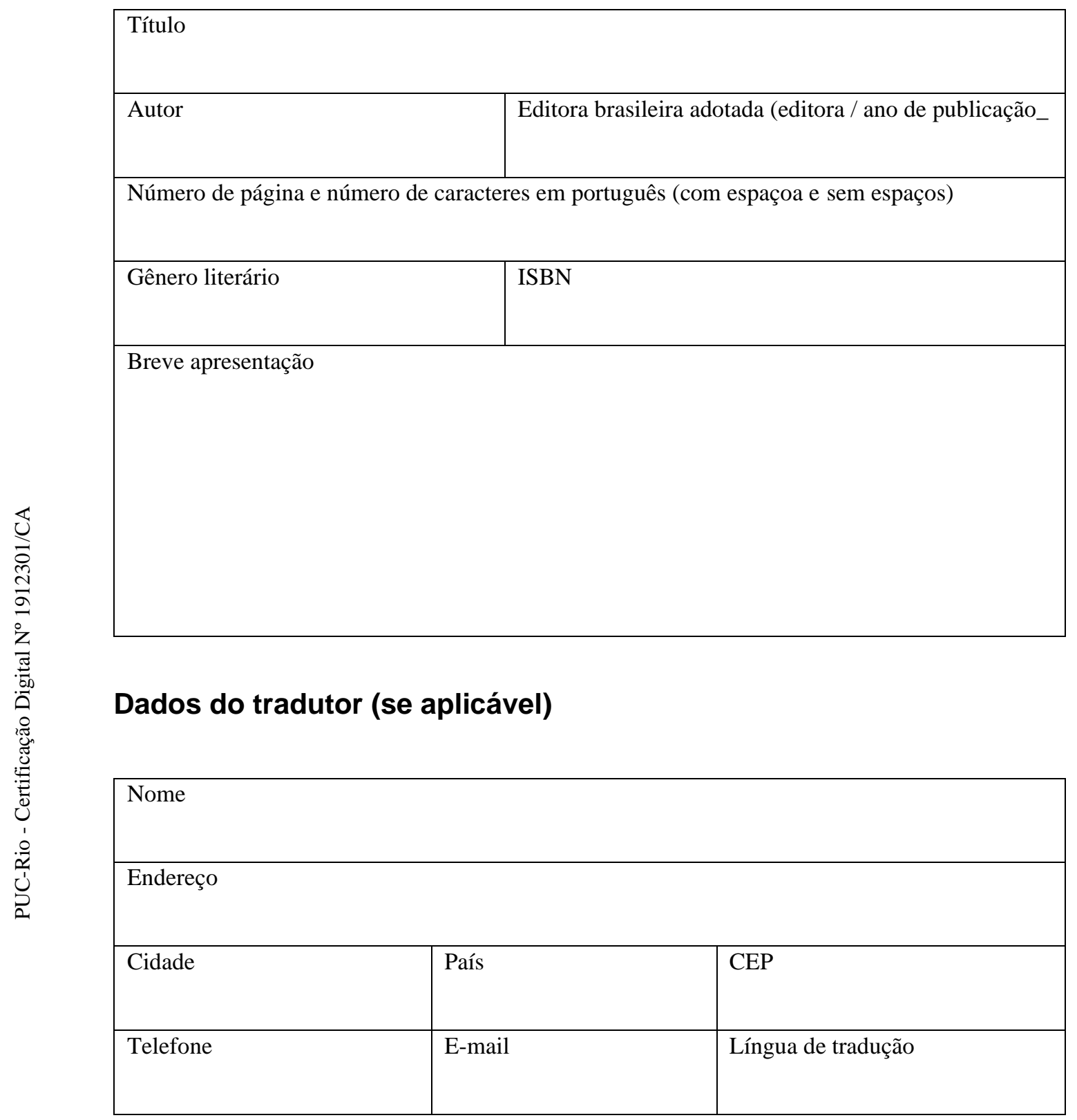




\section{Dados da publicação}

\section{(dados editoriais sobre o projeto de tradução e publicação)}

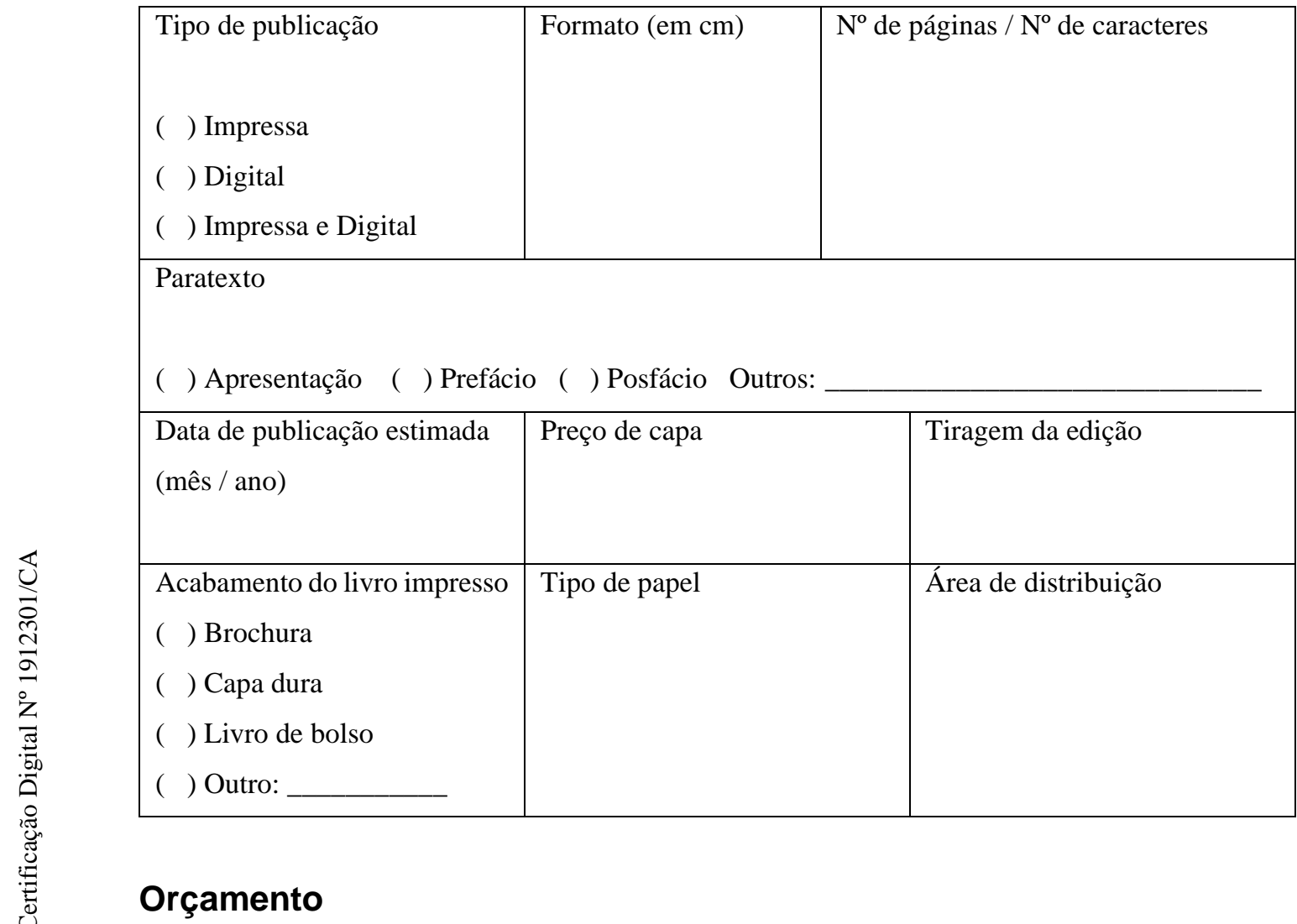

\begin{tabular}{|l|l|}
\hline $\begin{array}{l}\text { Custo da tradução em dólares (USD\$) } \\
\text { (informar a maneira como foi calculado: por } \\
\text { lauda, por palavra etc.) }\end{array}$ & Valor solicitado à FBN, em dólares (USD\$) \\
\hline $\begin{array}{l}\text { Outros custos, em dólares (USD\$) } \\
\text { (edição, revisão e impressão) }\end{array}$ & Valor solicitado à FBN, em dólares \\
\hline A & \\
\hline
\end{tabular}

A editora solicitante ou o tradutor receberam bolsas/subsídios/incentivos de outras instituições, públicas ou privadas, brasileiras ou estrangeiras, para a tradução/publicação da obra em questão?

( ) Não. ( ) Sim. Instituição e valor em dólares (USD\$): 


\section{Informações adicionais}

Como conheceu o Programa de Apoio à Tradução e Publicação de Autores Brasileiros no Exterior?

( ) Agentes literários

() Autores

( ) Tradutores

( ) Feira de Livro e/ou evento literário. Qual?

( ) Outros. Especifique: 


\section{Declaração}

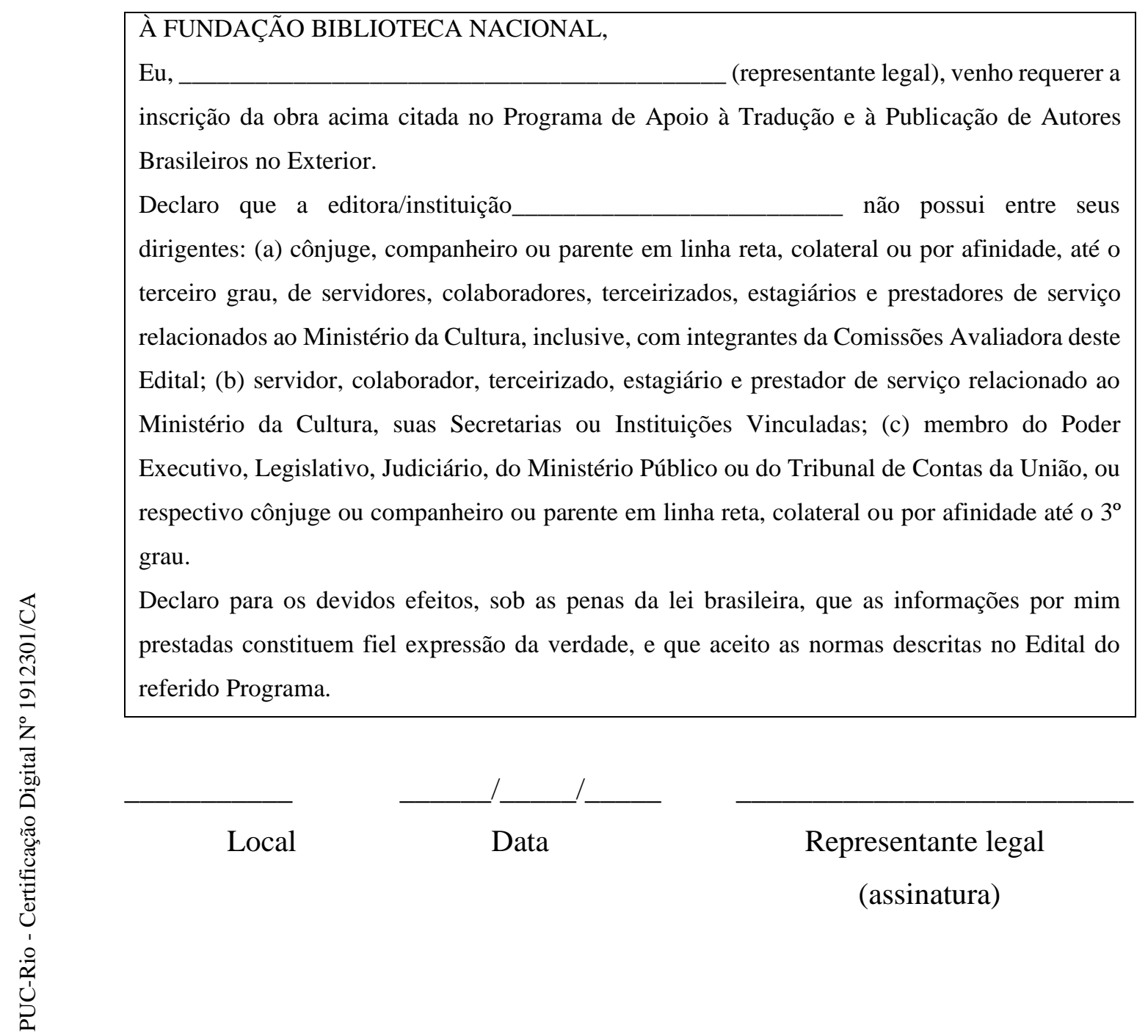




\section{Anexo 2 - Comprovação da Cessão dos Direitos Autorais Patrimoniais de Obra}

Declaro, na qualidade de representante legal da Editora

situada em , ser ela titular dos direitos autorais patrimoniais, para fins de tradução e posterior publicação em língua da obra original publicada em português no Brasil, com o título:

de Autoria

de , de acordo com o instrumento legal

efetivado com Autor e/ou seu representante legal, cuja cópia segue em anexo.

Declaro, ainda, que a mesma possui contrato de tradução, cuja cópia segue em anexo, devidamente legalizado com o $\operatorname{Sr}(a)$ : , que executará o serviço de tradução, de cujos direitos autorais patrimoniais é titular.
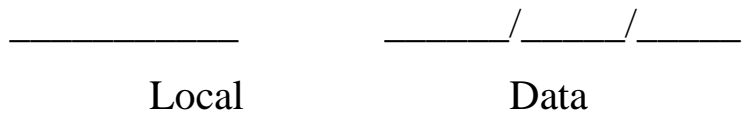

Representante legal (assinatura) 


\section{Anexo 3 - Comprovação da Cessão dos Direitos Autorais Patrimoniais de Obra}

(Para Editoras de Países de Língua Portuguesa)

Declaro, na qualidade de representante legal da Editora

situada em , ser ela titular dos direitos autorais patrimoniais, para fins de publicação em , país membro da

Comunidade dos Países de Língua Portuguesa da obra original publicada em português no Brasil, com

o título: , de Autoria de , de acordo com o instrumento legal efetivado com Autor e/ou seu representante legal, cuja cópia segue em anexo. Declaro, ainda, que a mesma possui contrato de cessão de direitos autorais, cuja cópia segue em anexo, devidamente legalizado com o $\operatorname{Sr}(\mathrm{a})$ :
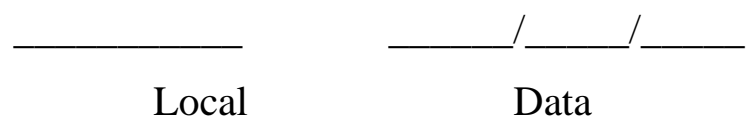

Representante legal (assinatura) 


\section{Anexo 4 - Formulário de Recurso}

\begin{tabular}{|l|}
\hline Editora: \\
\hline Obra / Autor(a): \\
\hline Apresentação de recurso ao resultado final de seleção: \\
\\
\\
\\
\\
\hline Data: \\
\hline
\end{tabular}




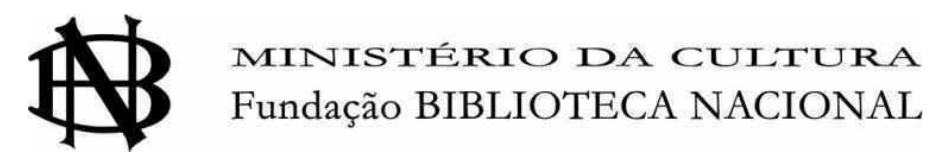

\section{Notice № 1 - 2018 | Support Program For The Translation And Publication of Brazilian Authors 2018-2020}

The Brazilian National Library Foundation announces that it will offer grants to foreign publishing houses that wish to translate, publish, and distribute works by Brazilian authors abroad that have been previously published in Brazil. This procedure, authorized by Executive Decision No. 25 FBN, of 21/06/2018, will be governed by the following Notice and by Ministry of Culture Directive No. 29/2009, and, supplementarily, by Law No. 8666/93.

\section{Section 1 - Aim}

1. The Support Program for the Translation and Publication of Brazilian Authors, created by the Brazilian National Library Foundation (FBN), under the Brazilian Ministry of Culture, aims to spread Brazilian culture and literature abroad by granting financial support for translation and publication of works by Brazilian authors.

2. The Program is designed for foreign publishers that wish to translate into any language, publish, and distribute abroad works by Brazilian authors, in book or digital form, that have been previously published in Portuguese in Brazil.

2.1 For the purposes of the Program, either Brazilian nationals or naturalized Brazilian citizens will be considered as authors. Authors who do not meet these requirements will be the object of special scrutiny by the evaluation committee. 2.2 The Program is also open to publishers from the Community of Portuguese Language Speaking Countries (CPLP) that wish to publish and distribute works by Brazilian authors in their countries.

3. The Program will provide support for proposals in literature and the humanities, especially in the following genres: novels, short stories, poetry, chronicle, children's 
literature, graphic novels, theater, reference works, literary essays, social science essays, popular science essays and anthologies of poems and short stories, either in whole or in part.

3.1 In order to enhance the diffusion of Brazilian literature and intellectual production, projects concerning essay, short story or poem collections may include texts previously unpublished in Brazil, upon discretion of the evaluation committee

4. Grants may be awarded to projects concerning:

a) First translations;

b) Second translations;

c) Reissues of sold out and out of print titles for at least three years;

d) With regard to publishers from the Community of Portuguese Language Speaking Countries (CPLP), first editions or reissues of sold out and out of print titles for at least three years.

4.1 The main goal of the support is to fund, in full or in part, foreign publisher's translation expenses related to works by Brazilian authors. Editing and printing expenses will be the object of special scrutiny by the evaluation committee.

4.2 The support given to translation projects of graphic novels, comics and children's and youth books may include both translation costs and editing and printing costs.

4.3 The support given to projects from Community of Portuguese Language Speaking Countries (CPLP) publishers will include editing and printing costs.

5. Special notices may be arranged in accordance with FBN's interests regarding, for example, authors in the public domain and specific languages and genres.

\section{Section 2 - Notice's Validity}

6. This Notice will be valid for a period of 24 (twenty-four months), as of the date of publication in the official journal of Brazilian government (Diário Oficial da União), and may be extended, if necessary, for a period of up to twelve (12) months. 


\section{Section 3- Available Funds}

7. In order to meet the objectives of this Notice, $R \$ 30,000.00$ (thirty thousand Brazilian reais) are allocated for 2018, based on Action 20ZF, Promoting and Fostering Brazilian Culture of the Annual Budgetary Law (LAO) and/or Brazilian National Culture Fund (FNC) or upon financial and budgetary availability or of another entity or public body in partnership with FBN.

7.1 Resource allocation for subsequent years will be contingent upon financial and budgetary availability, in accordance with the caption.

\section{Section 4 - Eligibility}

8. Foreign publishers duly established in their countries of origin may participate in the Program.

9. Proposals that have not been approved under previous FBN Notices may be resubmitted, provided they follow the guidelines as defined in this Notice.

10. Applications from publishers with pending commitments with FBN or those that have faced penalties for not complying with their obligations will not be accepted, according to the cases defined in Section 11 of this Notice.

11. Publishers from CPLP countries must observe the Portuguese Language Orthographic Agreement of 1990 in the editions supported by the Program, with the exception of those coming from countries where the Agreement has not come into effect yet.

12. Applications presented by publishers whose directors fall into the categories below will not be accepted:

a) Spouse, partner or relative in a direct line, collateral or by affinity up to the third degree, of public servants, associates, outsourced employees, trainees and service providers related to the Ministry of Culture, including members of the Evaluation Committee of this Program;

b) Public servant, associate, outsourced employee, trainee and service provider related to the Ministry of Culture, its Secretariats or Related Institutions; 
c) Member of the Executive, Legislative, Judiciary, Prosecution Service of the Union or the Federal Court of Accounts, or their spouse or partner or relative in a straight line, collateral or by affinity up to the third degree.

12.1 In order to make this provision effective, the applicant must fill out the corresponding declaration on Annex 1 of this Notice.

\section{Section 5 - Grants}

13. FBN will award grants of US\$ $1,000.00$ (one thousand US dollars) to US $\$ 6,000.00$ (six thousand US dollars) for each translation or publication project and up to US\$ 3,000.00 (three thousand US dollars) for each reissue project, in accordance with item 4 of this Notice.

13.1 The value of each grant will be based on the consideration of the translation expenses in particular and, exceptionally, editing, revising and printing expenses.

13.2 The support is of a supplementary nature considering that the publisher is fully responsible for the translation / publication project.

13.3 In respect to applicants from Portuguese speaking countries, the amount of each grant will take into consideration editing, revising and printing costs.

14. The awarding of grants is contingent upon the availability of budgetary and financial resources and, selection is at the discretion of the FBN and the Brazilian Ministry of Culture

\section{Section 6 - Applications}

15. Applications are open from the publication of this Notice until August 12th, 2020*, according to the following schedule:

\begin{tabular}{|l|l|l|l|l|l|l|l|}
\multicolumn{1}{|c|}{ Evaluation Schedule 2018-2020* $^{\text {Evaluation }} \begin{array}{l}\text { Deadline } \\
\text { meeting } \\
\text { application }\end{array}$} & $\begin{array}{l}\text { Preliminary } \\
\text { list of eligible } \\
\text { applications }\end{array}$ & $\begin{array}{l}\text { Deadline for re- } \\
\text { consideration } \\
\text { requests }\end{array}$ & $\begin{array}{l}\text { Final list } \\
\text { of } \\
\text { eligible } \\
\text { applica- } \\
\text { tions }\end{array}$ & $\begin{array}{l}\text { Date of } \\
\text { evalua- } \\
\text { tion } \\
\text { meeting }\end{array}$ & $\begin{array}{l}\text { Selec- } \\
\text { tion } \\
\text { result }\end{array}$ & $\begin{array}{l}\text { Deadline } \\
\text { for re- } \\
\text { Considera- } \\
\text { tion } \\
\text { requests }\end{array}$ \\
\hline $1^{\text {a }}$ & $13 / 08 / 18$ & $20 / 08 / 18$ & $24 / 08 / 18$ & $27 / 08 / 18$ & $18 / 09 / 18$ & $27 / 09 / 18$ & $03 / 10 / 18$ \\
\hline
\end{tabular}




\begin{tabular}{|l|l|l|l|l|l|l|l|}
\hline $2^{\mathrm{a}}$ & $14 / 03 / 19$ & $21 / 03 / 19$ & $27 / 03 / 19$ & $28 / 03 / 19$ & $18 / 04 / 19$ & $30 / 04 / 19$ & $07 / 05 / 19$ \\
\hline $3^{\mathrm{a}}$ & $14 / 08 / 19$ & $21 / 08 / 19$ & $27 / 08 / 19$ & $28 / 08 / 19$ & $18 / 09 / 19$ & $27 / 09 / 19$ & $03 / 10 / 19$ \\
\hline $4^{\mathrm{a}}$ & $16 / 03 / 20$ & $23 / 03 / 20$ & $27 / 03 / 20$ & $30 / 03 / 20$ & $22 / 04 / 20$ & $04 / 05 / 20$ & $08 / 05 / 20$ \\
\hline $5^{\mathrm{a}}$ & $12 / 08 / 20$ & $19 / 08 / 20$ & $25 / 08 / 20$ & $26 / 08 / 20$ & $17 / 09 / 20$ & $28 / 09 / 20$ & $02 / 10 / 20$ \\
\hline
\end{tabular}

16. The number of meetings may be reduced or increased according to the amount of applications received as well as financial and budgetary availability.

17. Should an application arrive after the deadline for each meeting, it will be evaluated at the following date.

18. Applications are free of charge. The costs incurred to participate in the selection are the sole responsibility of the applicant, as described in item 54 of this Notice.

19. In order to apply, publishers must send to FBN the following documents by email, in PDF, [translation@bn.gov.br or by regular mail, according to the particularities of each project (translation/reissue or publication in CPLP countries):

a) Letter, in Portuguese, Spanish, English or French, requesting registration in the Program and justifying the grant request;

b) Completed application forms (typed or legibly printed), signed by the legal representative of the publisher (Annexes 1 and 2 or 3 )

c) Copy of the copyright contract between the author(s) or legal representatives and the publisher, or corresponding document, in Portuguese, English, French or Spanish. Documents in other languages than these must be submitted with a summary in Portuguese, English, French or Spanish, signed by the same parties.

d) Copy of contract between the publisher and the translator obligatorily mentioning the cost of translation, in Portuguese, English, French or Spanish. Documents in other languages than these must be submitted with a summary in Portuguese, English, French or Spanish, signed by the same parties;

e) Author's or legal representative's consent to the request, by letter or e-mail;

f) Translator's declaration with respect to the honorarium settled with the publisher, by letter or e-mail;

g) Author's or legal representative's identity document;

h) Publisher's legal registration, statute or valid social contract;

i) Translator's resumé in Portuguese;

j) Publisher 's recent catalog;

k) A copy (print or digital) of the work to be translated; 
1) Distribution and sales projections of the book to be published, expected run, and advertising methods, indicating the main channels and physical and/or online points of sale that will be used, especially in the first 6 (six) months following publication (in Portuguese, English or Spanish).

19.1 Documents "g" to "k" may be exemptible if FBN already holds them in their archive.

19.2 Applications by regular mail must be sent to:

Fundação Biblioteca Nacional

Centro de Cooperação e Difusão

Programa de Apoio à Tradução e à

Publicação de Autores Brasileiros no Exterior

Avenida Rio Branco, $219-4^{\circ}$ andar

20040-008 - Rio de Janeiro - RJ - Brasil.

19.3 Applications by regular mail will only be accepted until the deadlines detailed above regardless of the posting date.

20. There is no limit to the number of project registrations per publisher

21. The applicant is uniquely responsible for the truthfulness and accuracy of their proposal and documents, thus, exempting both the National Library of Brazil and its Ministry of Culture from any civil or criminal responsibility concerning eventual errors or equivocations.

\section{Section 7 - Eligibility Stage}

22. For any application to be considered, a fully completed application package needs to be included in accordance with item 19.

23. The Center for Cooperation and Diffusion (Centro de Cooperação e Difusão - CCD) at the National Library will assess the eligibility of the applications as well as any appeals.

24. If an application is incomplete, thus, preventing the assessors from analyzing it, it will be excluded. 
25. Only the applications deemed eligible will proceed to the evaluation round. The applications that do not comply with item 19 will not be considered eligible.

26. Within 5 (five) business days after the application deadline, the preliminary results of the application's eligibility assessment will be announced in a list containing the name of the author and of the applicant. Should an application be deemed ineligible, the reason for ineligibility will also be included in the list.

27. In case of ineligible applications, the applicant will be able to appeal by e-mail within 4 (four) business days from the date of the publication of results at translation@bn.gov.br.

27.1 During this period, the applicant may present required documents that were not previously included in the application package

28. The final result of the eligibility stage will be announced on the National Library website (www.bn.gov.br).

\section{Section 8 - Evaluation and Selection}

29. The selection process will be carried out by an Evaluation Committee appointed by the National Library's president and constituted by the following members:

a) Two National Library representatives chosen from the Centre for Cooperation and Diffusion and the Centre for Publishing and Research. The representative from Centre for Cooperation and Diffusion will preside over the committee.

b) Two representatives from the Ministry of Culture or a public entity linked to it;

c) A representative from Ministry of External Relations' Cultural Department;

d) An expert in Literature and/or Translation, preferably a professional in the field and/or a university teacher.

29.1 It is incumbent on the members of the Evaluation Committee:

a) Assess the applications in compliance with the criteria set forth in this Notice;

b) Assess the appeals related to the evaluation and selection stage within a maximum period of five (5) business days. 
29.2 The members of the Evaluation Committee and their respective substitutes are prevented from evaluating applications in which:

a) They have participated as collaborators in the preparation of the application, have been part of the applicant publisher / institution in the last two years, or if such situations have occurred with their respective spouse, partner or relative in a direct line, collateral or by affinity, until the third degree; or

b) They are litigating judicially or administratively with the applicant publisher / institution, or with their respective spouse or partner

29.3 It is incumbent on the Chairman of the Evaluation Committee, without prejudice to the attributions pertinent to the other members:

a) To coordinate the work of the committee;

b) To preside over the evaluation meetings; and

c) To exercise a casting vote, when necessary.

30. The committee will adopt the following selection criteria:

\begin{tabular}{|c|c|c|c|c|}
\hline Criteria & Key Factors & Weight & Points & $\begin{array}{l}\text { Maximum } \\
\text { Score }\end{array}$ \\
\hline $\begin{array}{l}\text { a) The relative } \\
\text { importance of the } \\
\text { work's publication } \\
\text { to advancing and } \\
\text { spreading Brazilian } \\
\text { literature and } \\
\text { culture abroad; }\end{array}$ & $\begin{array}{l}\text { - Representativeness in the field of } \\
\text { Brazilian literature and intellectual } \\
\text { production; } \\
\text { - Diversity aspect brought to the } \\
\text { panorama of Brazilian authors and } \\
\text { works translated and published } \\
\text { abroad. } \\
\text { - Diversity aspect brought to the } \\
\text { panorama of literary genres usually } \\
\text { funded by the Support Program for the } \\
\text { Translation and Publication of } \\
\text { Brazilian Authors Abroad. }\end{array}$ & 2 & 0 to 5 & 10 \\
\hline $\begin{array}{l}\text { b) The relative } \\
\text { strategic } \\
\text { importance of the } \\
\text { language and } \\
\text { country in which } \\
\text { the work will be } \\
\text { published to } \\
\text { advancing and } \\
\text { spreading Brazilian } \\
\text { literature and } \\
\text { culture abroad. }\end{array}$ & $\begin{array}{l}\text { - Level of global circulation that the } \\
\text { work's publication in a specific } \\
\text { language may achieve. } \\
\text { - Diversity aspect brought to the } \\
\text { panorama of languages and countries } \\
\text { in which Brazilian literature and } \\
\text { intellectual production have been } \\
\text { published. }\end{array}$ & 1 & 0 to 5 & 5 \\
\hline
\end{tabular}




\begin{tabular}{|c|c|c|c|c|}
\hline $\begin{array}{l}\text { c) Publisher's } \\
\text { consistency with } \\
\text { respect to its } \\
\text { catalogue, } \\
\text { application project } \\
\text { and means of } \\
\text { promotion and } \\
\text { distribution of the } \\
\text { work. }\end{array}$ & $\begin{array}{l}\text { - Publisher's track record; } \\
\text { - Publisher's capability concerning the } \\
\text { effective promotion of the work. }\end{array}$ & 1 & $\begin{array}{lll} & 0 & \text { to } \\
5 & & \end{array}$ & 5 \\
\hline $\begin{array}{l}\text { d) Translator's } \\
\text { resumé. }\end{array}$ & $\begin{array}{l}\text { - Experience in direct translation of } \\
\text { Portuguese language literature. } \\
\text { - Admissibility of beginning } \\
\text { professionals as an incentive to the } \\
\text { qualification of new translators. }\end{array}$ & 1 & $\begin{array}{lll} & 0 \text { to } \\
5 & & \end{array}$ & 5 \\
\hline & & & Total & 25 \\
\hline
\end{tabular}

30.1. The minimum and maximum scores for each item will be 0 (zero) and 5 (five).

30.2 In case of applications with equal scores, the one with the highest score in item "a" will prevail. The scores remaining equal, the application with the highest scores in items "b", "c" or "d", consecutively, will prevail.

30.3 The scores remaining equal, the application claiming the lowest financial support from FBN will prevail.

30.4 The minimum score for qualification is 17,5 (seventeen point five). Any application that fails to achieve the minimum score will be disqualified.

30.5. Applications from CPLP publishers will be assessed in accordance with items "a" to "c". The minimum score for qualification will be 14

31. The committee will adopt the following criteria for establishing the amount of the grant, according to each application's particularities:

a) Estimated translation cost, given the average costs for the target languages.

b) Estimated publishing cost.

32. The Committee will submit to the Centre for Cooperation and Diffusion:

a) A list of selected applications;

b) A list of additional qualified applications.

32.1 Both lists will contain the following information 
I - Application's identification (title and author);

II - Country of origin;

III - Score awarded in the evaluation;

IV - Value of the grant; and

$\mathrm{V}$ - Name of the Committee members

33. The additional qualified applications may be awarded grants at a later date if funds are available at the discretion of FBN, in the descending order of qualification and within this Notice's validity.

34. The selection result will be announced by email directly to the awarded publisher until 7 (seven) business days after the evaluation meetings and will be made available on the FBN's website, as well as published in the official journal of Brazilian government.

35. Appeals to re-evaluate the list of selected proposals and granted values may be submitted via a specific form (Annex 4) within 4 (four) business days following the result's announcement by mail to translation@bn.gov.br.

35.1. The Centre for Cooperation and Diffusion will assess the appeals, in agreement with the members of the evaluation committee, within 5 (five) business days

\section{Section 9 - Granting procedure}

36. The awarded grant will be formalized by means of an agreement drafted in Portuguese* signed by the legal signatory of the publisher/institution and the president of the National Library.

* N.B. Brazilian Law requires all contracts to be written in Portuguese.

37. The agreement will be sent to the publisher for signature and return to the National Library.

38. The grants will be paid to the publisher in two installments as follows:

a) 1 st installment: $50 \%$ of the grant, following both parties' signature of an agreement. 
b) 2nd installment: $50 \%$ of the grant, following receipt by the National Library of 5 (five) copies of the work or the download of an a e-book copy.

38.1. The provision of updated banking and other relevant data is the sole responsibility of the publisher.

39. Within 5 (five) days after the announcement of the selection results, the publishers must provide the following additional documentation:

a) Publisher's bank details;

b) Publisher's legal representative identity document.

\section{Section 10 - Publisher's Obligations}

40. The publisher commits to provide 6 (six) copies of the work within up to 24 (twenty-four) months after an agreement are signed.

a) Five copies to the National Library;

b) One copy to the Brazilian Embassy or official representation in the publisher's country

40.1 In reference to grants for e-book editions, the publisher commits to provide a link to access and download the published work.

40.2 The deadline may be postponed for up to 12 (twelve) months provided that the publisher presents appeal and justification before the agreement expires.

40.2.1. Exceptionally, and in accordance with item 56 of this Notice, the incidence of supervening events, duly confirmed by the publisher, may lead to a review of established deadlines.

41. The publisher must print on the book's copyright page, both in the translation language and in Portuguese, the following credits:

“Obra publicada com o apoio do Ministério da Cultura do Brasil | Fundação Biblioteca Nacional."

41.1. The credits must be placed along with the National Library logo, in accordance with the following specifications: 


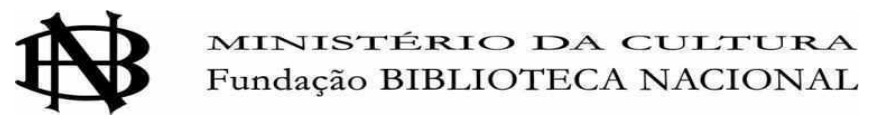

Minimum measurements for placement of the logo on the acknowledgements page:
a) Height: $0.71 \mathrm{~cm}$
b) Width: $4.00 \mathrm{~cm}$
c) Resolution: 300 dpi
Color specifications:
a) Black 100\% (K100\%); or
b) Pantone $456 \mathrm{C}$; or
c) Pantone $201 \mathrm{C}$.

41.2. Logo and credits may be placed elsewhere on the book with prior approval by the National Library.

42. Prior to printing the work, the publisher must present a proof of the copyrights page for approval.

42.1 Exceptionally, and with the National Library's approval, the publisher will be allowed to insert the logo and acknowledgement after the book is published. 43. With regard to print editions only, the publisher commits to publish at least 1,000 (one thousand) copies of the work, and 500 (five hundred) copies in case of reissues.

43.1. Print editions with less than 1,000 (one thousand) copies will necessarily be the object of special scrutiny by the Evaluation Committee 44. The publisher holds itself responsible for correctly submitting the documentation pertaining to the agreement and the authorizations arising from copyright and related rights, without which the agreement cannot be formalized.

44.1 The publisher must:

a) Immediately inform the National Library of any serious issue that may lead to a discontinuation of the project, which may lead to modifying or interrupting the execution of the Agreement. 
b) Immediately inform the National Library of any change in the publisher's legal representative or of the publisher's employee responsible for the work to be translated;

c) Reimburse the National Library for any funds wrongly received.

d) Provide the National Library with a receipt signed by the translator confirming the honorarium was payed.

e) Provide the National Library with a printing receipt of the number of copies established in accordance with the application form.

45. Non-compliance with the terms and conditions of the Agreement will lead to the application of penalties by the National Library.

\section{Section 11 - Penalties}

46. Should the publisher not deliver the work according to the terms and conditions provided in this Notice, and as defined in the Agreement, the publisher will be required to return the amount of the first installment with monetary correction and interests.

47. Non-compliance with the terms and conditions provided in this Notice and as defined in the Agreement may entail the following penalties and restrictions on future applications by the publisher:

a) Failure to comply with deadline for delivery of the work once the possibilities of readjustment of the publication schedule have been exhausted: refunding of the first installment with monetary correction and interests, according to legal requirements, and refusal of new applications for up to 3 (three) years, depending on the assessment of the Centre for Cooperation and Diffusion.

b) Cancellation of the project after payment the first installment: refunding of the first installment with monetary correction and interests, according to legal requirements, and refusal of new applications for up to 3 (three) years, depending on the assessment of the Centre for Cooperation and Diffusion.

c) Non-payment of the translator's honorarium: refusal of any future applications to the National Library's funding programs. 
d) Non-compliance with the Portuguese Language Orthographic Agreement of 1990, in accordance with Item 11 of this Notice: grant's cancellation and refunding of the first installment with monetary correction and interests, according to legal requirements.

\section{Section 12 - Follow-up and Evaluation}

48. The publisher commits to provide information, over the course of the agreement period, on the translation schedule; production stages and estimated release date as requested by the National Library.

49. Six months following the publication, even if exceeds the agreement period, the publisher may be asked to submit a status report on the distribution and marketing plan.

\section{Section 13 - Final Provisions}

50. This Notice will be available on the websites of the National Library (www.bn.gov.br) and of the Ministry of Culture (www.cultura.gov.br) and will be published in the official journal of Brazilian government (Diário Oficial da União)

51. For any queries related to this Notice, the interested party should contact by phone (+55 21 2220-2796) or by e-mail (translation@bn.gov.br).

52. The documents submitted along with the application will not be returned to the applicant, and the National Library will decide whether to archive or to dispose of the documents at a later date.

53. The National Library reserves the right to publish passages of the funded works in publications with the purpose of promoting Brazilian literature the Support Program for the Translation and Publication of Brazilian Authors Abroad, with the permission of the authors and the translators.

54. The costs incurred to participate in this selection process, including copies, postage, document issuing and the like, are the sole responsibility of the applicant. 
55. By submitting the application, the applicant expressly acknowledges that he/she fully and irrevocably consents to and agrees with all of the items contained in this announcement

56. The National Library's direction will resolve any overlooked matters.

57. Any irregularities pertaining to participation requirements, reavealed at any time, will entail disqualification of the application.

58. All submitted applications, whether or not selected, will be registered by the National Library for the purposes of monitoring, documentation and mapping of the Brazilian cultural production.

Helena Severo

President

Fundação Biblioteca Nacional 


\section{Dados da editora}

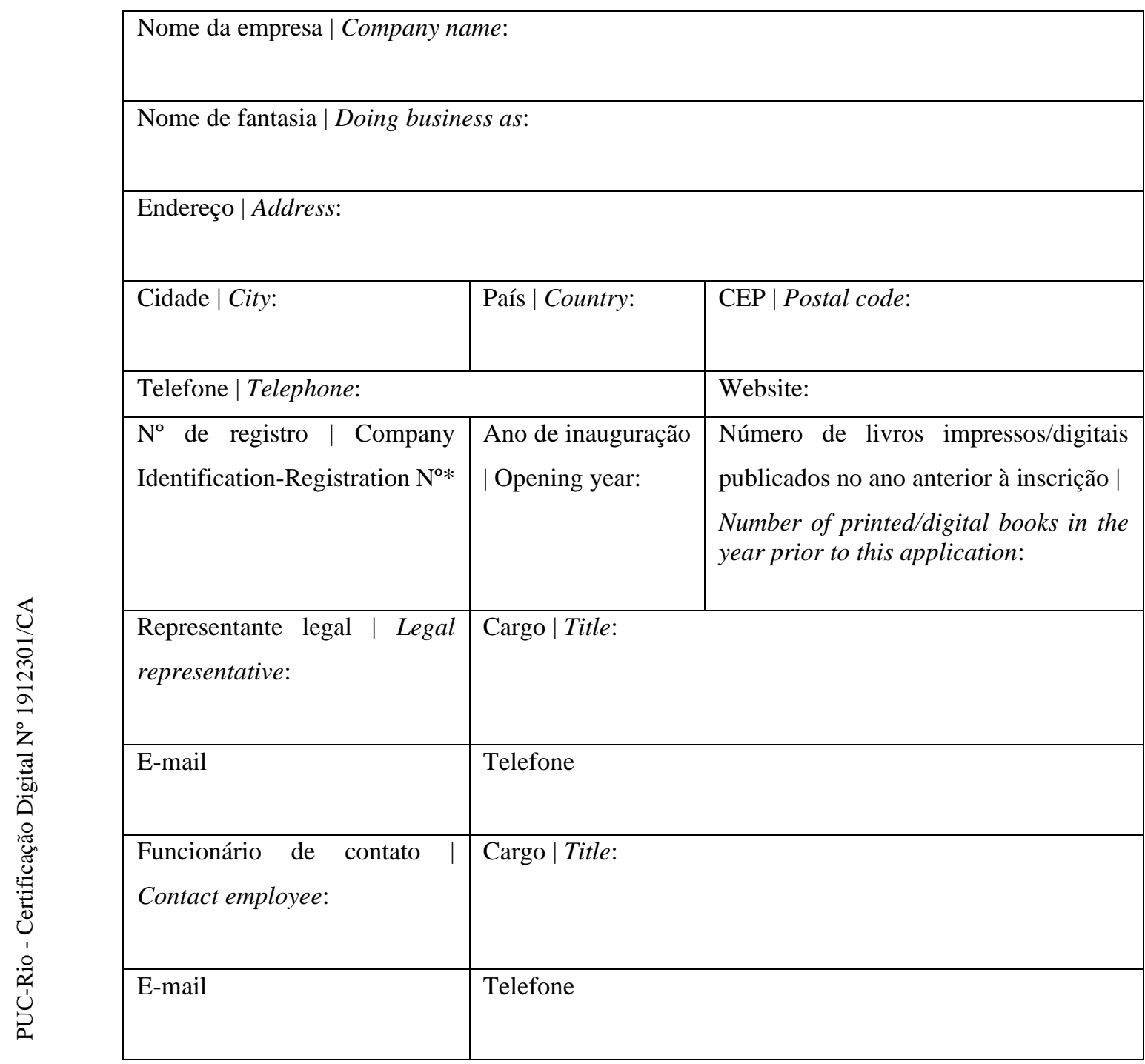

*CUIT, P.IVA, SUNAT, Federal Tax Identification Number entre outros.

Breve histórico da editora | Brief account of the publisher's track record

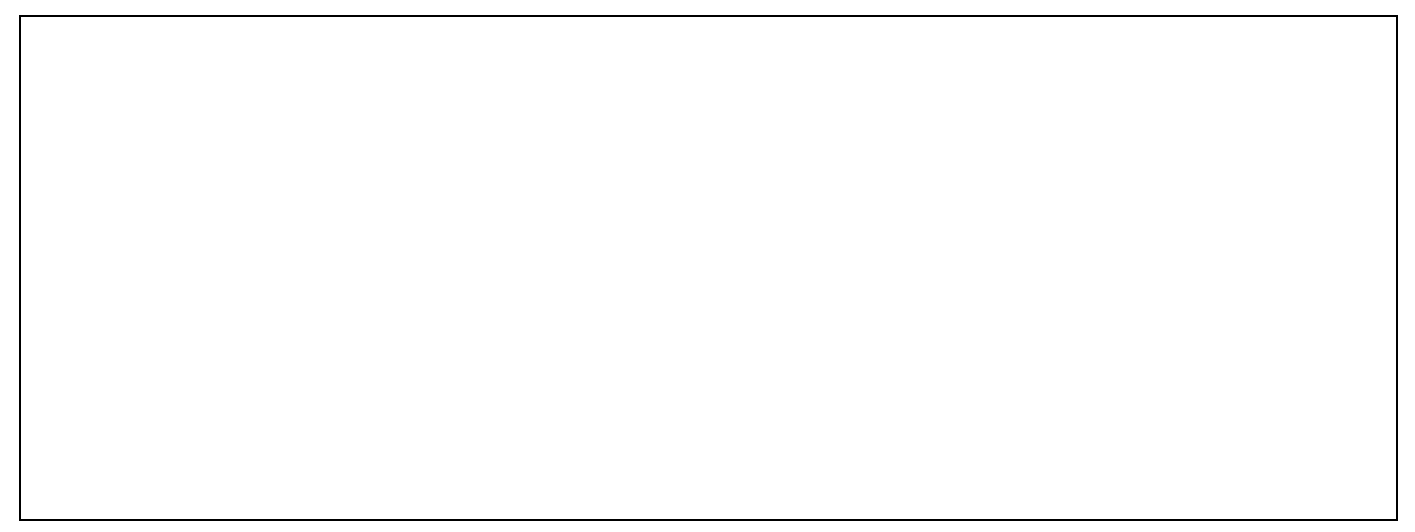


Dados da obra | Work information

\begin{tabular}{|c|c|c|}
\hline \multicolumn{3}{|l|}{ Título | Title } \\
\hline \multicolumn{2}{|l|}{ Autor | Author } & $\begin{array}{l}\text { Editora brasileira adotada (editora / ano de publicação) } \\
\text { Brazilian edition (publisher/year) }\end{array}$ \\
\hline \multicolumn{3}{|c|}{$\mathrm{N}^{\circ}$ de páginas em português $\mid$ No. of pages in Portuguese } \\
\hline Gênero literário | Genre & \multicolumn{2}{|l|}{ ISBN } \\
\hline \multicolumn{3}{|c|}{ Apresentação | Description } \\
\hline \multicolumn{3}{|c|}{ Dados do tradutor (se aplicável) | Translator information } \\
\hline \multicolumn{3}{|l|}{ Nome | Name } \\
\hline \multicolumn{3}{|l|}{ Endereço | Address } \\
\hline Cidade | City & País $\mid$ Country & CEP $\mid$ Postal code \\
\hline Telefone | Telephone & E-mail & $\begin{array}{l}\text { Língua de tradução | Target } \\
\text { language }\end{array}$ \\
\hline
\end{tabular}




\section{Dados da publicação (dados editoriais sobre o projeto de tradução e publicação) | Publication information (on the translation/publication Project)}

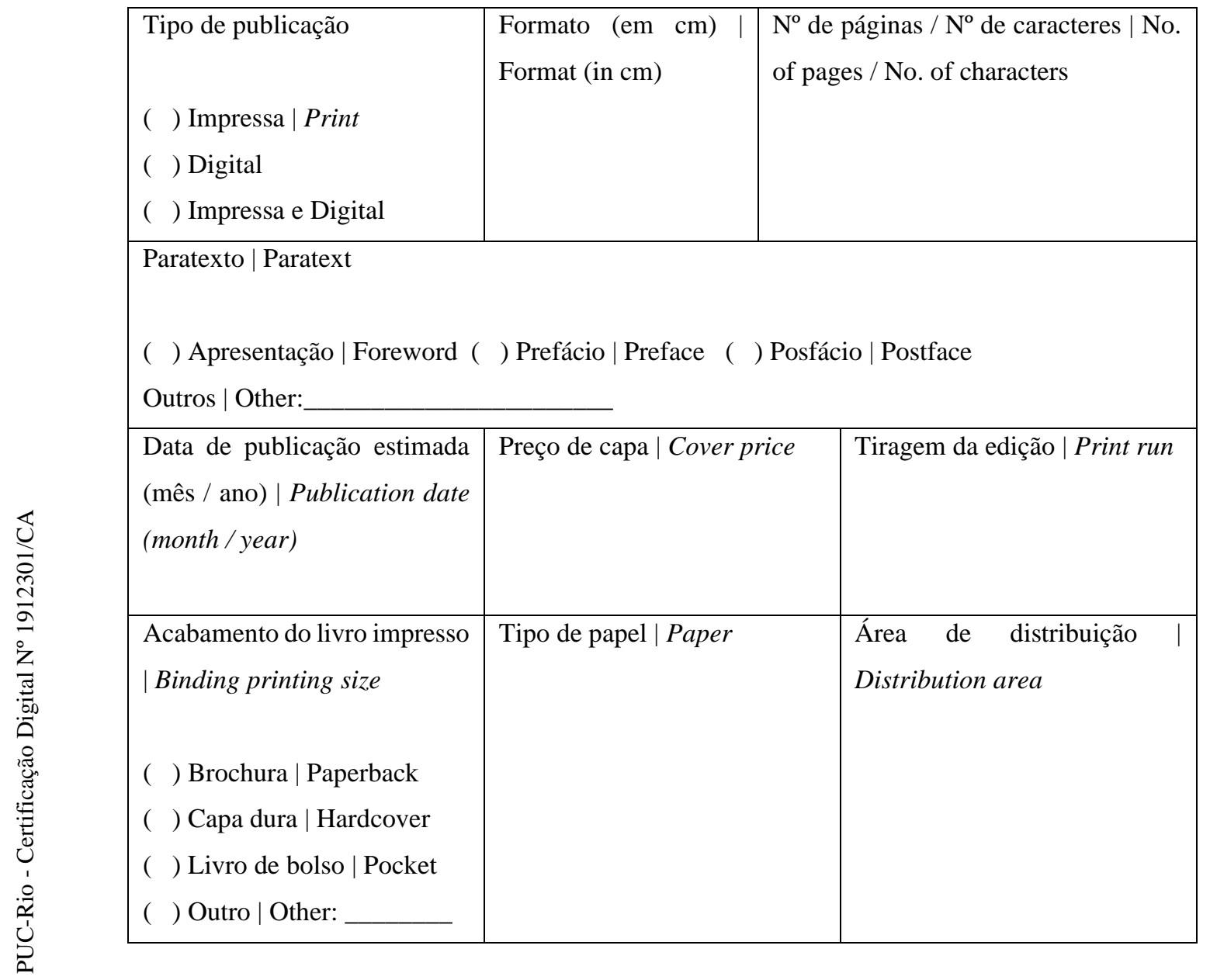




\section{Orçamento}

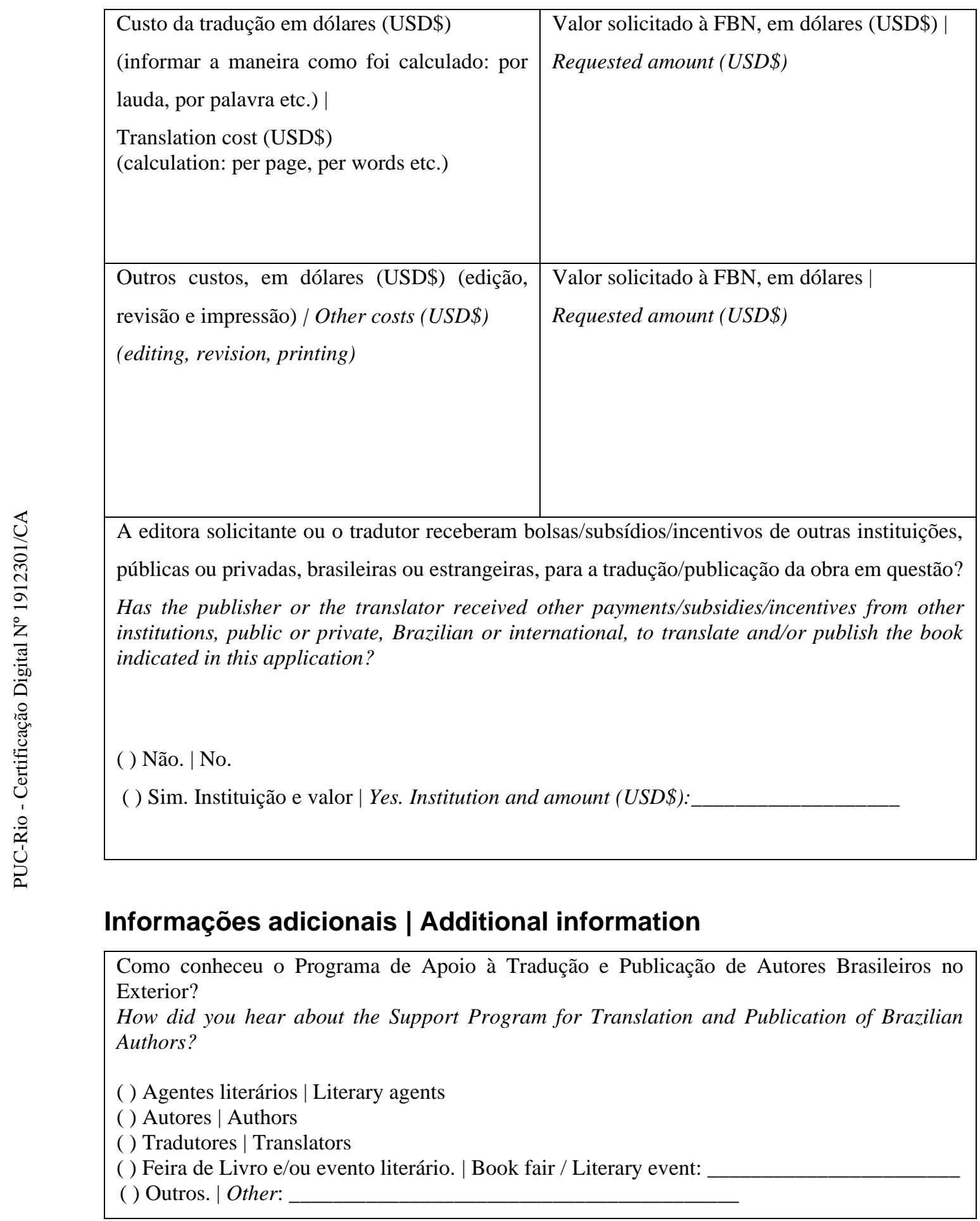




\section{Declaração | Statement (Please, fill in the form written in Portuguese)}

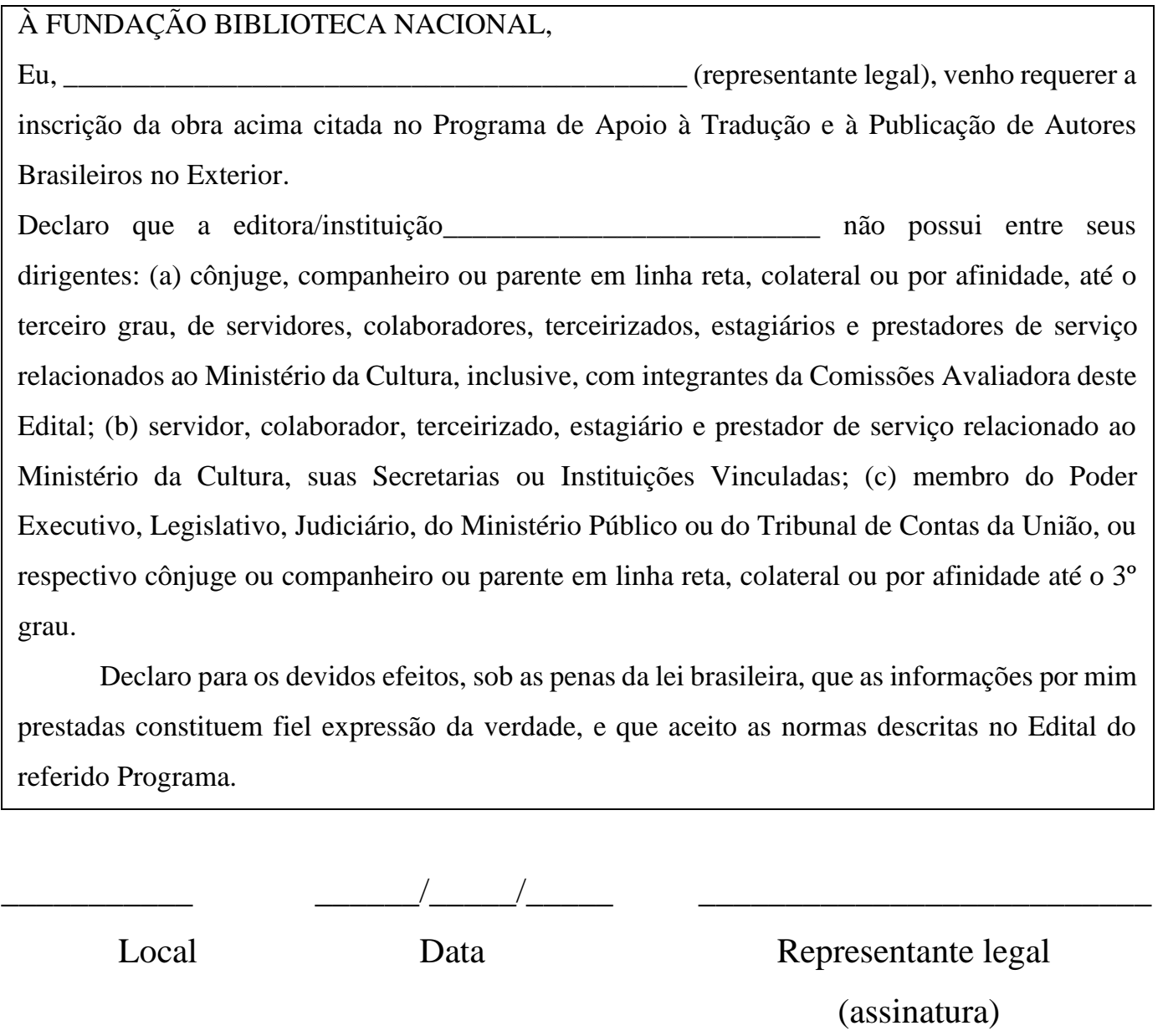

*Statement to Fundação Biblioteca Nacional

I, the undersigned, (PUBLISHER'S LEGAL REPRESENTATIVE), declare that I wish to apply for the aforementioned work to be considered for a grant within the Support Program for the Translation and Publication of Brazilian Authors Abroad..

I declare that the publisher/institution (PUBLISHER'S NAME) does not have as directors: a) spouse, partner or relative in a direct line, collateral or by affinity up to the third degree, of public servants, associates, outsourced employees, trainees and service providers related to the Ministry of Culture, including members of the Evaluation Committee of this Program; b) public servant, associate, outsourced employee, trainee and service provider related to the Ministry of Culture, its Secretariats or Related Institutions; c) member of the Executive, Legislative, Judiciary, Prosecution Service of the Union or of the Federal Court of Accounts, or their spouse or partner or relative in a straight line, collateral or by affinity up to the third degree. 
I also declare, for the purposes of this application and under the Law of Brazil, that the details provided by me in this application are true and that I accept the terms contained in the official Announcement of the aforementioned grant program. 


\section{Anexo 2 - Comprovação da Cessão dos Direitos Autorais Patrimoniais de Obra}

Declaro, na qualidade de representante legal da Editora situada em , ser ela titular dos direitos autorais patrimoniais, para fins de tradução e posterior publicação em língua da obra original publicada em português no Brasil, com o título:

de

Autoria

de , de acordo com o instrumento legal

efetivado com Autor e/ou seu representante legal, cuja cópia segue em anexo.

Declaro, ainda, que a mesma possui contrato de tradução, cuja cópia segue em anexo, devidamente legalizado com o $\operatorname{Sr}(\mathrm{a})$ : , que executará o serviço de tradução, de cujos direitos autorais patrimoniais é titular.

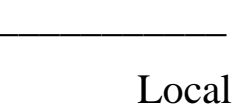

Local

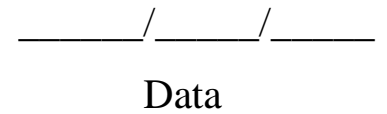

Representante legal

(assinatura)

\footnotetext{
* I declare, as legal representative of (PUBLISHER) located in (CITY / COUNTRY), that this Publisher holds all copyrights and other related rights, for purposes of translation and publication in the (TARGET LANGUAGE) of the original work published in Portuguese in Brazil, with the title: (PORTUGUESE TITLE), authored by (AUTHOR'S NAME), in accordance with the legal instrument signed by the Author and/or legal representative of the Author, a copy of which is attached.

We further declare that the Publisher holds the translation contract, a copy of which is attached, duly legalized by Mr./Ms.(TRANSLATOR'S NAME), who will perform the translation and that the Publisher holds the copyrights for this work.
} 


\section{Anexo 3 - Comprovação da Cessão dos Direitos Autorais Patrimoniais de Obra}

(Para Editoras de Países de Língua Portuguesa)

Declaro, na qualidade de representante legal da Editora

situada em , ser ela titular dos direitos autorais patrimoniais, para fins de publicação em , país membro da

Comunidade dos Países de Língua Portuguesa da obra original publicada em português no Brasil, com

O título: , de Autoria de , de acordo com o instrumento legal efetivado com Autor e/ou seu representante legal, cuja cópia segue em anexo. Declaro, ainda, que a mesma possui contrato de cessão de direitos autorais, cuja cópia segue em anexo, devidamente legalizado com o $\operatorname{Sr}(\mathrm{a})$ : Local

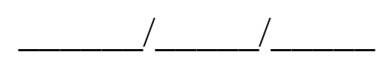

Data

Representante legal (assinatura) 


\section{Anexo 4 - Formulário de Recurso \\ Annex 4 - Appeal Request Form}

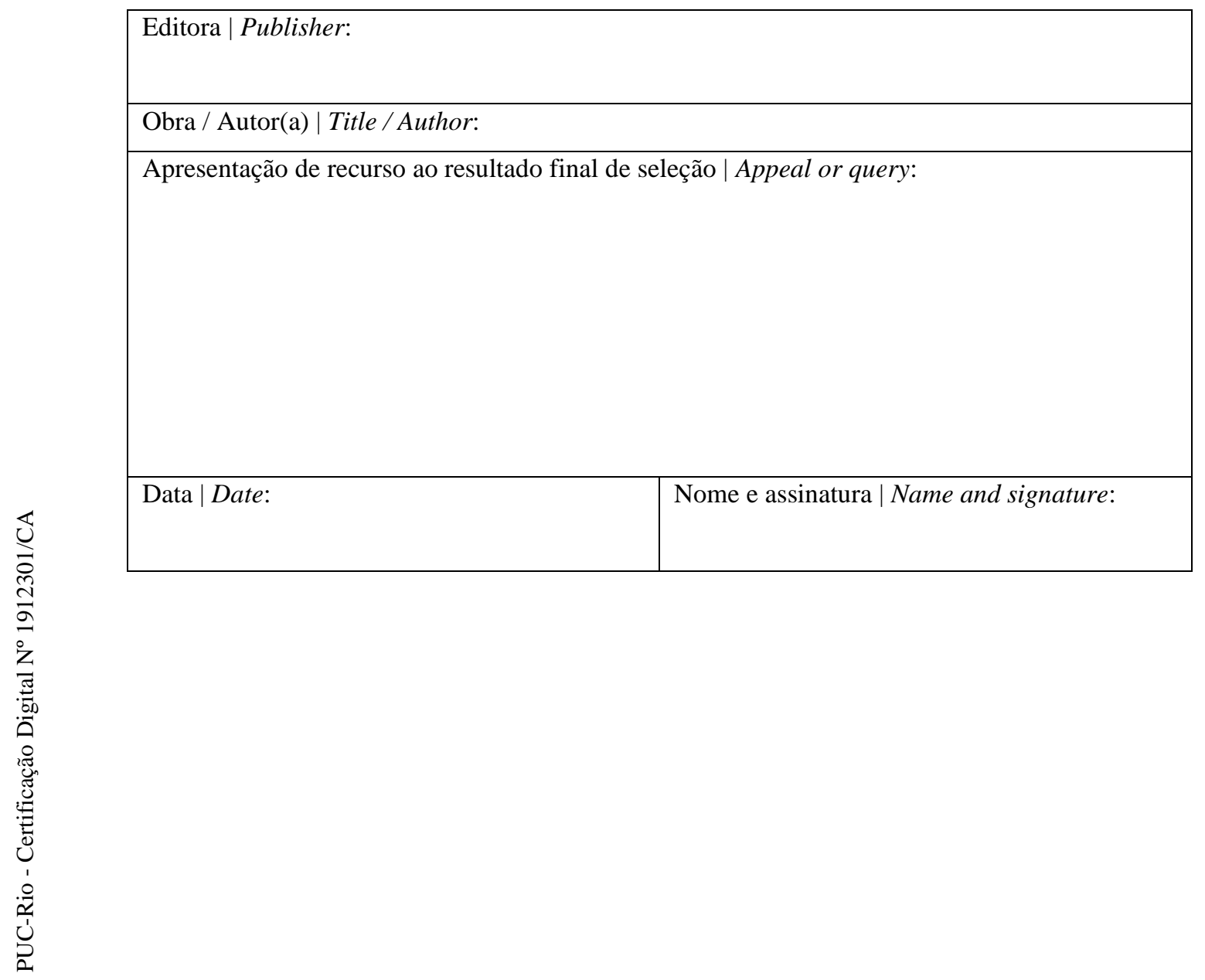




\section{Anexo C \\ Edital do Programa de Residência de Tradutores Estrangeiros no Brasil no 1 / 2016}

A Fundação Biblioteca Nacional torna público que oferecerá bolsas a tradutores estrangeiros tendo em vista períodos de residência no Brasil. Este procedimento, autorizado por meio de Decisão Executiva n ${ }^{\circ} 24$ - FBN, de 18 /07/ 2016, será regido pelo Edital que se segue, bem como, no que couber, pela Portaria MinC no 29/2009.

\section{Seção I - Objeto}

1. O Programa de Residência de Tradutores Estrangeiros no Brasil, criado pela Fundação Biblioteca Nacional (FBN), instituição vinculada ao Ministério da Cultura, objetiva difundir a cultura e a literatura brasileiras no exterior, por meio da concessão de bolsas a tradutores estrangeiros com a finalidade de apoiar o custeio de períodos de residência no Brasil.

2. O Programa é destinado a tradutores do português para qualquer idioma com projetos contratados, já iniciados, de tradução de obras de autores brasileiros publicadas previamente no Brasil.

2.1 Para efeitos deste Edital serão considerados autores brasileiros aqueles nascidos no Brasil ou naturalizados. Autores que não se enquadrem nessas condições serão analisados mediante avaliação especial da Comissão Avaliadora do Programa.

3. O Programa poderá apoiar tradutores com projetos no âmbito da literatura e de humanidades, especialmente os seguintes gêneros: romance, conto, poesia, crônica, infantil e/ou juvenil, teatro, obra de referência, ensaio literário, ensaio de ciências sociais, ensaio histórico, ensaio de vulgarização científica e antologias de poemas e contos, integrais ou em parte.

4. As bolsas concedidas pelo Programa deverão cobrir, parcial ou totalmente, as despesas necessárias para permanência do tradutor no Brasil durante um período de 15 a 30 dias, entre 17 de outubro e 20 de dezembro de 2016. 
4.1. Parte do período de residência deverá ser preenchida por uma programação específica para cada tradutor a ser elaborada pela FBN em parceria com centros de estudos de tradução, universidades e instituições culturais. A programação poderá incluir a participação em debates com autores, tradutores e outros interlocutores, participação em oficinas de tradução e visitas a instituições culturais. A presença é obrigatória.

\section{Seção II - Condições para participação}

5. Podem participar deste Edital tradutores estrangeiros que trabalhem com a língua portuguesa com projetos de tradução já iniciados e contratados por editoras estrangeiras.

6. A tradução não deve estar concluída antes da vinda do tradutor ao Brasil.

7. Apenas serão aceitos projetos de tradução realizada diretamente do português para outros idiomas.

8. A tiragem mínima prevista da obra em referência deverá ser de 500 exemplares.

\section{Seção III - Vigência}

9. Este Edital terá vigência de 12 (doze) meses, a contar da data de publicação no Diário Oficial da União, podendo ser prorrogada, em caso de necessidade, por um período de até 12 (doze) meses.

\section{Seção IV - Recursos orçamentários}

10. Para atender aos objetivos deste Edital, estão previstos recursos no valor de $\mathrm{R} \$$ 30.000 (trinta mil reais), provenientes da Lei Orçamentária Anual - LOA e/ou do Fundo Nacional de Cultura - FNC, conforme disponibilidade orçamentária. 


\section{Seção V - Benefícios}

11. Serão concedidas 3 (três) bolsas de até $\mathrm{R} \$ 10.000,00$ (dez mil reais) a tradutores para qualquer idioma estrangeiro.

12. O valor da bolsa levará em consideração:

a. o número de dias de permanência no Brasil, sendo o mínimo de 15 e o máximo de 30 dias, tendo por base o valor das diárias da categoria "E", pago a servidores públicos federais em deslocamentos no País, conforme Decretos $\mathrm{N}^{\mathrm{o}} 5.992$, de 19/12/2006 e No 6.907, de 21/07/2009;

b. o custo estimado de passagens aéreas e terrestres, nacionais e internacionais. 13. A concessão das bolsas está condicionada à existência de disponibilidade orçamentária e financeira, caracterizando a seleção como expectativa de direito do proponente.

\section{Seção VI - Apresentação e envio das inscrições}

14. As inscrições para o Programa estarão abertas a partir da data de publicação deste edital até 02 de setembro de 2016. As etapas de recebimento, habilitação e avaliação das inscrições seguirão o cronograma abaixo*:

\begin{tabular}{|l|l|l|l|l|l|l|}
\hline $\begin{array}{l}\text { Prazo para } \\
\text { recebimento } \\
\text { de }\end{array}$ & $\begin{array}{l}\text { Divulgação } \\
\text { da lista de } \\
\text { inscrições }\end{array}$ & $\begin{array}{l}\text { Prazo para } \\
\text { inscrições } \\
\text { habilitadas }\end{array}$ & $\begin{array}{l}\text { Divulgação } \\
\text { recursos }\end{array}$ & $\begin{array}{l}\text { Reunião de } \\
\text { da rista } \\
\text { final de } \\
\text { inscrições } \\
\text { habilitadas }\end{array}$ & $\begin{array}{l}\text { Divulgação } \\
\text { avaliação } \\
\text { da lista de } \\
\text { projetos } \\
\text { aprovados }\end{array}$ & $\begin{array}{l}\text { Período de } \\
\text { residência }\end{array}$ \\
\hline $02 / 09 / 2016$ & $08 / 09 / 2016$ & $12 / 09 / 2016$ & $13 / 09 / 2016$ & $19 / 09 / 2016$ & $26 / 09 / 2016$ & $\begin{array}{l}17 / 10 / 2016 \\
\text { a } \\
20 / 12 / 2016\end{array}$ \\
\hline
\end{tabular}

* Datas prováveis

15. As inscrições serão gratuitas.

16. Para inscrever-se, o tradutor deverá enviar à FBN, no momento da inscrição, os seguintes documentos via e-mail (para tradutoresbrasil@bn.gov.br) por via postal: 
a. Carta de apresentação e plano de trabalho para o período de residência, que deverá incluir possíveis itinerários, deslocamentos dentro do Brasil e cronograma de atividades propostas com a especificação do número de dias de permanência (cf. item 12). O tradutor poderá apresentar um itinerário que o leve a cidades em diferentes regiões do país, de acordo com o universo da obra e do autor traduzido e com a necessidade de visitar instituições e interlocutores relevantes para o seu trabalho. O plano deverá incluir uma estimativa dos custos de transporte aéreo e terrestre;

b. Formulários de inscrição (Anexos I,II e III) totalmente preenchidos (digitados). O anexo II deverá ser preenchido pelo representante legal da editora estrangeira;

c. Amostra da tradução acompanhada do texto em português (no mínimo $10 \%$ da obra);

d. Currículo do tradutor em português;

e. Documento de identificação pessoal;

f. Carta de apresentação e catálogo da editora estrangeira;

g. Cópia do contrato estabelecido entre o tradutor e a editora estrangeira;

h. Cópia do contrato de cessão de direitos autorais da obra, estabelecido entre a editora e o(s) autor(es) ou seus representantes legais, sempre que a obra não estiver em domínio público;

16.1 O formulário de inscrição original devidamente assinado (alínea b) deverá obrigatoriamente ser encaminhado por via postal à FBN, no endereço:

Fundação Biblioteca Nacional

Centro de Cooperação e Difusão

Programa de Residência de Tradutores Estrangeiros no Brasil

Rua da Imprensa, 16/1102 - Centro

20030-120 - Rio de Janeiro - RJ - Brasil

16.2 Inscrições por via postal devem ser encaminhadas para o endereço acima indicado. 
16.3 Não serão aceitas inscrições por via postal recebidas após o prazo indicado no cronograma, independentemente da data de envio.

17. O proponente será o único responsável pela veracidade da proposta e dos documentos encaminhados, isentando a Fundação Biblioteca Nacional e o Ministério da Cultura de qualquer responsabilidade civil ou penal por eventuais erros ou equívocos.

\section{Seção VII - Etapa de habilitação}

18. Para a habilitação da inscrição será necessário o envio dos documentos e dos formulários, devidamente preenchidos, em conformidade com o item 16 deste Edital. 19. Será desconsiderada a inscrição apresentada com ausência de informações que possa prejudicar a análise.

20. Apenas as inscrições habilitadas serão submetidas à fase de avaliação e seleção, sendo inabilitados os projetos que não cumprirem os requisitos dispostos no item 16 deste Edital.

21. Após o término do prazo de recebimento de inscrições será divulgada em até 2 (dois) dias úteis, no sítio eletrônico da Fundação Biblioteca Nacional (www.bn.br), a lista de projetos habilitados que conterá o nome do autor e do proponente e a razão do indeferimento se for o caso.

22. A divulgação da lista preliminar de inscrições habilitadas dar-se-á por meio de publicação no sítio eletrônico da Fundação Biblioteca Nacional (www.bn.br).

23. Caberá pedido de reconsideração da inabilitação, a ser enviado no prazo de 2 (dois) dias corridos, por meio de e-mail, a contar do dia subsequente da data de divulgação do resultado para o seguinte endereço: tradutoresbrasil@bn.br.

24. Compete ao Centro de Cooperação e Difusão/FBN (CCD/FBN) proceder ao exame de habilitação das inscrições e eventuais pedidos de reconsideração. 25. O resultado final da fase de habilitação será divulgado por meio de publicação no sítio eletrônico da Fundação Biblioteca Nacional (www.bn.br). 


\section{Seção VIII - Avaliação e Seleção}

26. A Comissão Avaliadora será nomeada por meio de Decisão Executiva pelo Presidente da FBN. Esta comissão será responsável por avaliar as propostas recebidas e indicar as inscrições aprovadas, observando-se a imparcialidade, transparência e impessoalidade no julgamento das propostas.

26.1 A comissão será composta por tradutores, professores e/ou pesquisadores brasileiros da área de literatura e tradução.

26.2 A comissão será presidida por representante do Centro de Cooperação e Difusão da Fundação Biblioteca Nacional.

27. A comissão adotará como critérios de seleção:

a. Relevância da obra em referência para a promoção e divulgação da cultura e da literatura brasileira no exterior;

b. Consistência do plano de trabalho e necessidade da pesquisa in loco inerente ao projeto;

c. Índice de dificuldade linguística da tradução;

d. Currículo do tradutor.

27.1 As notas mínima e máxima para o critério previsto na alínea "a" serão, respectivamente, 0 e 10 .

27.2 As notas mínima e máxima para o critério previsto na alínea "b" serão, respectivamente, 0 e 10 .

27.3 As notas mínima e máxima para o critério previsto na alínea "c" serão, respectivamente, 0 e 10 .

27.4 As notas mínima e máxima para o critério previsto na alínea "d" serão, respectivamente, 0 e 10 .

27.6 A pontuação mínima de classificação será 28 (70\% da pontuação máxima), sendo desclassificados os projetos que não a atingirem.

27.5 Em caso de empate, prevalecerá o projeto que receber maior nota no critério a, e em seguida nos critérios b, c e d. Persistindo o empate, o critério será o sorteio. 
27.6 Em caso de empate, projetos cujos tradutores não tenham sido contemplados em anos anteriores prevalecerão sobre projetos cujos tradutores já tenham sido contemplados.

27.7 Caberá à comissão de seleção encaminhar à unidade gestora da seleção pública a lista de selecionados e a lista de classificados, que serão chamados no caso de eventuais desistências ou impedimentos dos projetos selecionados.

27.8 A lista de selecionados e a lista de classificados deverão conter:

I - nome do tradutor;

II - idioma da tradução;

III - nota obtida na avaliação;

IV - valor do apoio;

$\mathrm{V}$ - nome dos membros da comissão de seleção.

27.9 Os projetos classificados poderão ser contemplados posteriormente em caso de disponibilidade de recursos, a critério da unidade gestora da seleção pública e respeitada a prioridade aos selecionados, a ordem decrescente de pontuação e o prazo de vigência da seleção pública.

28. Os resultados finais da seleção serão comunicados diretamente aos tradutores selecionados, por escrito ou por correio eletrônico na data provável de 26 de setembro de 2016 e ficarão disponíveis no portal FBN, bem como serão publicados no Diário Oficial da União.

29. Caberá pedido de reconsideração da lista de projetos selecionados, a ser enviado no prazo de 2 (dois) dias úteis, por meio de correio eletrônico, a contar do dia subsequente da data de divulgação do resultado, para o seguinte endereço tradutoresbrasil@bn.br.

29.1 Os pedidos de reconsideração serão analisados pelo Centro de Cooperação e Difusão em concordância com os demais membros da Comissão Avaliadora.

\section{Seção IX - Concessão}

30. A formalização da concessão da bolsa será objeto de Termo de Compromisso redigido em língua portuguesa, firmado pelo tradutor e pelo Presidente da FBN. 
31. O respectivo Termo de Compromisso será enviado ao tradutor para assinatura e devolução à FBN.

32. No momento da assinatura do Termo de Compromisso, o tradutor deverá encaminhar cópias dos seguintes documentos:

a. comprovante de residência;

b. passaporte;

c. visto para estrangeiro, quando exigido;

d. comprovante de vacinação, conforme exigências da autoridade sanitária do Brasil.

33. As bolsas serão pagas pela FBN ao tradutor em duas parcelas, da seguinte forma.

a. $1^{\text {a }}$ parcela: $50 \%$ da bolsa após assinatura do Termo de Compromisso pelas duas partes;

b. $2^{\mathrm{a}}$ parcela: $50 \%$ da bolsa na chegada do tradutor ao Brasil.

\section{Seção X - Obrigações do tradutor}

34. O tradutor deverá permanecer no Brasil durante um período mínimo de 15 dias, entre 17 de outubro e 20 de dezembro de 2016, e executar as atividades propostas no plano de trabalho.

34.1 Após a concessão da bolsa, caso algum fator venha impedir ou prejudicar a vinda do tradutor a Brasil conforme os termos inicialmente previstos, as datas do período de residência poderão ser reajustadas mediante avaliação da FBN.

35. Após a chegada ao Brasil, o tradutor deverá apresentar à FBN o comprovante da compra de um seguro viagem.

36. O tradutor dedicará parte do período de residência às atividades propostas pela FBN em parceria com centros de estudos de tradução, universidades e instituições culturais. 37. Em até 15 (quinze) dias após o tempo estipulado de residência, o tradutor deverá apresentar um relatório detalhado com as seguintes informações:

a. Descrição das atividades desenvolvidas. 
b. Comprovantes (bilhete, cartão de embarque ou nota fiscal) das passagens aéreas e terrestres, nacionais e internacionais.

38. O tradutor se responsabiliza pela correta apresentação da documentação relativa ao Termo de Compromisso e às autorizações decorrentes aos direitos de autor e conexos presentes na obra, sem a qual o mesmo não poderá ser formalizado.

39. A obra traduzida, quando publicada, deverá incluir a seguinte referência na página de créditos, na língua da tradução e em português: "O tradutor desta obra recebeu uma bolsa do Programa de Residência de Tradutores Estrangeiros no Brasil, do Ministério da Cultura do Brasil / Fundação Biblioteca Nacional".

39.1. A referência acima especificada deverá ser acompanhada dos logotipos da Fundação Biblioteca Nacional, conforme imagens abaixo e suas especificações:

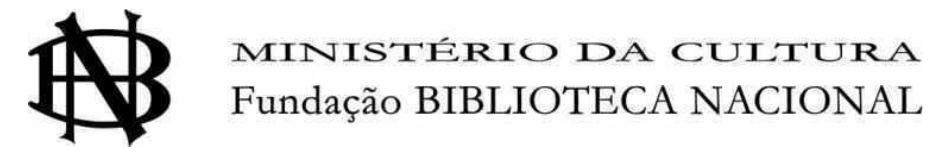

Medidas mínimas para aplicação do logotipo na página de créditos:
a. Altura: $0,71 \mathrm{~cm}$
b. Largura: $4,00 \mathrm{~cm}$
c. Definição: 300 dpi

Especificação das cores:

a. Preto/Black 100\% (K100\%); ou

b. Pantone $456 \mathrm{C}$; ou

c. Pantone $201 \mathrm{C}$.

39.2. O logotipo e a referência ao apoio concedido poderão ser inseridos em local diferente da página de créditos mediante aprovação prévia por parte da FBN.

39.3 Antes da publicação da obra, a editora deverá enviar à FBN prova da página de créditos, para aprovação. 
40. A editora da obra traduzida deverá encaminhar à FBN cinco exemplares demonstrativos da publicação.

\section{Seção XI - Penalidades}

41. O descumprimento de cláusulas deste Edital ou do Termo de Compromisso firmado entre a Editora e a FBN poderá implicar penalidades e restrições a futuras inscrições de acordo com os seguintes critérios:

a. Encerramento do período de residência antes do tempo estipulado no momento da concessão da bolsa: 1 (um) ano sem apresentar novas inscrições, além da devolução do valor correspondente aos dias não cumpridos;

b. Não-apresentação dos itens obrigatórios à prestação de contas (item 37 do Edital): 3 (três) anos sem apresentar novas inscrições, além da devolução do valor concedido.

c. Demora ou desatenção no atendimento de decisão da FBN em cancelar o apoio concedido e/ou devolução do valor concedido: 5 (cinco) anos sem apresentar novas inscrições e medidas judiciais cabíveis.

\section{Seção XII - Disposições Finais}

42. Este Edital estará disponível no endereço eletrônico da Fundação Biblioteca Nacional (www.bn.br) e do Ministério da Cultura do Brasil (www.cultura.gov.br) e será publicado no Diário Oficial da União.

43. Para esclarecimento de dúvidas, entrar em contato através do telefone +5521 2220-2057 ou pelo e-mail tradutoresbrasil@bn.gov.br.

44. Os materiais encaminhados pelos tradutores não serão devolvidos, cabendo à Fundação Biblioteca Nacional a decisão sobre seu arquivamento ou destruição. 45. As candidaturas inscritas, selecionadas ou não, passarão a fazer parte do cadastro da Fundação Biblioteca Nacional para fins de pesquisa, documentação e mapeamento da produção cultural brasileira. 
46. A Fundação Biblioteca Nacional se reserva o direito de publicar trechos das obras traduzidas com apoio deste Edital em publicações para fins de promoção da literatura brasileira e divulgação de seus programas e editais, em concordância com os autores e tradutores.

47. O ônus da participação no processo seletivo, incluídas as despesas com cópias, correio e emissão de documentos é de exclusiva responsabilidade do proponente. 48. O ato de inscrição pressupõe que o tradutor manifesta plena e irretratável anuência com relação a todos os itens do presente Edital.

49. Os casos omissos serão resolvidos pela direção da Fundação Biblioteca Nacional.

\section{Luiz Fernando Zugliani \\ Presidente em Exercício}




\section{Programa de Residência de Tradutores Estrangeiros no Brasil Anexo I - Formulário de inscrição}

\section{Dados do(a) tradutor(a)}

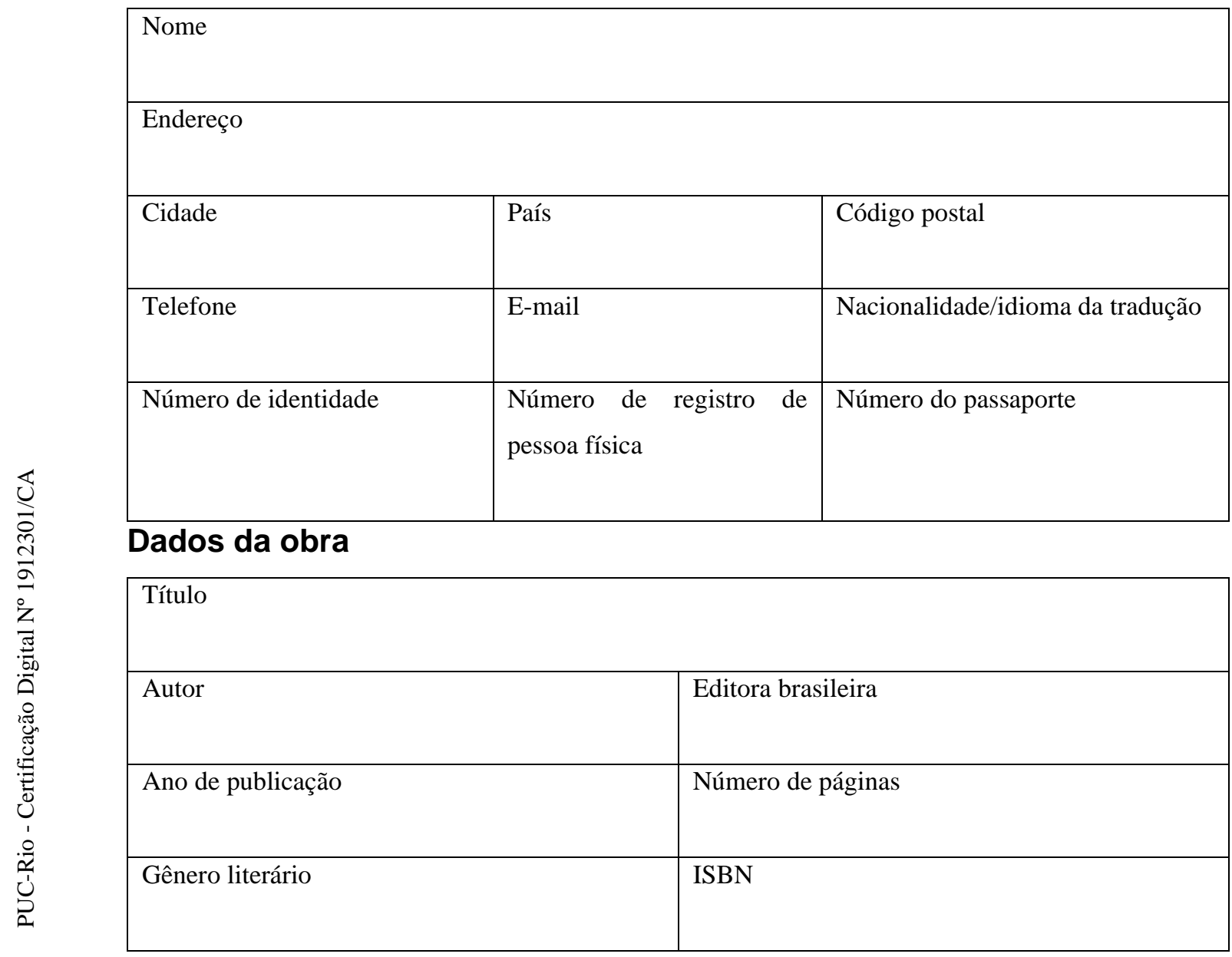

Dados bancários do(a) tradutor(a)

\begin{tabular}{|l|l|l|}
\hline \multicolumn{2}{|l|}{ Nome do proponente/beneficiário } \\
\hline Banco \\
\hline \multicolumn{2}{|l|}{} \\
\hline Endereço da agência & País & Código postal \\
\hline Cidade & Agência & Conta corrente \\
\hline Número do banco & SWIFT/BIC & \\
\hline IBAN & \multicolumn{2}{l}{} \\
\hline CLABE, CBU (se aplicável) & \multicolumn{2}{|l}{} \\
\hline
\end{tabular}




\section{Dados da editora}

\begin{tabular}{|l|l|l|}
\hline \multicolumn{2}{|l|}{ Nome da empresa } \\
\hline Nome de fantasia & País & Código postal \\
\hline Cidade & Fax & Website \\
\hline Telefone & Ano de inauguração & $\begin{array}{l}\text { Número de livros impressos/digitais } \\
\text { publicados no ano anterior }\end{array}$ \\
\hline Número do registro da empresa & Cargo & \\
\hline Representante legal & Telefone & \\
\hline E-mail &
\end{tabular}

* CUIT, PIVA, Federal Tax Identification Number, etc.

\section{Dados da publicação (dados editoriais sobre o projeto de tradução e publicação)}

\begin{tabular}{|l|l|l|}
\hline $\begin{array}{l}\text { Tipo de publicação } \\
\text { ( ) Impressa }\end{array}$ & Formato (em cm) & Número de páginas \\
\hline ( ) Impressa e digital & & \\
\hline Data de publicação estimada & Preço estimado & Tiragem da edição impressa \\
( ) Bcabamento do livro impresso & Tipo de papel da obra impressa & Área de distribuição \\
( ) Capa dura & & \\
( ) Livro de bolso & & \\
( ) Outro & & \\
Qual? & & \\
\hline
\end{tabular}




\section{Informações adicionais}

1. O tradutor solicitante já recebeu outras bolsas/subsídios/incentivos de outras instituições, públicas ou privadas, brasileiras ou internacionais para a tradução do livro indicado nesta inscrição?

( ) Não.

( ) Sim. Qual?

2. Como conheceu o Programa de Residência de Tradutores Estrangeiros no Brasil?

( ) Agentes Literários

( ) Autores

( ) Editoras

( ) Tradutores

( ) Feira de Livro e/ou Evento de Literatura. Qual?

( ) Outros. Especifique:

\section{Declaração}

\section{À FUNDAÇÃO BIBLIOTECA NACIONAL,}

$\mathrm{Eu}$, , venho requerer a inscrição da obra acima citada no Programa de Residência de Tradutores Estrangeiros no Brasil.

Declaro para os devidos efeitos, sob as penas da lei brasileira, que as informações por mim prestadas constituem fiel expressão da verdade, e que aceito as normas descritas no Edital do referido Programa.

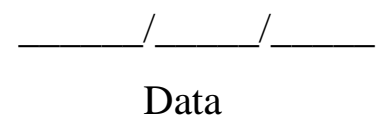

Assinatura do(a) tradutor(a) 


\section{Programa de Residência de Tradutores Estrangeiros no Brasil Anexo II - Comprovação da cessão dos direitos autorais patrimoniais de obra \\ (Preenchimento por parte do representante legal da editora estrangeira)}

Declaro, na qualidade de representante legal da Editora situada em , ser ela titular dos direitos autorais patrimoniais, para fins de tradução e posterior publicação em língua da obra original publicada em português no Brasil, com o título:

de

Autoria

de , de acordo com o instrumento legal efetivado com Autor e/ou seu representante legal, cuja cópia segue em anexo. Declaramos, ainda, que a mesma possui contrato de tradução, cuja cópia segue em anexo, devidamente legalizado com $\operatorname{Sr}(\mathrm{a})$ : , que executará o serviço de tradução.
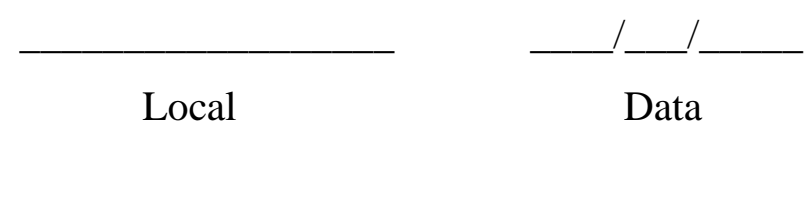

Representante legal da editora (assinatura e carimbo) 


\section{Programa de Residência de Tradutores Estrangeiros no Brasil Anexo III - Descrição das atividades previstas}

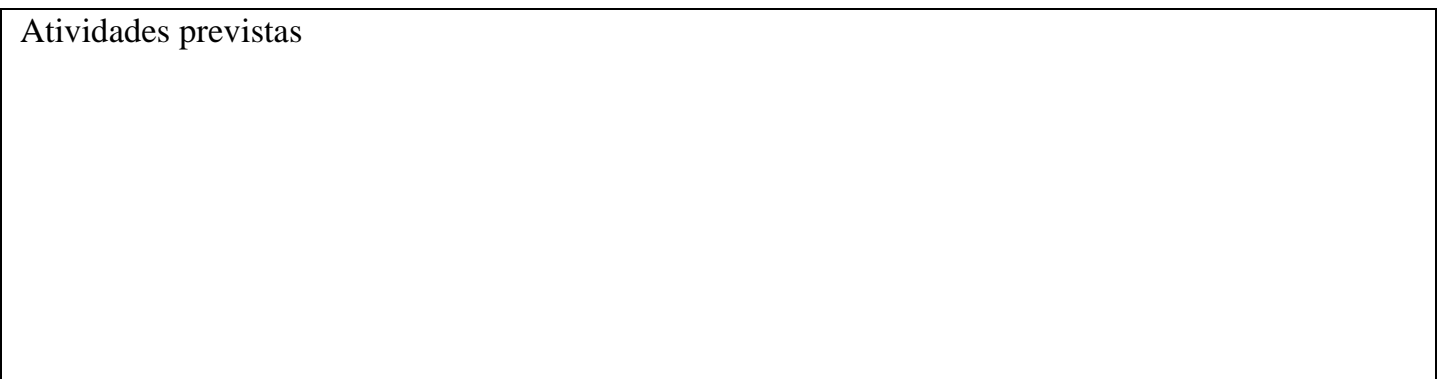

Assinatura do(a) tradutor(a) 